

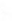





THE AGE OF JUSTINIAN AND THEODORA 
LONDON : GEURGE BELL AND SONS PORTUGAL ST. LINCOLN'S INX, W.C. CAMBRHDE : DEIGHTON, BELL \& CO. NEW JOKK: THE MACMILLAN CO.

bOMIAY: A. H. WHEELEK \& CO. 


\section{THE AGE OF JUSTINIAN}

\section{AND THEODORA}

A HISTORY OF THE SIXTH CENTURY A.D.

BY

WILLIAM GORDON HOLMES

VOL. II

LONDON

GEORGE BELL AND SONS

1907 


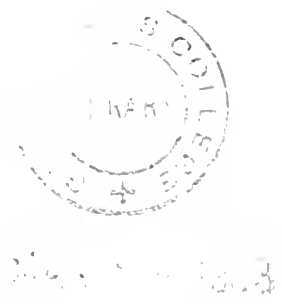

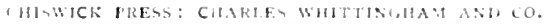
TOUKS COLRT, CHULARY LINE, LUNGM, 


\section{CONTENTS}

PAGF

Chap. V. The Persians and Justinian's First War with them. . . . . . . 365

VI. The Schools of Philosophy at Athens and their Abolition by Justinian . 420 ViI. The Internal Administration of the

Empire: Insurrection of the Circus Factions in the Capital . . . 440

VIII. Carthage under the Romans: ReCOVEry of Africa From tile Vandals 489 IX. The Bullding of St. Sophia: The Architectural Work of Justinian .

X. Rome in the Sixth Century: IVar with the Goths in Italy . . . . . 544 XI. The Second Persian War: Fall of Antioch: Military Operations in LAZICA . . . . . . . . . $55_{4}$

XiI. Private Life in the Imperial Circle and its Dependencies . . . . . 605

XiII. The Final Conguest of Italy and its Annexation to the Empire • . 624

XiV. Religion in the Sixth Century: Justinian as a Theologian . . . 668

XV. Peculiarities of Ronian Law: The Legislation of JUstinian . . . . 706 
vi

Chap. XVi. The Last Days of Justinian: LiteraTURE AND ARt IN the Sixth Century: Summary ani Review of the Reigy 726

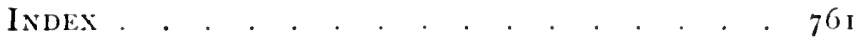

\section{MAPS}

Seat of Justinian's Wars in the East . . . . 396 Seat of Justisian's Wars in tile West . . . 572 


\section{THE AGE OF JUSTINIAN AND THEODORA}

\section{CHAPTER V}

THE PERSIANS AND JUSTINIAN'S FIRST WAR IVITH THEN

( $\mathrm{N}$ the death of Justin the absolute control of the Empire became centred in the hands of Justinian. Nine years of virtual sovereignty during the lifetime of his uncle had familiarized him with Imperial procedure, and nullified the infuence of a bureaucracy which might aspire to govern vicariously by taking advantage of his ignorance of affairs. His tutors in the art of autocracy were dead or superannuated, and his present subordinates owed their elevation to his favour and judgment. The new Emperor was a man of middle stature, spare rather than stout, and on the verge of becoming bald and gray. His features were sufficiently regular, his face was round, his complexion florid, and he wore neither beard nor moustache. 'Those

1 The minute description of Justinian's personal appearance is due to Procopius (Anecd., 8), and Malala (xviii, p. 425), whose descriptions seem to correspond fairly. There are several representations of Justinian, but it is doubtful whether any of them rise to actual portraiture. Those found on a large gold medal formerly in a museum at Paris (stolen 1835 )

11.

B P 
whom he impressed unfavourably were fond of pointing out that he bore a striking resemblance to Domitian.' He affected a pleasant demeanour, appeared always with a set smile," and was so studious of personal popularity that even the meanest of his subjects might hope for an audience of his sovereign. With an unbounded belief in his own capacity for discrimination, he was always ready to listen, but never to be convinced. His assurance communicated itself to those with whom he came in contact, and his associates rarely ventured to dispute his opinions. ${ }^{3}$ His mode of life

were probally the hest (reproduced by Isambert, of. cit.; Diehl, of. cit., 1. 23). He appears in the great mosaics at Kavenna (see P. 91), and also in a half-length figure in St. Apollinare of the same town. Further

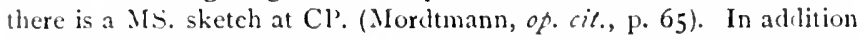
there is the current coinage, especially the copper, on which his image is impressed. Generally the face is pronouncedly round, but, one and all, these likenesses are too crude to convey any physiognomical information. See also p. 30 S.

2 Procopius, Anecd., 8. He relates that after the butchery of Domitian all his statues were broken to pieces, hut his wife afterwards fitted the fragments of his body tngether and caused a new figure to be sculptured from them. There is an almost perfect statue of Domitian in the Valican, which may lie the one he alludes to, if there is any truth in his story.

2 Jn. Malala, xviii, p. 425; Chron. Paschal, an. 566. "You would have taken him for a man with the mind of a sheep," says Procopius, Anecd., I3.

${ }^{3}$ His character and manners can be collected from Procopius (Anecd., $6,8,10,13,15,22$, etc.) and Zonaras, xiv, 8. Ilis personal influence is well illustrated by the incidenialready related (p. 303) of his rescuing a patrician from the mol, although at the time he was only a Candidate; and by his deliberate misallinnce with Theodora being permitted with. out a murmur from Church or State. Ilis stolid conriction may be com. pared to that of Robespierre, of whom, when he first began to speat on public affairs, Mirabeau remarked, "That young man will go far; he lelieves cvery word he says." 
tended strongly towards asceticism, and he yielded no indulgence to his natural appetites. In his diet he restricted himself to the barest necessaries, he seemed to exist almost without sleep, and there is no evidence that he was ever attracted sexually by any woman except Theodora. Without commanding abilities, his mental activity was incessant, and he was perpetually busy in every department of the state. He plunged into politics, law, and theology, with the conviction that he could master every detail and deal effectively with all questions which might arise for deeision. Yet he was credulous and lent a willing ear to those who brought in doubtful reports, which he was generally prone to act upon without due inquiry as to their authenticity. ${ }^{2}$

The Empress Theodora, ${ }^{3}$ after her elevation, still presented in most aspects of her life and character a marked contrast to Justinian. She was devoted to the care of her person, and a great part of each day was given over to the mysteries of her toilet. She trusted especially to sleep for the preservation of her beauty, and passed an excessive number of hours, both day and night, upon her couch. Gratification of the senses absorbed most of her time, and

1 Procopius, Anecd., 8; 13. In many of his enactments he emphasizes his unremitting assiduity in the interest of his subjects, e.g.: "We shun no difficulties, continually watching, fasting, and labouring for our subjects, even beyond what can be borne by the human frame"; Nor. $\mathrm{xxx}, \mathrm{I}$; ; cf. viii, $\not f . ; 1 \mathrm{xxx}, \not f .$, etc.

2 Procopius, Anecd., 22. "He was excessively senseless and like a dull ass that follows whoever holls the bridle," ibid., 8. "As to his opinions he was lighter than dust, and at the mercy of those who wished to urge him to one side or the other," ibid., 13.

3 There is but one representation of Theodora, that in the companion mosaic to the one above-mentioned at Ravenna, but the face is too unfinished and expressionless to give any idea of her features or character.

+ Procopius, Anecd., I2. 
she indulged herself in the luxury of a table always spread with the rarest delicacies. The air of the city was uncongenial to her, and she resided during the greater part of the year at the Heraion, ${ }^{1}$ a palace over against the capital on the Isiatic shore of the Bosphorus, where a second centre of Imperial state was maintained for her benefit with lavish magnificence. But she was ever vigilant in preserving the closest relationship with the machinery of government, and in her retirement she meditated persistently on the exigencies of the autocracy. Her numerous emissaries were to be observed continually passing and repassing the strait which separated the Heraion from Constantinople, regardless of tempestuous weather, and eren of a ferocious whale which had long infested the vicinity and made a practice of attacking the small craft sailing in those waters, often with fatal result to the occupants. ${ }^{2}$ The personal relations of the royal partners during the whole course of their joint reign, continued to be of the most intimate description. Justinian not only deferred habitually to the judgment of his consort, but took every opportunity of making a public profession of his indebtedness to her co-operation. In Imperial acts and edicts she appeared constantly as the "revered wife whom God had granted to him as the participator of his counsels." ${ }^{3}$

1 Procopius, Anecd., 15.

'Procopius, Anecd., 15. This Porphytio, such was the popular name bestowed on the monster, must have been a cachalot or sperm whale, which inhalits tropical and sub-tropical seas. It grows to a lenglh of 50 or 60 feet. The males fight vicionsly among themselves. Small ships have leen damaged by the animal when provoked by an attack.

Nor. viii, r. Officials, on laking office, had to swear w Juslinian and Theertora conjointly; ithd., jusjur.; of. Nor. xxvii, 5 ; xxix, a; $x \times x, 6,11$. \%onaras remarks, "In the time of Justinian there was not a monarchy, but a dual reign. Itis partner for life was nol less poltent, 


\section{The Persians and Justinian's First War 369}

It may, indeed, be assumed as certain that the resolution and verve to be found in the character of Theodora supplied some real deficiencies in the imperturbable and less acute nature of her husband; ${ }^{1}$ and Justinian was well inclined to justify his extraordinary marriage by insisting that exceptional advantages accrued to the state from his choice of so able a consort. Although the spectacle of a Roman empress electing to lead the life of a prostitute was almost a familiar one in previous history, ${ }^{2}$ that an actual courtesan should be raised to the throne, was a unique event in the annals of the empire. Nor was Theodora at all exercised to veil her ascendancy in the affairs of government; on the contrary, she scarcely refrained from proclaiming publicly that her will was predominant in the work of the administration." $^{3}$ Her pretensions were generally allowed, and those who sought preferment through Court influence regularly crowded her ante-chamber, with the assurance that success depended on winning her favourable regard. Unlike Justinian, Theodora made herself difficult of access, and an assiduous attendance for many days was an indispensable preliminary to obtaining an audience of the Empress. ${ }^{*}$ Doubtless but a small portion of each day could be spared from the seclusion she imposed on herself for the nurture and elaboration of her person. Is both Emperor and Empress by an un-hoped for chance had leaped to the Imperial seat from the obscurity of plebeian life, they were

perhaps even more so than himself," xiv, 6; cf. Paul Silent., i, 62. The reign has been compared to that of Louis XIV; but the character of that monarch was more evident in Theodora than in her husband.

1 "In fact she was much abler than he was and highly ingenious in finding new and varied expedients." Zonaras, loc. cit.

2 As Messalina, the elder Faustina, Soaemias, etc. ; see chap. iv.

${ }^{3}$ Procopius, Anecd., 2.

+ Ibid, 15 . 


\section{The Age of Justinian and Theodora}

proportionately jualous of their authority in the lofty position to which they had attained without the qualifications of rank or lineage. Hence they exacted the most servile respect from all who approached them, and emphasized more than at any former time humility of speech and abject prostration in the presence of the sovereign. Any subject, without the exception of patricians or even of foreign ambassadors, on arriving at the foot of the throne was compelled to extend himself on the ground with his face to the floor and then to kiss both feet of the monarch before he was privileged to deliver his message or to make a request." On such occasions the titles of "emperor" and "empress," as expressing a merely official hegemony, were considered to be insufficient, and it was expected that, by substituting the terms "master" and "mistress," the subject should confess himself to be the actual slave of his sovereign." In previous reigns the forms of adoration had been reserved for the Emperor, but Theodora ignored such precedents and claimed for herself all the homage due to an independent potentate. In one respect only did the conjugal harmony of the Imperial couple appear to be seriously disturbed; while Justinian was strictly orthodox in religion, Theodora gave an uncompromising support to the Monophysites. 'The public, however, refused to believe in the reality of this dissension, and attributed the seeming discord to an astute policy which obliged the conflicting sects to give their united support to the throne. ${ }^{3}$

The war with Persia, which had dereloped in a desultory fashion under Justin, began to be waged with determination at the outset of Justinian's reign. A thousand years before

\footnotetext{
I'rocopius, Anecil, jo.

Jhid., 10; Evagrius, iv, 10; Victor Ton. 
this date the Persian Empire, founded by Cyrus the Achaemenian, had reached from the frontiers of India to the shores of the Mediterranean, and had even held Egypt precariously as an integral province. Diverse nationalities marched under her standard, and immense hosts of Asiatics were habitually mustered for the achievement of foreign conquest. But this monarchy proved to be short-lived, and was destroyed in less than two centuries, after the invasion of Greece by Darius and Xerxes had disclosed the fact that a few thousands of patriotic Hellenes were of more martial worth than the vast and heterogeneous armies led by the Persian king. Less than ten years of actual warfare sufficed to bring the Achaemenian Empire and its dependencies under the rule of Alexander; and the indigenous races were kept in subjection by the Graeco-Macedonian invaders for a longer period than the kindred dynasty established by Cyrus had endured. The Persian Empire, in its widest extent, as it existed under the Ichaemenidae, was never restored; nor did any subsequent conqueror issue from the west to repeat the exploits of Alexander. The Asiatic successors of that monarch, the Seleucidae, ${ }^{1}$ were gradually ousted from their dominions by a wild race which attacked them from the north, and became known historically as the Parthians. Under their native rulers, the Arsacidae, they might have restored the empire of Cyrus, but the simultaneous growth of the Latin power in Asia Minor and Syria for ever confined the Parthians to the eastern bank of the Euphrates. The policy of Rome, as defined by Augustus, forbade the extension of the empire beyond the limits assigned to it after the battle of Actium; but at least one emperor, the indomitable Trajan, was ambitious of emulating the prowess of Alexander

1 See Bevan's House of Seleucus, Lond., 1902. 


\section{The Age of Iustimian and Thiodora}

and designed to advance on India. Nithough not uniformly victorious, he transformed the kingdom of Armenia into a Roman province, and almost reduced Parthia to the condition of a vassal state.' 1)ath, or the more pressing claims of home affairs, imposed a term to his activity in the field, and his great schemes of conquest were never again entertained; but several later emperors, notably Severus, (arus, and Galerius, often demonstrated the superiority of the Roman forces under competent generalship over their Oriental antagonists." But after the Gracco-Roman supremacy had declined to the stagnant mediocrity of Byzantinism this ascendancy could no longer be maintained; and as often as East and West came into collision the honours of war almost invariably rested with the Asiatic power.

For more than five centuries after the overthrow of Darius by the armies of Macedon the remmants of the Persian race languished in the Province of Persis, a small statc lying east of the Persian Gulf, to which was allowed a semi-independence by the supreme government. Here was the original home of Cyrus, and here be matured his plans

1 The campaigns of Trajan are very imperfectly recorded in the only' extant account, that of Dion Cassius as preserved in the careless epitome of Xiphilinus; Zonaras, $x i, 21$. It is certain that he tonk the twin capitals of Parthia, Seleucia and Clesiphon, which faced cach other from oppoile sicles of the Euphrales, and advancel to the Pervian Gulf. Ite marclect into Arabia, but the evidence that he penetrated to the Indian Ocean, as Tillemont thinks, is insufticient.

"The capture of Seleucia ly Avidius Cassius (165), and his lrutal massacre of 300,000 of its inhabitants, mostly Greeks, is often allurled to as an irreparable blow to Weatern civilization in the Eas: I)ion Cas., Ixxi, 2, etc. Severus took Ctesiphon in 199; Herodian: Hist. August. In $2 \$ 3$ Carus also took Cresiphon; Ilist. August.; Aurelius Vict. Under Discletian, (ialerius extended the Empire heyond the Tigris; Aurel. Vict.; Lutropius, ix. 
for the conquest of Media. From thence was derived the name of Persia, which was applied by the western nations to the whole land of Iran, the native appellation of the extensive plateau ranging from the Hindu Kush to the river Tigris. In Persis was situated Persepolis, the traditional capital of the Persians, where the sacred fires of the Zoroastrians was kept perpetually alight in a temple by the Magi. In a drunken freak, or perhaps as a signal to all Asia that he had succeeded to the sovreignty of Iran, the ancient city had been committed to the flames by Alexander; ${ }^{1}$ but eventually a capital was reinstated on the old site, and in later centuries became known as Istakhr. ${ }^{2}$ About 200 A.D. a reawakening of Persian aspirations became apparent, and a new Cyrus arose at Istakhr to lead his nation to the reconquest of their former empire. Ardeshír was the grandson of Sásán, who by a fortunate marriage had united the pre-eminence of the priestly caste with that of the princely house of Persis. Having gained possession of the local throne by his superior energy, he began to exercise himself in active warfare by attacking the neighbouring states, whose princes, like himself, were the vassals of the Parthian king. At first his operations were disregarded, and not until he had made himself the lord of a considerable territory was he summoned by his suzerain to explain his encroachments. His reply was a defiance and a challenge to battle. In the war which ensued Artabanus was overthrown by Ardeshir, and the Parthian dynasty of the Arsacidae was replaced by that of the Sassanidae (c.227).

1 See Plutarch's account of the affair and his general remarks on it; Vit. Alex.

${ }^{2}$ In the vicinity of Shiraz; described by modern travellers as a garden of fertility. 


\section{The Age of Justinian and Theodora}

The Persian now assumed the title of Shahinshah, that is "King of Kings," which had usually been affected by the potentates of all Iran, and established himself at the Parthian caputal of Ctesiphon on the Tigris, a position more suitable for the seat of government than the remote Persepolis. The empire thus regenerated by the Sassanians, held its own among the surrounding powers for four hundred years, until the general irruption over Asia of the fanatical hosts of Islam.'

The dominions of Ardeshir and his successors covered an area almost equal to that of the Eastern Empire, but were probably much less populous. 'The table-land of Iran is far from being so well adapted for the sustentation of animal and vegetable life as the countries amalgamated into a single state by the Roman arms. More than a fourth of the surface is occupied by desert and salt swamps; "while the greater portion of the remainder is broken up by immense mountain ranges, some of which rise to a height of I 8 , ooo feet. The prevailing population of this region within the historic period has always been a division of the Iryan race, of the great Indo-Germanic family of mankind, who at some early epoch spread themselves across two continents, from the frontiers of Burmah to the Atlantic seaboard

Mont information as to the rine, etc., of Ardeshir (Artakhshathr on coins, that is, Artaxerxes as alapted to their language by the Grectis), will be found in Tahari with Noldeke's commentary; op. it.: of. zotenlecrg, of. cit., ii, 4o. The great value of Noldeke's beok consiots not so much in the thimsy text as in his notes and excursuses which bring lonether all collateral information to be found in other writers of the perind. Zotenlerg's version is, of course, from the l'ersian, the Iranslatirn of a translation.

- The Greal Salt Desert in the interior of l'ersia is somewhat triangutar, each of the sides measuring alxout 400 miles. 


\section{The Persians and Justinian's First War 375}

of Europe. Originally the possessors of a common language, the elements of their speech are to be found in the Sanskrit, once colloquial throughout the valley of the Ganges, and in the Erse of the Irish peasant, who inhabits the wilds of Connemara. Although the face of the country has been scarred by the march of numerous invaders, and even by religious revolution, the sociological condition of these Eastern lands has scarcely changed at all during the millenniums of recorded history; and the Persian citizen or rustic of to-day is almost a counterpart of those who looked out on the progresses of Darius and Ferxes. ${ }^{2}$ The primitive Iranians were an agricultural people, and as such showed an attachment to the cattle which composed their farm stock almost amounting to veneration. But the tiller of the soil in Iran was often exposed to harsh conditions in the effort to draw his livelihood from the ground. The land was not uniformly fertile, climatic severity not seldom hampered the labourer, and predatory bands of nomads, who raided the country from the north, were a frequent cause of disaster. ${ }^{2}$ Life was a series of vicissitudes, circumstances of time and place were in general sharply contrasted, and the normal activities of nature seemed to the peaceful native to be the outcome of perpetual strife between spirits of good and evil. In Bactria, the north-eastern tract of

1 Modern Orientalists are of opinion that the pictures of Persian life given by James Morier (Hajji Baba of Ispahan, 1824, etc.) may be applied without much loss of truth even to the age of the Achaemenians. When we reflect that till I 888 Persia had no railway, and now only eight miles, the verisimilitude of the statement will be apparent.

2 See the first Fargard of the Vendidad where the "Kine's soul," representing mankind, bewails her hard lot before the supreme being. Generally the primitive conditions of life in Iran are well set forth by Max Duncker, Hist. of Antiquity, Lond. 1881, vol. v. 


\section{The Age of Justinian and Thiodora}

Iran, all these conditions were most typically presented. Ibout 1000 13.c. that region was ruled by King Vistaspa,' under whom flourished the prophet Zarathushtra, the original redactor of the religion and ethical system accepted by the Persians. He gave a distinct expression to the philosophical tendencies of his age, and refined the loose polytheistic conceptions at first held by the Iryans to the complete dualism in which Ahura-Mazda, the Lord of Wisdom, and Ingra-Mainyu, the Devisor of Evil, became the essential factors of a definite theological faith. ${ }^{2}$ On this foundation an . Mresta or Bible of Mazdeism was elaborated, which laid down the law for the whole conduct of human life. ${ }^{3}$ Among the primitive deities most reverence had been

'His actial date is unknown, and his existence at any time not certain, but Juncker surmises this period.

2 The Iranian mythology is summarized at length by Duncker, but the person of Zoroaster is allogether shadowy, and his date can only be fixed by conjecture. IIe is, of course, done away with altogether by some Orientalists, c.g. Darmsteter. In later times, as among the modern l'ersians (l'arsees), the names of the opposing gods were abbreviated to Ormuzd and Ahriman.

3 The Pursian Bible is written in a langunge without a name, and, it may be added, without an alphabctical character. The name Zind, however, is now firmly attachel to it among Wentern scholars through a mistake of the first investigators, who, always finding it coupled with Aiesta, thought it must apply to the language of the sacred text. It aetually means commentary. Zend is a sister tongue of that spoken in the same age across the Indus, and the videst specimens (the Gathas of the Avesta) by slight systematic alterations can be turned inle good old Sankirit. The alphabet applicel to it, as now preserved, is that of the Niddle l'ersian or l'ahlavi, which was the language spoken by the sassanians. Old l'ersian, the speech of Darius and Aeract, was wrillen in cunciform (Behistun inscription, etc.), like the impressions on the " chl. limewn clay talslets, etc., of the long previous literalure of l3alylemia. The dresta originally comsisted of a wenly-one nask or luoks, lut les than a quarter is now extant. There is, however, an ejpitome of it in the 


\section{The Persians and Justinian's First IVar}

paid to Mithra, the sun-god, to Spenta Aramaiti, the earth spirit, and to Anahita, the goddess of the waters. ${ }^{1}$ As subordinates of Ahura-Mazda, these divinities still held an established place, and were made the immediate objects of the rites and ceremonies imposed on the pious Iranian. Hence the sanctity of fire, earth, and water became an article of faith, and it was believed to be a heinous crime to contaminate them with any impurity. Whaterer was evil was esteemed to be impure, and, therefore, the work of Angra-Mainyu. The Druj Nasu, a female demon, personifying the lie, was regarded as his universal agent, and as being present imminently under all adverse circumstances. Such were the principles of Mazdeism, the rigid application of which, and they were rigidly applied by the Magi, was productive of many curious sociological phenomena strangely at variance with the customs of other nations. ${ }^{2}$ Death was

Dinkard, a religious compilation of the eighth century. The book was unknown to the Greeks and Romans, but Pausanias (v, 27) mentions that the Magi had a volume from which they read. Darmsteter (Sacred Books of the East, Lond., I S95, Introd. to Vendidâd) consirlers that the composition is almost in its entirety of a date subsequent to Alexan. der. The sacred books of the Parsees, as far as they have been translated, are to be found in Max Miuller's series (Lond., I8So, etc.), just mentioned, vols. iv, xxiii, xxxi (Zend-Avesta), and $\mathrm{v}$, xviii, xxiv, xxxviii (religious treatises in Pahlavi).

1 Mithra, so-named, long enjoyed a supremacy among the Aryans both in India and Persia. Spenta Aramaiti is one of the Amesha Spentas (later Amshaspands, that is, "Holy Immortals," or Council of Ormuzd, but, although they appear in the Avesta, Darmsteter (Ioc. cit.) argues a Platonic and, therefore, late origin for them. Thus Vohu Manô ("Good Thought"), their chief and the premier of Ormuzd, appears to be an exact counterpart of the Philonic Logos. Anahita stands for the Vedic Varuna, the waters of the sky, but the name is that of the Babylonian Venus, and her attributes are partly of the concupiscent type.

2 The Vendidâd ("laws against the evil nnes") is the nask which 


\section{The Age of Justinian and Theodora}

considered to be the greatest of calamities, and hence a corpse became possessed of the Druj, and the most active of all sources of contamination. That so foul an object should be placed in intimate contact with the holy elements of fire, earth, or water, was sacrilege in the highest degree. Cremation and burial were, therefore, held in abhorrence, and a deceased person had to be borne to some isolated spot, far from fire and water, there to be exposed on an elevated bier with the intention that the flesh should be devoured ly wild dogs, birds, etc.' I)isease was, of course, a grade of demoniacal obsession, so that sympathy for the sick was almost alienated by superstition. If an ordinary' soldier were taken ill on the march he was abandoned by the wayside, some provisions being left with him, and also a stick, with which to beat off any carnivorous animals. Should he recover, on his reappearance all fled from him as from an apparition risen out of the infernal regions; nor could he resume intercourse with his relations until he had undergone a rigorous purification by the Magi. ${ }^{2}$ Owing to the holiness of water great reverence was felt for rivers, which were protected by law frem all defilement ; and no good Zoroastrian would travel by ship lest he should pollute the sea with his normal excrement. ${ }^{3}$ For purposes of cleansing

contains all the legislation respecting rites and ceremonies, offences, crimes, etc., punishments to be inflicted, means of expiation, etc. Like parts of the I'entateuch, it is all in the form of a dialogue between the frophet and the Deity.

These Dakhmas, or "Towers of Silence," for the disposal of the dead are well-known to the Anglo. Indians who have resided at Bombay, which almost all I'arsees, the present-day Zoroastrinns, have adopted as their native city. 'They' number about 60,000.

- Thi acerunt is due to Agathias, ii, 23 ; cf. Herculotus, i, 138 .

Agathias, ii, 24; llerololus, loc. cit. Contıary lo former helief 


\section{The Persians and Justinian's First IVar}

water was used very charily, and it was sinful to take a bath. The vegetable productions of the earth were viewed with profound admiration, wherefore the cultivation of gardens and parks was among the greatest delights of the Persians. The estimation in which cattle were held was the cause of some singular legislation and ritual enactments. Thus the urine of the cow was habitually collected and made use of daily for the purification of the body by washing. ${ }^{3}$ The sheep-dog was an object of extreme solicitude, so much so that the penalty exacted for manslaughter was only half as onerous as that inflicted for the crime of giving bad food to such a precious animal, ${ }^{4}$ but even the latter was a mild offence compared with the infamy of killing a water-dog, the name by which the otter was identified, as the wretch convicted was sentenced to be beaten to death. ${ }^{5}$ On the other hand, noxious animals were regarded as the creation of Angra-Mainyu, and the Magi made it a religious duty to kill them with their own hands, especially ants, serpents,

(Rawlinson, etc.), the Farthians were pious Mazdeites, as Darmsteter has shown. Thus, when Tiridates visited Nero, he and his retinue, including several priests, journeyed overland to avoid defiling the sea; Justin, xli ; Pliny, Hist. Nat., xxx, I7.

${ }^{1}$ One Shah, Balâsh, was, in fact, dethroned by the Mohbeds (Magi) for having erected public bath-houses; Jos. Stylites, op. cit. (Wright).

${ }^{2}$ Xenophon, Oeconom., iv, 13 ; Xerxes, on his way to Greece, arriving at a handsome plane tree, adorned it with jewels of gold, and left one of his personal guards as a custodian of it; Herodotus, vii, $3 \mathbf{I}$.

${ }^{3}$ The Bareshnum, or great ceremony of purification, lasted nine days and consisted chiefly in the systematic application of nirung or gome (urine of kine) to different parts of the body; see West's translation of the rubric, Sacr. Bks. of the East, xviii, 43I.

${ }^{4}$ Vendidâd, xiii, $24(63)$. The manslaughterer got off with sixty stripes, but the bad feeder became a peshotanu and received two hundred, the maximum, it seems, actually inflicted.

${ }^{5}$ Ibid., xiv, 1; iv, 40 (106). 


\section{${ }_{3}$ So The Age of Justinian and Theodora}

reptiles in general, and certain birds. ' In some cases it was permitted to the subject to take the law into his own hands and to slay the guilty person on the spot. Such culprits were the highwayman, the sodomite, the prostitute, and anyone caught in the act of burning a corpse." On the whole, however, capital punishment was infrepuent, and ahmost any trespass, even murder, could be atoned for by making a money payment to the Magi."

In the sociology of Mazdeism the strangest phenomenon that developed itself was the tenet that affinity by blood was the highest requisite in a marriage contract. This principle was inculcated by the priests to an extrene degree, so that the closer the relationship the more acceptable was the union affirmed to be in the eyes of the Deity. Not only could brother and sister marry under religious sanction, but

'Vendidad, xir, 5 (9). I'art of the expiation for the murder of an otler was to kill ro, ooo of every sort of noxions animal. The punishments, or tasks imposed in lieu of, are sometimes so extravagant, that they can only be intended to emphacize the heinouness of the sin, a useful prin. ciple to elevate the authority ut the prienthood; cf. Iterodotus, i, 140.

2 Vendilàl, viii, 26 (74); 7+ (233); xviii, 61 (123); cf. iii, iS (130); $\mathrm{ir}, 47(1,0)$. As will be seen from these passages a proselyte w .lazeleism legan a new life with a clean slate. Thus a member of an alien faith could commule the screres penalty by announcing himself as a convert t) the religion of \%erdusht.

${ }^{3}$ Vendidad, xiv, 2 ; cf. Ilerodolus, i, I 37 ; vii, 194. I'unishment was inflicted with a sraosha (son of whip), and each stripe was valued at six rupees. In practice the maximum was 200 stripes for a festotann or culprit of the worst class, whalever lase nature of the crime, lut when it was really meant to decree the death penalty the allotled number was much greater, even up to 10,000; see I larmsteler, of. cif., l'. hxxv. In the entourage of the monarch, however, the same cruel puninhments "ere maintained as have always been associaled with Gricutal despution, viz, flaging alive (Ammianus, xaii, 6; Agathias, is, 23), and exen "the

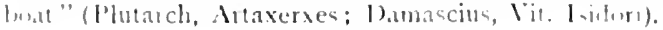




\section{The Persians and Justinian's First War $38 \mathrm{I}$}

even father and daughter ${ }^{1}$ and, most repugnant of all to the common inclinations of humanity, the nuptials of mother and son were expressly enjoined as a righteous act by the Avesta. This anomalous association of the sexes was justified partly by the false analogy of certain physiological facts supplied by the animal kingdom, and partly by an appeal to precedents to be found in the Iranian mythology. Hybrids were notoriously infertile, and the congress of horses with asses engendered mules who were impotent to propagate their kind. Hence the mingling of family blood was indicated as essential to preserving the integrity of the race. Further, it was pointed out that the primaeval man, Gaya Maretan, impregnated Spenta Aramaiti; that is, his mother earth, the result of this conjunction being a son and a daughter. By this union the brother and sister became the progenitors of the whole human race. At least one Parthian, and probably several of the Achaemenian and Sassanian kings, may be noted as having chosen their own mother for their consort on the throne. ${ }^{2}$ Such marriages were not merely ceremonial, although in some instances the chief inducement may have been to insure the support of the Magi for a disputed succession. ${ }^{3}$ Incestuous offspring were

1 See Herodotus, iii, SI; Plutarch, Artaxerxes.

${ }^{2}$ Phraates V of Parthia. His mother was Thea Urania Musa, an Italian slave girl presented to his father by Augustus; Josephus, Antiq., xviii, 2. The relations of Parysatis to Artaxerxes and of Sisygambis to Darius Cod. were very close, but are not known to have been actually conjugal.

3 These filio-maternal marriages have been generally discredited by modem historians (Rawlinson, Oriental Monarchies, ii, $35^{1}$; even partly by Max Duncker, op. cit., v, 220) through their not being in possession of all the classical evidence and having apparently none of the Oriental. Probably the first to make the practice known in the West was Quintus Curtius, and lastly Agathias. But the evidence of Chrysostom alone, a II.

C C 


\section{jडs The Age of Justinan and Thiodora}

\section{not unknown, and the case of Sisimithres, a provincial}

potentate subdued by Alexander, is specially mentioned as

Syrian reared on the borders of l'ersia, would be conclusive. As usual, he andtomizes the subject. Preaching against sexual abanclonment, he says: "Love, you maintain, is not a matter of will. . . Whence does it arise, then? From a beautiful form which strikes the wound, you answer. Your excuse is an idle one. . . Were not Joseph and barid handsome, the latter especially so in the eyes, which is the most altraclive style of heauty? But was any man cnamoured of them? by no means, for love dues not arise from mere admiration. Many have mothers most distingrished for their beanty, lut do their sons, therefore, fall in luve with them? J'erish the thought! They admire them, but do not yield to a disgraceful passion. Ah! you will urge, this is a law of nature. Of what nature, tell me? lecause they are our mothers, you say. Do you not know that the Persians, without any compulsion, cohalit with their mothers? Not one or two, but the whole nation. Whence it is evident that this disease is not incpired ly beanty, hut by' a vice of the mind"; ln Epist. ii ad Cor. Hom. vii, 6 (in Migne, $x$, 451). Contemporary Parsees also wish to repudiate the illea that their forefathers solemnized these incestuous nuptials, and treat it as a libel of the Greeks, as modern Iazdeism yields to no closer union than that of first cousins. The whole question, however, of consanguineous marriage has been threshed ont from the evidence of the Pahlavi texts by Wist (Sacr. liks. of the kast, aviii, 3 S9 et sey.), who shows huw strenuously the Nobbeds laboured to inculcate the practice as a pious duty. A special term in Pahlavi, Kthattikitas, meaning literally "a giving of one's uwn," was applied to it. There is no clear reference to the custom in the extant part of the Aresta, but in the 1)inkard epitome (ix, vo; Sacr. bis. of the East, axxvii) gleat stress is laicl on the merit of atl. hering to it, and in the sume theological compilation a long chapter (iii, $\$ 2,431)$ is devoted to the defence and exposition of Khretikedas. As llest observes, however, it is evilent from the amount of space ant argument expended on the suliject that the pilesthool had some difliculty $m$ bending an unwilling laity to comply with their injunetions. Wie may mote that the l'ersians were not the only race adelicted to such marriages. According (1) Strabo $(I N, \mathbf{N}, 4)$, they were hatitual among the Irish of his time ("mothers and sister,"): and eren the aboliginal Yacediunan, favoured them, so that when the Oedigus lice of Sojhocles wa played on that country the audicace jeced at the distees of the 


\section{The Persians and Justinian's First War $38_{3}$}

that of one whose mother-wife had borne him two sons. ${ }^{1}$ Rich Persians indulged themselves with several wives, besides maintaining numerous concubines, but, as monogamy only was contemplated by the Avesta, the senior wife was the undisputed mistress of the household. ${ }^{2}$

The Parthians found it politic to assimilate their supremacy to that of the Greeks whom they had displaced; and thus to attract to themselves the influence which had so recently been predominant throughout Iran. They, therefore, distinguished themselves by the epithet of "Philhellen," and continued to impress their coins in Greek characters with that affix, even after the Romans had become most potent in the East. By degrees, however, the memory of the Greek dominion faded, and before the middle of the second Christian century orientalism was completely reestablished. Legends in the Pahlavi, or Parthian language, were adopted for the superscription of the currency, upon which the Hellenized Serapis now yielded his place to Mithras or the Mazdean fire-altar. ${ }^{3}$ Is a scion of the house of Sásán, Ardeshír was naturally much swayed by priestly influence, and relied on the support of the Magi as the chief element of his power. By his edicts and inscriptions he proclaimed himself to be a Mazdayasn, or devout servant of Ahura-Mazda, and the dynasty he founded was always noted

titular character. An amusing dialogue between actor and audience then ensued; see Tertullian, Ad Nat., I6.

1 Quintus Curtius, viii, 4 (19).

2Herodotus, iii, 68, 88; Athenaeus, xiii, 3, etc. ; Ammianus, xxiii, 6. As usual in the East, women were kept out of sight; Plutarch, Themistocles. Still, Queen Statira used to drive about openly in public; ibiat, Artaxerxes. Cf. Max Duncker, of. cit., v, 2 Ig.

${ }^{3}$ See Gardner's Parthian Coinage, Lond., I877; cf. Mordtmann, Zeits. f. Numis., iv, vii, 


\section{${ }_{3} S_{4}$ The Age of Justinian and Theodora}

for its tirm adlerence to the national religion.' On his accession Ardeshir undertook the restoration of the $A$ vesta, a great part of which had been neglected or altogether lost, and under the supervision of the Magi he caused a purification or reformation of the faith of Zarathushtra to be begun." This work was continued by his successors, but, as no canon of scripture had been formed, there were many conflicting sects, and not until the reign of Sapor II ${ }^{3}$ (c. 330) was the text of the sacred book fixed beyond dispute. Then Adarbatd, a holy man, produced his recension of the Ivesta among the assembled Magi, and offered to submit himself to the ordeal of fire in proof of its strict orthodoxy. Molten brass was poured upon his breast, he passed the test unscathed, and his reading of the tenets of Mazdeism was never afterwards contested. ${ }^{1}$

1 See the letter of Tansar to the king of Tabaristin (Ilyrcania); Journal asiatique, IS94, i (text and French (ransl.). This, according to Darmsteter, is the earliest and most authentic document of \%oroatrianism. The lust MS. is in the Fast India llouse. From it we learn that uniler the l'arthians the unity of Jran was gradually dissolved into a number of principalitics, in which each king claimed a practical in. dependence and set up a fire-altar of his own. Ardenhir extinguished all these subordinate fire-altars and made himself supreme in his capital of Jotakhr. The letter has been largely interpolated at a luter date, especially by the long apologue of the King of the Apes. Partly against Darmsteter see Mills' Zoroastrianism, 1905, etc.

- lle treated the traditions of the old religrion pretty frecty and alulinhed whatever did not accord with his scleme of retoring the empire of the Persians; ibil.

"l'ruperly Shalpûr, meaning "kingr's sun."

1 See I armsteter, of. cit., p. slvii. The story of Arda Viraf's sisit to hearen and hell (part of the lost Sipend Nask) under the intluence of a narcotic in the presence of a great conventicle of the Magi, in seanch of spiritual guidance for the restoration of Mlazdeism, seems (1) be a mere legend to be referred to the sixth century rather than to the times and 


\section{The Persians and Justinian's First War 385}

Ardeshír did not, however, base his message of fortune solely on an appeal to the mystical emotions of his nation; but he also sought to attach them to himself by stimulating their patriotism. He professed that he would avenge the murder of Darius on the inheritors of Alexander, and asserted himself to be the rightful ruler of all western Isia, which had been unlawfully wrested from his ancestors. Thus the Persian empire, as restored by the Sassanians, was inspired with sentiments which urged it to maintain an inveterate conflict with Rome. ${ }^{1}$

Although there is evidence of constant religious commotion in Persia under the Sassanidae, it does not appear that any considerable number of the historical adherents of Zarathushtra ever swerved from their faith. The numerous priestly tribe of the Magi not only surrounded the throne, but were fully disseminated throughout the provinces as the guardians of Mazdeism. The valley of the Euphrates and Tigris, however, the most densely populated district of the empire, was the site of a very heterogeneous ethnology, with archaeological records which extend backwards for some thousands of years prior to the descent of the Arians into Iran. There had existed the kingdoms of Sumer and . Ikkad, having an ancient mythology of their own, which was liable to be diversified by the infiltration of Semitic elements from

intention of Arcleshir. It has been cited as serious history by some former writers.

${ }^{1}$ Letter of Tansar, ut supra, cf. Herodian, vi, 3. H. is generally treated as a romancer, but in this instance he is confirmed by inde. pendent evidence. IIis statement that Ardeshir had the best of it in a great battle with Alex. Severus is rejected in favour of that of Lampridius (Hist. Aug.), who says the Roman was the victor. The war on this occasion, as often subsequently, was probably quite indecisive. 


\section{${ }_{3} 86$ The Age of Justinian and Theodora}

the south-west.' In this region Mani flourished and was enabled to spread his doctrines, but as soon as be threatened to pervert the loyal Zoroastrians his downfall was brought about by the resentment of the Magi. ${ }^{2}$ Here also Christianity essayed to penetrate into Persia, but with the same result, and we possess some details of the cruel persecution to which Christians were subjected whenever they came into collision with the established religion of the statc. ${ }^{3}$ In some instances, however, Roman heretics, such as the Nestorians who fled before the face of an orthodox Emperor, were accorded an asylum in Persia by a politic Shah.'

Towards the end of the fifth century a serious ferment in the ranks of the Zoroastrians themselves was occasioned by the preaching of a fanatical demagogue named Mazdak. This reformer aimed at nothing less than a subversion of the existing sociological status by the induction of a communistic partage of women and property. All practical class distinctions were thus to be swept away, so that a level affuence should prevail throughout the land. It appears that

'See Sayce's Babylonians, etc., Lond., 1900, and other works of that class which condense the results of the excavations in progress on that site.

2 See p. 267. Fragments of the Nanichaean bible recently discovered in Central Asia show that Mani was a native of Babylon.

${ }^{3}$ Sozomen, ii, 9; Theodoret, v, 39. Some were partly flayed, on the face and the hands, or the back. Others were lhrown bound into pits with mice, etc. The first of these persecutions secms to have sprung from the religious fervour caused by Sapor's zeal for the faith; the secrnd was originated by a fanatical Christian bishop, who allacked and destroyed a l'yreum or Fire-lemple. Sie lloffmann's Akt. Pers. Mirr., I.cipsic, ISSO.

'Aseman, Bill. Orient., iii, 2. They hat the ear of the Shah as against any of the Orthodex in l'ertia; Joln Lph. Com. (Launl, etc.), 1. 52. 
in the early years of his reign Cavades found himself greatly hampered by the arrogant pretensions of his nobles, wherefore he lent a favourable ear to the new propaganda, and gave public encouragement to Mazdak. But the power of the throne was unequal for the achievement of such a revolution; the Magi and the nobles met in council, deposed Cavades, and, with some hesitation conceding to him his life, caused him to be imprisoned in a stronghold called the Castle of Oblivion. From this durance he was shortly released through the devotion of a handsome sister-wife, who seduced the fidelity of the gaoler by the promise of her person. Being allowed to sleep for one night in her brother's apartment, she had him carried out next morning enrolled in her bed-furniture, for the exemption of which from inspection she invented a plausible excuse. ${ }^{1}$ Cavades now made good his escape to Bactria, where he spent a couple of years as a guest of the King of the Hephthalites. Ultimately he obtained the loan of an army from that monarch, ${ }^{2}$

${ }^{1}$ Nöldeke, op. cit., p. I45; Zotenberg, of. cit., ii, I48. They were soiled by her menstrual flux, she said. To touch anything of the kind would have subjected him to a ceremony of purification and, perhaps, a flogging; Vendidâd, xviii, 5. The scene reminds us of that in The Merry Wives of Windsor, where Falstaff is carried out in the foul-clothes basket. Procopius relates that she changed clothes with him, and the Shah walked out disguised as a woman; De Bel. P'ers., i, 6.

2 This was not his first sojourn with the Hephthalites. His father Peroz, who ultimately perished in a battle with these Huns, had left him in Bactria as a hostage for the payment of an indemnity. In Tabari the story goes that on his journey thither he stopped incognito at the house of a noble (N.) or peasant (Z.), where he was accommodated with a daughter of the family as an informal wife. When Balâsh was dethroned (see p. 379), he returned to take up the succession by the same route and found that the girl had become the mother of a boy, the same who was afterwards known as Chosroes, his favourite son (see p. 314). 


\section{$38 S$ The Age of Justinian and Theodora}

with which he drove his brother Jamâsp, who had been created king in the meantime, from the throne. As for Mazdak, it seems that for the next quarter of a century be was allowed a free hand to propagate his opinions, an attitude of neutrality being adopted by the Shah and the Magi. His gospel was accepted by an increasing number of the Iranians, whom he persuaded that his communism was the only mode of life which accorded with the precepts of Zarathushtra. At length the growing transformation of the social system began to be viewed with alarm; a generation of children had sprung up who were ignorant of their parentage, and in all directions the ownership of property was falling into abeyance. ${ }^{1}$ It was resolved, therefore, by the Shah and priests in council that the Mazdakites should be extirpated by the sweeping Oriental device of a general massacre. In order to achieve this object an assemblage of all the members of the sect was convened by Chosroes, the designated heir to the crown, who had ingratiated himself with Mazdak and his disciples under the pretence of being a convert to their doctrines. It was represented that Cavades on a certain day would abdicate in favour of his son, who would at once reinstate the throne on the principle that for the future the Mazdakites should be its chief supporters. The ruse succeeded; Cavades received the leaders in state surromnded by the Magi, asserted his imminent retirement, and desired them to muster their whole following in a place apart.

1 "llence he sel the lower against the upper classes; wrelches of every sort were mingled with the best blood; and it became usual for those who coveted other people's goods 10 seize on them: for the disorderly to riol around; and for libertines to gratify their passions and approach the noblest women, whom previously they never hat a thought of intimacy with": Tahari, p. $15+\left(\mathrm{N}^{\circ}\right)$. This passage with the context is not in Zulenberg. 
There Chosroes would join them and institute the new rigime with due formality. They obeyed, and were immediately surrounded by a division of the army, who cut them to pieces. The remnants of the sect throughout the provinces were afterwards hunted down, and got rid of by burning at the stake. ${ }^{1}$

The moment we turn our attention to the Persian court, and begin to observe the material and ceremonial attributes of the monarch, we discover the prototype of almost the whole fabric of Byzantine state as displayed at Constantinople. In the East was found the model of those accretions which gradually transformed the unassuming Roman Emperor of the Tiber into the haughty autocrat who overawed his subjects with pageantry on the Bosphorus; but the native sobriety of Europe always stopped short of the pronounced extravagance and hyperbole of Orientalism. The throne of the Sassanians stood between four pillars which upheld a ciborium." On sitting down, the Shahinshah inserted his head into the crown, a mass of precious metal and jewels suspended by a chain, too ponderous to be worn without extraneous support. ${ }^{3}$ No epithet was too lofty for

1 The details of this affair are incompletely known. The Greeks seem never to have heard of Mazdak, but confound his followers with the Manichaeans. The above account is based on that of Theophanes, modified so as to accord with Nöldeke's views; op. cit., p. 457 (Excurs.). He thinks the surname of Nushirvan ("the blessed") was bestowed on Chosroes for the part he played in this massacre. Existing Manichaeans were also involved in it.

2 Theophylact. Sim., iv, 7 ; cf. Athenaeus, xii, S.

${ }^{3}$ Nöldeke, op. cit., p. $22 \mathrm{I}$. He was concealed with "clothes" until he settled himself in a dignified position. But in Zotenberg (p. 205) the clothes become merely a covering to keep the dust off the jewels. Such differences are perpetual thronghout the two versions of Tabari. On coins and sculptures the Shah wears a crown surmounted 


\section{The Age of Justinian and Theodora}

the Persian monarch to assume in his epistles; he was brother of the sun and moon, a god among men, and in merely mundane affairs the King of kings, the lord of all mations, as well as everything else expressive of unlimited power and success.' When he made a progress out of doors the streets were cleansed and deconted in the manner already described as customary during the passage of the Eastern Emperor. ${ }^{2}$ Personal reverence was, of course, carried to the extreme point, and even officials of the highest rank kissed the ground before renturing to address the Shah." 'The succession to the throne was strictly hereditary and, although several revolutions occurred during the four

hy a pedunculated ball of consideralle size. At the siege of Amida (359) Sapor wore a golden ram's head insted of a crown; Ammianus, xix, 1. Theophylactus (who is noted for his turgidity) gives a rescrip. lion of llormilz If sitting in state on his throme (590). "Hle was clad with a regal robe of precious material. lits liara of gold and jewels was lutilliant with the effulgence of carluncles. A profusion of pearls glittered around the crest, scintillating on a sea of smaragdite, so that the eyes were almost blinded by the dazzling exulerance of the gems. Ilis trousers, a priceless sample of the weaver's art, were cmhrovdered on eloth of gold"; iv, 3. Cerlrenus $(i, 721)$ also furnishes stme curious details as what was foumd when lleraclius l, roke into the wea-ure city of Gazaca ant rifled the palace of Chosroes l'arviz (622). The contents of a private fire-temple astonished them. "On entering the spleerical chimber he found the impious effigy of Chosroes silting. as it were, in the heavens among the sun, moon, ant stars, whom the fanalic worshpped as gorls. Siceptrebearing angel stored around, and the wretch hat devised machines which di-charged water like rain, and emitted a sund as of thunder. All thi was comsumed hy fire."

'Ammianu, siii, 6; cf. Menamder, leeg., 1. 335: Theoploylacl., iv, S; letlers in which Chosreses, Nush. and larriz, asume all their titles.

"Herextetus, vii, 5t: ? C.mtius, 1, I (20).

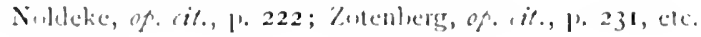




\section{The Persians and Justinian's First War 39I}

centuries of the Sassanian rule, in every instance the crown devolved to a prince of the blood of Ardeshir. ${ }^{2}$

A Persian army of this date was very similar to a Roman one, but there were some essential differences. With the exception of the Royal guards, which, like those of the Achaemenians, included a body of ten thousand, called "the Immortals," " and necessary garrisons, a standing army was not maintained. ${ }^{3}$ On each occasion, therefore, the fighting force had to be levied afresh whenever a campaign was in prospect, but, as a traditional part of Persian education was that every youth should be taught to ride and to become an efficient archer, 'the new recruits were not necessarily deficient in military training. During a battle, in fact, they relied chiefly on their missiles, and a Persian horseman was provided with two bows and thirty arrows. ${ }^{5}$ Less importance was attached to the infantry, but they also consisted of bands of archers. The cavalry were generally almost as numerous, and in addition a troop of elephants was often a prominent feature in a Persian army. ${ }^{\circ}$

The revenue of Persia previous to the sixth century was

1 As evidenced notably in the struggle between the successful rebel general, Bahram, and Chosroes Parviz; Theophylact. Sim., iv.

${ }^{2}$ Herodotus, vii, $8_{3}$; Procopius, De Bel. Pers., i, I4, etc.

${ }^{3} \mathrm{Jn}$. Lydus, De Magist., iii, 34 .

4 Herodotus, i, 136. Jn. Lydus (loc. cit.) says the whole nation was trained to arms, and always ready to enter on a campaign.

${ }^{5}$ Tabari (N.), p. 245. In Zotenberg (p. 228) the number is given as eight score, which would probably weigh the horse too heavily. Some injunctions as to armour are given in Vendidâd, xiv (32). Here also thirty arrows are recommended. For slingers, thirty stones each man is the fixed number. The horse and his rider were so well shielded with metal that Ammianus speaks of them as an "iron cavalry"; xix, I ; cf. $x \times v, i$.

${ }^{8}$ Ammianus, xxv, I; Procopius, De Bel. Goth., iv, I3; Aedif., ii, I. 
mainly derived from agricultural industry; and every inhabitant who cultivated the ground handed over to the state collectors a tithe of whatever economical growth his land produced. Cavades, however, from personal observation became impressed with the disadvantages of this system, which often seriously hampered his subjects in providing for their daily wants, and deprived thems of the full benefit of the newly ripened crops.' Thus the rustic population feared to be accused of falsification if they ventured to supply their present needs before the arrival of an official whose duty it was to inspect the produce of the soil and of the fruit-bearing trees while still in position, and to deliver to them their note of assessment. Cavades, therefore, decided on the abolition of tithes in favour of a land-tas, a sweeping reform, beset with many difficulties, which engaged his attention for many years, and was only fully established by his successor:" IVith the inbabitants of towns and villages, who did not

In Lotenberg, the reason why Lavádh was led to reform the iaxation is accounted for by an anecdote (p. 24t). One day while hunting he hecame separated from his party, and sat down to rest himself near a peasant's cottage. White there, he noticed a child bringing two or three grapes to its mother, who at once seized them and wilh great concern ran to attach them again to the vine, exclaiming that the inspector had not get been round to assess the amume of the croply. The alsurdity and harshness of the tithe law was thus practically exemplified to the shats. Both versions aclate that a strange scribe who ventured to dispute the soundness of the proposed financial change in an assembly convened to hear it announcel, being convicted of starting a fulile oljection by Cavades, was thereupon, al a nod from the monarch, belalonured hy his fellow seribes with their ink-homs till he expired. Ili, point was that the reiations of the land and it ownes would vary continually, and he was met ly the statement that there womld he a

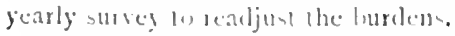

Tabai (X.), 111. 152, 222; /lik. (K.), 1.2.1. 


\section{The Persians and Justinian's First War 393}

subsist by agriculture, the Persians adopted the usual expedient, in this age, of imposing a poll-tax. ${ }^{1}$

The Sassanian Empire did not distinguish itself in the realm of art; and the scanty remains which have been discovered indicate that their architectural productions owed much to Byzantine co-operation." As temple worship was a minor feature of the Zoroastrian religion, which consisted almost wholly in forms of private devotion, ${ }^{3}$ no ruins pertaining to buildings of that class have been found; ' but in several places portions of dilapidated palaces exist, which enable us to estimate accurately the artistic proficiency of the Sassanians." The residence of the Shahinshah was a quadrangular edifice built around a central court. Externally the walls were diversified by two or three superimposed rows of slender columns, those rising from the ground being much taller than the upper ranges. The distinctive part of the architectural design was an arched entrance, wide and lofty,

1 Zacharial Myt., ix, 6.

2 Besides the ubjective evidence, there is a direct statement of the fact; Theophylactus Sim., v, 6.

${ }^{3}$ The practical application of the doctrine of the Avesta has been described at considerable length by Max Duncker $(0 \%$. cit., v), but the school of Darmsteter would aver that his exposition applies with more accuracy to the age of the Sassanians than to that of the Achaemenians, whom alone he deals with.

1 Some remains, almust certainly those of firc-temples, cxist, but they are architecturally insignificant, being, in fact, merely low stone towers a few feet square. The interior was only a cell with just room cnough to accommodate a small altar, on which a perpetual fire was kept up; see Ferguson, Hist. Archit., Lond., 1874, i, 202 ; cf. Perrot and Chipiez, Persian Art, i, $\$ 92$.

"The chief work which gives representations of Sassanian architecture is that of Flanclin and Coste, Voyage en Perse, Paris, 1851. Many have been copied by Rawlinson, op. cit. 


\section{The Age of Justinian and Theodora}

which led into a great domical hall, from whence small doors gave access to the various chambers of the palace. .1ll the apartments, at least those of any size, were covered with a domed roof. To the rather tasteless exterior decoration of these palaces the remains of an unfinished one discovered at Mashita, on the edge of the Syrian desert,' offers a striking exception. For several feet from the foundations the walls are covered with an intricate tracing of carving, in which lions, tigers, and doves, appear entangled amid the leaves and contorted branches of some luxuriant vegetation." $A$ considurable number of bas-reliefs have come to light among the ruins of Sassanian palaces, some of them illustrating the achievements of the dynasty during its wars with Rome and various powers, others representing hunting scenes in which are shown the methods of the chase and the magnificence of the monarch on such occasions amid his attendant throng of courtiers and guards. The execution of these works camnot be spoken of as art in the Hellenic sense, but in chiselling the forms of animal life some approach to excellence may sometimes be noted, especially' in the case of elephants. ${ }^{3}$. Is for literature, it appears that the Sassanians produced little or nothing national, with the exception of priestly elaboration of the Mazdean scriptures, but in the last days of the empire, a crude history under the title of Shahnameh, that is, a Book of Kings, was compiled.'

1 About twenty miles due east of the northern end of the Dead Sica.

- See Tristram S Land of Moal, Lond., IS73, and for a restoration, Ferguson, of cil., i, 392. The slats have now been remored to a Berlin museum, where they are attributed to the Ghasanicles, an Arab dynasly.

Sice the reproductions in Flandin and Custe, ete., op. cit.

'The work on which the well-known poem of lirdausi was founded (c. $1, \infty 00)$. There is much theolngical exegesis in l'ahbavi, lut, except 


\section{The Persians and Justinian's First War}

The first important commission entrusted to Belisarius by Justinian, after his accession to undivided power, was the construction of a fort at Mindo, a village on the Roman frontier between Dara and Nisibis. ${ }^{1}$ As soon as the news of this bold measure was announced to Cavades he determined to prevent the execution of the work by every means in his power. He had already despatched a considerable army under two of his sons through Persarmenia in order to make an incursion into Lazica. This force he now diverted from its original purpose, and directed them to march with all speed to the scene of the offensive operations. ${ }^{2}$ Information of the impending attack was immediately transmitted to the Emperor. He promptly resolved to frustrate it by a countermove of a similar kind. The troops posted in the province of Libanus under the brothers Cutzes and Butzes, two young Thracians, were therefore ordered to hasten northwards to strengthen the hands of Belisarius. Their arrival was welltimed, and the Persians found themselves intercepted before they could make an onslaught against the works. The Orientals halted and proceeded to encamp themselves

the Avesta and its commentaries, this is post-Mohammedan. Much of it has been translated by West, as stated above. The chief works in the collection are the Dinkard, a sheaf of treatises in nine books; the Bundahish, or "Story of Creation," a sort of Iranian Genesis, but of greater length; and the Sad-Dar, a controversial work, in which the follower of Mazda is taught to refute the "twaddle" of Christians and, guardedly, of Mohammedans.

'For the details of this war we have the first-rate accuunt of Procopius (De Bel. Pers., i, I2-22), an eye-witness of a great part of it. Additional information on some events can be gleaned from Zachariah Myt. (ix, I-7) and Jn. Malala, both nearly contemporary. The later chronicles are practicably negligible.

${ }^{2}$ Jn. Malala, xviii, 441; the inference may be drawn by comparing the passage with Procopius. 


\section{The Age of Justinian and Theodora}

methodically over against the Romans. They then took the precaution to cover their line secretly with a series of pits, at the bottom of which they fixed stakes, and afterwards restored the surface so as to give the appearance of unbroken ground.' The young 'Thracians, rash and inexperienced, neglected to observe the precise movements of the enemy, nor did they delay to take counsel with Belisarius, but pushed forwards impetuously to join battle with their opponents as soon as they were able to dispose their forces in order for an attack. The Persians calmly awaited the assault until the Byzantines had entered on the treacherous ground, and became disorganized by falling into the numerous traps which had been prepared for them. An indiscriminate slaughter then ensued, most of the officers being killed, but some of them were taken prisoners, among the latter being Cutzes. No effort could now avail to save the fort, which was at once abandoned by Belisarius, who, with the wreck of the army, made good his retreat to Dara.

After this disaster Justinian promoted Belisarius to the rank of Master of the Forces in the East, and authorized him to levy an army of the greatest possible strength. In this task he joined with him Hermogenes, Master of the Offices, whom, with Rufinus, a patrician, he despatched to the theatre of war. The latter was well known as a legate at the Persian court, and he was directed to take advantage of the customary suspension of hostilities during the winter, which was now at hand, to make overtures to Cavades for the conclusion of a peace. An interchange of propositions on the subject was kejt 11 ) for some months, during which the shah maintained an equivocal attitude,

' Zachariah My\%, ix, 2. The exact wordiug of the sentence is doubt. ful, but lise iniention in clear. 


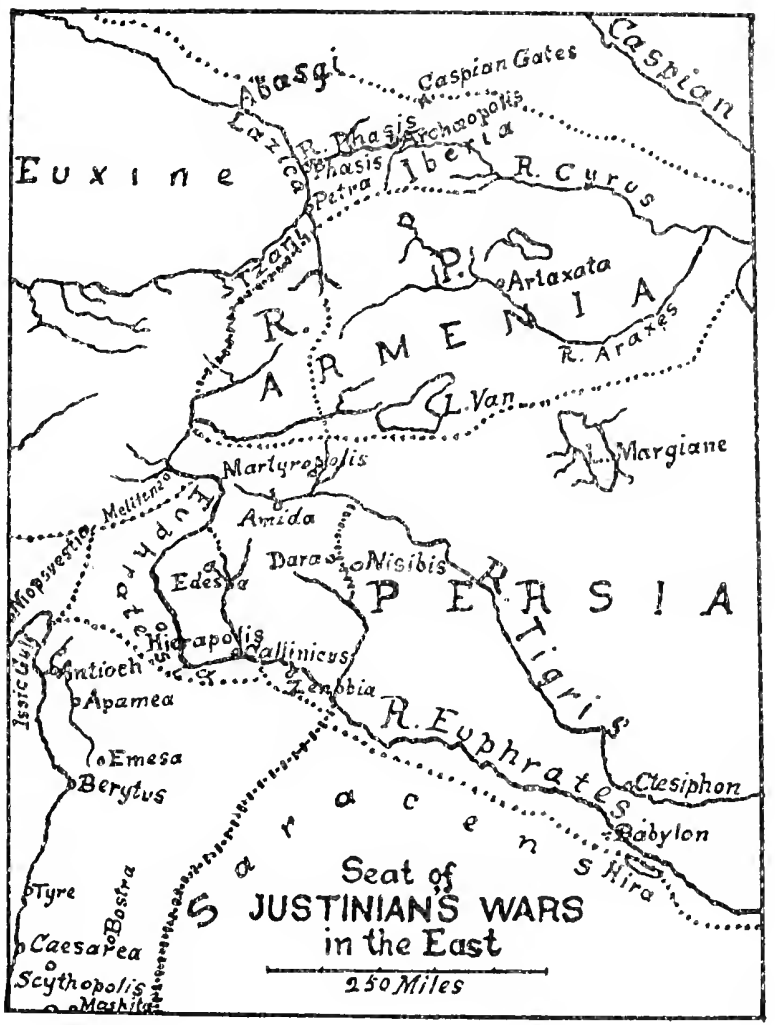



until, on the approach of spring, scouts brought in the intelligence that the Persians were advancing with a great army, evidently counting on the capture of Dara. In a short time a taunting message was brought to Belisarius from Perozes, who was in chief command, charging him to prepare a bath in the town against his arrival on the following evening. "This Perozes was one of the elder sons of Cavades, ${ }^{2}$ and his insolent confidence was inspired by the success of the recent action, in which he had borne the principal part. His notice was taken as a serious warning, and the Roman generals at once set about disposing their forces in order of battle, anticipating a decisive engagement on the following day. Their army consisted of about 25,000 men, most of whom were mounted, and they were drawn up within a stone's throw of the wall of Dara. Belisarius and Hermogenes, surrounded by their personal guards, posted themselves in the rear, next to the town. Immediately in front of them was ranged the main body of their troops, in a long line, made up of alternating squads of horse and foot. A little in advance of these, at each end, was stationed a battalion of six hundred Huns. ${ }^{3}$ Such was the centre to which, but at some distance forward, wings were supplied, each onc composed of about three thousand cavalry. A trench, interrupted at intervals for passage and dipping in to meet the centre, covered the whole of this formation in front, but excluding the two bodies of Hunnish horse standing at each reentrant angle. ${ }^{+}$Lastly, advantage

${ }^{1}$ Procopius, loc. cit., 13.

2 Malala calls him the eldest son, but in Procopius Caoses is the name given to the eldest; loc. cit., II; see p. $3 I_{4}$.

${ }^{3}$ Hunnish Foederati. According to Ammianus $(x x x i, 2)$ they almost lived on horseback, often not dismounting even to sleep.

$\star$ See Oman (op. cit., 28) for a plan of the battle with remarks. It II.

D D 


\section{The Ige of Justinian and Theodora}

was taken of a small hill lying on the extreme left to form an ambush of three humdred Herules under their native leader, Pharas.

As soon as the Persian host had established itself on the ficld, they were perceived to be much more numerous than the Komans, anounting to quite forty thousand men. 'The Mirrhanes, such was the military title borne by Perozes, drew up his forces in two lines with the design that when those in front were exhausted they should be replaced by fresh troops from behind, the movensent to become alternating, if necessary, with intervening periods of rest for each line. The wings were composed of cavalry, the famous band of Immortals being stationcd on the left, whilst Perozes himself led the van, supported by the heaviest mass of combatants. On the first day that the armies stood facing each other the Persians' left wing suddenly improvised a skirmish with those opposed to them, but retired after a brief collision with the loss of seren of their number. Later on a Persian youth of great prowess rode into the interspace and defied any Roman to meet him in single combat. No soldier seemed inclined to respond, but at length one Indrew, the tent-keeper of Buzes, lately a trainer of athletes at Constantinople, took up the challenge. The adversaries charged each other with poised lances, the l'ersian was unhorsed, and Andrew, quickly dismounting, cut his throat with a knife. The komans shouted with delight, whilst the Persians, chagrined, determined to retricre the mischance, and soon presented another champion. A horseman, middle-aged, but of great weight, advanced racking his whip and calling out for some confident oppo-

dne not quite accord with the phraseralegy of l'rocopius, but I find it improssible to understand him in any wher way. 


\section{The Persians and Justinian's First War 399}

nent. Still no response from the military on the Roman side. It last Andrew, despite the express prohibition of Hermogenes, advanced again and braced himself for the encounter. The pair charged, their lances glanced aside, but the horses crashed against each other breast to breast, and both animals rolled over on the turf. The riders essayed to rise, but the athlete anticipated his heavy opponent and despatched him before he could regain his feet. It was now almost nightfall, and both armies withdrew from their positions, the Persians to their encampment, the Romans within the walls of Dara.

Next day the troops were drawn out on both sides in the same order, but the Roman generals, relying on the peace proposals, which they considered to be still in progress, deemed it possible that a conflict might be avoided. They addressed a letter, therefore, to the Mirrhanes, representing the uselessness of further bloodshed at a time when their respective sovereigns were bent on the resumption of amicable relations. In his answer Perozes accused his adversaries of ill-faith, and declared his disbelief in the genuineness of their overtures on behalf of peace. To this Belisarius replied that Rufinus would shortly be at hand with letters which would convict the Persians of a wanton rupture of their engagements, and that they should be fixed to the top of his standard at the outset of the battle. The rejoinder of the Mirrhanes closed the parley; he expressed unbounded confidence, and reiterated his mocking request that a bath and a suitable repast should be prepared for him forthwith within the city. His assurance was, in fact, increased at the moment, for, that very morning, a reinforcement of ten thousand men had joined him from Nisibis. ${ }^{1}$

1 Procopius, 10 . cit., 14. 


\section{too The Age of Iustimian and Thiodora}

Is a prelude to the hattle the opposing leaders mutually harangued their men. "The recent encounter," said the Byzantine gencrals, "has taught you that the Persians are not invincible. lou are better soldiers than they, and it is easy to sec that on former occasions you suffered because you disobeyed your officers. The enemy knew it, and came on here trusting to profit by jour want of discipline, but since their arrival they have been awed hy your firm array. You see before you an immense host, but the infantry are contemptible, wretched rustics, and mere campfolluwers, fit only to dig bencath the walls or to strip the slain. They carry no arms to assault you with, and merely cover themselves with great shields to aroid our darts. Bear yoursclves bravely, and the Persians will never again dare to invade our country." On the other side, leroees bade his troops to take no heed of the skilful tactics now first observable among the Romans. "You think," said he, "that your adversaries have become more warlike because of this imposing formation. On the contrary, the ditch they have covered their positions with proves their increased timidity; nor have they, though thus protected, ventured to attack us. But never doubt that they will fall into their accustomed confusion the moment we assault them: and renumber that your conduct will hereafter be judged of by the shahinshah."

Shortly after midday" the action was begum ly the fersian archers, and, until the quivers were exhausted, showers of arrows were discharged from each side so thick as to darten the stiy. The rain of missiles from the Orientals was heaviest,

The cnemy, says Procopius, kepe the Komans standing in line all the forenoron in prevent their having theit midhy meal; they them. selves dorl not eat till subitum. 


\section{The Persians and Justinian's First IVar $40 \mathrm{I}$}

but an adverse wind rendered it less effective, so that the Byzantines suffered no more than they inflicted. On its cessation several thousands of the Persians bore down on the left wing of the Romans and threw it into disorder. Already the flight had commenced, when the six hundred Huns held in reserve on that side charged the left flank of the enemy; and simultaneously the three hundred Herules, rushing down the slope of the hill from their ambush, fell upon them behind. Terrified by these unforeseen attacks the Persians turned and fled indiscriminately, whereupon the Romans joined in a triple band to take the offensive, and inflicted on them a loss of fully three thousand before they could reach their own lines. Considering it unwise, however, to proceed too far, the Romans soon desisted from the pursuit, and retired to their original positions.

A moment later the Persian left wing, including the whole regiment of Immortals, made a fierce descent on those opposite them, and succeeded in beating them back to the wall of Dara. At the sight of this defeat, however, the Byzantine generals ordered the Hunnish reserve just returned from pursuit to join their fellows of the right wing, and launched the whole twelve hundred, together with their personal guards, against the enemy's flank. As a result that wing of the Persians was cut in two, the after portion being arrested in its charge, and among these happened to be the standard-bearer, who was slain on the spot. Alarmed at the collapse of the ensign, those who were fighting in advance, being the majority, now turned to attack the mass of troops who had gained possession of the ground in their rear. The discomfited right wing of the Byzantines, thus freed from danger, immediately rallied and dashed forward after their lately victorious adversaries. Simultaneously the 


\section{The Age of Justinian and Theodora}

general of the Persian wing in action fell before the lance of one of the leaders of the Roman reserves and disappeared from his saddle. A panic then seized on the Orientals, and they thought of nothing but escape by flight. From all sides the Romans rushed to make an onslaught on them, they became hemmed in by a circle of steel, and were slaughtered without resistance to the number of fire thousand. A general rout of the Persian army cnsued; the infantry; on seeing the destruction of the cavalry, threw away their shields and fled, but they were quickly orertaken, so that a great majority of them perished. Belisarius and his collcague, however, fearing lest the reartion of despair in so great a host might lead to some disastur, recalled their forees as soon as they judged the defeat of the enemy to be complete. Such was the victory of Dara, the achievement of which appears to have been due mainly to the military talents of Belisarius, whose age at this date (530) was probably under thirty.' For the rest of this war the Persians always avoided fighting a pitched battle with the Romans. ${ }^{2}$

I) uring the succeeding summer desultory hostilities were carried on in Armenia, where, as a rule, the Pyzantines had the advantage: and two fortified posts of some importance, Bolum and Pharangium, in the Persian division of that

Pury (op. cit.) makes him only twenty-fice, but later, in 562 , represents him an heing near seventy. Jis age can colly he guessed at from Procopius, le liel. leas., i, 12.

- If we antepe Oman"s interpretatson of the tactice of licli-arius (which

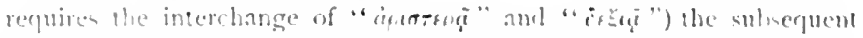
corlutions of the batcle become quate cleas. Fillowing the led as it

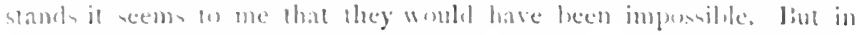

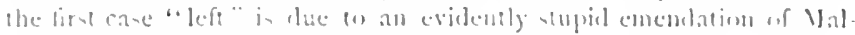

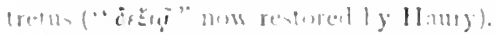

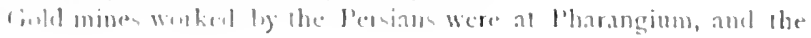




\section{The Persians and Justinian's First War 403}

country, fell into their hands. At the same time three Persarmenians, who held commands in the Persian service, deserted and fled to Constantinople. There they were received and provided for by a fellow-countryman of their own, the eunuch Narses, who at the moment filled the office of Count of the Privy Purse, the same who afterwards attained to great military celebrity.' This part of the war was conducted by Sittas, who had become the husband of Comito, the sister of Theodora. ${ }^{2}$ He also had been promoted to the rank of a Master of Soldiers.

In the meantime Justinian was still desirous of concluding a peace, and towards the close of 530 his ambassador, Rufinus, succeeded in gaining an audience of Cavades. In reply to a general appeal the Persian monarch complained bitterly that the whole responsibility of guarding the Caspian Gates had been thrown on his shoulders, and that the fortress of Dara was maintained as a constant threat against his frontier. He also adverted to the fact that Persia was a poor country, and accused the Romans of penuriousness in money matters. "Either," said he, "let Dara be dismantled, or pay an equitable sum towards the upkeep of the Caspian Gates." "He showed no inclination, however, to agree to

place was betrayed by the commandant in order that he might embezzle the stock of ore which he happened to have in hand; I'rocopius, loc. cit., 15. Jn. Malala (p. 455) seems to be partly in conflict with the above. He says the output was formerly divided between both nations, but in the time of Anastasins was wholly ceded to the Romans.

1 Procopius, loc. cit., 15.

2 Jn. Malala, xviii, p. 430: " He became engaged to her at the house of Antiochus, near the Hippodrome." This was probably an Imperial appanage or the house of some noble to whose guardianship the sisters had been confided on the elevation of Theodora.

${ }^{3}$ Cf. Procopius (loc. cit., 16), with Malala (pp. 449-450). He harked back to the old quarrel with Anastasius over the loan; see p. I76. 


\section{The Age of Justinian and Theodora}

any specific terms, and dismissed the Roman emissaries in the evident expectation that some decisive success would crable him to dictate the articles of a treaty. He was encouraged by the fact that he was entertaining at the time several thousand refugees of the Samaritan sect, who had been driven from their homes in Palestine by religious persecution. Such internal disorders must lessen the offensive powers of his rival, whilst the expatriated sectarians were wen anxious to bear arms against their late oppressor."

In the beginning of spring (53I) it became manifest that the Persians had been maturing a plan of campaign based on a strategical diversion, by which they hoped to surprise the enemy and possess themselves of a rich booty before their operations could be arrested. The originator of the scheme was Alamundar, his Saracenic ally, who pointed out to Cavades that if a descent were made on Euphratesia, the overlying province of Syria, they might advance to the walls of Antioch through a populous district teeming with wealthy towns but slightly guarded, and totally unapprehensive of their security being threatened. "Antioch itself," said he, "the richest city of the East, is always given over to public festivities and theatrical rivalries, and is divested of a garrison. Well might we capture it and make good our retreat to Persia without meeting with a hostile force. In Mesopotamia, to which the war has been confined hitherto, the encmy is prepared for us, and we can inflict no damage on them without engaging in a perpetual series of battles." His advice was acted upon, and a l'ersian general, Azarathes,

Jn. Malala, Hp. 445, 455; Procopius, Anecl, 11, 18. I pass over erents in which religion was the chief question at issue, as the whole can lee treated most instructively in a special chapher: sec leclow, chaj. xiv. 


\section{The Persians and Justinian's First War}

invaded Euphratesia with fifteen thousand horse, supported by a numerous body of Saracenic auxiliaries. The news of their entry on Roman territory was speedily conveyed to Belisarius at Dara, and he resolved to proceed at once by forced marches to meet the raiders. His army consisted of about twenty thousand men, including cavalry and infantry, and he moved with such rapidity that he succeeded in bringing the enemy to a stand at Gabbulac, before they had had time to commit any serious depredations.' Azarathes and Alamundar were taken aback at this encounter, which falsfied all their calculations. They were devoid of confidence in their power to resist a Roman force, especially when led by a general who had so lately proved his superiority; and they, therefore, decided to abandon the expedition and to retrace their steps with all haste to their own country. Belisarius, on his side, was well satisfied when he perceived that his adversaries were anxious only to beat a retreat, and he determined to leave them unmolested, but to follow their movements until he saw them safely over the border of the province. The two armies were separated from each other by about a day's masch, and they proceeded for several days in an easterly direction along the loank of the Euphrates, which lay to the left of their route. Each evening the Byzantines spread their tents on the same camping ground which had been occupied by the Orientals during the previous night." They began to cross the northern extremity of the Syrian desert." In the meantime, however,

1 Procopius, loc. cit., 18; cf. Malala, p. 462. The latter gives some details as to the mischief already done by the marauders, and states that the Antiocheans began to fly in terror to the sea coast. Gabbulae was about ninety miles east of Antioch.

${ }^{2}$ They were at this time almost exactly on the track of Xenophon when he accompanied Cyrus nearly a thousand years previously through 


\section{The Age of Justinian and Theodora}

the Roman troops had become inflamed with the desire to attack an enemy whom they saw constantly flying before them: and at length they broke into open murmurs against their general who, from sloth and timidity, they exclaimed, was restraining them from a glorious success. Belisarius strove to repress their ardour by urging that no fruitful victory was possible under the conditions present, whereas the enemy, if driven to desperation, might inflict a defeat which would restore to them their liberty of action, and be attended with disastrous consequences to the surrounding country. He also represented to his men that their strength was sapped by incessant marching, and especially by the fitsts imposed on them by the season of Lent, through which they were passing: finally, that a portion of the army had not yet arrived. At last he was overborne by their clamours, in which many of his officers joined, and even expressed his confidence that a general could not fail to conquer when in command of troops so eager to ba led into action.'

a country then strange to the (ireeks, but now become a part of their native land. His description is familiar to those of the del school: "In this place the earth was smouth all over, like the sea, and full of wormwool. Every wher kind of shrub or reerl was sweet-smelling and of the class of aromatics, but there was nothing in the way of a tree. . . With the limphrates on the right we arrivel at Pylac. In these stages many of the beasts of burlen perinhed of hunger; for there was no grass, nor any sort of tree, but the whole comntry was bare," etc.; Anabasis, $i, 5$. He adds that the only occupation the inhabitants had was digging up mill-utone; which they took to liakylon for sale.

llermuenes was aho present at this time, but only through havin: fallen in with the army as he was on his way to Itierapolis, where kufinuwas constantly stationed as the most convenient pust from which to open up diphomatic relations with Cesiphon. Zachatiah Myt. relates that Azarathes leggenl Belisurius bo postpone the batte on account of the "Nazareme and lews" in the Percian army, who were also keeping the fitus. 


\section{The Persians and Justinian's First War 407}

On Easter Eve the Romans overtook the Persians, and the two armies encamped in sight of each other at a short distance from the town of Callinicus on the Euphrates. The day was observed as a strict fast, but nevertheless on the Sunday morning Belisarius drew out his forces and disposed them in order of battle. His infantry he placed on the left, so that their flank should be protected by the river. The centre was composed of cavalry, among whom he took up his own station, whilst the right wing was allocated to a body of Saracens under Arethas, a sheikh who had been induced to become an ally of the Empire as a counterpoise to the power of Alamundar. On the other side two divisions only were made, the Persians occur ying the right and the Saracens the left. As usual the engagement was begun by the archers, who consumed nearly two-thirds of the day in emptying their quivers. The Persians, however, shot out weakly with relaxed strings, and their darts were to be seen continually leaping backwards after impinging on cuirasses, helmets, or shiclds. But the Byzantine bowmen, though much fewer in number, were more robust, and almost always succeeded in transfixing those whom they struck with their arrows. A determined charge on the Romans by the best troops of the enemy ensued, upon which the tribesmen led by Arethas, cowed by the superior prestige of Alamundar, fled almost without striking a blow. As a consequence Belisarius, with his cavalry, was surrounded on three sides, and subjected to a fierce attack which it was impossible to resist. A band of two thousand Isaurians, who had been among those most eager for a conflict, scarcely dared to use their weapons, and nearly all of them were slain on the spot. A large number of the centre, however, exhausted though they were with fasting, defended themselves strenuously, and in- 


\section{toS The Age of Justinian and Theodora}

flicted great loss on their opponents. When at length Belisarius saw that there was no hope for the residue of his cavalry but annihilation, he drew them off rapidly to the left, and joined those of the infantry who still held their ground on the river's bank. There, with great presence of mind, he improvised a phalanx, dismounting himself and ordering all his horsemen to follow his example. With scrried shields and projecting lances they formed an impenetrable mass which every effort of the enemy failed to break. Again and again the whole body of the Persian horse rode down upon the bristling phalanx; but the Romans drove them back with lance thrusts, and so terrified the animals by clashing their shields, that they shook their riders off. The conflict was only terminated by nightfall, when the Persians returned to their camp, and Belisarius, having obtained possession of a ferry-boat, transferred the remmant of the army to a safe retreat on an adjacent island of the river. Next day he summoned a batch of transports from Callinicus, and in a short time all were securely lodged within the town.'

Soon after the battle on the Euphrates Justinian recalled Betisarius to Constantinople and entrusted him with the organization of an expedition which be contemplated against the Vandals in the west. The chief command in the east then devolved on Sittas." As for the Persian generals who

1 Malala (p. 464), however, shows up Belisarius in a sery unfavour. ahle light. Is som as he saw that the day was lost, he seized his undard, jumped into a hoal, and rowed away with all speed to Calli. nicus. But sunicas, the leader of llo casalry he had abandoned, dismouncel and sustained the allack of the enemy as described by I'recopius. It is safert to believe the latt $r$.

- Here again Zachariah and Valata (p. \$66) ditter faom bocopius, and asert that Bedisarius was supersederl on acerume of his failure on 
had been opposed to Belisarius in the two leading engagements of the war, they incurred almost equal odium in the eyes of their royal master. The Mirrhanes was deprived of the rich insignia of an order of nobility which conferred a dignity second only to that of the throne; whilst Azarathes, who claimed the honours of a victorious general on his reappearance at court, could produce no evidence of his success and, after a muster of the troops, was upbraided by Cavades for having lost the half of his army. ${ }^{2}$

At this juncture Justinian seems almost to have despaired of obtaining a peace on any equitable terms from Persia, although he kept his legates, Rufinus and Hermogenes, on the confines of both empires in continual readiness to institute negotiations. He began, therefore, to devise some means of neutralizing the injurious effect of being in perpetual conflict with his impracticable neighbour. To provoke a hostile incursion against his antagonist from some remote frontier might force him to suspend his assaults on the Empire; whilst the serious interference with Byzantine commerce due to the import of silk across his enemy's dominions being in abeyance would disappear if the trade in that indispensable commodity could be diverted to some friendly route. The geographical and political situation of Aethiopia or Axum and the amicable relations of that kingdom with the Empire seemed to satisfy all the conditions essential to the success of this project. The civilization of Axum and part of its population had originally been derived from the Arabian province of Yemen, on the opposite side of the Red Sea. In the course of time the offspring prospered and turned

the Euphrates. But subsequent events show that P. is more to be trusted, and that Justinian attached small blame to Belisarius.

1 Procopius, loc cit., IS. 


\section{tro The sge of Justinian and Theodora.}

upon its parent: and by the middle of the fourth century the Negus ' of Axum had become the overtord of his less powerful neighbour, the king of the Homerites or Himyarites, as the inhabitants of that district of Arabia were called in this age. Christian missions began to penetrate these regions shortly after the reign of Constantine, and at the present time the Axumites were enthusiastic votaries of that religion and of Kome. Himyar, however, was full of Jews who had fled leefore Hadrian and his predecessors after the subjection of l'alestine and the destruction of Jerusalem, and, therefore, of religious dissension; and the championship of the Cross more than once fumished an occasion for the Aethiopian despot to carry his arms into the Arabian kingdom for the maintenance of his rather precarious sucerainty. Only recently, in the reign of Justin $(c, 524)$, the Negus of the day, Elesbaas, had crossed the gulf, expelled a lewish ruler, and cstublished Esimphaeus, a Christian, in his stead.

To Elesbaas, therefore, Justinian determined to apply; and forthwith detached an ambassador named Julian to enlist his aid against Persia. The embassy, provided with a letter and suitable presents, took ship for Alexandria, navigated the Nibe to Cuphos, crossed the desert to berchice, and from thence sailed down the Red Sea to Adule.' 'The Negus was trans-

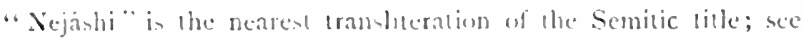

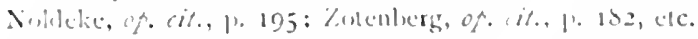

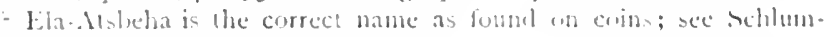
leerger, Kers, Numinmal, is 86.

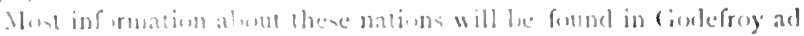

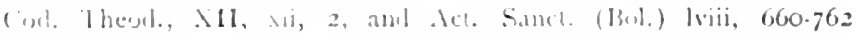

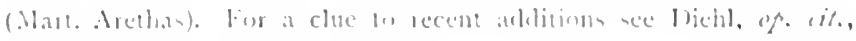
1. jos it ce, and letho, chaye xis.

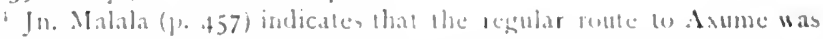

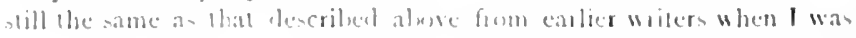


ported with joy as soon as he heard that a party of Roman delegates was approaching Axum, and advanced from his capital to meet them sustained by all the excess of barbaric state. He was standing on a lofty car adorned with plates of gold, which was drawn by four elephants. His guards crowded around him, each one armed with a pair of gilded spears and a small gilt shield, and a company of musicians blew with exultant strains on their shrill pipes. The dusky potentate himself was almost devoid of clothing proper, but was decked from head to foot with a profusion of precious ornaments. On his head he wore a white turban interwoven with gold thread and four golden chains hung from it on each side. A linen mantle weighted with pearls and golden nails, open in front, flowed from his shoulders; and a kilt seamed with precious metal was dependent from his girdle. I necklace and bracelets of gold, with arms similar to those borne by his guards, completed his equipment. ${ }^{2}$

Julian knelt and presented his letter, but was immediately bidden to rise, whilst the Negus kissed the seal of the missive, and listened to its contents as read by an interpreter. $\mathrm{He}$ at once promised compliance with all Justinian's requests; an army of his vassal Saracens should march against the Sassanian realn, and the cargoes of silk from Malabar should be diverted from the Persian Gulf to be discharged

sketching the commercial activities of the age; see p. I9o. IIe places the embassy before the action on the Euphrates, but his chronological sequence is often wrong. From Procopius (loc. cit., I9, et seq.) it seems to have been before or at least about the same time. The Berenice mentioned by Procopius (De Aeclif., vi, 2) is not that on the Red Sea (see p. I90), but on the Great Syrtis.

We owe this description of Soudanese pageantry to Jn. Malala (xviii, p. 457), who professes to be copying a report publisherl by the ambassador himself. 
at Sdule.' Ifter the lapse of a jear another envoy was despatched from Constantinople, and Nomnosus, one of a fimily of legates, familiarized with these regions by constant visits, traversed not only $A x u m$, but Yemen, in order to stimulate the execution of these important schemes. ${ }^{2}$ In the end, howerer, the project failed of achievement; the tribes of Himyar shrunk from entering on a long and arduous journey over the sandy wastes to attack an encmy whom they believed to be more bellicose than themselves, while the shipmasters could not be induced to avoid the Persian ports, where they found eager buyers for all the silk they could procule." The death of Elesbalas occurred shortly' afterwards, but not before an interion revolt had freed Him. yar for a time from the Aethiopian supremacy.'

In the next phase of the war, martial activity centred around Martyropolis, a fortified town of Roman Armenia, situated on the river Nymphius. I considerable Persian army, under several veleran generals, beset the stronghold with all the engines proper to a determined siege in the warfare of the period. It the same time Cavades, octogenarian though he was, resolute in his purpose to do all the damage possible to his adversaries, provoked an artificial irruption of the Huns into Roman territory, and opened the Caspian (iates to a great host of those barbarians. It his instigation they carried their depredations rapidly to the south, and in the autumn of 531 effected a junction with the l'ersian forces

I'rucopius, 10c. ile, 20; Malala, loc. it.

The abstract of Nonnusus's own accumb has been presersed liy l'hotius.

I'rucopius, loc. cit., 20.

livil., 19. Furbler delails in Talari, for which see chap. aiv below. 


\section{The Persians and Justinian's First War 413}

around Martyropolis. Buzes and Bessas commanded the garrison of the town, but without confidence in their powers of resistance to the assault; for not only were the walls easily surmountable in many places, but the beleaguered were ill supplied with sustenance, and with warlike machines to repel the assaults of the enemy. ${ }^{1}$ Nor had the Byzantines any troops in the field with whom they could hope to raise the siege; and Sittas, though posted at only one day's march from the scene of hostilities, feared to approach nearer with the slender army at his disposal." From time to time successful sallies were made by the besieged, and Bessas, who was a bold cavalry leader, now, as on former occasions, found opportunities of inflicting considerable loss on the foe; but nevertheless it was felt that a crisis disastrous to the Romans could not long be delayed." In this impass a stratagem was concerted and carried out effectively, which blunted the ardour of the siege and erentually saved the town. As in all ages, it was the practice to maintain spies in an enemy's camp; and between both nations there was a habitual interchange of renegades who were anxious to betray the secrets of their country, attracted by the substantial rewards which generally accrued to such treason. A man of this class was now at hand, one whose reliability had been tested by the Emperor himself, and he

${ }^{1}$ Procopius, $20 c$. cit., 2r. It should be noted that P. is not now relating his own experiences, as he returned to Constantinople with
Belisarius.

${ }^{2}$ Ibid. He was at Attachae, not far from Amida; cf. Zachariah Myt., loc. cit., 6.

${ }^{3}$ The exploits of Bessas are divelt on by Zachariah Myt., loc. cit., 5 et seq. Most details of the siege are given by Malala (p. 468 et seq.), which, howerer, I omit here as we shall have more interesting opportunities later on of studying the mode of procedure at sieges in this age.

11.

E $\mathrm{E}$ 


\section{$41+$ The Age of Justinian and Theodora}

was instructed to reveal to the lersian generals with professed good faith his pretended discovery that the Huns, corrupted by By\%antine gold, only awaited an opportune moment to change sides in their warfare. 'The spy executed his commission fathfully, and his communication was listened to with consternation by the military council," The Orientals, distrustful of their uncongenial allies, relaxed their energies, and the siege was protracted until the severity of the weather compelled a cessation of arms for the season. The Persians gladly agreed to a truce and retired into winter quarters, but the Huns, now freed from control, began to work their way towards the south with Antioch as their goal, plundering every assailable habitation which lay in their track. They were pursued unremittingly by Bessas, who cut up marauding bands, captured their spoils, and finally succeeded in chasing the survivors out of the country:

In the meantime an event had occurred which produced an immediate change in the relations of the two empires, and virtually ended the war before the advent of spring called for a resumption of hostilities. Early in September Cavades was suddenly prostrated ly illness, whereupon he summoned Chosroes, and caused him to he crowned hastily at his bedside. A few days afterwards he expired, at the age of eighty-two in the forty-fourth year of his reigne. As usual

1 Prscopius, loc. itt.

"He becane rich through these anceesses, says Zachariah Myl. II seems that in such canes the sprits became the property of the army, ant no altelupt was mate to resture whit was recaptured to the former isners.

Urientalint combider that Malala (p. 471) is lees informed here. Irocupiun relates that Cavalles left a will, on the strength of which

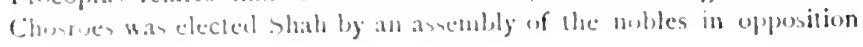


in Oriental successions the new Shah was unable to seat himself firmly on the throne without making away with several of his near relatives who formed a nucleus around whom malcontents might cluster.' Preoccupied, therefore, with his domestic affairs, he was anxious to be relieved from the onus of a foreign war, and signified shortly to the Roman legates his willingness to negotiate a treaty. ${ }^{2}$ Rufinus was credited with being a peculiarly grateful personage to Chosroes owing to his having consistently advised Carades, during his long intimacy with him, to elevate his third son to the throne. It was also reported that the Persian queenmother was in secret sympathy with Christianity and, therefore, used her influence over her son to promote peaceful relations with the Byzantines. ${ }^{3}$ But the lessons of the war

to the claim of the eldest son, Caoses; loc. cit., 21. Sometimes Theophanes seems to copy Malala, but in this case he is so ignorant as to make Chosroes succeed in 525 !

I Some details of this dissension are given by Procopius; 10c. cit., 23. A party conspired to set up a younger Cavades, grandson of the eller through his second son Zames, who was debarred by reason of his being blind of one eye. Ultimately this Kavádh fled to CP. (c. 546), and it is supposed that he is the authority whence Procopius derived his knowledge of Persian history. The historian, however, gives vent to his suspicion that this fugitive was an impostor, the real pretender having most probably perished.

Procopius, loc. cit., 22; Jn. Malala, p. 47I. According to the first the Roman legates sued for peace with cringing flattery, whereas Malala states that Justinian's reply to an announcement from Chosroes that he had ascended the throne was, "IVe do not acknowledge you as ling of Persia, nor do we permit our legates to visit you." Moreover he taunted Chosroes with having invited the Huns, and only after the latter had repudiated all responsibility for their acts were diplomatic relations established.

${ }^{3}$ Zachariah Myt., ix, 6, 7. He says that she was privately a convert to Christianity after a cure wrought upon her by a hermit when physicians had failed. 


\section{The Age of Justinian and Theodora}

had not been lost on Chosroes, and he felt strong enough to impose conditions so exacting that the Roman plenipotentiaries were unable to aceept them on their own responsibility. Invasion of the empire in force had been the distinctive feature of every campaign and, while l'ersian territory had heen subjected only to some desultory raids, the hrunt of the war had been borne by the Byzantines on their own ground. Ender an obligation to perform the double joumey in seventy days, Rufinus posted to Constantinople to hold a special conference with Justinian. Ite returned with a virtual consent to all the effective demands of Chosroes, and in less than a year after the death of Cavades a treaty was ratified under the reassuring title of "the Perpetual Peace." By this convention the substantial captures made by each party were to be exchanged; the fugitive Iberians were to be allowed the option of residing peacefully. in their own country or of remaining under the protection of Justinian: l)ara was not to be demolished, but the military Duke of Mesopotamia was to remove his headquarters from thence to an unimportant town at some distance from the fronticr:' and the Caspian Gates were to be left in the sole charge of Persia. The two last articles were concessions on the part of the Shahinshah, to counterbalance which the Romans agreed to pay an indemmity of one hundred and ten centenaries of gold $(\mathcal{E}+40,000)$.' Rufinus deposited the amount in specie at Nisibis, and the war was thus terminated with some military glory to the Byzantines, but with no

1 To Comstantina: cf. 1) Actif., ii, 5. A great deal of money was then yent in reatering it worthy of tis incseased importance. It appears 10 hase been about eighty miles west of Dara.

- The leme of the peace are only clearly expressed ly l'rucrpius, lot. it, 22: lo derlif., ii, 5. 
inconsiderable loss of their material possessions, which accrued for the most part to the advantage of the Orientals.

During the whole of this period the barbarians to the north of the Danube and Euxine were kept in a state of active commotion by various influences; and, if at any moment the countless wild hordes, who peopled that immense region, could have been moved by a unanimous impulse to hurl their combined force against the Empire, it seems impossible but that the Byzantine administration must have succumbed at once and finally to the irresistible shock. But there were always three forces in being which co-operated to avert such a catastrophe, and saved the Empire for many centuries from sudden annihilation. Its lengthened preservation in this connection was due to the diverse powers of arms, of wealth, and of religion. Conversion to Christianity was continually inspiring a proportion of these semi-savage races with a desire to enter into amicable relations with the Roman Emperor, in whom they saw the prime source of the mystical lore which they had just been taught to regard with awe. Rich presents were despatched to the most accessible of the barbarian rulers, who were thus induced to pledge their allegiance to the Byzantine state. ${ }^{1}$

1 Justinian's policy is well exemplified in a letter said to liave been written by him to a Hunnish chief: "I sent presents to you, intencling to honour the most powerful of your nation, and taking yout to be that one. But, while the presents were on their way, I hear that another has seized them, asserting himself to be the most potent among you. Now see to it that you prove yourself to be his superior. Take what you have been deprived of and revenge yourself on him. Otherwise we shall consider him to be the first, and he shall be favoured by us accordingly, and our presents will be lost to you." As a result of this attitude of the Emperor intestine wars broke out among the Huns, who thus mutually destroyed each other; Jn. Antioch. (Miiller), fg. 217; Alemannus, p. 400 . 


\section{4is The Age of Justinian and Theodora}

These various influences not only protected the limpire from many impending assaults, but, by animating the barbarians with invidious feelings against each other, often caused dissentient tribes to engage in the work of mutual self-destruction. Lastly, the residue who actually crossed the fronticr with hostile intent were met by the Masters of Soldiers, and with varying success checked in their adsance, or cut to pieces.

The influence of religion, at the same time conjunctive and disruptive, has already been exemplified in connection with Lazica and Iberia ; and a couple of nearly similar instances, occurring shortly after the accession of Justinian, will be noticed explicitly in a future chapter. ${ }^{1}$.In illustration of the advantage derived by the Emperor from the judicious bestowal of treasure on barbarian potentates is also brought before us during this war with Persia." Two Humnish kings, subsidized by Cavades, were on the march to join the Persian army with an auxiliary force amounting to twenty thousand men. But a queen of the Sabirian Huns, named Boarex, who had been the recipient of Justinian's liberality, was able to put a hundred thousand of her nation under arms. This martial female did not hesitate to attack her kindred; but, falling on them before they could reach their destination, destroyed the expeditionary force, slew one of the leaders, and sent the other to Constantinople, where he was impaled on the shore at Sycate, by orcler of the Emperor.' On the Illyrian frontier the Masters of the Forces in that region were in almost perpetual conflict with barbarian

Sec ch. xiv, leclow.

2In. Malala, [1]. 427, \$30; Theophanes, an. 6,020, clc.

thit. Walala saye she was won over ly" "gitts of hospitality, a collection of silver vases, and a considerable pesent in money." 


\section{The Persians and Justinian's First War $4 \mathrm{I} 9$}

raiders. Previous to 529 the command on the Danube had been entrusted to Ascum, a Christian Hun, but, being captured by a marauding band of his own race during a skirmish, he was carried off and permanently retained by them in their native abodes. He was succeeded by Mundus, a Gepoed of royal race, who had formerly been in the service of Italy. After the death of Theodoric, however, he placed his sword at the disposal of Justinian, to whom he proved a faithful servant not only in the defence of Illyricum, but shortly afterwards at a critical period of his reign in the capital. $^{1}$

1 Jn. Malala, p. 450; I'rocopius, De Bel. I'ers., i, 24. 


\section{CHAPTER V'}

THE SCHOOLS OF PHLOSOPHY IT ATHENS IND THEIR ABOLITION IIY IUSTINIAN

THE systematic teaching of philosophy at . Whens had 1 its origin in the dialectic of Socrates, whose mental hias impelled him to a persistent search after the fundamental truths which underlie the sociological organization of mankind. His constant effort was to discover what principles should be instilled into young men in order to render them worthy members of the community; and in pursuit of this object he made a practice of perambulating the city intent on applying his method of question and argument to all persons accredited with any kind of knowledge. Thus he laboured unremittingly in earnest effort to elicit sound opinions or to convict of fallacy. Every Greek town was adorned with a gymasium, and large cities, such as Athens, pussessed several institutions of the kind. Established for the physical training and athletic development of youth, a gymnasium consisted of covered halls, of porticos provided with sculptured stone seats, and of a small park or exercise ground shaded with plane and olive trees.' Ultimately the gymmasiums assumed something of the form of the colleges

Vitruviu $(r, 11)$ is the source for the lopnegraphy of the gymmasum, liceker-folls. Chariche for the elaburation of sentered details. 
of a modern university, and were resorted to habitually by teachers of young men, sophists, rhetoricians, and philosophers, in order to procure pupils, and to lecture to classes already formed. In such localities Socrates found most scope for his activities, ${ }^{1}$ but, after his death by a judicial sentence in 399 B.C. as an innovator and theological sceptic, his system of inciting the youth to seek after genuine knowledge was not publicly professed for a number of years. In the course of a decade, however, the Athenians repented of their severity, and Plato, who had been his principal disciple, was allowed to resume Socratic instruction in a suburban gymnasium called the Acadeny, ${ }^{2}$ situated on the north-west of the city. This institute proved to be the first permanent school of philosophy founded at t thens, and was always known as the Icadeniy, although Plato soon removed his classes to a private garden which he acquired in the vicinity, where he built a Museum, or Hall of the Muses, for their accommodation. ${ }^{3}$ Plato had numerous successors, all of whom continued to teach in the same garden, which was inherited regularly for many centuries by the chief of the Academy.

The most remarkable pupil of the original Academy was Aristotle, a native of Stageira, but he, after protracted studies, finding that his thirst for knowledge remained unsatisfied by the dreamy and inconclusire philosophy of his master, determined to follow a more practical path of inquiry according to the bent of his own genius. Observa-

${ }^{1}$ The liveliest picture of Socrates debating in a gymmasium will be found in Plato's Lysis.

${ }^{2}$ Diogenes Laert., Plato, 9, 14; Pausanias, i, jo; cf. Pliny, Hist. Nat., xii, i.

${ }^{3}$ Diogenes Laert., Speusippus, 3.

${ }^{+}$Damascius, Vit. Isidori, 158; Suidas, Plato. 


\section{The Age of Justinian and Theodora}

tion and correlation of facts, sociological, zoological, and physical, assumed the greatest importance in his eyes, and he thus became the founder of natural science in the widest sense. The Stagirite essayed to teach in various places, and was successful in impressing his views on many of those with whom he came in contact. His growing reputation attracted the attention of Philip of Macedon, who soon claimed his services for the tuition of his son Alexander, and embellished his native town as an inducement for him to open a school there.' ln a few years, however, the young prince passed from his class-rooms to the throne, and Aristotle migrated to Athens, where he fixed on the Lyceum, a gymmasium in the eastern suburbs, for the scene of his prelections ( $c .355$ B.c.). More than half a century had elapsed since the foundation of the Academy, and l'lato had now been dead for many years. In the shady walks of the Lyceum Aristotle continued to give instruction for a dozen years, and it is understood that he usually kept on foot, moving about while discoursing with his disciples, whence the sect received the name of Peripatetics," that is "promenaders."

The third philosophical school at Athens was established, about twonty-five years later than that of the Peripatetics, by \%eno of Citium, in Cyprus, who is reputed to have been inspired by reading treatises emanating from the followers of Socrates.' Zeno convened his disciples in the heart of the city, in a colonnade called the Painted Stoa or Porch,

1 Plutarch, Alexander, 5.

$\because$ Diogenes Laert. in lia 4,7 .

'Zeller, in his History of Philosolhy, prefers this explanation of the mame. It is also held that they were so designated merely because A. laught in the $\pi$ efitiarog or promenale of the gy)masium.

1 Diogenes Lacrt., 3 . 


\section{Abolition of the Schools of Philosophy 423}

whence the name of Stoics became attached popularly to his philosophical coterie." As the founder of Stoicism was an immigrant from the near East his mind was overcast by the Oriental sense of resignation under oppression ${ }^{2}$ and an ethical doctrine of doing and suffering in a world of adversity was the gift of the Porch to the humanity of the period. The circumstances of the times created and gradually increased the need for such a philosophy in the West. Grecian liberty passed under the despotic sway of Macedon, and later, under that of Rome, whilst the Latin Republic at length succumbed to the ambition of its military chiefs, and an arbitrary emperor usurped the place of a spirited democracy. Thus the tenets of all those ardent souls who shunned the servility of a court, and chafed under political restraints which they were powerless to throw off were derived from Zeno. ${ }^{3}$

The foregoing schools were essentially of a theological cast, and inculcated more or less dogmatically an attitude of veneration and piety in respect of a divine providence, but the leading feature of a fourth, founded about the same time as that of the Stoics, was a frank repudiation of any form of religious ritual. Epicurus was an Athenian by blood, but his youth had been passed abroad; ${ }^{1}$ and he claimed to have originated, without the aid of a master, ${ }^{5}$ the rule of life which he taught to his disciples. At the age of thirty-five he settled in his ancestral city (306 B.c.), within

1 Diogenes Laert., 6, 7.

2 Cyprus was at first Phoenician; later at various times Greek, Egyptian, and Persian.

${ }^{3}$ The best known Roman Stoics are Cato of Utica, Seneca, Lucan the poet, Helvidius Priscus, Arrian, Epictetus, and the Emperor Marcus Aurelius.

${ }^{4}$ Diogenes Laert., Epicurus, 1.

${ }^{5}$ Ilid., 7. 


\section{t2t The Age of Justinian and Theodora}

which he purchased a garden for the reception of those whose inclinations were in harmony with his peculiar doc. trines.' 'The vanity of human effort, and the superiority of a simple life of ease and contentment, formed the burden of the Epicurean didactic. In seclusion the tranquil mind might apply itself to intellectual pleasures, as oblivious of the gods as they themselves evidently were of the restless race of mortals. Itath was merely the term of life, and no anxiety as to a hereafter should ruffle the placidity of a man of philosophical temperament. Is "Know thyself" was the germinal thought of the Socratic school, so "Live unknown" was that of the Epicurean. In asceticism of this hue, which advocated the suppression of all energy, whilst allowing a mild, but aesthetic indulgence of the passions, was extremely acceptable to the arerage man of the period, for whose sensuous nature it afforded the consolations of Stoicism without the strain inseparable from that vigorous doctrine. ${ }^{2}$

The philosophers of these four sects maintained their position at Athens as dictators of human thought for more than fove centuries before their vitality leggan to be chilled into immobility by the new life which was arising in the widely (hristianized Empire.. When Marcus Aurelius halted at dthens in 176 , on the retum from his Asiatic expedition, he found the schools in a flourishing condition, and gave them a firmer constitution by bestowing a fixed salitry of 10,000 (trachmas $(f, 400)$, payable by the Imperial treasury, on the heads of each of the four. ${ }^{3}$ It is improbable

Dingenes Laert., Epicurus, 9, 10; l'liny, xix, +4.

t The chief Roman Epicureans were Lucretjus, the pretical expositor of his y tem, Herace, Alticus, and the yenuger Pliny.

Dio Iass., Ixxxi, 31; l'hilostratun, V'il. soph., ii, 2. The action 


\section{Abolition of the Schools of Philosophy 425}

that this subsidy was assured to them for long after the death of that emperor ( 180 ), or that they could have claimed it successfully in the disorganization of the Empire which followed the murder of his son Commodus (192). But Pagan philosophy was still independent of state aid, and the first step in the dissolution of these schools had its origin within when their individuality was submerged by the tide of eclecticism, upon which Neoplatonism rose to preeminence about the middle of the third century. ${ }^{1}$ Henceforward Athens had a serious rival in Alexandria, and somewhat later in Pergamus, ${ }^{2}$ whence the mysticism and theurgy of Plotinus and Iamblichus enthralled the senses of almost all non-Christians by the fervent hopes to which they gave birth. 'The teaching of the Academy, of the Peripatetics, and of the Porch, were the soul of Neoplatonism, but the Epicureans were abhorred by the new school as being most hostile to their vivid theistic aspirations, and at this juncture that sect must have rapidly become extinct." Subsequently to 425 , the year in which the Auditorium at

in Lucian's "Eunuch" is laid at this time, and seems to represent a real contest. The castrate claimed one of the salaried positions, but an outcry arose in view of his emasculated condition. The most obvious objection taken appeared to be that a philosopher should be adorned with a long beard. "In that case," he retorted, "your best plan would be to elect a goat." The litigation had to be referred to Rome, but with what result we are not told.

1 See p. 258 et seq.

2 In the time of Julian Perganius was the most active centre of Neoplatonism; and his principal tutors, Aedesius, Chrysanthius, and Maximus, taught there. For their ridiculous practices, half charlatanism, half fanaticism, see the lives by Eunapius.

3 " Away with every word of Epicurus and Pyrrho!' exclaims Julian. "Thanks to the gods, most of their books are now lost." Frag. Epist. (H., p. $3^{86)}$. 


\section{The Age of Justinian and Theodora}

Constantinople was founded by 'Theodosius II,' the Athenian rhetoricians, so famous in the youth of Julian and Gregory Nazianzen, appear to have suffered greatly in prestige, but long before that date the teaching of philosophy was in the way of becoming a lost art at Ithens. The disappointment of synesius at finding no trace of the schools, when he landed in Attica about 410, has already been adverted to. ${ }^{3}$ If, however, be had carried his investigations a little decper he would have discovered that in at least one quarter the traffic in the honey of Mount Hymettus was not the sole care of the dwellers on the Cephisus. The grarden of Plato, even at that date, was still possessed by the philosophic succession,' and the actual occupant, the renerable Plutarch,' had achicved a reputation which deserved the devotion of several eminent disciples. Yet the school was languishing, and even after the murder of Hypatia, the holder of the professorial seat, Syrianus, was apprehensive lest he should find no worthy successor." But a movement of recuperation was at hand, and surviving Neoplatonists soon began to turn their eyes towards Athens as the appointed retreat of the sect. I new rotary had

1 Sie p. 207.

"Among the most noted of these teachers was l'roaeresius, who is described as a colossus, nine feet high. Juring a visit to Rome he male such an impresion that a statue was erecied to him with the inscription: "The Q lueen of Cities to the Prince of Eloquence." IIe, howerer, was a Christian, and, therefore, was forced to resign ly Julian. liy way of a set off in this giant, another sely alde rhetorician, Alypius, was a pigmy; see their lives ly Eumapius.

SeE 1\% 207.

' Damascius and Suidas, loi cit.

"Usually reforred to as the son of Nestorins to distinguish him from the well-known writer of lives, who lived moder Trajan.

Marinu, Vita Procli. 


\section{Abolition of the Schools of Philosopliy 427}

arisen, gifted with the genius to revive their hopes, and to infuse a fresh enthusiasm into their almost moribund philosophy.

One evening in the summer of 43 I a youth of nineteen, having made the voyage from Alexandria, disembarked at the Piraeus and was received on the shore by Nicolaus, a countryman of his own, and some other friends who had been apprised of his coming. Proclus belonged to a Lycian family, but was born at Constantinople, and he had already won a reputation as a student of extraordinary powers and promise. This youth was regarded as the last hope of the expiring school, and when the custodian at the entrance of the city exclaimed, "I should already have shut the gates, had I not seen you approaching," the utterance was hailed as an omen symbolical of its resuscitation. Before entering Athens, Proclus complained of thirst and fatigue, and by a fortuitous circumstance rested in a seat and had a drink from a fountain, which were known as those of Socrates. Such auspicious occurrences redoubled the expectations which were kindled by his advent, and even the aged Plutarch issued from his retirement to superintend the initiation of the new pupil. ${ }^{1}$

The general doctrines of Neoplatonism, as a practical religion, had been fixed by Plotinus and his immediate successors, and nothing remained for later devotees but to elaborate the details of the system by analysis and disquisition. The execution of this task fell to the Athenian school, and for more than a century its members busied themselves in spinning a fine web of scholasticism around

1 Marinus, Vita Procli. The schools of rhetoric were not extinct at this date, as they are stated to have made overtures to Proclus, but he refused to engage himself to any of them. 


\section{$42 S$ The Age of Justinian and Theodora}

the fundamental principles of their faith. Its roots were traced backwards to Plato and Aristotle, and the complexity of every libre was demonstrated hy the aid of certain mystic bymms, supposed to be of ancient date, termed Orphic and ('haldacan oracles. Proclus, as had been anticipated, succeeded to syrianus, and from his labours in this field resulted a second summer of Ne(p)latonism, which bloomed for fully filty ycars.

The theology of Plotinus hat been comparatively simple, but it became more complicated in the hands of Iamblichus, whilst in those of proclus it assumed a comprehensiveness

1 It is generally agreed among scholar that the writings of Orpheus now entant are spuriou, foductions emanating from the Neop latenists themetres, who, as a pious fraud, cxpruded very scanty relics $t 1$ con. siderable bull: with the olject of providing an old traditional basis for their theology. In this age the daughters of philosophers, like llypatia, uften worked with their fathers, and, when adranced cnough, gave instruction to the clanecs. Thus Aclepigencia, the laughter of Plutatch, was the only one versed in the so-called Chaldacan fore, and she in that departmen: became the preceptres of Iroclus; Varinus, of cot. The work of Dam. cius (Vit. Isidm.) is dedicated to a certain Theodora who, with her sisters, had been pupils of himself and Isidorus. The conrse of stmly is shown to have been prolenged and comprehensive, edending sometimes over a decale or more. It included rhetoric, dialectic, literalure in prone and verse, mathematics, and astronomy

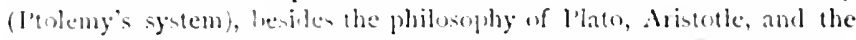

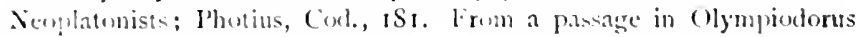
(Creuzer, Frankf., ISzo, ii, Pp. xii, 141), it seem that to the last the selesel continued to be open free to students as in the days of l'lato himelf. The fact is atso inticatedly the anectote related of Eroacresius and his friend lephacstion. Armenians beth of them, they andived at Athens so destitute that they posiessed between them only chething sutficient for one person. When, therefore, whe west out to hear a

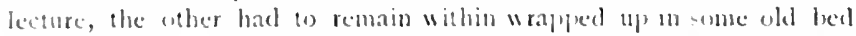
coverlete: (bumapius in Vit.). J'resents must, heseres, have been

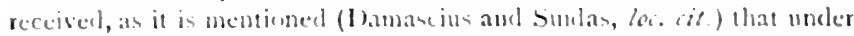

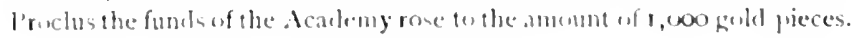


and extension which enabled it to find a place for all metaphysics and mythology within reach. The great conception of the Lycian philosopher was his ternary system, by which he succeeded in deducing the whole invisible world, as well as the objective universe, in a series of triads from the supreme One to the remote apogee of matter itself. ${ }^{2}$ All these speculations he embodied in a number of vast treatises, ${ }^{2}$ several of which are extant and have been rendered into modern languages by some thinkers of the last century, who found his cosmology more illuminating than that of the creed of Christendom. ${ }^{3}$

1 Vacherot has arranged a table, in which the numerous divinities admitted by Proclus are seen according to their roll of precedence; Ecole d'Alexandrie, Paris, I846, ii, p. 378 . A comprehensive work by Jules Simon with the same title came out almost simultaneously. Zeller (Philos. d. Griech., v, pp. 548 , So 8 ) defines the position of matter according to the views of l'lotinus and Proclus. The first considers it to be the original evil, but with the latter it is neutral, and bad only in relation to that which is better. These notions, however, are embedied in pages of refinements, so that no real finality is attained.

"By the age of twenty-eighl Proclus had finished his conmentary on the Timaeus, which exceeded in bulk the whole writings of Plato. Half of it is lost, but the portion preserved makes a ponderous tome.

${ }^{3}$ Victor Cousin and Thumas Taylor. The latter professes himself to be a complete convert to the religion of Proclus, and the former, who was a lcarter of thought, almost goes as far. The difference in theological standpoint between Christians, Stoics, and Neoplatonists is explained by the historians of philosophy. The Christian triune Gorl exists apart from the universe, which he produces by his own voluntary act. With the pantheistic Stoic: the Deity is pervasive without limit, and in all best things most immanent. Thus the good man may be his most perfect manifestation, and in no degree less than Zeus himself. But the essence of Neoplatonism is the Oriental conception of emana. tion, and in this pantheism everything is viewed as progressively inferior in proportion to its distance from the transcendent source, i.e., the One. In this system the good man cannot be equal to the Deity; he can only endeavour to elevate limself to reunion with his source by ecstatic

I1.

F I 


\section{4jo The Age of Justinian and Theodora}

The life of Proclus was written hy his disciple and surcessor Marinus; and from this document we gain some insight into the mode of life of a pious Neoplatonist. The Athens of that day seems to have retained at least the external aspect of the classical capital as it has been described by the early topographers. The principal monuments of polytheism were still erect, and Proclus had the satisfaction of occupying a house between the temples of Aesculapius and Dionysus, from which he could behold the Parthenon. The sect was strongly inclined to vegetarianism; and abstinence from animil food, though not strictly enforced, was advised in deference to the possibility of metempsychosis.' They worshipped the heavenly bodies and practised daily a set form of adoration to salute the sun and moon at their rising, meridian, and setting. Every month a ceremonial bath in the sea was considered to be essential as a tribute of respect to the divinity of that element, Poseidon. Although celibacy was not enjoined, it was approved by the exanuple of the great lights of the sect, who never married, hut they were not on that account precluded from illicit scxual indulgence to a moderate extent." The life of Proclus was

detachment from all lower grades. In the other sysems the worlel had a beginning and end in time, but the eternity of the cosmos was a necessary dogma of Nenplatunisn.

' See Porphyry s clahorate tratise, De Abstineutia ab Esu Carnium. Ite tries to prove the guasi-humanity of animals; they have a language of their own, which some men have understond, elc.

- I'roclus, like l'butinus, acted the part of a father an ail the young penple of his acymamance. l'orphyy, womewhat late in life, married a wilew named Marcella, stating that he only did so in order to fulfil the paternal office lowardo her chikfen. Vet fornication wa nol a Seopla. tonic sin, and evels l'ruclus resolted to it restrainedly. A letter of Porphyry to Marcetla, a comlensed manual of cthic, iv extant, and has recently appeared in an Einglish dreso. 
an exceptionally busy one owing to the interminable ritual he imposed on himself; for, in fact, he declared himself to be the "priest of all religions," " and he laboured incessantly to act up to that character. As a teacher he was indefatigable, lecturing five times daily, apparently to crowded audiences in a theatre, whilst his evenings were devoted to philosophic colloquies. He was, of course, reputed to be highly favoured by the gods, and his biography is almost as full of marvels as a Christian Gospel. Celestial visions were frequently vouchsafed to him, especially on the occasion of the sacrilegious removal of the statue of Athena from the Parthenon by order of the state olficials. The goddess incontinently appeared to Proclus and announced that henceforth she would dwell with him in his own house." He was an adept at incantations, by means of which he procured a rainfall in time of drought and arrested the progress of an

'Or literally, "the hierophant of the whole world."

"Marinus also informs 11 s that he was on terms of great cordiality with Pan, but according to another authority this god had dicd some centuries previously. 1'lutarch (De Defect. Orac., 17) lells us, on the report of "a well-known man of very sound character," that a vessel sailing in the Ambracian Gulf touched one evening at the Isle of Paxac. Shortly, a voice from the land thrice summoned Thames the Egyptian, one of the crew, and gave him the injunction, "When you come to Paloda, annomnce that the Great Pan is rlead." The mandate was obeyed, they put in at a deserted spot, and Thames, standing in the bows, shouted the required information. Immediately the whole ship"s company heard "a deep groan, proceeding as it were from a multitude of men." The news was carried to Rome, and Tiberius, after interviewing Thames, decided to hold an inquest. All the savants of the Court sat on the deceased, and, without viewing the body, pronounced him to be Pan, the son of Hermes and Penelope. The witness in this case was doubtless of the same class as those who from time to time contribute marvels to the reports of the Psychical Society and the Occult Review. 


\section{Hi2 The Agr of Iustimian and Theortora}

cartheptake which threallened destruction to . Ithens. The sick were often restored ly his prayers, which, however, he secms to have relied on merely for the purpose of invoking success on the orthodox medical treatment. Prochus atlempled to wield some power in local politics, and at one time incurred the enmity of the predominant party, doubtless the Christians, so that he deened it wise lo retire into exile for a welvemonth.' He died at the age of seventythree $(485)$ and was buried near Mount Lyeabettus in a bilocular sepulchre with his master Syrianus, for whom he always entertained the greatest veneration."

After the death of Proclus, the Neoplatonic school of Athens was probably somewhat echipsed, but considerable wetivity was still maintained, and votaries continued to be drawn to it from Alexandria and other parts of the Empire."

1 The alumni of the school went and taught in other places; for in. stance, Agapius, a hearer of l'roclus, under whom Ju. Laflus stmilied (De Magist, iii, 26). the same, perhaps, wh" wats the "ligy wig" of the meclical faculy at CP., ahout that time. ant mate a large fortune, as related by Danascius and suidas. Damancius (Vit. I-ilori) gives an account of the practice of Jacob Psychristus, an eminene physician of the latter part of the tifth century. IIe lauscel chictly to purgations, laths, and dicks, hed the knife and cautery sparingly, and repudiated lleeding. On visiting CP. he found the profession there neither experienced nor learned, but relying on a mutine derivel from their predecenors, which they followed in a llind and careless manner. Pamprepius, one of the alsest disciples of l'ruclus, deserted the Academy for the bivantine court, and altachen himelf to Illus, the great rebel in the reign of \%eno; but ultimately he was excculed hy his patron for having wntued on predictions which were falsifich ly the crent; Suida, sh. nom. (Malchus); Theophanen, an. 5976, cke.

- Marinu, of cit., alf fin.

Of this period there is a sort of chronicle cxtant in the form of a life of Isirtore of Gaza, who became scholarch next after Marinus. The whole worli has been aluilged from the original of I lamancius ly' l'hotius 'Corl. 2.42), and portions of it ase given hy suidas, ap parently 


\section{Abolition of the Schools of Philosophy 433}

Although it was recognized by the devotees that the evolution of metaphysical doctrine had reached its final stage, the endless task of commenting on Plato and Aristotle still kept their pens busy, and they continued to exercise their ingenuity in reconciling the views of those masters. ${ }^{1}$ In 522 , however, their labours were abruptly brought to a conclusion by a decree of Justinian that there should be no more teaching of Pagan philosophy at . Ithens." The piety or enthusiasm of Proclus had led him to declare that he would welcome the destruction of all writings except the Timaeus of Plato and the oracular hymns, ${ }^{3}$ a confession which reminds us that devotion to some special study is apt to blind our perceptions to the value of all extraneous knowledge. An Imperial Proclus would doubtless have emulated the example of the Emperor Julian and aimed at the suppression of Christianity. Justinian was a devout student of the Nicene theology, and arrogated to himself the chief place among the doctors of the Church.' He was naturally proclive to fanaticism, and

in full, under various biographical hendings, e.g. Aedesia, Archiadas, Asclepiodotus, Domninus, Ilegias, Hermeias, Hierocles, Pamprepius, Salustius, Serapion, etc., all philosophers of this later time. The narrative is stuffed with nonsense to an even greater extent than the life hy Marinus, and gives instances of prophecy ly crystal-gazing, of casting out of devils, etc. Curiously enough, it contains some of the earliest recorded observations of electric phenomena, viz. an ass of Tiberius and a horse of Severus that emitted sparks; that fire issued from the hody of Walanir, father of Theodoric the Goth, without singeing his clothing, etc.

'Syrianus had deroted himself particularly' to this task, and his ex. tant commentaries are a necessary part of the armament of the modern Aristotelian.

"Jn. Malala, xviii, 45I. Alemannus (op. cit., p. 459) cites an anonymous Greek cluronicle, in which astronomy as well as philosophy is prohibited.
${ }^{3}$ Marinus, op. cit., ad fin.
${ }^{4}$ Jn. Ephes, Com., p. 249 


\section{3t The Age of Justinian and Theodora}

it could scarcely be expected that his mind would be less warped by his restricted studies than that of the lagan philosopher, nor that he would display a tolerant disposition on funding himself in the seat of power. It became his settled conviction that profane learning was an idle pursuit, and he decided to enrich his treasury by forfeiting the grants which still continued to be paid to physicians and professors of liberal education.' As the result of this policy a general illiteracy leygan to pervade the Empire, ${ }^{2}$ but ultimately Justinian was induced to restore the stipends. ${ }^{3}$

When the philosophers of the day found themselves reduced to silence by an Imperial prohibition they took counsel together and resolved to desert an empire in which their only prospeet for the future was isolation. Is they glanced around them in search of a new sphere of activity, the West, almost relapsed into harbarism, presented no aspect hospitable to philosophy. From the East, however, a ray of illumination had recently penetrated to their classic retreat and warmed them with the hope of being received as welcome immigrants at the cout of the Persian momarch. In that kingdom, it was rumoured, the posture of affairs was one of such ideal felicity that the dream of Plato,' as to the occupant of a throne leing at once a prince and a philo-

1 Procopius, Ancol., 26. Olympiodorus (op. cit.), writing probalily' just before the closure of the schurls, notices that these confiscations hat lieen gring on for some lime. It secms that Justinian hegan cystematically to seize on the property of all teachers he clisapprowed of.

2 Zomaras, xir, 6.

"The Pragmatic Sanction adtresed to Pope Vigilius (55.4) indicates the restoration; scct. 22. It would seem that state aid must have been in abejance for wenty gears or more, as the cridence of lrocupius ex. levelis lis $55^{\circ}$.

- Rejmllic, vi. elc. 


\section{Abolition of the Schools of Philosophy 435}

sopher, was fully realized. Everything was under the sway of the just and honourable; thieves and bandits and perpetrators of iniquity were no longer born there; so that the most precious property might be left unguarded in the desert with the certainty of its remaining intact until the owner should reclaim it. The youthful Chosroes, whose accession had lately been announced, was the author of this beatific revolution. An enthusiastic student of Greek litcrature, he had applied himself to the study of Aristotle with a zeal equal to that of Demosthenes when he made repeated transcriptions of Thucydides. 'The works of Plato were not less familiar to him; nor could the subtleties even of the Timaeus and the Parmenides escape the acuteness of his intelligence. This alluring picture determined the most eminent representatives of the proscribed school to seek their fortune in Persia. They formed a band of seren, the chicf among them being Damascius and Simplicius, who are known to modern philosophers through some treatises of value which have survived to the present day. ${ }^{1}$ But no sooner had they crossed the Euphrates than their disillusionment commenced. Everywhere criminals were numerous and crime was very imperfectly repressed. Those in authority showed themselves to be pompous and arrogant, and oppressed their inferiors without measure; whilst, although polygamy was permitted, the sexual instinct could scarcely be gratified without the added zest of adultery. Already they felt repentant of their migration, but they pushed onwards until they arrived at the court. There,

1 The commentaries of Simplicius on Aristotle, besides being of consiclerable bulk, are the most valuable of that class of writings which have come lown to us. They have been repeatedly publishert since I 499. 


\section{The Age of Justinian and Thiodora}

indeed. they were received with marked distinction by the the Shahinshah, who condescended to comverse with them affably, and encouraged their attendance on his person. In philosophy, bowerer, they found that he had tasted merely the rudiments, and had never approated the sublimities of their line conceptions. The political vicws common to barbarian monarchs had been in mo way modified by his superlicial knowledge, nor diel it arail to induce cren at semblance of agreement eluring the discussions they helel with him. (hosroes was proud of their apparent homage, and would have retained them with him at any cost, but the ethes of the Orient were insufferable in their eyes, and the party gare the most convincing proof of their sincerity hy declining his generous proposals and electing to return to the precurions life of their native land. At the moment of their departure the peace negotiations with Justinian were pending, and chosroes showed no little magnanimity ly insisting that the treaty should rontain a clatuse granting them the right to occupy their former abodes and to indulge their metaphysical speculations secure from official molestation.'

No leng time clapsed hefore the Shahinshah was consoled for the loss of Damascius and his companions by another byzantine immigrant, who was more fitted to play the part of court philosopher than the cannest Neoplatomists. Aecrtain Uranius, mominally a physician, having skimmed the works of the philosophers, pretended to a profound alepuaintance

"The narrative of his migration for I'ersia is due lo Agathias (ii, 28 ,

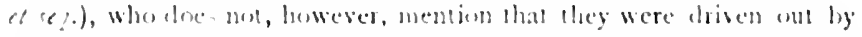
legi-lasion, but represents them mesty as dissativted with the actigion

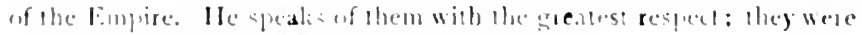

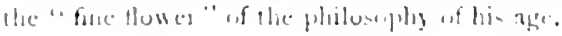




\section{Abolition of the Schools of Philosophy 437}

with them, and made a somewhat unenviable reputation at Constantinople by his garrulous and argumentative disposition, as well as by his usually dissolute mode of life. Having managed to attach himself to Areobindus, the ambassador elect to Persia, he arrived there in his suite, and soon captivated the ear of Chosroes by the glibness of his rhetoric and his pliability in adopting fulsomely the sentiments of the despot. He discoursed with the Magi, and flattered them by admitting that their ontology was in perfect accord with that of the deepest thinkers of the West. Chosroes arowed that he had never met with his equal, and made him the recipient of the unprecedented distinction of sharing his viands with him at the royal banquets. After Uranius re. turned to Constantinople the monarch opened a familiar correspondence with him, and retained him as his intellectual adviser. The glorification of this charlatan at the P'ersian court guides us to estimate accurately the extent of the philosophical acquirements of the Shahinshah, and indicates how far his amateur studies contributed to his mental elevation.

1 Agathias, loc. cit. Quicherat (at alc. Dibbner's Plotinus, Paris, IS55) endeavours to refute Agathias in respect of his low estimate of the intellectual attainments of Chosroes. In the first place he relies on a Syrian MS. discovered by Renan in the British Museum, which is an epitome of Aristotle's Logic, purporting to have been marle by Paul the Persian, a Nestorian priest, for the use of Chosroes. This neutralizes the objection of $A$. that the niceties of Greek philosophy could not be renlered in the rude Pahlavi, it being known that the Shahin hah was obliged to have recourse to translations. Syriac, however, is a language of considerable literary refinement. Further he publishes a MS. - not long unearthed at St. Germains-a Latin version by Scotus Erigena (?) of the solutions given by Priscian, one of the seren, to certain "doubts" entertained hy Chosrnes. The work is incomplete, but nine of the questions which puzzled the monarch are dealt with, viz. the 


\section{${ }_{4} S$ Th: Age of Justinian and Theodora}

The extinction of the Neoplatonists as a religious fraternity followed the compulsory closure of the Mthenian school. The surviving members continued to work in seclusion at their farourite theses, and even produciel some commentaries to which students still resont in order to elucidate the histury of philosophy.' IBut, although Neoplatonism was objectively defunct, the soul of the morement was irremessibly vital, and many of the Catholic ecelesiastics had loms been in secret sympathy with the mystical tenets of the sect. Some of the Christian fathers had been nurtured in the same intellectual atmosphere as the first Neoplatonists, and had sat in the same class-room with Plotinus as hearers of Ammonius at . llexandria. A stealthy admirer of Proclus had adapted his ternary system with great ingenuity to the Christian hicearchy, and produced his theatise as the composition of lojonysius the Areopagite, who was known to have been a companion of St. Paul. The Pygan triads of the Athentan scholarch reappeared moler liblical names, and a long array of Cherul,im, Phrones, Principalitics, Virtues, Powers, Archangels, and Ingels, were ranged in orderly secpuence as a heavenly host proper to intervene:

sull, seep, dreams; the rontine of the seasom, why doclors differ: the lifes: rain and lighong: variation of animal and plants after comwal

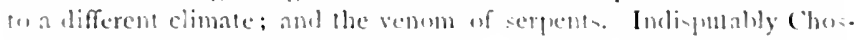

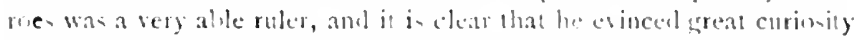

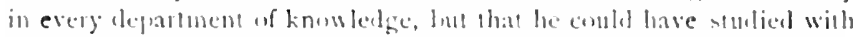
the awiluty nece-ary for the aldamment of coultion is a scarcely

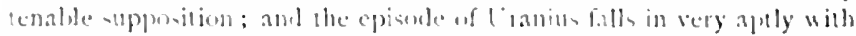
what we hould predicate as likely ter tre the cmecome of his desultors inqui-ilivenes.

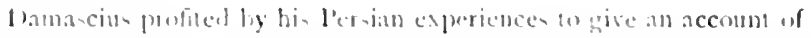

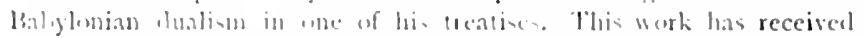

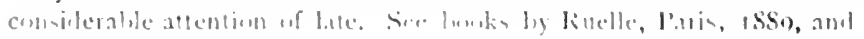

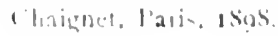




\section{Abolition of the Schools of Philosophy 439}

between the homoousian Trinity and the earth. " The moment Neoplatonism became obsolete as a visible creed, the Greek fathers did not recoil from giring a welcome acceptance to this gorgeous fabric, which in due time travelled westwards to be promulgated among the Gallic churches by the famous Scotus Erigena. Throughout the Middle Ages the spirit of the Alexandrian School was rife among the German mystics, and later even among English Platonists. ${ }^{2}$ Nor scarcely was it repressed in the nineteenth century until the growth of physical science and evolutionary philosophy gave a deathblow to the belief that knowledge could be drawn from our inner consciousness by processes of mental incubation in the closet. ${ }^{3}$

' See Bigg's Neoplatonism, Lond., 189z, for a tahulated synopsis. There were also earthly triaks, which incluled the sacraments and the various orders of priest, etc.

2 Simon and Zeller stop short at the fall of the sehool of Athens, but Vacherot has devoted a third volume to tracing out the diffusion of Neoplatonic ideas in Westem thought throughout the Middle Ages untit recent times. Mystics such as Jacol, Boehme, Nolinos, Madame Guyon, etc. (Quietists), are connected with this stage of the fantasy:

${ }^{3}$ Cudworth, one of the "Cambridge Platonists," is the central figure of this groul. 


\section{CHAPTER VII}

THE INTERNIL AMMINISTRITION OF TIE EMPIRE: INSLRRECTION OF THE CIRCUS FACTIONS IN TIIF CAPIT.II,

THE keystone of Justinian's administration was his 1 lavish expenditure of money. Every enterprise that could engage the attention of a monarch incited him to cmulation, and in arms, legislation, civil reform, public works, and religion, he aspired to equal the achierements of the greatest princes. Hence the persistent need for a wellfilled treasury, and the constant injunction to the Rectors in the provinces. "Above all things apply yoursetves to gathering in the imposts"; whilst the subject is urged by the frequent reminder, "Pay up your taxes promptly, our great undertakings cannot be accomplished without money."

For centuries, as we have already seen," a latent anarchy had prevailed throughout the Empire, hut the evils of such a condition had always been less apparent under a quiescent administration. Moderation of the bureaucracy in the capital save a measure to the proceedings of its deputics in the provinces, and doubtless had a restraining influence, at least that of example, over the rural aristocracy who almost arrogated to themselves at local sovereingty: The considerate,

Nov, viii, S, 10: vii, 1: xxx, 1r, elc.

bee ple los at ? 
thongh firm rule of Anastasius, appears to have reduced to a minimum the most flagrant abuses, whilst his studied parsimony, which led to the accumulation of large reserves, ${ }^{1}$ must have lessened the severity of fiscal oppression. The latter advantage was extended into the reign of Justin, and, while Justinian was dissipating the great funds left by his uncle's predecessor," his reputation for benignancy was not imperilled by rapacity in collecting the tributes. Soon after his accession, however, to undivided power, he found himself without other resource than the property of his subjects for the supply of his financial requirements. Then the maintenance of the exchequer assumed the highest importance in his eyes, and every conceivable device for swelling the revenue was resorted to, while little or no regard was paid to the equity of the means employed. ${ }^{3}$ is an inevitable result all the worst features of the Byzantine political system underwent an exacerbation during the first few years of Justinian's reign. The species of effectivity demanded by the Emperor induced the rise of the most unscrupulous persons to high office; a statesman became the equivalent of an extortioner, and the native venality of the governing class showed exuberant throughout all its grades. Assured of the Emperor's favour as long as he could be noted for his

1 See p. I62.

${ }^{2} \mathrm{Jn}$. Lydus (De Nagistr., iii, $5 \mathrm{I}$ ) confirms the statement of I'rocopius (Anecd., I9) that the immense savings of Anastasius were dissipated during the reign of Justin. He supplies a reison, viz., that the Emperor and his nephew were averse to bearing hardly on their subjects. There seems, however to have been a siuking fund kept up under the name of Anastasius, which continued to exist as a small rescrve; Jn. Ephes. (Smith, Oxford, I 860), p. 358.

3 "He spared no expense, still less did he spare the property of his subjects"; Zonaras, xiv, 6. 


\section{The Age of Justinian and Theodora}

acal in directing the flow of gold towads the treasury, every scrvant of the state grasped at private aftuence by means of illicit exactions, or an overt accessibility to bribes.'

As a consequence of his unexpected advent to power, Justinian was scarcely affected by the prejudices peculiar to monarchs born in the purple; and hence, disregarding conventionalism, he usually chose the most direct and practical methods for carrying out his designs. He was willing on occasion to usurp the functions of any of his subordinates, and, in the selection of his instruments, he promoted the most likely candidates to the highest posts without reference to their rank, seniority, or antecedents. Among his carliest coadjutors in the capital were two remarkable men, Tribonian, a lawyer, and John of Cappadocia, a financier, whose activities became the leading feature in the politics of the age. The former was a native of Pamphylia, ${ }^{3}$ and began his carcer as an adrocate in the praefectural courts of Constantinople. ${ }^{1}$ As Master of the Agentes-in-rebus ${ }^{5}$ he attracted the notice of the Emperor, who soon claimed him as his personal assessor, and raised him to the quacstorship." Tribonian was a man of great learning in the law and an assiduous reader, whence he was led to form a library of legall bouks such as existed in no other custody at the time.

1 "Juminian was insutiable in his lut after goll, and coveted his sulijecti" property to such an extent that he suld them all in a body to his ofticials and tar-collectors"; Lvagrius, iv, 30; cf. l'rocopius, Anecul, 21 at fassim.

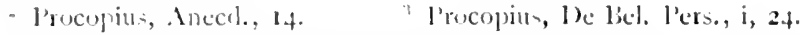

'suidas, sh. nom. Two scparate notices, apparently of the same Tilenian, but there is sume eliscrepancy.

Ie Nis. Cod. Fac. (528), and I be Confim. (529).

Cud., I, xvii, 1; J'rucopius, loc. it.

${ }^{7}$ Conl., I, svii (Timla and Dedit nobin, 17), or I'and., pract. 


\section{Internal Administration of the Empire 443}

He was gifted with a remarkable suavity of manner, and was so artful a flatterer ${ }^{1}$ that, although he had not become a convert to Christianity, and was eren said to be an atheist," Justinian deferred to him as his favourite minister. Tribonian, however, was beset by the vice of avarice, and, though his forensic erudition was invaluable to the Imperial council in relation to the subject, he resorted to it for no other purpose than to make a traffic of justice. His legal decisions were always at auction, and, under ordinary circumstances, his interpretation of the law was fitted ingeniously to meet the requirements of the highest bidder. ${ }^{3}$

The approach to the Imperial tribunal had to be sown with gold before a suitor could advance within sight of an adjudication on his appeal. To pass the sentries who were on guard at the portals necessitated the disbursement of a tangible sum.' Then the attention of the referendary, or attorney who put the case into shape prior to its being submitted to the court, could not be captured until he had been largely bribed." Lastly, the Quaestor had to be satisfied pecuniarily in a ratio adequate to his assessment of the value to the claimant of a favourable decision. Justinian was initiated early in the artifices by which legal chicanery could be made to subserve to undue gains, and became a prime sharer in the profits to be drawn from this

1 Ife affected to live in apprehension that Justinian would be sud. Ienly snatched up to heaven on account of his more than mortal virtue, like Elijah said the Christians, like Romulus thought the I'agans; Procopills, Anecd., 13; Hesychius, De Vir. Illust., 67; Suidas, loc. cit.

2 Ifesychius and suidas, loc. cit. The statement is doubted, but Hesychins was a contemporary.

${ }^{3}$ Procopius, De Bel. Pers., i, 25; Anced., 20; Suidas, loc. cit.

${ }^{4}$ Procopils, Anecd., 14.

Ilict. 


\section{4t+t The Age of Juslinian and Theodora}

mercenary jactitation of the law.' Hence the venality of the Emperor:s Court of Appeal soon incurred obloquy in the capital, and a resentment was kindled among the citizens against his administration.

Vet the ills inflicted on the community loy distorted judgements were slight and partial in comparison with the financial tyranny of John of Cappadocia after he had attained to the rank of Praetorian Pracfect. 1)evoid of literay education, and even inefficient with the pen," this man began his career in an unimportant clerical post under the government." While serving in this capacity he came in contact with Justinian, whose favour he courted with an astuteness popularly supposed to be the distinguishing mark of natives of his province.' Having a singular aptitude for figures, and being extremely ready with expedients for solving any knotty question, he won over the Emperor by liying before him many subtle schemes for amplifying the incidence of the taxes and proportionately swelling the revenue." 'These allurements assured him a speedy promotion to the position of logothete, from which he ascended with little delay to the dignity of an Illustrious, and soon made an easy conquest of the praetorian prefecturc of the East.' Once in the supreme seat of deputed power he had

l'rocopins, Anecel., 14. A referendary named Leem is sail to have thrst opencel hi, eyes as to the feasibility of selling his decisions and to have leagued with him for that purpose. Tribonian seems to have made his chicanery profitable to himsetf alone.

- l'rocupius, De Lel. l'er., i, 24.

In. Lyclus, De Magistr., iii, 57 .

1 livid.

Prueopius, De Bel. l'ers., i, 2.4.

1n. L.ydus, loc. cit., 57 .

Thid. Ife quotes a current epigram to the cllect that "Cappaducians were always bad, worse in office, worst in love of money, and wore than wort if mounted in a grand oflicial chariot." The l'ratedorian 


\section{Internal Administration of the Empire 445}

to justify his elevation to the Emperor by the signal success of his methods: but he was no less intent on making his potent office inordinately profitable to himself.' Every fiscal enactment which had ever passed into law was unearthed from the archives of the Empire, and applied factitiously to compass the transference of the money of the subject to the coffers of the state. ${ }^{2}$ The discovery of a name sufficed for the creation of a claim, and demands were issued for an endless succession of duties, tolls, tallages, censuals, cess, and customs, together with arrearages and apportionments of unpaid imposts, which foreshadowed the reduction of every possessor of property to a common level of indigence. ${ }^{3}$ All persons of means were noted by the agents of the fisc, and called on to pay according to the impression formed as to their resources. No excuses were accepted, protestations of inability were disbelieved, and, in order to meet the case of recalcitrant subjects, a torture chamber was fitted up in a secluded spot of the Praetorium. Here was collected an assortment of chains, manicles, pedicles: instruments of compression for the hands and feet, in short, every kind of apparatus which was suitable for subjecting the nembers to a state of painful strain or constraint. To this den defaulters

Praefect wore a purple robe which only differed from that of the Em. peror by being cut short at the knees. His office was adorned with a golden inkstand, weighing a hundred pounds; Ibil., ii, I3, I4.

1 Jn. Lydus, loc. cit., iii, 62; Procopius, loc. cit.

2 In. Lydus, loc. cit., 66-69; cf. Procopius, Evagrius, and Zonaras, loc. cit. Owing 10 his ignorance of Latin he worked for the abolition of that language in governmental documents. Under Theodosius II, one Cyrus, an Egyptian, being similarly ignorant, attempted the same, but lost the praefecture by it. There was an oracle that fortune would desert the Romans should they forget their native tongue; Jn. Lydus. loc. cit., ii, 12 ; iii, 42 .

${ }^{3}$ Jn. Lydus, loi. cit., 70.

[1.

(F $\mathrm{G}$ 


\section{The Age of Justinian and Theodora}

were hurried, and by means of rackings and suspensions were forced to surrender whatever they possessed unless actually killed by the severity of the torture.' Such was John's method of procedure at his own headquarters, but for the provinces he picked out umissaries of approved brutality, and despatched them into all districts with injunctions to follow his example." Under this regime the Court of Appeal of the Praetorian Prefect was, of course, as venal as that of the Emperor and Tribonian; and the formalities of a trial were almost dispensed with, so that a hasty dispatch of the cases might facilitate the gathering in of the bribes. ${ }^{3}$

'Jn. Lydus, loc. cit., 57. Lydus say's that he himself saw an old man of his acquaintance, who was suspected of having a private hoard, hung up by the hands with stiff ropes until he expired.

2 Ibid., 58. As an instance Lydus describes the conduct of another Cappadocian, nicknamed Maxilloplumacius ("Puffy-Cheeks"), from his peculiar aspeet, who raided Asia for the fise. He began at I'hiladelphia, the native town of Lydus, where he established himself in great state, and indulged himself in unbounded luxury, licentiousness, and cruelty. One Petronius, a man of rank and culture in the town, being possessed of some handsome jewels as heirlooms, was ordered to deliver them up. On his refusal he was loaded with elains, beaten with rods, and shut up in a stable. The l'hiladelphians were deeply grieved and the Bishop was moved to intercede on his behatf. Bible in hand, at the heal of several of his inferior elergy, he appeared before the tyrant, but was at once assailed with foul and abusive language. Ile retired in dismay, but Petronius, at last reduced to despair, promised everything, and, on being let out, took his jewels and other valuables to the Praetoritm, where he threw them in a heap in the restibule. In another case an old soldier was raeked for twenty solidi which he could not pay, but, anxious to be released at any cost, finally asserted that he had them in eoncealment. Being accompanied to his dwelling, and allowed to search apart, after some delay he was found to have hanged himself. The body was then kicked into the street, and the wretehed premises gutted by the apparitors.

Ilid., 66, 67. 


\section{Internal Administration of the Empire 447}

The infamy of the Cappadocian, as an officer of state, was almost surpassed by his mode of life as a private citizen. He rapidly accumulated wealth, and at once applied himself to spend it in gastronomical and libidinous excesses of the most unbridled description. ${ }^{1}$ His first care was to erect a palace of such rastness and magnificence that, in the hyperbolical language of an official of the period, it could only be characterized by the epithets which writers on the wonders of Egypt had applied to the architectural piles reared by Sesostris and the Pharaohs. ${ }^{2}$ In the halls of this resplendent edifice he passed his time in a continuous round of feasting and sensuality, only terminating his orgies with the rise of Lucifer, whilst his attention to business was deferred until the appearance of Hesperus. ${ }^{3}$ Surrounded by a throng of courtesans and debauched youths, he gorged himself with the most costly delicacies until his overloaded stomach ejected its contents over the marble pavements or the persons of those who sat next to him." To glut his appetite the woods of the Euxine were depopulated of their pheasants, whilst the sea was raided for luscious fish to such an extent that, according to the conceit of the same author, the molluscs, expanding their shells to serve as wings, fled through the air instead of through the water, to escape the voracious Cappadocian." As for his religion he made no account of Christianity, but pinned his faith to sorceries

In. Lydus, loc. cit., 62. Procopius, De Bel. Pers., i, 24.

2 Jn. Lydus, loc. cit., ii, 2 I.

3 Itid., iii, 64; but according to Procopius (loc. cit.) he spent the early part of the day in pillaging the citizens, and then flung himself into dissipation. Different periods of his career may be indicated. At first he would be more brisk in making his public appearances.

+ Both Procopius and Lydus notice this addiction to surfeiting.

${ }^{5} \mathrm{Jn}$. Lydus, loc. cit., 62 . 


\section{4t8 The Agc of Justinian and Theodora}

and incantations. If ever he appeared at church he did so in the habiliments of a pagan priest, and ministered to himself with the mummeries of some occult cabbalism instead of following the established ritual. ${ }^{1}$

The appointment of John to the office of praefert of the East took place early in 530, and before the end of the following year his system resulted in producing a state of miscry and destitution throughout the Empire unparalleled in any former age. The visitations of his agents became more dreaded among the rural population than an incursion of barbarians." Everywhere the adacratio of the annones ${ }^{3}$ was carried to excess; and, while money was demanded instead of the contributions in kind as usually accepted, the agricultural produce was often left to perish on the ground.' Injudicious measures of retrenchment were the principal cause of this cril. By a false economy the public posts and the military train were in great part suppressed, with disastrous results. A limited supply of asses was substituted for the considerable number of horses, camels, and mules formerly maintained." Hence, while the department of public intelligence and the commissariat of the army were seriously affected, the farmer also suffered from the greatly lessened demand for fodder. With the crops left unexpectedly on their hands, and the means of carriage almost

1 Procopius, 1)e bel. l'ers., i, 25.

'See p. 160.

$$
2 \text { Jn. Lyilus, loc, cit., } 70 .
$$

'Jn. Lydus, lor. cit., 69.

slizil., 61; Procopius, Anechl., 30. According to the latter the direct route lo Persia was not lampered with. The celerily of some of the couriers ly these posts was remarkable. Of one l'alladius Theo. doiui II ueed lo say that the area of the Empire seemed to be con. Iracted to a small space, he came and went so rapilly between distam frontiers. Ilis time from CP. to the l'ersian border was three days, about 230 miles a day: Socrales, vii, 19. 
abolished, the wretched rustics were driven to despair in their efforts to dispose of their stock. Thus the roads were constantly filled with straggling bands of women, heavily laden, and often with infants at the breast, obliged to cover a long route in order to effect a shipment at the sea-ports; whilst the wayside was littered with the unburied corpses of those who succumbed under the excessive toil.'

Such were the hardships the Byzantine population had to suffer as a consequence of the obligations imposed on them directly by the Imperial government, but these were largely aggravated by their being forced to minister to the private needs and even lustful passions of all those in power throughout the Empire. Every impost was augmented by an overplus which went into the pocket of the agent who exacted it or through whose hands it passed. The Rector of the pro vince, gencrally an impecunious aspirant to place and fortune, had paid a large sum to the bureaucracy, and borrowed it at usury, for the bestowal of his codicil. ${ }^{2}$ He proceeded, therefore, to his local seat of power accompanied by a body of creditors to whom he had guaranteed the liquidation of their claims out of the revenue of his vicegerency; ${ }^{3}$ and he had, moreover, to make a provision from the artificially swollen taxes against the time when he hoped to retire from office into a position of leisured affluence. ' When an army passed

1 In. Lydus, loc. cit., 70.

"Nov, viii, praef., I I, etc.

3 "All can see that he who buys his office for gold, and that money borrowed at usury, must be beset by many whom he is obliged to satisfy from his province so that he may be liberated from debt," Ilid. "They (the Rectors) had to be rapacious and have but one thought, to satisfy creditors following them and threatening them on all sides. Thus our subjects have been sold," etc.; Nov. xxviii, 4.

" "I Ie must also think of putting by something for the future when no longer in office"; Nov. viii, pracf. 


\section{The Age of Justinian and Theodora}

through a district, not only were the soldiers quartered on the inhabitants, who for the time being were expelled from their proper dwellings, but contributions for the support of the troops were levied under every sort of false pretence, even by persons who had no authority whatever to collect funds for the commissariat.' 'To all this was added the constant oppression by the local magnates of their weaker neighbours, whose lands they seized, advertising by noticus fixed to the ground that they assumed them as their own property." At the same time the owners were claimed as surfs, bound for the future in service to an overlord. ${ }^{3}$ In the main these proceedings were quite arbitrary, and differed in no way from professed brigandage, but as a rule they were conducted under the shadow of legality by giving them the form of distraints or evictions in respect of money lent.' Attended by a numerous body of armed retainers the wealthy landowners made a descent on the coveted bomestead, plundered the household, drove off the cattle, and abducted wives and daughters for the purpose of concubinage." But not in all cases without resistance being

1 Nuv. cxxx; cf. cxxviii; l'rocopius, Anecl., 23, 30; In. Ljolus, loc. iit., $6 \mathrm{I}$.

? Cod., II, xiv, w, xvi; Nor, xvii, 15, cle.

"Cod., XI, liii; Nur. xvii, 13, 14, etc.; see p. 202.

"Nos. xxxit; xxaiii; sxxiv. "On account of the avarice of creditors who aluse the povert) "f the limes (535) and acquire the allotments of the unfortunate peasant, retaining all their property in return for a litule sustenance, we enacted," ctc. This (Nov. xxiii) is addressed to the l'raetorian Praefect of Illyricum, an official seldom heard of, who eems to have been almost destitute of prolitical influence as compared with his potent colleagte of the East.

" "We are almost a hamed to refer to the conduct of these. Nen of greal posecsions, with what insolence they range the country; how (he) are served ly guarts, so that an intulerable crowd of men follow them; how daringly they pillage everybody, anung whom are many 
offered; where such attacks were anticipated, the small farmers prepared for them, and with the aid of the local peasantry joined battle with the raiders. Thus the provinces were almost constantly the scene of a miniature warfare. ${ }^{3}$ In the midst of these disorders the Rector held the balance of justice and inclined the scale towards whoever weighted it with the heaviest bribe. Often, in fact, he was himself one of the worst offenders; and in his capacity as collector of the revenue, or under the pretence of giving police protection, he plundered and committed outrages in every direction throughout the country. ${ }^{2}$ And in such licence he was

priests, but mostly women," etc.; Nov. xxx, 5. "What can be more trying than the driving off of oxen, horses, and cattle in general, or even (to speak of small matters) of domestic fowl . . . whence a multitude appeals to us here (CP.) daily; men, women, hustled from their homes, in beggary, sometimes to die here"; Nov. lxix, I; cf. Edict viii.

${ }^{3}$ Nov. xvii, 2; 1xxxv, passim; Edict viii, praef, etc.

"The conduct of Rectors is often described in detail. "They dismiss many culprits, selling to them their offences: very many innocent people they condemn in order to benefit obnoxious persons, and not only in money actions, but in criminal cases"; Nov. viii, praef. "We hear how unjustly the provincial judges act for the sake of lucre, declining their duties as to wills, attestation of facts, marriages, settlements, and even burials" (without bribes); Nov. cxxxiv, 3. "He abstained from no sort of actual depredation, plundered towns and returned to this happy city loaded with gold, leaving the region in the utmost poverty"; Edict xii. Also by giving a licence to agents: "They are not to despatch 'pursuers of brigands' or 'inhibitors of disorder,' rather to be called thieves and rioters who, using the occasion as a cloak, are guilty of the worst excesses"; Nov, viii, 12. "As to curators and tractators, we abolish the very names, looking back to the injuries they have inflicted in the past on the wretched tributaries"; Nov. $x x x, 2$. Another expedient was to plant deputies (vicarii, loci servatores, romírnpres) in every part of his province, to whom the Rector delegated his full powers, thus becoming a hundred-handed Briareus to rack the provincials; Nov. viii, 4; xvii, Io; cxxxiv, I; Salvian, writing in the West, c. 450, complains that the Rector commits himself every crime which he sits to 


\section{Thi Age of Justimian and Theodora}

usually afforded countenance and example ly the logothetes and other afficers, who were superior to him in authority, during their special visitations as agents of the fisc.' 'These hampies resorted to every imaginable device for embezhling money, and especially ly presenting long bills to the decurions for public works which were never executed." They also invented legal pretexts to commit ontrages on the families of the delitors, and wives, virgins, and youths were regularly debauched by them." In some localities eren the collection of the tributes was regularly opposed and attended with bloodshed.' As for convicted crimimals, eren they could] fed no assurance of having to suffer only the statutery punishments, but according to the temper of the judge they had to undergo a penalty, and hands and feet were lopped off contimually, with litte or no regard to law or humanity."

punish as a judge; nud. what he thinks cren wotse, continues in the same courses after he has retired into the pusition of a rich and pewerful private citisen: I) Gubernat. Dei, vii, 21 . For the benefit of rearlers not familine with the Corpus Juri Civilis I may mention that in refer. ring 10 "Nowed " I am queting Justinian's own words, or al least the Act-composed uncler his eye. But owing to the verbosily of the original I am rometimes olliged to comlense.

Sice pp. 158 it se 195 it si\%.

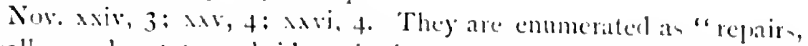

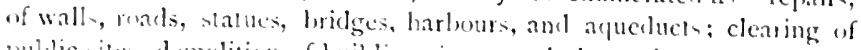
pullic siten, demolition of building improperly located, and laying val

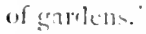

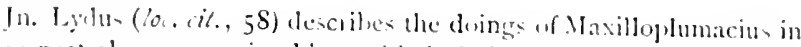

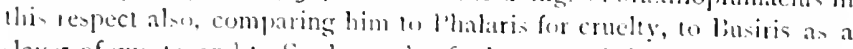

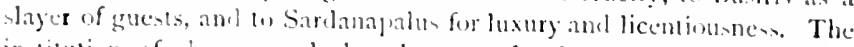
intitution of lavery and the absence of a llateas Corpun under a

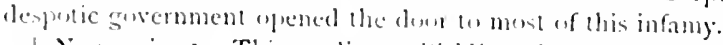

Nov a ais, 1. This applies te lividia, where the natives are char.

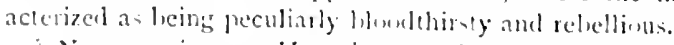

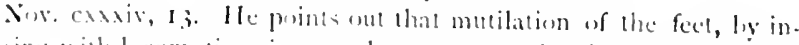
tedfoing with licometion, is a much everer penalty than removing the 


\section{Internal Administration of the Empire 453}

All the evils and abuses of the Byzantine system were magnified and multiplied by the ruthless policy of John, and at Constantinople the widespread discontent began to show signs of tending to a crisis. Every class was more or less affected, and the numberless sufferers were increasingly associated in the capital. Advocates went without employment, since it was considered useless to protract trials by pleadings or the examination of witnesses. ${ }^{1}$ 'The shipping interest was ruined by the imposition of onerous port dues and the establishment of custom-houses at the approaches to the city, both in the Hellespont and the Bosphorus. ${ }^{2}$ As a result numbers of those engaged in maritime commerce burnt their vessels, and a shortage of foodstuffs distressed the inhabitants. ${ }^{3}$ At all times the briskness of trade was sapped for the mercantile class by the privileges granted to the religious orders and their abuse of the concessions. Not only were there eleven hundred shops free of excise belonging to St. Sophia, ${ }^{t}$ but all other churches, as well as monasteries, hospitals, poorhouses, and orphan homes, claimed a like immunity. Nor did the list end even here, for the three grades of nobles arrogated to themselves an equal right to trade with remitted taxes.

The Blue Faction were favoured by Justinian and his consort, who accorded them such indulgence that they considered themselves to be above the law. Their affiliation to the throne caused them to enjoy great credit among the ordinary citizens, wherefore they decided to distinguish themselves objectively by adopting a peculiar uniform.

hands and forbids it (against Constantine, who ordained it in the case of fugitive slaves; Cod. VI, i, 3).

1 Jn. Lydus, loc. cit., 66.

3 Ibid.

1 Nov. xliii.

2 Procopius, Anecd., 25.

5 Ibid. 


\section{5t The Agr of Justinim and Theodora}

Thus they discarded the use of the razor and wore full Persian beards, allowed their back hair to grow long, in imitation of the Hums, and domned richly embroidered tunics furnished with slecres which bellied out in an extraordinary fashion from the wrist up to the shoulder. Secure of impmity for any exesses they might commit, the more vicious members carried weapons day and night, ostensibly for the purpose mercly of chastising their sworn encmics, the Green faction, but in reality with the intention of robbing and murdering peaceful inhabitants. Under the pretence of carrying on their historical feud, they assassinated in the strects, despoiled private houses of their valuables, and even outraged wives and daughters. Similar enormities on the part of the Greens were severely dealt with by the magistrates, hut they were terrorized by the dominant Faction into ignoring their misdeeds. Those who delied the malefactors by acting impartially paid for their integrity with their lives. The better spirits of the Blue 1) eme bewailed the lawlessness of their fellows, and the Emperor made fitful efforts to repress the disorders, but 'Theodora resisted any' attempt to restrict the licence of her favourite clan.' Numbers of the Greens were driven from their homes by the ceaseless persecution, and, finding themsclves everywhere in discredit, avenged their wrongs on society in general by taking to the road and practising brigandage by the most merciless methods. In a lesser degree crery city of the Empire presented a scence of confusion similar to that which reigned at Constantinople.

I'recopius (. Anecd., 7, 10) i, the authuily for all these details. I every esential point he is cormolurated hy Evagrius, iv, 32.

- Fingriu, lo. itt.

IBoth I'rocopius (Ancel., 17) and Esigrius (10, att.) mention the 


\section{Internal Administration of the Empire 455}

Into a capital thus agitated by numberless grievances of its own, a varied crowd of fugitives from the provinces began to pour, in the autumn of 531 . Their proper abodes had been made uninhabitable for them, and they fled in terror from the local tyrants to seek redress at the hands of the autocrator. Peasant farmers with their wives, priests, monks, and nuns, often accompanied by their lawyers, thronged the city as they pressed onwards to lay their appeals at the foot of the throne. ' They clamoured incessantly in all the public places, so that to meet the emergency it bccame necessary to revive a number of forgotten magistracies, praetors and quaesitors, ${ }^{2}$ who might hear complaints and appease the rising tumult. On all sides the populace reviled the bureaucracy who had brought about such an impass, and, as the old year went out, a general feeling prevailed that the existing order of things must come to an end. ${ }^{3}$

case of Callinicus, governor of Cilicia, who was impaled for vindicating the law by the execution of two murderers of the Blue Faction. Procopius (Anecd., 29) also recounts an émeute at Tarsus, in which the Blues were the principals. In both these cases the part of violent vengeance was played by Theodora. Evagrius lies under the suspicion of having read the Anecdotes of Procopius. If so, the fact that he makes no protest against the picture there given of the Empress proves his belief in its truth. In a parallel case he strongly defends Constantine against the strictures of Zosimus; iii, 40, 4I. Zonaras also seems to be influenced by the work. Indeed it is difficult to see how he could have avoided knowing it since it was familiar to "Suidas" before his time.

${ }^{1}$ Jn. Lydus, loc. cit., 70; cf. Nov. xxiv, 2; xxv, 3; xxx, 9; cxxviii, praef.; cxlv, praef. Most fully in Nov. lxxx, e.g., "We find that the provinces are being gradually lespoiled of their inhabitants; our great city here is populous with crowds of diverse men, chiefly farmers who have left their townships and lands." Also specified as men, women, clerics, monks, nuns, and advocates of outlying places.

${ }^{2}$ Jn. Lydus, loc. cit., 70; cf. ii, 29, 30; Nov. xiii, 1xxx.

3 Jn. Lydus, loc. cit., 70 ; Zonaras, xiv, 6. 


\section{$+5^{6}$ \\ The Age of Justinian and Thoodora}

With the opening of Jamuary, 532, the season of the Consular Festivals was at hand, but both in this year and the previous one ardour for parade had been deadened hy political distraction, and the appointment of a consul was passed over. Preparations were made, howerer, for a display in the Circus, and it was hoped that something of the deepening gloom might be lifted by the diversion thus afforded. But the result disappointed expectation, and the assembly of the people in the vast area provided an opportunity for the actively smouldering discontent to work its way to the surface and to hurst into flame. The possibility' of the thronc becoming vacant had been brooding in the minds of the lactions, and, as usual, when confronted with that contingency, there was a tendency to a temporary accord between the blues and Greens." On a Sunday, the eleventh day of the month, Justinian, with the customary pomp, took his seat in the Cathisma." A protest against the administration had been previously concerted, and the (ireens, as being frankly discountenanced by the Emperor, were most forward to evince their hostility. At first a respectful tone was adopted, and the Autocrator was acclaimed with the usual formulas, "Many years to Justinian Augustus! May you be victorious!" The Greens then raised a cry that the people were oppressed, and prased to be delivered from their sufferings. A heated dialogue between the throne and the demagogy then ensued, which ended in bitter recriminatiuns passing from side to side. On such occasions the Emperor made use of an officer called a Mandator as his

1 See p. 303.

- by a comparison uf Jn. Malala (xviii, p. 473) and Theo. phane (atn. 6,024), the fact of the day being a Sunday can be te. cruninesl. 
mouthpiece, whilst the Demarch acted as spokesman for the Faction concerned. At the outset one Calopodius was named as the object of complaint, doubtless the executive officer of the Praefect of the City, whose brutality in preserving order had awakened the resentment of the masses: $D$. "I am oppressed; I can bear it no longer, God knows." $M$. "Who is in fault? we know of no one." $D$. "Thrice August, I fear to name him." $M$. "Of whom do you complain? We have no idea of the person meant." $D$. "Naster of us all, it is Calopodius the centurion.".$M$. "Calopodius is not in authority." $D$. "May the lot of Judas be his! God will pay him out." $M$. "You have come here to insult the magistrates, not to look on at the games." D. "I say, may he suffer like Judas!" MI. "Hold your tongue, Jews, Manichaeans, Samaritans!" D. "Oh, you call us Jews and Samaritans! Holy Virgin, be with us!" $M$. "I do, and bid you all to get baptized in the name of the One." $D$. "Oh, bring the water; let us be baptized as you say." $M$. "I will have your heads cut off." $D$. "Oh, we must not speak the truth for fear of losing our heads. Take no offence, Emperor, I have some right to liberty." $M$. "Rascals, will you risk your lives?" $D$. "Would that Sabbatius had never been born! Then a son of his would not have been a murderer. Who killed the wood-seller at the Zeugma?" M. "You killed him." D. "Who killed the son of Epagathus?" M. "You killed him also, and you say the Blues did it." So far the Blues had maintained a sullen silence, but at this suggestion some of them were roused to taunt the Greens. Presently' the latter all trooped out of the Circus, exclaiming, "Goodbye to justice! We will turn Jews; better to be a Pagan than

1 This taunt evidently means, "You are not fit to be Christians; abandon the Trinity and join the infidel monotheists." 


\section{${ }_{45}$ The Age of Justinian and Theodora}

a Hlue." 'Thus Justinian and the Blues were left alone at the performance.'

In the evening of the same day Justinian determined on an effort to quell the sedition by making an example of those who had been most insolent to him in the Hippodrome. Seven persons, drawn from both factions, were seized by Eudaemon, the Praefect of the city, and led off to execution. Four were decapitated and the remaining three were hung: but in the case of two of the latter the rope broke, and the culprits fell to the ground. At the sight of this moving accident the bystanders were greatly agitated, and an outcry for pardon arose, whereupon some monks interposed and carried off the men by boat to the monastery of St. Laurence. One of those rescued was a Blue, the other a Green; and the circumstance caused the union between the factions to be more firmly cemented. On hearing of the rescue, Eudaemon placed a guard of soldiers outside the sanctuary, but did not dare to violate it. ${ }^{2}$ On the following 'Tuesday the spectacle was resumed in the Circus, and, during the whole time of the exhibition hoth factions clamoured conjointly to the Emperor for the release of the prisoners, intermingling cries of "Long years to the wretched Blues and (ireens," with their prayers. But Justinian remained sternly irresponsive, and the assembly had to disperse without receiving any indication of Imperial sympathy."

This dialogue exists only in Theophanes (an. cit.), but is alluded to in Chron. Pasclal.; an. 532. I have only sampled it, as, beyond the animosity shown on each sille, there is little pregnancy in $i t$, and the whole would be merely tedious to the ordinary reader. It has often been translated at length, by Isambert, Hodgkin, Bury, Diehl, etc.

'Malala and Theophanes, lec. it. According wo the latter they were strung up a second time, and again fell.

3 It. Malala, P. $47+$. 
The popular rancour now rose to fever-heat, and the leaders of the Demes counselled extreme measures. In order that all who were on the side of the insurgents might have a means of recognizing each other, the device of a countersign was adopted, and the word Nika, that is, "victory," was chosen for the purpose, whence the movement was known ever afterwards as the "Nika revolt." " First a rush was made to the Praetorium of the City Praefect to demand the removal of the guard from the monastery, but no answer could be obtained. At this moment a slight concession might have appeased the rage of the multitude, so that the ferment would have been modified for the time. Obduracy, however, inflamed their passions beyond measure, the Praetorium was set on fire, and an irruption was then made towards the Augusteum with the object of assailing Justinian himself. A number of soldiers encountered on the way were butchered by the mob, ${ }^{2}$ firebrands were hurled into the Chalke, and soon the external chambers of the palace were all in flames. The conflagration spread rapidly, the principal buildings in the square became quickly involved, and during the evening the Baths of Zeuxippus, the Senate House, and the great church of St. Sophia were reduced to a heap of smoking ruins. $^{3}$

On the following day the rioters came out early in greatly increased numbers, and all those who had previously been disaffected to the government now ranged themselves openly against it. At the same time people of every class who wished to stand aloof during the rebellion fled from the city

1 Procopius, De Bel. Pers., i, 24; Malala, loc. cit., etc.

2 Theophanes, loc. cit.

${ }^{3}$ Malala and Theophanes. loc cit. ; cf. Procopius and Chron. Paschal., loc, cit. 


\section{t6o The Age of Justinian and Theodora}

and hid themselves in places of siffety on the opposite continent.' 'The lemarchs convened a meeting in the formm of Constantine," where they were joined by a considerable body of nobles and semators. The ministers were denounced, the deposition of Justinian was agreed upon, and it was resolved that lrobus, one of the nephews of Anastasius, should be proclaimed as Emperor. With the multitude surging after them the leaders then procecded to the bouse of that greneral, which was situated near the harbour of Julian. His presence and aceeptance of the dignity was clemanded, whilst, as he was known to possess a private arsenal, cries arose from the throng that they should be supplied with arms. l'robus, however, was found to have disappeared, and, on ascertaining the fact, the mob set fire to the premises and retired." Simultaneously heralds were ammouncing, on the part of Iustinian, that the games in the Hippodrome were to be continued; but the populace responded by injecting fire into the arena, and refused to enter, exclaiming that he merely wished to catch them in a trap.' The leaders were now at a loss what step to take, for Iypatius and Pompeius, the two other nephews of Anastasius, were not only helieved to be loyal to the Emperor, but were actually on duty as memhers of his staff within the palace. The general concourse, however, did not hesitate as to how to act, but yielded to their lust for revenge, and rushed off shouting, "lown with Tribonian, John of Cappradocia, and Eudaemon," determined to seck them out and lynch them as soon as they could be found.

The Emperor now became anxious as detailed information

1 Prucopius, loc. cit.

$\therefore$ lliil.

Chron. I'aschal. and Theophanes, locit.

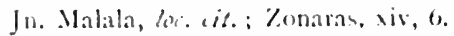

Procopius, Malala, and Chrom. Panchal., lot. it. 


\section{Insurrection of the Circus Faclions $46 \mathrm{I}$}

cante in as to the havoc already wrought in the capital, and he began to realize the extent of the defection. The wild uproar, harping incessantly on a special note, reached his ears, and he sent an officer to ascertain what the people were vociferating. ${ }^{1}$ Is soon as an answer was brought to him he decided to yield, hoping that conciliation would induce an immediate calm. The three obnoxious officials were displaced from their posts, and others, popular for their wellknown integrity; were appointed in their stead. Effective measures were taken to announce the change publicly, but the concession failed to appease the tumult." The provisional government of the insurgents felt that they had gone too far to retreat with safely, whilst their secret emissaries had already been at work endeavouring to entice Hypatius from the palace with the promise of his elevation to the purple.

During the next three days the devastation of the metropolis continued, and Constantinople assumed the aspect of a city taken by the enemy. ${ }^{3}$ The only hope for the government now lay in its being able to suppress the revolt by force, but the Byzantine soldiery showed signs of disaffection, and it was recognized that even the Excubitors, of whom Justinian himself had held the command, could not be trusted." Within the precincts of the Palace there was, however, a considerable body of barbarian mercenaries, as well as several of the Imperial generals who remained loyal

${ }^{1}$ Chron. Paschal., loc. cit.

${ }^{2}$ Procopius, Malala, and Chron. Paschal, loc. cit. The new Praetorian Praefect was named Phocas, whose excellent character is eulugized by Procopius (Anecd., 21), and especially by Jn. Lydus, De Magistr., iii, 72.

${ }^{3}$ Procopius, loc, cit.

Ibid.; Chron. Paschal., loc. cit.

II.

$\mathrm{H} \mathrm{H}$ 
and were ready to act against the rioters.' (On the 'Thursday belisarius issued forth with a body of (joths and Ilerules, and a fierce battle ensued around the Milium and in the adjoining streets. 'The rebels defended themselves furiously, and, while the men fought below, women, posted in the upper chambers of the houses, hurled stones and tiles through the winduws on the heads of their military antagonists. Numbers of these Amazons were amoner the slain.' It a certain hour of the day an attempt was made to restore order by priestly intervention, and a train of ecclesiastics, presenting the sitered books and holy images to the eyes of the combatants, descended into the seene of the conflict. The byzantines might have been influenced, but the barbarians took no account of their presence, and the strife raged without abatement.' The civil war in the streets was continued for the wo succeeding days, ineffectirely on the part of the authorities, while the confidence of the insurgents increased. The work of incendiarism went on, and now on both sides, for the soldiers tried to dislodge those who assaliled them from the domiciles and public edifices by firing the buildings." The wind often assisted the conflagration by sweeping the flames along." Among the architectural monuments consumed during this period of the sedition were the Octagon," the church of St. Irene," the Huspital of Sampson

1 Procupius, loc cit, etc. About j, 000 barharian soldiers, accourding wo Theophane, loc, itl.

- Jn. Malala, p. +75 ; Zonaras, loc. it.

3 Chron. I'aschal. and Zonaras, loc. cit.

Lonaras, loc. itt.

Chron. Paschal, loc, it.

Chron. Paschat. and Zonaras, loc. it.

Chron. Paschal., loc cit.

Itid., Theophanes, 106. it.; see p. 58 . This building was burnt ly the military.

livil.; see p. $5^{6}$. 


\section{Insurrection of the Circus Factions}

with its infirm inmates, 'the House of Lamps with its rich wares, ${ }^{2}$ the Palace of Lausus with its irreplaceable art treasures, ${ }^{3}$ and the porticos ranging between the Augusteum and the Pavement.'

In the meantime Justinian and the Imperial party within the Palace began to despair of their fortunes. The Excubitors and the other corps of domestics did not break into open mutiny, but their faces appeared lowering and indifferent, and it was evident that their sympathies were veering steadily in the direction of the rebels. That the insurgents were intent on replacing him with Hypatius was well known to the Emperor, and he became apprehensive lest at any moment his own guards might consummate their wishes by the seizure of his person and the proclamation of his rival. ${ }^{5}$ He summoned the nephews of Anastasius to his presence, and urged them to leave the palace in order to safeguard their own households. They protested that it was their duty to stand by their sovereign in such a crisis, but he suspected their loyalty and insisted peremptorily on their departure. They obeyed with reluctance, and quitted the

1 Chron. Pascal., loc. cit.; see p. 56.

- Cedrenus, i, p. 6.48; see p. 58. He and Zonaras repeat, of course, for the most part what has been said by earlier writers.

3 Theophanes, loc. cit.; see p. 68 .

${ }^{+}$Procopius, loc cit., etc.; see p. 68.

Narcellinus Comes (an. 532) dwelts on this aspect of the insurrection. In his view it was all a conspiracy of the three brothers, who had bribed the seditious elements of the populace; they were dissimulating within the Palace, etc. Jn. Lydus (loc. cit.) alone shows how the revolt originated from the congested malcontents in the capital, but Zonaras gives an inkling (loc. cit.). M. C. was long associated with Justinian as the officer (cancellarius) of his legal court (Cassiodorts, De Inst. Div. Lit, I7) and his account was probably inspired by the Emperor as most politic. 


\section{+6.t The Age of Justinian and Theodora}

Court on the Sitturday crening." It the sime time Justinian, anticipating that a successful assault might be made on the l'alace, heaped all his most precious possessions into a swift galley, which lay in the Imperial harbour, and held himself in readiness for a precipitate flight to the 'Thracian town of Heraclea."

Early on Sunday morning the limperor resolved on mating a final effort to win back the allegiance of his subjects. ly assuming an attitude of contrition, and proving his sincerity by a promise of universal ammesty, he might yet be able to save his throne. Holding the (rospels in his hand, he proceeded at dawn to the Hippodrome, and established himsell in the regal seat. A proclamation was made, and the people, now confident in their own strength, came flocking in on all sides, attracted by the belief that something umusual was ahout to take place. Iustinian advanced, and protending the sacred volume, adjured the assemblage: "ly" the might of this hallowed Word I condone everything that has happened. None of you shall be arrested; only be paciliced. My sins have brought about this impass; no blame attaches to you. On me the guilt for not answering your appeal for mercy." Murmurs of approval were hearl for a moment, hut a general hooting quickly drowned them, and loud cries of "Ass, thou liest!" were repeated by a myriad of roices." Finally the tumult resolved itself into persistent calls for Iypatius. The Emperor persevered no further, but retired in silence to the Palace.

The news spread rapidly that the disinherited princes

I'rocopius, loc. cit. Most probably, hut according (o) ('mon. l'aschal. (10i. it.) it was the next morning.

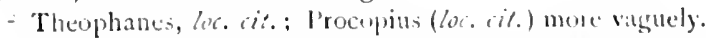

Chron. I'aschal., loi. wit.; with less detail ly Malah, p. 475. 


\section{Insurrection of the Circus Factions 465}

were at liberty, and the revolutionaries immediately thronged to their residence. Hypatius was demanded, and in despite of the outcry of his wife, who foreboded disaster, was forced along to the Forum of Constantine. There the usual forms of a coronation were enacted; he was hoisted on a shield and crowned with a golden necklace. Exulting in this achievement, a wave of excitement swept over the crowd, and all clamoured that the new Emperor should be borne in triumph to the Circus and installed in the Cathisma, whilst a determined effort was being made for the capture of the Palace. A senator named Origen protested warmly against this move as being too rash and hasty. "Have patience for the present," said he, "let us fortify ourselves in another palace, of which there are several in the city. Whilst his resources are being frittered away, Justinian will be tired out and fly of his own accord; or at some opportune moment we shall be able to take him without risk." His prudent counsel was, however, cried down; Hypatius was hurried along reluctantly, and compelled to usurp the Imperial seat, whilst the people thronged the arena and acclaimed him with reckless enthusiasm.' But he contemplated his sudden rise with dismay, and felt profoundly insecure in his new position. Taking his opportunity, he privately despatched a Candidate to assure Justinian that he was involuntarily acting a part, and was only too anxious to repudiate the unwelcome honours thrust upon him. In a short time his messenger returned with a joyous air; as he strove to enter the Palace, the chief physician had accosted him: "Where are you going," said he, "there is no one

1 The coronation, etc., of IIypatius is told most circumstantially by I'rocopius (loc. cit.), but some further details are in be found in the briefer accounts of the later chronogiaphists. 


\section{The Age of Justinian and Theodora}

within, the Emperor has taken his departure." "Master," evelaimed the Candidite. "God wishes you to reign ; Justinian has fled and the Palace is empty:" At this announcement Iypatius resigned himself with some confidence to his fortune.' The populace went on applauding him tumuluously, whilst they were loud in their vituperation of Iustinian and Theodori."

The report that Justinian had virtually abdicated by abandoning his post was filse, but the author of it may have supposed that he was speaking an imminent truth, as that erent seemed on the point of being realized. Hesitating (1) commit himself to the irrerocable step, the Emperor paused to throw a last glance at the situation. He initiated a debate, but his advisers were despondent, and their opinions hali-hearted and divergent. Of all those concerned 'Theodora felt most deeply the ignominy of flight, and, umable to restrain her indignation at their halting resolution, burst into a passionate remonstrance. She deprecated the assurance of a woman in presuming to address a body of men, and pleaded the exigences of the moment as her "xcuse. "Even at this adverse crisis," said she, "I think the alternative of flight is out of the question. 'Though he may be permitted to lire in safety as an exile, the master of an cmpire should not survive the loss of his dignity. As for myself, may I nover live to see the day when this purple mantle shall fall from me, and penple no longer sahute me as limpress. I hold no sentiment so dear as that old saying. - Royalty is a fune thing to be buried in."

Chrom. l'aschal., lire cit.

- Mili. : Theophanes, loi, cit.

The eximinas conduct of Thendura on this accasion is known to

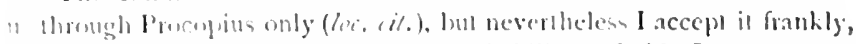

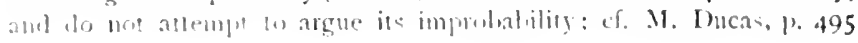




\section{Insurrection of the Circus Factions}

By this bold speech Theodora infused her own intrepid spirit into the Imperial party. No longer wavering in their counsels, they resolved to assume the offensive, and thought only of how to strike with most effect at the usurper and the rebels who supported him. The barbarian mercenarics eongregated in the Palace still amounted to three or four thousand men, and several reliable officers were at hand to lead them. These troops were divided into two brigades and placed under the command of Belisarius and Mlundus the Goth respectively.' At the same time Narses, the Chief Eunuch, opened negotiations with the Blue Faction, and by extensive bribery succeeded in detaching a large number of them from their associates. Some dissension in the Hippodrome resulted, voices were raised in favour of Justinian, and Hypatius was no longer the object of unalloged enthusiasm. ${ }^{2}$ And now Belisarius, supported by his colleague, determined to make a direct onslaught on the Cathisma, which was crowded with the improvised guards of the newly constituted emperor." He essayed to pass by the Cochlea, but found the way blocked by the Exenbitors, who had adopted a neutral attitude, and decided to be deaf to all orders as long as the fortunes of the rival parties hung in the balance. Seeing that any effort in that direction would be futile, he abandoned the scheme and, somewhat disheartened, returned to consult Justinian. A different plan of attack was

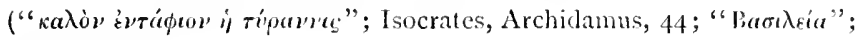
Procopius).

1 Procopius, loc. cit.

In. Malala, p. 476; Chron. P'aschal., loc. cit., etc. Procopius seems to know nothing of the part played by Narses, aluhongh he was possibly in the Palace with Belisarius all the time.

3 Two hundred and fifly of the (ireens, armed and mailed; Chron. Paschal. and Theophanes, loc cit. 


\section{t68 The Age of Justinian and Theodora}

then concerted with Mundus. Both generals made their way out with some difficulty over the ruins of the Chalke, and drew up their men in a compact body in the Augusteum. Marching around from thence they inspected all the inlets of the Circus, but saw that those on the north were held in force by the armed adherents of Hypatius. On arriving at the sphendone, however, Belisarius noticed that the way lay open into the arena, where the unarmed mob were collected in a dense throng. With a sudden impulse he called his men to arms and rushed on the crowd with rengeful determination. A remorseless massacre followed, and was continued as long as the barbarians found any living being within their reach. As for Mundus, the moment he perceived how Belisarius had become engaged, he swept rapidly round the southern circuit of the Ilippodrome and made a similar irruption through the opposite entry, that called the Gate of the Dead. The doomed people, thus caught between the two brigacles of infuriated troops, were cut off from all chance of escape; and, when at length the slaughter ceased, it was computed that at least thirty-five thousand citizens had been slain in this military execution. ${ }^{1}$

At the sight of the massacre consternation seized on the immediate partisans of Hypatius, and their confident union was completely dissolved. All felt that the cause of the upstart emperor was lost, and thought only of falling off from his perilous proximity in order to ensure their individual safety. A corresponding sense of assurance quickly spread among the inmates of the Palace as soon as they becance aware that the rebels massed in the Hippodrome were undergoing extermination. Iustus and Boraides, two

Procopius, 106 rit.; some of the others make it more. 


\section{Insurrection of the Circus Factions}

young relatives of Justinian, ${ }^{1}$ seeing their opportunity, placed themselves at the head of a small body of faithful guards and made an impetuous rush to the Cathisma. No one ciaring to withstand them, they ascended at once, seized on Hypatius and his brother, and hurried them before the Emperor. They were submitted to a brief examination, during which Hypatius maintained a dignified attitude, and asserted his consistent loyalty, asseverating that they had merely acted under popular compulsion. On the other hand, Pompeius, a man less experienced in affairs, broke down utterly, and abjectly bewailed his misfortune. Justinian remanded them in custody, and consulted with his ministers as to their fate. ${ }^{2}$ He suggested clemency, but the Empress intervened with her usual rehemence, and insisted on the infliction of the death penalty. ${ }^{3}$ She bore down all opposition, and next morning they were handed over to the soldiery, who executed them and threw their bodies into the sea. Their property was confiscated to the state, as well as that of the other men of rank who had associated themselves to the Nika, but after a short time a partial restitution was made to their families.' That Jus-

1 Procopius, loc. it. Generally assumed to be nephews of Justinian er fratre ignoto. Procopius alone seems to know of the assistance they rendered, or the exact details of the attack in general.

"Jn. Malala, loc. cit., etc. They are represented as pleading, "Master, we designedly massed your enemies into the Hippodrome," to which Justinian replies, "You did well, lut why not before the cily" was consumed by fire?" As all the damage was done while they were still in personal attendance on him, this taunt seems illogical.

${ }^{3}$ Zacharia Myt. (ix, I4) is the only one to mention Theodora's implacability. "She became enraged and swore by God and him (J.)," etc.

- Procopius, 10i cit., etc. According to Chron. Paschal., the hody of Hypatius was llurown up again, and Justinian ordered it to be buried 
tinian, though often serere, and even reckless in punishments, was not vindictive, is shown by an incident which nccurred in connection with Probus, who just escaped being involved in the insurrection. A few years previously he was accused of treasonable utterances against the Emperor, whereupon a court of incluiry was held, at which the charge was brought home to him. The fincling of the judges was delivered in writing to Justinian, but he, tearing up the document in the presence of the delinquent, said, "Probus, I forgive you: pray to God that he may do likewise." Some years after the riot, John, a son of the unfortunate pompeius, was in farour at Court, and married into the Imperial family:"

By the fortuitous suppression of the Nika revolt the despotism of Justinian was established on a foundation unassailable by any popular commotion. A few thousands of barbarian mercenaries maintained in the heart of New Rome had sufficed to coerce the democracy in the capital, and to stifle the indignation of the whole Empire against a shamcless and rapacious tyranny. Justinian's first care was to proclaim his victory orer the the usurpers and the rabble who supported them throughout the provinces," and then to restore the bureaucracy to its former efficiency for fiscal exaction. 'The ministers nominated under compulsion of

under an epitaph, "Here lies the kimperen of the Wolves" (see Ducange

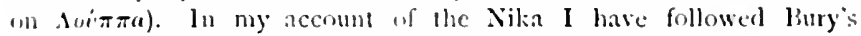
chromingy; fourn, of llellen. Sruelies, 1897. The sources are sometimes in clirect comflict, and have lo le econciled hy collating them attentisely.

III. Malala, wiii, p. 438 .

- I'rucupiun, le licl. Cinlle, iii. 31.

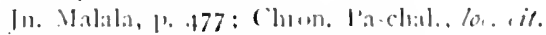

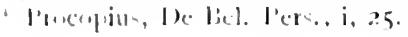




\section{Internal Administration of the Empire $47 \mathrm{I}$}

the vulgar outcry were soon displaced, and Tribonian and John returned to their seats at the heads of their respective departments, where they reverted to their old methods of statecraft and extortion.' The infamous Cappadocian resumed his sway over the Emperor and the Empire, and during the next decade almost all public Acts were headed with the superscription, "To John, the Most Glorious Praefect of the Sacred Praetorium of the Orient, ex-Consul and Patrician.".

'Theodora, on her side, to express her sense of assured supremacy, made a triumphal progress through the country to the hot-baths of Pythia," in Bithynia. A crowd of patr1cians, illustrious officials, eumuchs, and officers of rank attended her, constituting a retinue amounting in all to over four thousand persons. At every halting place she made munificent donations to the public institutions of the vicinity; and churches, monasteries, and hospitals benefited largely by her ostentatious liberality.

We should certainly do Justinian less than justice if we asserted that his regard for the welfare of his subjects was limited to a desire that no one should plunder them but himself. That statement, howerer, might not be an unfair definition of his objective attitude towards them. Three years after the rebellion he hegan the issue of a series of enactments intended to work a complete administrative reform throughout the Empire. He had in the meantime

1 Tribonian oscillated between various posts. Now he came hack as Master of the Offices (Cod., I, xvii, 2), but in 535 we again find him as Ounestor; Nov. xrii. In 545 he appears as Prnefect of the City; Edict ix (heading queried).

- Nor., ete., passim.

Procopius, De Aedif., v, 3 .

1 Theophane; an. 6,025, hut Malala puts it in $52 S(p .441)$. 


\section{The Age of Justinian and Theodora}

waged a successful war in the West, and for the moment the treasury was redundant with the rich spoils. His scheme of reform was doubtless influenced by this fact, and he legislated in the temporary belief that for the future the national burdens might be lightened.' His measures were direrted to three principal repuirements, vi\%, (1) to fortify the authority of his local viegerents: (2) to elevate their cthical motives by abolishing renality: and (3) to invigorate the collection of the taxes.

I. In order to achieve the first of these objects he began to reverse, in great part, the provincial policy elaborated hy biocletian and Constantine." In a number of provinces he dispensed with the dual control, and united both civil and military power in the hands of the Rector." Enlianced rank naturally followed this increase of authority, and thus the former Clarissimus rose to be a Spectabilis, whilst, at the -ame time, he was granted the emoluments of hoth offices.' I loftice official title was also necessitated by these changes, and hence a simple Praeses or Judex became a Moderator, l'raetor, or Count, and in three instances was elevated to the almost regal dignity of a Proconsul.' In some of these

1 He was in a very exalted frame of mind al lhis lime. c.s., "We

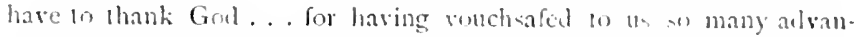
lages and so greal, beyond what Jle ever granted lo mur predecessors" ; Nos. s.riii, \& ; cf. Cod., I, xvii, 2, elc.

2 sec 1', 132 .

the give as his wanom that the military toukes and the civil

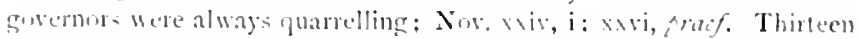
buke are named in the Notita, lut unter this change nine kectors

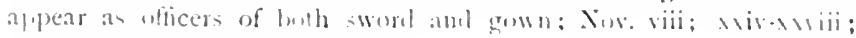

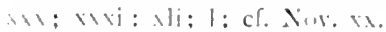

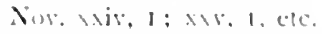

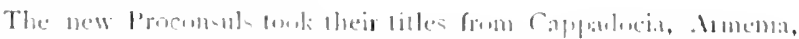

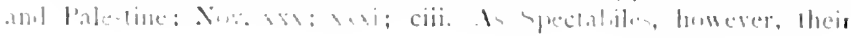




\section{Internal Administration of the Empire 473}

cases, however, the promotion of the Rector was due chiefly to the extension of his authority over a wider area. Some of the smaller provinces lying adjacent were annexed to each other, and received a single governor, especially those which had been previously known as "First "and "Second" of the same name.' In general the power of those Rectors who did not take over the military command was augnented by granting them an official guard sufficient to render them incontestably superior to such of the local magnates as had previously terrorized the district by the multitude of their armed retainers. ${ }^{2}$ As the ordinary judge, the Rector's posi-

precedence was only nominal, the Practors, ete, being also of that srade.

${ }^{1}$ Cappadocia I, II ; Nor. xxx. Patlestine I, II ; Nor. ciii. Libya I; II ; Edict xiii, 19, 22, etc. Helenopontus to Pontus Polemoniacus, Nov, xxviii. (Here we get some geographical information as to the limits of the Empire on the N.E. J. remarks that lityus and Sebasto. polis are rather military outposts than towns proper.) l'aphlagonia to Honorias: Nov, xix. A peculiar enactment, apparently without precedent, was the creation of a "Praefect of the Islands" with civil and military command over five scaltered provinces of both continents, viz., Scythia, Mysia, Caria, the Cyclades, and Cyprus; Nov. xli; l; see the remarks of $\mathrm{Jn}$. Lydus on this appointment; of cit., ii, 28 . There secms also to have been a junction of Dardania and part of Macedonia; Nor. xi; cxxxi. For all we know the provinces may have been dealt with seriatim from first to last. Numberless Acts have been lust, ats exemplified by the rescript of Anastasius discovered in the Cyrenaica, $1 \$ 27$, and that of Justin and Justinian in Pisidia, 1859, the former annotated by Zachariä (Sitz-Ber. d. Berlin. Akad., $1 S 79,1$, Ijt), and the latter by Diehl (École d'Ath., Bull. de Corr. IIel., I893, p. 50 I. It will be perceived that in these new arrangements there is something of a return to the regional dispositions of the early Empire; and, in fact, Justinian expresses himself in that sense more than once in these Acts (see p. I32).

2 Paphlagonia; Nov, xxix. Arabia; Nov. cii. Talestine; Nuv ciii. Later Arabia was renamed Palestine III ; Procopins, De Aedif., v, S. 


\section{The Age of Justinian and Theodora}

tion was also improved by opening his tribmal to lawsuits in which greater pecuniary interests were at stake.' Some control was also conferred on them over agents of the fiscs, whom they were enjoined to restrain from collection of funds for public works, unless they presented an imperial commission for doing so." Justinian further directed his vicegerents as to the official pageantry by which they were properly distinguished, and urged them not to lee lax in the mater of public display. They were reminded of their right to wear a purple robe of a certain form and hue, to sit in a silver chariot and to be preceded in their progresses by an officer bearing the axe and fasees." The Emperor himself was, indeed, unusually prone to ostentation, and when instituting these reforms he showed no little pride by enacting that all the newly created dignities should be denoted by the epithet "Justinian."

Another sweeping chinge made by Justinian at this time increased the importance of the individual Rectors by limiting their subservience to intermediary atuthorities, and placing them in more direct dependence on the bureatucracy of the cappital. He abolished the division of the Empire into dioceses, and the six groups of provinces which had hitherto obeyed an administrator in chief ceased to be regarded officially as being thus connected. The litle of Vicar became olsolete, and the four vicegerents who had borne it were resolved into simple Rectors of their residen-

500 solidi (f280) wa mow the usual manimum: Nox. axis, 5, ele. But the proconsul of takestine couth recite as high as 1011 . of 然小 $(200) ;$ Nor. ciii, I.

- Nov. xair, $3 ; \times x r$, f, elc.

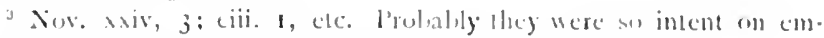
bezalement that they tial not trouble alwoul the esternals of office.

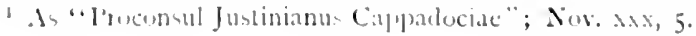




\section{Internal Administration of the Empire 475}

tial provinces.' The magnificent Count of the East was detached from his great array of provinces, and restricted to the governorship of Syria," still an enviable charge, since he reckoned Antioch as his capital; and the Augustal Praefect resigned the control of all Egypt for that of Alexandria and the adjacent country. ${ }^{3}$

2. The foregoing reconstruction was neither difficult to conceive nor inapplicable in practice, but when Justinian determined to quell the greed for illicit gains among his subordinates he struck at the most vital part of Byzantine officialism. With no halting judgement he began by directing the lethal weapon against his own breast, and decreed that in future no candidate should be permitted to secure an appointment as Rector by purchasing the interest of any of his great officers of state or their dependents. ${ }^{ \pm}$Henceforward the Rector, having won his commission simply by proving his fitness for office, would proceed to his government unhampered by debt, and no longer compelled to despoil the tributaries in order to liquidate his heavy obligations. With paternal benignancy he would mete out strict justice, and administer his charge with "pure hands," eschewing sordid gains, and content with the stipend allotted to him by the state. ${ }^{\circ}$ He would show no mercy to

I The Vicar of Asia became Count of Phrygia Pacatiana; V. of Pontus, Count of Galatia I; Nov. viii, 2, 3; V. of Thrace, Praetor of Thrace; Nov. xxvi. The Vicar of Macedonia is not accounted for; perlaps his office was in abeyance owing to barbarian inroads.

\footnotetext{
2 Nov, viii, 5 .

${ }^{3}$ Edict xiii, prate. $t$ t seq.
}

Now, viii, praef., I7.

"Ibid.; Nov. xxiv, I; xxy, 2, etc. I Iis favourite and frequent expression.

${ }^{6}$ Nov. viii, 8 ; xvii, 5 ; $x x v, 2$, etc. The salaries allotted seem to be very small, e.g., Praetor of Pisidia, sol. 300 ( $1 \mathrm{I} 65)$, Count of 
homicicles, adulterers, or abductors of virgins; would sternly suppress brigandage, and never cuail before the most potent and wealthy delinquent in his province.' Titles affixed to a neighbour's land, when found, were forthwith to be detracted and broken over the head of the offender, whether agent or principal. ${ }^{2}$ before his departure from the calpital he was obliged to attest his allegiance to the Emperor and Empress by a solemn oath, swearing at the same time that he had not obtained his post by bribery, and that his conduct should be in every way exemplary towards the suljects committed to his care." On arriving at his seat of govermment he was enjoined to convene the clergy and laity, and read to them the Imperial ordinances under which he had accepted office, a copy of the sime to be posted also in every district under his jurisdiction.'

Justinian did not, howerer, confine himself to exhortation and rerbal obligations to ensure the observance of his precepts, but he also had recourse to matcrial precautions against the Rector's deviating from the path of rectitude. In the first place local supervision of his actions was provided for in three different quarters. Primarily the bishops were authorized to receive complaints against the Rector, and even to lest their validity by sitting on the bench with him to hear causes in which his ruling had been impugned." I manclate was also addressed to the I)efenders of the

Isaturia, wh. $200(f, 15)$, but the Menlerator of lelenepontus gets s). $725(L+10)$, the Proconsul of (appadocia, $20 \mathrm{lb}$. of goll $(f S \infty)$, and for l'ale-tine, the same.

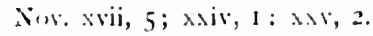

- Non. xxviii, 5 ; xxix, 4 ; sx., 8 , ctc. Less of the hamds might also be inflicted.

${ }^{3}$ Now. viii, 7, Jusjur. $\quad$ Nov. xvii, 16.

Nov. viii, Eil. ; Maxvi, 2, 3, 4; cf. cxaviii, 16, 17, ete. 


\section{Internal Administration of the Empire 477}

Cities, whose office hack fallen into disrepute, reviving and extending their powers and animating their energies. ${ }^{2}$ The Rector was deprived of the right of dismissing them from their posts, and they were directed to report him at headquarters if he presumed to interfere with their functions. ${ }^{2}$ Lastly the Emperor gave full force to the old injunction of Zeno that a retiring governor should remain for fifty days within his province, exposing himself to the accusations of all who should deem themselves aggrieved by his improbity."

Nor did Justinian dispense with a system of rewards and punishments to encourage the upright, or to deter the faithless Rector. Having won golden opinions from his official superiors, the former should expect to retain his position for a longer period and subsequently to be promoted to a higher charge with authority over a greater population." On the other hand, confiscation and exile, stripes and torture, were to be inflicted on the transgressor as the penalty of his misdeeds. ${ }^{5}$

Still further to safeguard the welfare of his subjects the Emperor enacted comprehensive measures to facilitate the administration of justice. In the provinces the legal status of the Defenders of the Cities was raised, and the inhabitants were directed to bring all minor cases before them instead of crowding to the Rector's court from the outlying districts. $^{\circ}$ At the same time courts of appeal were multiplied

Nov. $x v$. 2 Ilid., I, 5, etc.

Nov. viii, 9 ; xcv; cxxviii, 23 ; see p. 202.

Nov. xxviii, 7 ; xxx, Io.

${ }^{5}$ Nov. viii, $7 ; \mathrm{xxx}, 9$. The Defenders of the Cities are similarly cautioned; Nor. viii, 7, Edict I.

${ }^{6}$ Nov. xv, 3, 6; lxxxvi, 7. The limit of his court was 300 sulidi (£165). Generally the Bishops also had judicial functions, and like the rest are threatened, as not being always above suspicion; 1bid., 6. The

II. 


\section{${ }_{4} 8$ The Age of Justinian and Thiodora}

hy conferring on the Spectabiles intermediate jurisdiction between the Rectors of lesser rank, the Clarissimi, and the illustrious functionaries of the capital.' 'Thus the overwhelming influx of the provincials into the Imperial city, to lay their grievances hefore the supreme courts, was materially diminished. Similarly at Constantinople the activity of the puisne judges was much increased, and they were required to sit in the Royal basilica "morning, noon, and crening" to determine lawsuits of lesser import." A permanent Quaesitor was also appointed to deal specially with the throng of immigrants, to ascestain the propricty of their appeals and direct them to the proper courts; or, should it appear that they had come on a futile errand, to relegate them back to their provinces with letters rommending them to the notice of the Rector.

IIith a view to the repression of crime and the moral depuration of the capital Justinian also took some active measures, in which Theodora co-operated with him as far as the feminine element was concerned. Under the title of "Praetor of the People" the office of Praefect of the Watch, formerly an important post in the Roman muni. cipality, was restored, and a posse of soldiers and firemen was placed at his disposition.' 'To this practor, who might

cierics were instructed to resont fo them in the first instance, and only: aftermard- to the civil judges if the question prosed to lie legond their legal acquirments: Nos. Ixsxiii ; of. lssis.

Nor. viii.

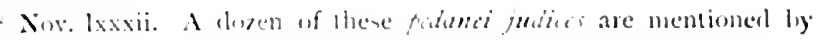
wame. In the capital they were mostly nolke, and of all ronks.

Nos. lass. If they were pused to be ille or unempluyed persons,

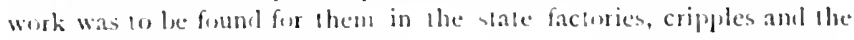
aged excepted; Itia., 6.

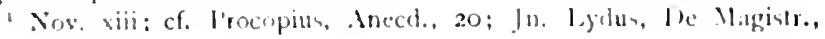


be a noble of illustrious rank, was assigned the duty of organizing a patrol of the streets day and night for the protection of life and property. At this time the traffic in prostitution had grown to enormous dimensions, and the country was overrun by panders who bought young maidens from poor parents for a small sum in order to devote them to public debauchery. Girls in their tenth year and upwards were enticed by promises of fine clothes and ornaments to become inmates of proprietary brothels, and were even paraded about the streets as decoys for the dissolute. The newly appointed praetors now received a mandate from the Emperor to suppress these vile habitations and to drive those who maintained them from the city.' 'The Empress herself had been for some time engaged in the work of reclaiming these unfortunates, whom she redeemed from their owners by paying a stipulated price in each case. ${ }^{2} \mathrm{~A}$ disused palace on the Bosphorus was converted into a Magdalen asylum, which she called "the Penitentiary"; and here a considerable number of former courtesans were immured in the hope of their moral reformation. Some scandal, however, was occasioned by the conduct of several of those rescued, who, driven to despair by the monotony of their new life, preferred to throw themselves from the windows at night into the water to enduring the unaccustomed restraint; but we may assume the comparative rarity of this untoward result." Justinian also pronounced

ii, 3o. Twenty soldiers and thirty matricarii (firemen?) were allotted to him. As we have seen (p. $\left.S_{1}\right)$, there was from the first a regional band of the kind; but perhaps this new body was general and supervisional.

1 Nov. xiv.

2 Jn. Malala, xviii, p. 40; "five pieces of money," not aurei, but apparently coins of small value.

3 Procopius, Anecd., I7; De Aedif., I, 9. 


\section{tho The Age of Justinian and Thoodorer}

rery stemly against paederasty, and even made a public example of certain hishops who were convicted of that offence.' He further forbarle the making of eunuchs within the Empire, threatening confiscation, exile, and retaliative castration against those who infringed his prohibition." Consistently he ordained that emuchs of servile condition should for the reason alone of their defect become free men."

3. In the midst of his most carnest efforts at reform fustinian never failed to impress on all concerned that with himself and his Imperial partner the rights of the crown and the maintenance of the revenue were of paramount importance." At the head of their codicils the Rectors were admonished to make it their study above all things to expedite the fiscal exactions: whilst the tributarjes were warned that no matter how vehemently their governor had (nforced payment of the imposts, no cause of action was sranted to them against him. On the contrary, they were to conduct him with all deference from the province at the end of his term, and, should they presume to molest him during his fifty days of postponed departure on that account, they would be subjected to penalties of exceptional severity." The Emperor deplores the diminution of Roman territory

Nur. lnxvii; cxli; l'rocopius, Aneal., 16, 20, etc. They were sulijected to amputation of the offending member and exhilited pullicly in their mutilater condition; In. Malal:a, p. 430. Isaiah of khodes and Alexander of Dinpulis are mentioned as Bishops thu, treated. "II leur tit couper les reins, qu'il fit exposer à un proteau. . . . Un héraut criait," etc. Michacl Melit. (Langloi-), p. 193. J. was remonstrated with on the cruedy of the procerlure, whereupon he replien, "If they hal commintel acrilege, would you not have cul off their hamb?" Zonaras, siv, 7 .

- Nor. calii.

Iliil.

Nor, xuviii, .7; sxix, $5 ; x \times x, 6,11$.

Nov. viii, 8, 10; xxviii, 5 .

'Nov. viii, 10. 


\section{Internal Administration of the Empire $48 \mathrm{I}$}

which has resulted from the inactivity of former rulers, and calls attention to bis own energy and prowess by which the repair of their errors has been begun." Military operations, however, are expensive, and hostile incursions can only bc repelled if people respond freely to the demands of the tax collectors. $^{2}$ Justinian asserts that he disdains to imitate the example of his predecessors who sold the offices of the state, thus depriving themselves of the right to expostulate with unjust administrators who embezzled the national funds." But a new era has now dawned, government with pure hands is assured for the future, and liability will be limited strictly to the legitimate imposts. Therefore let all alike sing hymns of praise to God and the Saviour for the passing of these new laws.

Justinian, notwithstanding his professions, was mainly influenced by the hope of pecuniary gain when he essayed to reverse the administrative system of his predecessors. He calculated that the rooted abuses which they had tolerated for centuries were a cause that only one third, possibly, indeed, not more than a fourth, of the tases collected found their way to the Imperial treasury." Hence his

1 Nov., xxv, I I ; cf. Cod., I, xvii, 2, etc.

Ibill., I I.

Nov, viii, praef. This is his first great lieform Act, to which the rest are expletory. He opens by celebrating his public spirit and philanthropy. "Day and night alike we devote to lucubrations and cogitations respecting whatever may be of utility to our subjects, so that they may be able to live peacefully and free from all anxiety, "etc. But he soon begins to let the cal out of the bag-- "VVe find that many causes of injustice have crept in whereby our subjects are reduced to indigence, so that they cannot pay the proper tributes. . . Irotected from the oppression of the governors, they will thrive, and hence the state and treasury will oretflow, having rich taxpayers at its disposal," etc. 
ministry of the interior soon resolved itself into a mere organization for the invention of legislation which would conduce to the raising of money.' 'The devices which sugrested themselies from time to time as financial expedients were multifarious and of the most unrelated character. Some of these have been already alluded to," but a few others which were productive of more signal changes refuire particular notice. Roman Armenia was joined to the less important regrion of that name on the west of the Euphrates and reduced to the level of an ordinary province, with a Proconsul for its principal Rector." Consequently taxes were imposed, and the inhabitants found themselves racked for payments which they had previously escaped.' In the time of Justin. Justinian added four troops to the Scholars of the Palace, and recejved from each new member a premium for his position in the force. Soon after his accession he disbanded them as a measure of retrenchment, but retained the purchase money. Subsequently he made a practice of ordering these carpet soldiers for active service, with the understanding that they would buy themselves off the dreaded prospect by surrendering a quota of their pay. Every opportunity was taken to consolidate trade monopolies to the advantage of the government: and this was

1 Procopius, Anecl., fassim: In. Lydus, 1) Magistr., iii, 57-70; lonaras, xir, 6.

- Sice pp. 198, 444 it seip.

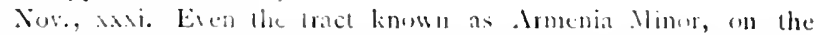
proximne hank of the river, which ban long been an inlegral part of

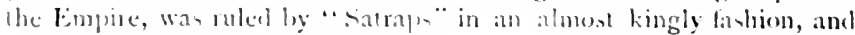
a semi-legal contume wan permitted whem. Font werc abolisher by \%enes an account of diatfection (I'rucopliue, De Aedif, iii, 1), and the

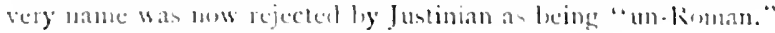

l'ucopiu, 1)e licl. l'er., ii, 3 .

l'rocopius, Ancel., 2.4.

"lliti, , 20. 
especially the case with respect to silk. Justinian pretended to be indignant when a rise of price was operated by the deficient supply, and decreed that the maximum retail cost should be eight solidi ( $\mathcal{L}_{+}$Ios.) the pound. ${ }^{1}$ Confiscation was the penalty for contravening this regulation, but the traffic was still carried on in secret. Here Theodora found an opening for the exercise of her talents, and through private channels succeeded in discovering the merchants who were implicated. Thereupon a fine of $100 \mathrm{lb}$. of gold $\left(E_{4}, \infty 00\right)$ was imposed on each of them. ${ }^{2}$ Soon the factories at Tyre and Berytus, the headquarters of the commerce, began to languish, the operatives were thrown out of work, and ultimately the Praetorian Praefect possessed himself of the whole manufacture. Exorbitant prices were then fixed which yielded an immense profit to the Imperial exchequer, but numberless persons were ruined during the process of transfer. $^{3}$ Like results obtained in relation to the corn supply of Egypt through manceuvres at Alexandria, by which the Praefect of the City was constituted the sole purveyor of that commodity. A scarceness and dearness of bread was the natural consequence of this innovation." Another fiscal move, far-reaching in its effects, was the diversion of the separate revenues of the municipalities ${ }^{5}$

1 l'rocupius, Anecd., 25.

$=$ Itiit.

${ }^{3}$ 16id. The rise in price was so great (nearly forty to one) as to be almost incomprehensible, but the manuscript was corrupt, and has been emended on conjecture by Alemannus. It appears, however, that the value of ordinary silk returned to what it was under Aurelian (see p. I33, its weight in gold), while the Imperial purple (holovera; cf. Corl. Theod., X, xxi; Cod., XI, is) was rated at four times that amount.

${ }^{1}$ Procopius, Anecd., 26. The panis gradilis (see p. SI) was now abolished at Alexandria.

${ }^{5}$ See p. 147. 


\section{fit The tge of Justinian and Thodora}

inte the hands of the Emperor. The local curiac being no longer permitted to deal with them, public works were neglected and the inbabitants ceased to be entertained by the popular specticles.' $A$ blight secmed to fall on the Empire, says the contemporary historian, and people had no resource but the discussion of present calamities and the expression of their fears for the future." Related to this policy was the formal abolition of the Consulship with its attendant train of festivities which enlivened the opening of each year. During the space of a decade the office hat only been filled in a desultory manner, but the last Consul wis actually seen in 54, and soon afterwards that link between the Byzantines and the glories of the old Republic was severed by a definite. Ict. 'To tamper with the currency has always been an inviting procedure with needy princes, and Justinian did not resist having recourse to this artifice. by giving a fictitious value to copper he managed to rake in the goll coinage at about five-sixths of its actual worth.' such are the chief methods by which in this reign the revenue was inflated beyond its normal proportions, and, to complete the list, reference may be made to ill-advised

Irrocopius, Inecl., 26.

- Ibill.

thit. The leat of the decree has not come down to us, but lasiliue was the last Consul, and subsequently official ducuments are dated an "An. I, II, elc., fort biasil." Vel only hive years before Jutinian drew "l], elatorate rules for the observance of the consular

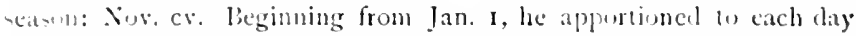
of the reck its quantum of processions with scattered largess, horse races, hum with dogs in the amphitheatre, boxing and wertling, man and beast fights, and theatrical tisplays in which the foove feminine element preduminated.

"l'recepiu, Anect., 25. He emacted that mly iso pence (fellis,

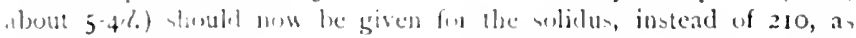
formerly. See pe 122. 
economies effected by the suppression of pay and pensiuns usually granted by a state and to forfeitures of private property constantly decreed on slight pretexts. ${ }^{2}$

If Justinian's studied scheme of reform could have been applied successfully in practice, it is possible that fiscal oppression might have been banished from the Empire. But the Autocrator at Constantinople was scarcely more than a suzerain in the provinces, and his fiat was but slightly regarded by those who occupied any position of power in dis tricts remote from the capital. ${ }^{2}$ Doubtless his technical enactments as to the rank and territorial jurisdiction of diverse Rectors were received as indisputable, but at the same time they marked the limits of his power to work a change in methods of local rule which had been practised for centuries. Once invested with authority, the provincial governor departed to tread in the footsteps of his prede-

"Procopius, Anecd., 19-22. A particular impost called the "aerilion" (windfall) worked by the I'raetorian Praefect, produced 3,000 pounds of gold $\left(f_{12} 20,000\right)$ annually. It seems to have been an income tax levied on governmental employees. Itid., 2[. The epibole (waste land tax; sec p. I51; Cod. Theod., XIII, xi, I2; Cod., XI, Iviii; Nov. clxv, ctc.) was pushed to the most oppressive extreme in this reign. Ihid., 23 . One special instance of the subterfuges resorted to for confiscating private property may be cited. A lacly of Ascalon, married, inherited cunsiderable wealth from her father, and subsequently as a widow, by the death of her only child, became heiress of her husband's property. Forthwith Justinian seized on the whole estate, declaring it iniquitous that the old lady, as she had now become, should be enriched by both father and husband. Ile, however, granted her a pension of one solidus a day, explaining that he did so "for the sake of piety, and because it is my custom to act in a holy and pious manner." Ibid., 29. Other examples in same chapter.

"Speaking of Egypt, he remarks tilat "matters have been so confounded down there that what is enacted in the province cannot be known here [CP.]"; Edict xiii, praef. 


\section{fis6 Thi Ase of / ustimian and Theodora}

cessurs, while the same futile prohibitions continted to isste periodically from the mouth of the Emperor, secluded in his distant court. before the lapse of a twelvemonth Justinian resigned himnelf to ignoring his own self denying ordinance, and a candidate for office was noted only in relation to his ability to pay at the moment, and the mannitude of his promises for the luture." His repeated denunciations of the venality of his vicegerents represented no more that his formal recondition of the lamentations which continnally reisched his trihunal, or his exasperation at a prospective loss uf revenuc from the flagrant excesses of some rectiless extortimer. He was also extremely parsimonious in remitting

In 54 she recetablishal the Vicar of lentur on account of the ineralicalle disurlers. Iti, jurieliction incluted all the nuthen

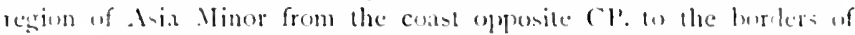
Armenis. Iliv lask $\mathrm{i}$, as ustal, ar restrain every sont of oulrage on whmen and property, the culprit, being men of all ranks, "picats,

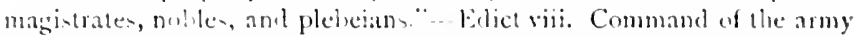
in given him for the purpose. In 545 , and exen twenty year later, the injunction a. Lo the fifly day' delaty is still being launcleet at the Rectors: Nox. caviii, 23; chi, r. In 556 an all-romel diatribe denomees the lime-homoured malpractices of local rulers, the bishops even being incluter in the protibitions: Nisy. exasir. Imperial decreen were senerally acompraied ly a theat that a line of 10 pound of gold

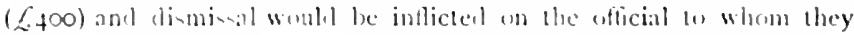

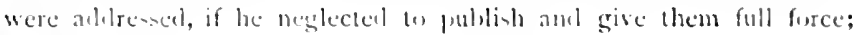
Now. s, etc.

- I'ruciplus, inecel. 21 .

That funtinian and hi comwert were hele in general delestation

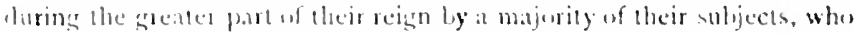

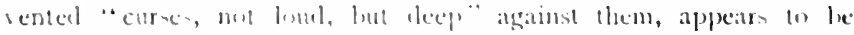
indicaleal clearly ly the expensem of l'rocopius. "Wherefore I, and

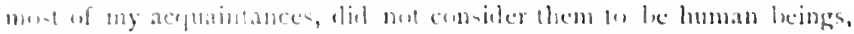

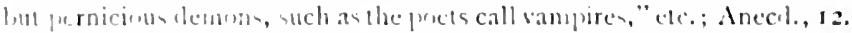

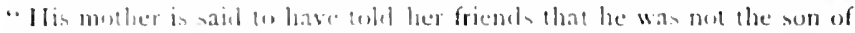
Sablatim, mer of ans man, but that before her pregnancy a species of 
arrears of taxation, even in districts which had suffered from hostile invasions or other calamities. Thus numbers of the small landowners were allowed to languish under the apprehension that at any moment their whole property might be seized in order to wipe out their liabilities. ${ }^{1}$

$\Lambda$ river of wealth flowed through the Byzantine exchequer at the bidding of the Emperor. The sources were exhausted, and the reservoir was discharged under the influence of the same will. The people, who formed the well-head, suffered untold miseries in contributing under compulsion to the supply, but they possessed no control over the ultimate distribution of the stream. These activities have now been sufficiently considered on the one side; it remains for us to turn our attention to the other. During the twenty years which followed the Nika rebellion the reign of Justinian was distinguished by a series of magnificent achievements both at home and abroad; great works were accomplished within

demon came to her "; loid. "That he was not a man, but a demon in human form, any one could prove ly the magnitude of the ills which he brought on the human race "; Ibid., IS. Jn. Lydus, however, always represents Justinian as being "good and kind," "long-suffering," etc., and as quite ignorant of the doings of John, who bullied his subordinates so that none of them would have dared to breathe a word against him; De Magistr., iii, 57, 69, etc. Lydus was a clerk in the civil service, who rose to be the head of a department, but he complains that he never received his pay; $16 i d ., 66,67$, etc.

1 Procopius, Anecd., 23. He made no concessions whatever, according to our author, writing in 550 . Ifis first, and apparently his only, remission of arrears was, in fact, not made till 553; Nov. cxlvii. Malala (p. 437) records that in 528 he abolished some tax, a subsidy to the Gothic foederati. The defaulting tax-payer was put on a level with the honicide, and denied the right of sanctuary in a church; Nov. xvii, 7 . To the Rectors he says, "You must see that exaction of the public tributes be decently effected, even in the Temples . . . the ecclesiastics will aid you," etc. 


\section{tSi Thi. Ise of Justiman and Thoodora}

the Empire: beyond its borders aggressive wars were waged and a moiety of the Mestern Empire was restored to the dominion of the East. But the background of this brilliant scenc was always of the same gloomy tint, such as has been described in the present chapter, and these splendid successes were obtanined at the cost, but not to the advantage of the (ireck mation in general. While Justinian went on adding magniloquent epithets to his name indicative of conquest and triumph over alien races in the West,' his immediate subjects continued to be afflicted by the harshness and rapacity of the administration, as well as by the tyranny of the local aristocracy. Concomitantly the barbarians in Europe and the Persians in Isia sapped the vitals of the Empire and impoverished or enslaved its inluabitants. Victory and acquisition abroad by the aid of mercenary troops were nullified by defeat and exhaustion at home; and the extended Empire which Justinian handed down to his successors was inferior in political vigour and sociological prosperity to the smaller dominions which he had inherited from Anastasius.

' His fulle- style i,: "Imperalur Caesar Flasius Justinianus, Ncmannicu, Guthicus, Francicus Germanicus, Lacicus, Alanicus, Vandalicu, Africanus, pius, felis, gloriosus, victor ac trimmphator, nunquim uon colendu; . Iuguslus "; Nov, sliii ; cl. Chron. l'aschal., an. 552 , elc. If he comld have added "Persicus" in the beginniug of his reign, it wull have leen worth all the rest. 


\section{CHAPTER VIII}

CARTHAGE UNDER THE ROMANS: RECOVERV OF

AFRICA FROII THE VANDALS

THE Vandalie settlement of Afriea (in Imperial nomenI clature the name was officially reserved to the northwest portion of that continent) was more keenly resented by the Romans than the barbaric oecupation of any other province of the Western Empire. In other instances disintegration had been gradual and the territory had becn resigned to the new possessors with a sense of political inability to retain them, whilst a semblance of fealty to the Eastern Emperor indulged his pretensions to supremacy; but Africa had been snatched away by a sudden conquest, and became a hostile eentre from which depredations against the opposite shores of Europe were for long the avowed object of its ruler.

Subsequent kings of the Vandals found the means to cement an alliance with the Empire, and Justinian himself was in amicable relationship with the contemporary member of the dynasty. Internal dissensions, however, had recently effected the abrupt overthrow of his ally and the Emperor vainly intervened on his behalf. A rupture of diplomatic relations followed, smouldering enmities were rekindled, and the question of despatching a military force for the recon- 


\section{The Age of Justimian and Theodora}

quest of . Ifrica was seriously mooted at Constantinople. Justinian felt strongly impelled to the exceution of the project, and brought the subject up for discussion in his Consistorium. There his proposals were received with tacit disfavour, the remembrance of a former expedition, which had ended in disaster, weighed on the minds of the nobles in attendanec, and the army contemplated with dread the idea of a campaign of which a long scal royage and naval warfare seemed to constitute the essential features, whilst the Counts of the Treasury trembled at the prospect of an expenditure which their funds might be inadequate to meet. But none dared to appear in open conflict with the manifest wishes of the Emperor, until at length John of Cappadocia rose and delivered a definitely adverse opinion. Interlarding his discourse with much that was deferential to Justinian and laudatory of his political capacity in general, he urged with bold logic the most obvious objections. The journey would occupy more than four months, wherefore news as to the progress of the war could not reach the capital in less than a year after the start. Should the ammuncement of victory at last break the suspense, it must at once be felt that the distant province could not be held in permanent subjection owing to Italy and Sicily being under forcign domination. On the other hand, should ill success attend the operations, the enmity of a powerful lingelom would hate been provoked, and the limits of the Empire would have to be defended against hostile reprisals.'

Justinian assented to these argmments, and for the time smothered his rescontul ambition to punish the offending power, font after no long delay the question was finally 
determined by a point of religion. The Vandals were odious in the eyes of the ecclesiastics of the East, Arian heretics who had gained the upper hand over an orthodox Christian population; and a fanatical bishop, indignant at the failure of the deliberations, hurried from his see in Asia Minor to the Imperial Court. There he represented to the Emperor that in a divine vision he had been ordered to reprimand him for being deterred by vain fears from his righteous purpose of upholding the Church. God had spoken to him in definite language, and said, "Tell the Emperor that I will be with him and will reduce Africa under his dominion." Justinian was convinced immutabiy, and made all haste with his preparations so that the expedition might be ready to start in the proximate summer $(533) .^{1}$

The country which Justinian was now about to invade, a vast and fertile region sufficiently spacious to form a separate empire, has always within the historic period been the seat of a prosperous, though fluctuating civilization, yet never of indigenous growth. Successively Phoenician, Roman, Vandal, Byzantine, Mohammedan, and French, during the long tract of three thousand years, the numerous native population has invariably been a subsidiary and more or less disorderly element of the political entity. ${ }^{2}$ At one of the most picturesque moments of antiquity we are presented with the scene of Caius Marius sitting as an exile amid the ruins of Carthage. ${ }^{3}$ That incident occurred more than half a century after the destruction of the city ( 146 B.c.) owing to the sub-

${ }^{1}$ Procopius, De Bel. Vand., i, Io. The only authority for the Vandal war is Procopius, whom later chroniclers abridge and generally refer back to.

${ }^{2}$ See recent French works on Algeria by Vignon, Wahl, etc.

${ }^{3}$ Plutarch, Marius. 


\section{2

jugating anmosity of Rome, but about thirty years previously at deeree for the colonization of the deserted site had passed the semate, and une of the (iracehi had actually conducted a party of six thousand sutters to rebuitd and re-people the l'unic capital. Official sanction, however, was shortly withdrawn from the enterprise owing to a recrudescence of superstition, or rather, perhaps, to a shift of political power, and for nearly a century the district was abandoned to decay before an earnest effort was made to restore it to afluence and oreler. The actual rebuilding of Carthage was due to the initiative of Julius Ciresar and the action of Augustus; and the resuscitated city rose to importance so rapidly that in the time of the elder Sercrus it was regarded as second (n)ly to Rome. A Proconsul, the only deputy of that rank in the Western Fmpire, governed the province in which it wits situated, and was held to be at magistrate of superior consequence to the Vicar of Africa, under whom five lesser governors controlled the country, 'with the exception of the "restermmont district, which was in administrative conjunction with Spain. The seren provinces of Africa thus constituted extersted for tifteen bundred miles in a straight line aloms the hasin of the Mediterrancan and included the modern divisions of Morocco, Ilgiers, Tumis, and 'Tripoli. South.

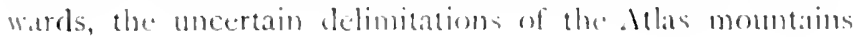

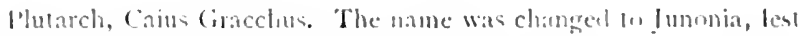

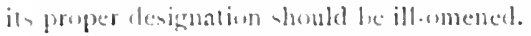

Appian, llis. Kom, viii, 136; Lillinun, 27, elc.

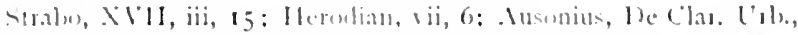

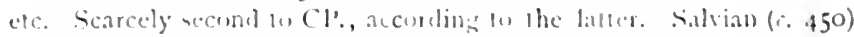

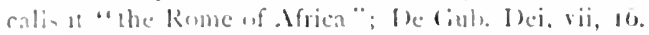

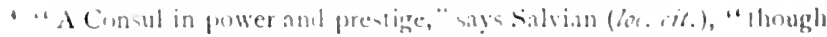
unly a l'ro in name."

Notinin Occiu. 


\section{Carthage under the Romans}

and the Libyan desert allowed the Romanized region a breadth which varied from fifty to two hundred miles.'

Carthage was situated on the shore of a small bay, and faced to the east, over against the Hermaean promontory, ${ }^{2}$ looking towards Sicily from a distance of one hundred and twenty-five miles. Being essentially a maritime capital it was distinguished by the extent of the accommodation it offered to shipping; and for more than a mile along its seaward aspect was bounded by a line of quays protected by a series of breakwaters from the violence of the waves. ${ }^{3}$ On the south an inner harbour, called the Mandracium, artificially constructed, was entered by a narrow channel defended by the usual device of a chain.' Still lower down a natural expanse of water, land-locked and of considerable area, known as the Stagnum, was capable of receiving a vast congregation of ressels. ${ }^{5}$ The Nandracium was circular in form, and contained in its centre a small island of the same shape. The annular channel thus formed was bordered all round on both sides by colonnades which extended into the water. A

'Named consecutively from east to west the seven provinces were Tripolis, Byzacium, Zeugitana ("Proconsular Africa," cap. Carthage; now Tunisia), Mauritania Sitifensis, M. Caesariensis (these two constitute the modern Algeria), and Tingitana (now Morocco). All lay along the irregular coast.

"Cape Bon (Ras Arldar).

${ }^{3}$ The remains of these works are still to be seen under water. Thcy were so considerable in Bruce's time that he fancied most of Carthage must have been submerged; Travels, etc., I790, i, p. xxi. The best compendious guide to the existing ruins of Carthage is Babelon's Carthare, l'aris, I 896 . He was one of the excavators, and gives a large map which indicates everything remaining on the site.

${ }^{4}$ Procopius, De Bel. Vand., i, 2o, etc.

' Ibic., 15, etc. Now the Lake or Lagoon of Tunis. Carthage was at the north-west corner, Tunis diagonally at the opposite one. About two miles long, one and a half wide.

II. K K 
double ring of covered docks was thus constituted, the space hetween each pair of adjacent columns being adapted for giving shelter to a single ressel.' The palace of the l'raefect in charge of the navigating interests rose from an elevaled spot in the centre of the island, and was used as a post of observation from whence he could survey the activities of the port." linom the northern extremity of the line of quays a staimway of great width and proportions, bounded and divided hy ormamental balustrades, ascended by more than a hundred steps, and formed a grand approach to the city proper, which was built on ground somewhat raised above the sea level. A hroad marblepared terrace, from which the inhabitants could orerlook the qualy and the water, formed the marine limit of the city at this higher altitude.' It was called the New Plaza." Roman Carthage was adomed

1 See Appian's description of the l'unic harbours, the Cothon, etc.; viii, 96 . The entrance at this time was probably that artificially ex. carated ly the Carthaginians after Scipio had hocked that in previous use. The hurbus was most likely restored hy the Romans to very much it. former state. Kambaul has alopted this view in his archaeological restoration of Carthage (c. 690), which he pul into novelistic form; Limpereur de Cuthage, Paris, 1904. Dureau de la Malle argues from texts that carthage was not "rated to the groume," at the formal ex-

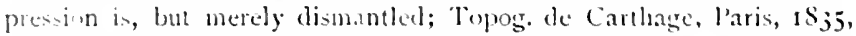
p. 10, , $a$ t $5 \%$. Certain ponds now in existence seem to tepresent the intand port, but an opposition view has been taken: C. Turr, Clansical lice, 1891 .

- The inlant apparenty in sill there, but no remain of buildings have heen uncuscred w far. For what has leen done see Babclon, of wit.

sume ruin sill temain and sutficiens of the structure to present an impoing atplearance exi-ted well inte the tase century. lieing quarried for later pumpere, the relic has grarlually lon it divtinctive form; see

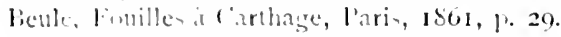

' Victer Vit. We l'creec. Vand., ii, 5 (written ${ }_{4} 457$, and proves the caistence of the stanway, eic, in the fifth century".

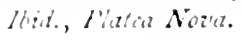


with all the usual components of a great capital in this age; a spacious forum lined with porticoes, ${ }^{1}$ colonnaded streets, and public buildings suited to the needs of the governing class. The litter occupied the citadel, a lofty mound centrally situated, the transformed Punic Byrsa. ${ }^{2}$ As special features the main thoroughfares were shaded by rows of trees, ${ }^{3}$ and a remarkable street was devoted solely to the trade of the money-changers and silversmiths.' Spacious halls for the accommodation of professors of the liberal arts and philosophers, ${ }^{5}$ churches, public baths, theatres, a hippodrome, ${ }^{6}$ and a substantially constructed aqueduct more than fifty miles long, ${ }^{7}$ completed the equipment of the African capital. 1 remmant of jealous apprehension, inherited by successive generations of Romans, decreed that Carthage should remain without walls, and only in the first quarter of the fifth century was the defect supplied by the younger Theodosius." Soon after the establishment of the Empire Africa became the granary of Italy, and, as later Constantinople was dependent on Alexandria, the arrival in the

'Appian, viii, 133 (from Diod. Sic., xi, 26).

"Inferred from Tacitus, IIist., iv, $3 S$, and Procopius, De Bel. Vand., i, 2o; see Dureau de la 入alle, of. cit.

${ }^{3}$ Expos. Tot. MIund. (MIiller).

Ibid. (two versions); Augustine, Confes., vi, 9.

5 Apuleits, Florid., is.

"Generally see Salvian, of. cil., vii, 16. The remains of the Circus are still in evidence; see liabelon, of. cit.

' Much of it still remains; figured in Babelon (op. cit.) and Davis's Carthage, etc., Lundon, 1868 , with other Roman ruins of the region. The populousness of Africa is indicated by the amphitheatre of Tipdrus (100 miles south of Carthage), capital of Byzacium, which still exists in great part. It was second only to the Coliseum.

- I'rosper Tiro, Chron. (424). Diocletian, however, carried out extensive works here, part of which may have been protective; Aurel. Victor, in Vita. 


\section{The Age of Justinian and Thiodora}

Tiber of the com fleets from Carthage was a matter of vital importance at Rome.'

The character of the Africans has been painted in the blackest colours by more than one writer of this age, and it appears to be indisputable that for the extremes of luxury, vice, and perlidy they were justly censured by their follow subjects. It was possible, we are told, that, owing to the populousness of the country, a few virtuous citizens might be found:" but the most obvious impression was that all without exeeption were addicted to drunkenness and immorality of the vilest form." The prostitution of both sexes had attained to a degree elsewhere unknown: and the streets of Carthage were thronged with males, who msexed themselves habitually by adopting the manners and costume of the opposite sex.' Ethnologically it is certain that the population was extremely mixed, and the semitic factor was well represented for many centuries after the Roman conquest." Hence the Latin language had not displaced the

1 Tacitu- Hist., is, $j$, ele. In the time of Vespasian it was fearcel that a revoll in Africa weuld lead to the cappital being starved out.

Ter. Orls. Descript. (Müller).

"Salvian (of. cill, rii, 13 ) is copions in hiv condemmation of the Africans and concedes llem no merit whatever. "The fiolls are per. firlinse, but continent; the dlani incontinent, but less pertidious: the

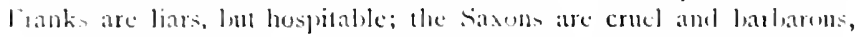
but wonderfully chante. In almose all Africans I kmun natught luu cril. If inhumanity i blamalle, they are inhuman; if drunkennes, they are

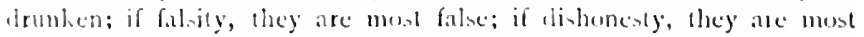
frawlulent; if avarice, they are most atracious: it perficly, they are most fermlious. but they are immoral leyond the measure of atl these latien legether." In hiv own. Aguitain the complatin is that the nulles have their houses full of madecrsants whom they use ats concubines.

' Mitil, 1;, 1S, 19.

When Mithradates atcempled to overthrow the koman poucr in the 


\section{Carthage under the Romans}

Punic tongue, even among the higher classes, as late as the reign of the Antonines. ${ }^{1}$ Again, the native races, known as the Moors, Kabyles, or Berbers, ${ }^{2}$ were more prone to live by war and rapine than to bow to the Roman sovereignty. On several occasions, therefore, the African provinces had been the scene of scrious revolts which had to be suppressed with all the force of the Imperial arms. ${ }^{3}$ Christianity spread rapidly among this heterogeneous and hot-blooded population and, as might have been anticipated, assumed a very

East (SS B.C.) they were considerable enough to send him an embassy proffering their aid; Athenaeus, v, 50.

1 Thus the son-in-law of Apuleius at the age of twenty could speak only Punic; Apology; cf. Procopins, De Bel. Vand., ii, Io. There were in Numidia, he says, two white columns on which was inscribed, "We are those who lled before the face of the robber, Joshua, the son of Nun." Some notion of the dress of the Carthaginians under the Empire may be formed from mosaics unearthed of late years and preserved in French museums. There was nothing very characteristic, but I may quote the following summary of what is to be seen. "Hommes en longue dalmatique rerte ou blanche once de larges bandes de broderies, avec le manteau triangulaire de laine brune enveloppant le buste, et l'orarium passé autour du cou; femmes en ćtroites robes collantes lrodées au con et au poignet, serrées ì la taille par un ceinture rouge et que recouvre une ample tunique aux larges manches de couleur échatante, avec les bijoux sur la poitrine, l'écharpe claire flottant sur les épaules et parfois encadrant le visage; enfants en culottes collantes alternées de jaune et de rouge, ou courtes tuniques blanches à bandes de couleur'"; Diehl, L'Afrique Byzant., Paris, IS96, P. 392. A mosaic found in Numidia shows a Roman mansion with horses, ete., and might pass for a riew of an English manor-louse; Tissot, Géog. Comp. d'Afrique Rom., Paris, I $884, \mathrm{p} \cdot 360$.

3 An exhaustive treatise has been deroted to the manners and customs of this people by Hanotaux and Letourneux, La Kabylée, 3 vols., Paris, IS92.

${ }^{3}$ One of the most important revolts was suppressed by Theodosius, father of the first emperor of that name; another by Stilicho, the famous general and father-in-law of Honorius; Claudian, De Bel. Gildonico. 


\section{${ }_{49}$ The Age of Justinian and Theodora}

contentious character. Thus the fiercest schismatics and sectarians who arose in the West, the Donatists and the Novatians, had their origin exclusively or mainly at Carthage.' $A$ fair proportion of the eminent men by whom the latin half of the Empire was distinguished were Africans by hirth and, perhaps, by blood. Imong the lagans we find the incomprable dramatist Terence, who flourished during the time of the Republic; the last of the great soldiers who ruled the Empire integrally before it began to succumb to the barbarians, the Emperor Septimius Severus: and the elegant writer Apuleius, whose apologue of Cupid and Psyche has secured a place in the litcrature of all modern languages. The Christian Ifricans also produced perhaps the most notable of the adrocates and authors who illustrated the early centuries of the Church; the vehement Tertullian, whose fieree style would lead us to suspert him of kinship with the restless autochthons of the land; the scarcely less ardent Cyprian, the masterful champion of episcopal vigour, who suffered martyrdom under Valerian: and the diligent Augustine, devout, mild, and imaginative, to whom the theology of the West owes its distinctive (haracter.

The romantic story of the loss of Africa, the veiled rivalry of Aetius and Bonifacius, and the treachery of the former, so fraught with evil to his country, is an oft-read tale to whic! a passing allusion will suffice for this page. The Count of Africa, being led to believe by his insiclious friend that the Empress Placiclia meditated his ruin, attempted to secure himself by inviting (ienseric, ${ }^{2}$ ling of the Vantlals

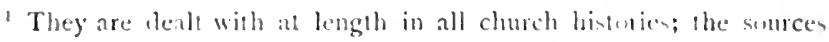

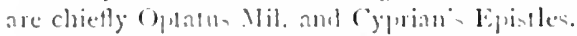

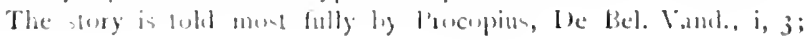


in Spain, to share with him the sovereignty of the seven provinces (429). Bonifacius discovered the deception, but too late to retrieve his error; the barbarian monarch harl made good his footing in the country, and the Roman general, having failed to arrest his progress in battle, was ultimately driven out of Africa. ${ }^{1}$ During ten years Genseric worked his way to the east, gradually possessing himself of the provinces, and in 439 crowned the success of his adrenture by the capture of Carthage. ${ }^{2} \quad A$ score of years later the Emperor Majorian fitted out an expedition for the expulsion of the Vandals; but the treason of his own officers brought about the destruction of his fleet in the bay of Carthagena, and the enterprise collapsed. ${ }^{3}$ A decade elapsed and Genseric was again threatened by the eastern Emperor Leo, who massed together ships and troops at an immense expenditure for the reconquest of Africa. Owing to the incapacity or, perhaps, the perfidy of the commander, Basiliscus, the brother-in law of the Emperor, this expedition also resulted in a disastrous failure.' During his long reign of nearly forty years Genseric was the terror of the Mediterranean, and in 455 , incited by another unpatriotic invitation, invaded Italy and sacked Rome at the instance of the ex-Empress Eudoxia. ${ }^{5}$

cf. Jorlanes, De Reb. Get., 33. Boniface was a friend of Augustine, who reproaches him for his conduct (Epist. 220). The name of the Vandal king is found variously as Genseric, Gizeric, and Gaiseric.

1 The sequel to the story seems to be historical. After his return the Count of Africa met Aetius in battle, but, though victorious with his troops, received a mortal wound from his rival's lance.

2 I'rocopius, loc, cit.; Marcellinus Com., Chron., an. 439, etc.

${ }^{3}$ Procopius, 20c. cit., 7.

+ Ibid., 6. He gives the cost of the expedition as 130,000 pounds of gold $(£ 5,200,000)$.

${ }^{5}$ Ibid., 4, 5; cf. Jordanes, op. cit., 45. She was the daughter of Theodosius II and widow of Valentinian III, her cousin. She was 


\section{The Age of Justinian and Theodora}

The orthodox Christians suffered much from the persecution of their Arian conquerors, ${ }^{1}$ but under the mild rule of Hilderic, who succeeded in 523, the peace of the Church throughout the Vandalic dominions at length became assured." At their advent into Africa the simple barbarians were revolted by the manners of the inhabitants; and, as soon as they had secured themselves in their conquest, proceeded to assimilate everything to their mative ideas of chastity and temperance. Within the first decade of their supremacy they had worked a general reformation at Carthage; exterminated the androgynous males, suppressed the brothels, and settled all the courtesans in a state of legitimate nuptials. ${ }^{3}$ This ideal dispensation was, however, by no means permanent, and later generations of Vindals gradually became dissolved in the luxury, and yielded to the sexual allurements which had been abolished by their stern forefathers. Thus by the beginning of the sixth century the rude nomads had been transformed into untiring rotaries of the theatre, the circus, and the chase, into revellers clad in silken vestments, who had planted themselves gardens and orchards, where they consumed their days in feasting and abandomment to sexual gratifications.'

Between Hilderic and Justinian a firm and friendly pact had been cemented during the lifetime of Justin, and the alliance was maintained from year to year by a liberal interchange of costly presents." 'The unwarlite character, how-

incensed with Maximus, who assassinated her husbant, usurped the purple, and pad her unwelcome allentions. Ciensenic married Eudocia, une of her laughters, to his son II uneric.

1 A special ecclesiastical accouns of this by l'ictur, Bishop of Vitia: De Persec. Vand.
Procopius, lice cit., 9.
"Procopius, op. cit., il, 6.
3 Salvian, of. it., vii, 22.
: llik, i, 9 .




\section{Carthage under the Romans}

ever, of the Vandal king and the defeat of his deputy by the Moors, had rendered him unpopular among his subjects, a circumstance which was taken advantage of by his consin Gelimer, a grand-nephew of Genseric, and heir presumptive of the crown. He began by assuming an arrogant state, as if he had already succeeded; and, having reduced the authority of Hilderic to a nullity, in the seventh year of his reign persuaded the Vandal nobles to elect him king in his stead. Soon the deposed monarch, with his immediate supporters, was consigned to a prison, whilst the Byzantinc alliance was repudiated as being hostile to the succession of Gelimer. On hearing of this revolution, Justinian despatched a letter of remonstrance to the usurper, urging him to allow Hilderic the nominal occupation of the throne, and to content himself for the present with the realities of kingly power. Hilderic, he reminded him, was advanced in years, so that his legitimate succession could not be long delayed. The reply of Gelimer was curt and insolent: "he had not seized on the crown, but had been duly elected by the accredited chiefs of the Vandal nation: the wisest monarchs were those who attended assiduously to their own affairs and refrained from interference with those of other people." At the same time he imposed a stricter durance on Hilderic, and blinded his nephew Hoamer, who had been his principal minister. Justinian was now deeply offended and burned with the desire to coerce Gelimer by force of arms. How the question was debated at Constantinople, and the Emperor's wishes were shaped to a reality has already been related circumstantially.

On the midsummer's day of 533 the Byzantine fleet was assembled in the harbour of the Palace, in readiness to start on its voyage to the African coast. Belisarius, the com- 


\section{The Age of. Justinian and Theodora}

mander-in-chief, accompanied by his wife Antonina and his secretary Procopius, was in occupation of the admiral's ship. As an auspicious rite a Christian proselyte, fresh from the baptismal font, was received on board at the hands of the Patriarch, who invoked the blessings of heaven on the expedition. The Emperor directed the departure from the shore, and the whole flect, following in the wake of the admiral's ship, made sail for Heraclea in Thrace. 'There they remained several days in order to complete the supply of horses, which were delivered to them from the Imperial herds pastured in that country. 'The transport service consisted of five hundred ships, in which were carried the effective force of the expedition, ten thousand foot and five thousand horse. Twenty thousand sailors manned the vessels, and, in vicw of naval warfare, they were convoyed by ninety-two roofed dromons, served by two thousand rowers.' On putting out from Heractea the royage was fully entered on: and by the judicious use of sails and oars, according to the exigences of weather and locality, the flect moved onwards to its destination. Belisarius and his staff were accommodated in three ships, which chose the course and led the way for all the rest to follow. Red sails by day and lights bornc on lofty poles at night rendered them conspicuous objects on the water. They anchored at several places on their route, and the signal for leaving port was given by the blowing of trumpets. The city of Abydos, in the Hellespont, the promontory of sigeum on the coast near Troy, Cape Malea in Iaconia, the point of 'Tatenarmm, the town of Methone in Messenia, and the island of Zacyn. thus, marled stages of their rogage until they arrived in a 


\section{Recovery of Africa from the Vandals 503}

deserted bay of Sicily at the foot of Mount Aetna. ${ }^{1}$ At Methone a lengthened stay was necessitated by the incidence of a calamity which resulted from the criminal parsimony of the Praetorian Praefect John. In his eagerness to save the cost of labour and fuel he had stocked the commissariat with imperfectly baked biscuit. After the lapse of two or three weeks this unsuitable provision fell into a state of poisonous decay, so that the troops who partook of it were seized with intestinal inflammation. Before the cause could be recognized five hundred had perished, and the spread of the disease was tardily checked by Belisarius, who procured a supply of proper bread from the shore. As soon as the Emperor had cognizance of the disaster he commended the conduct of the general, but took no steps to punish the guilty minister.

While in the Sicilian harbour a wave of doubt and depression swept over the minds of the Romans. They feared that an engagement might be imminent with a strange and formidable foe. "Where were now the Vandals, and what was their method of fighting?" was asked on every side. "Were they lying in wait to attack the expedition before it could arrive on the African coast?" The Byzantine military were scared at the prospect of a naval battle, and made no secret of their intention to avoid such a contingency by a precipitate flight. More enlightenment as to the task before them was, therefore, imperatively needed; and Belisarius decided to despatch Procopius on a mission of inquiry to Syracuse. Fortune was propitious to the messenger at the

1 The rate of movement through the water may be calculated from the statement that sixteen days were occupied by the voyage from Zacynthus to Sicily, a distance of three hundred miles; Procopius, loc. cit., 13. 


\section{The Age of Justinian and Theodora}

outsel; meeting with an old friend who was connected with the shipping trade, he found that one of his slaves present hat heft Carthage only three days previonsly. 'The man was produced and proved to be well informed as to the position in the Vandal kingdom. (iclimer was totally oblivious as to the approaching invasion, and had retired to his country house at llermione, a distance of four days' journcy from the coast, whilst the flower of his army had just departed for sardinia with the object of quetling a revolt in that island against the Vandal authority. Elated by this gratifying news, Procoprius hastened hack to the flect, which in the meantime had moved down the coast to Caucana, within twenty-five miles of Syracuse. Confidence wis at once restored hy his farourable report, and without further delay Belisarius made sail for the African coast. They were now well provisioned, unusual facilitics for the purpose haring been granted to them in sicily by Amalasumtha, the QueenRegent of Italy, with whom Justinian had entered into amicable relations. Halting on the way at Melita, they arrived at Caputrada in the province of liyzacium just three months after they had set out from Comstantinople. Carthage lay almost duc north of their position, distant by land abent one hundred and thirty miles.

A council of war was now held in order to decide as to the most adrisable method of conducting the campaign. The question for discussion was whether Carthage should le approached by lind or by sea. Arehelaus, one of the licutemant-generals, arumed that they should sail along the costst with the object of entering the stagnmm, in whose ample space the whole fleet would te effectively sheltered from wind and waves. From thence the capital could be assaluled with farility, and, in view of the unprepared state 


\section{Recoucry of Africa from the Vandals 505}

of the enemy, its speedy capture might be expected. Belisarius, however, pointed out that should a storm arise in the meantime, they must either perish on the coast or be driven far away from it; whilst in any case the delay which must ensue would give the enemy time to collect his forces. He also dwelt on the fact that his men had already asserted their determination to fly rather than fight a maval battle. He counselled, therefore, that they should forthwith disembark, with all their arms and horses, and fortify themselves in a camp on the shore. The advice of Belisarius was unanimously approved and immediately acted upon. At the outset their spirits were raised by a fortunate occurrence which they regarded as a typical omen of their future progress. In digging the trenches they struck a copjous supply of water, a phenomenal circumstance in Byzacium, which was an exceptionally arid region. ${ }^{1}$ As to the flect, a small complement of each ship's company was left on board, just sufficient to navigate the vessels or to repel a hostile attack.

The next step of Belisarius was to take possession of Syllectun1, a seaport which lay about thirty miles to the north. The town, like all others in Africa except Carthage, was unwalled in accordance with the policy adopted by Genseric, who had rased all fortifications throughout the country." The capture, therefore, was facile, and was accomplished without bloodshed. Here the general produced letters from Justinian explanatory of the invasion, and caused reports to be circulated which were likely to enlist the support of the inhabitants. 'To the Vandals he said that they

1 Procopius again refers to this miracle, as he seems to think it, many years after; De Aedif., vi, 6.

2 Procopius, loc. cit., 5, I5; cf. De Aedif., vi, 5. 


\section{The Age of Justinian and Theodora}

had come merely to vindicate the rights of their legitimate king, who had been dethroned by a usurper; to the Romans, upon whose racial and religious affinities he counted, that the army would pay its way and no forcible seizure of private stores would be made. A favourable impression was at once created, and the procurator of the public posts handed over to Belisarius all the horses at his disposal.

The march towards Carthage was now begun at the rate of ten miles a day, with a methodical disposition of the troops. Two miles in front they were preceled by an adranceguard of three hundred horse under John the Armenian. On the left six hundred Huns, all mounted archers, at an equal distance, kept watch against a surprise. To the right their safety was assured by the proximity of the seat and on that side the fleet was ordered to follow the movements of the army as they adranced along the coast. Each night a camp was formed or quarters were taken up in such towns as were conveniently situated on the route. Proceeding in this manner they passed through Leptis and Hadrumetum, and arrived at Grasse, which lay within forty miles of the capital. Here they found a palace of the Vandal kings, in the orchard of which they encamped amid trees laden with fruit in such profusion, that after the soldiers had regaled themselves there was no perceptible diminution of the supply.

In the meantime Gelimer had news of the invasion, whereupon be sent an order to his brother Immatas at Carthage to slay Hilderic with all those affiliated to him, whilst he himself was to lery an army of the best attaimable materials at 1)cimum, a suburb less than ten miles out from the city. Simultancously the usurper started from Hermione with all his arailable forces in pursuit of the Romans, of whom he happened to be in the rear. 


\section{Recovery of Africa from the Vandals}

On the evening of his halt at Grasse scouts sent out by Belisarius collided with parties of Vandals on a similar errand, and thus did he first become cognizant that the enemy were active at his beels. The Byzantines continued their forward march, and in four days came to a stand in sight of Decimum. For a short time previously they had been out of touch with the fleet, as the coast had become broken and precipitous, whilst now their ways were divergent; but Archelaus, who was in command, had been instructed to round the Hermaean promontory and come to anchor in a position not less than twenty miles off Carthage.

At this juncture the Ronans were beset by three divisions of the Vandal forces, but, owing to a want of concerted action, the combination failed. Ammatas sallied forth from Carthage, his troops straggling after him in detachments, and was unexpectedly brought up by the advance guard of three hundred. A sharp skirmish ensued; the Vandal leader was slain, his men fled, communicating their panic to those who were following on, and thus all returned to take refuge in the city. On the left Gibamundus, a nephew of Gelimer, at the head of two thousand cavalry, fell in with the Hunnish horse, who charged them incontinently and put them to flight with great slaughter. The Vandals were, in fact, stricken nerveless at the sudden appearance of these warriors, whom they had never encountered, but who were known to them by reputation. Before the news of these engagements could reach him Belisarius had gathered all his cavalry about him, and advanced from the camp in expectation of meeting the enemy. He ordered a considerable part of his forces to explore in front, and these, after no long march, found themselves in sight of a great concourse of horse commanded by the Vandal king in person. A desultory conflict, 


\section{The Age of Justinian and Theodora}

in a region diversified hy low hills, followed: the barbarians attacked with skill and bravery, and in the result the Byzantines were routed, nor did they relax their flight until they succeeded in rejoining Belisarius. It this moment the randals might have been rictorious had they been led by a seneral who knew how to concuer. But Gelimer, neglecting his advantage, abandoned himself to lamentations for the death of his brother, of which information was just then brought to him, whilst the Roman general rallicd his troops and bore down upon his adrersaries with irresistible vigour. The Viandal leader, with all his forces, now fled indiscriminately, and, solicitous only for immediate safety, chose the unfrepuented road to Numidia instead of retiring strategically on the caprital.

belisarjus was now master of the situation, though himself unaware of the full extent of his success. Within Carthage, in fact, owing to the great preponderance of the Roman element, a bloodless revolution had already taken place. The gates had been thrown open on the Vandal defeat becoming known, and, at the sight of the flect in the offing, the chain of the harbour had been withdrawn, whilst the bulk of the citizens awaited with joyful expectation the moment when they' might fraternize with the victors. 'The Vandal officials fled into hiding or sanctuary; the gaoler of the prison on the citadel unbolted the doors and gave exit (1) all the political suspects whem the distrust of Gelimer had incurcerated: and even the Arian cleres abandoned their churches to the possession of the Orthodox lishops. Next day the Kommon general broke up his camp, and, still keeping his line of battle, advanced with considerable caution to the cippital, where at tengeth he realized how completely he had won the day. A portion of the flect was already 


\section{Recovery of Africa from the Vandals 509}

moored in the Mandracium, the patency of which had been discovered accidentally through the temerity and disobedience of one of the subordinate officers. " The soldiers were received into quarters throughout the town, while Belisarius, with his staff, ascended the Byrsa and established himself in the royal palace. ${ }^{2}$ The same evening a banquet was spread for the Romans by the servants of Gelimer, when the victorious general occupied the throne of the defeated king.

Belisarius now applied himself energetically o restoring the fortifications of Carthage, which had fallen into a ruinous condition, as he felt assured that before long he would have to defend his conquest against a siege. In an incredibly short time he repaired all the breaches in the walls, and surrounded the city with a fosse protected by a stout palisade. His foresight was amply justified, and it wis soon found that the outlying districts were beset by the adherents of Gelimer to such an extent that no Byzantines could venture outside the city without the certainty of being cut off by some hostile band.

In a few weeks the Vandal king had collected a force

1 The sailors refused to hold off as Belisarius had directed, asserting that a "Cyprian" was imminent (an easterly gale). Hence Archelaus reluctantly steered for the Stagnum, but a lieutenant, on his own responsibility, made a bold dash for the Mandracium; Procopius, loc. cit., 20.

2 The gaol, as usual, formed part of the paiace, and both were on a lofty site, which can scarcely have been other than the Byrsa. The position is clearly indicated by some of the details. Thus the gaoler came to the prisoners and said, "What will you give me if I release youl?" All promised, according to their utmost ability. "l ask nothing," said he, "but that you promise to befriend me should you hereafter see me in danger." Thereupon he unbarred an outlet and showed them the Roman fleet crossing the bay. Forthwith he opened the prison, and all went off together; itid.

II.

L L 


\section{The Ase of Justinian and Theodora}

which he deemed sufficient for the recovery of his capital; and, moreover, he attacked the city insicliously by means of secret emissaries whom he employed to seduce the allegrance of the Arian harbarians, who were numerous in the Roman army. His camp was situated at bulla on the Numidian frontier, about one humdred miles to the west of Carthage. Here he awated his brother Tzazo, the leader of the Sardinian expedition, whom he had summoned to take part in the war against the invaders. His approach was signalled, and, as soon as a landing was effected, the impulsive barbarians threw themselves into cach other's arms and bewailed with tears and lamentations the sudelen misfortunes which had overtaken their race.'

The siege of Carthage was now begun, and Gelimer's first hostile act was to cut off the main water supply by making a breach in the aqueduct. No military assault was attempted, nor did the Vandals raid the country, as they looked on everything as their own property. A passive belcaguerment, by isolating the inhabitants from the outside world, semed to them to be sufficient to bring about the submission of the capital. leclisarius on his side at first maintaned an equal quietucle, eleferring active measures until the walls had been fully consolidated. Ile was also distrustful of the Ituns under his conmand, whose murmurs against their protracted atsecuec from home atugured itl for their loyal bearing in the crent of a battle.

Afeer the lapse of a ferv weeks the fortifications were renclesed secure, and then the bysantine seneral marched out with all his forees to seck the cuemy. Ciclimer's encampment was soom discosered to le at lricamerum, seven-

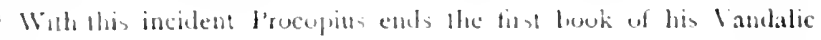
11 . 


\section{Recovery of Africa from the Vandals 5I I}

teen miles beyond the city. Belisarius hastened to the spot with all his cavalry, which on his arrival he disposed in three divisions opposite the hostile camp, he himself occupying the centre with his standard-bearer. The Huns drew themselves up apart, according to their custom, and in this instance meditated treachery should the fortune of the day prove adverse to the Byzantines. The infantry were halted at some distance in the rear. A rivulet now separated the two armies, and on the following morning the Vandals ranged themselves in order of battle on the opposite bank. Tzazo, with the veterans from Sardinia, led the van, whilst Gelimer rode along the line exhorting his troops to rely solely on their swords. First of all the Armenian John, with a small band, dashed aeross the stream against the Vandal centre, but was repulsed. He returned to the charge with a larger following, and was again repulsed. For the third onslaught Belisarius undertook the attack in person; the Romans sent up a great war-shout, and the Imperial standard was swept along as the whole centre drove down impetuously on the barbarians. A powerful impact resulted; the Vandals made a strenuous defence, but Tzazo was soon slain, whereupon they desisted and betook themselves to flight. All the Roman horse now put themselves into motion, including the vacillating Huns, and the enemy were hotly pursued, until they saved themselves by plunging into their camp. This victory cost the Byzantines only fifty men, but of the Vandals eight hundred fell.

On the evening of the same day Belisarius advanced with both horse and foot to assault the enemy's camp. On arriving he found, however, that Gelimer had hurried away secretly with a few friends, intent on hiding himself in the recesses of Numidia, and that the Vandal host, on per- 


\section{The Age of Justinian and Theodora}

ceiving themselves to be deserted by their King, had dispersed, eager only to preserve their lives. 'Thus the derelict camp, with its whole contents, became the immediate prize of the victors. It was found to be replete with wealth, the accumulated treasures of the Fandal mation, which had been amassed during the raids of Genseric on every part of the Roman dominions. Such an immense hoard of money; it seemed, could never before have heen brought together into one repository. Pillage now became the sole object of the Byzantime soldiery, all discipline was ignored, and the army was only discermible in the form of numerous pairs of companions who overran the district engaged in rapine. 'This abandonment continued throughout the night, and at dawn Belisarius, with great difficulty, collected his men, when all returned to Carthage laden with immense booty. Besides valuables, the seizures comprised women and boys, all men who seemed to belong to the hostile nation being butchered. It was now the middle of Dccember, and just three months since the Byzantines had entered the African capital.

To secure the person of Gelimer was a matter of prime importance, and John, the Armenian, with a company of wo hundred, had been despatehed in pursuit of the fugitive. For five days they hurried after him on his track, and then, by a deplorable mischance, the leader was ransfixed and mortally wounded by an amow discharged from the hand of one of his own men. Belisarius wis at once informed, and hastened to the locality, hut the mavoidable delay enabled the flying king to make gounl his escapes. On incuiry, it was elicited that he had taken refuge among the Moors of l'appua, a rugged and almost inacessible mountain in a remote corner of Numidia. Belisarius followed on, and, 


\section{Recovery of Africa from the Vandals $5 \mathrm{I} 3$}

having made a survey of the stronghold, decided that it was impregnable to an attack. He therefore appointed one of his officers, Pharas, a Herule, to blockade the outlets and cut off supplies to the refugees. He himself returned to Carthage by way of Hippo Regius, where he had the good fortune to capture the reserve treasures of the Vandal King in a weather-bound ship, which had failed to convey them to the custody of Gelimer's ally, the King of the Visigoths in Spain. Belisarius now sent a legate to Sardinia and Corsica, who displayed the head of Tzazo, and secured the submission of those islands to the suzerainty of Justinian. Wherever the Vandals had ruled missions were despatched to announce the circumstances of the conquest, and thus the whole of North Africa, together with the islands of Ebusa, Majorca, and Minorca, were transferred to the dominion of the Eastern Emperor.

In the meantime the blockade of Pappua had been rigorously maintained, and Gelimer had been reduced to the greatest straits for the want of proper provisions. At length Pharas expostulated with him on his obduracy, and tempting proposals were made to him should he surrender himself to the clemency of Justinian; the rank of a Roman patrician fortified with a liberal endowment of lands and money. Gelimer replied that he would never accept a favour from one who had conquered him in an unjust war, and implored the officer not to aggravate his sufferings by the repetition of such offers. His letter concluded with the words, "I beg of you, my dear Pharas, to send me a lyre, a loaf of bread, and a sponge." At a loss to understand this seeningly strange request, Pharas interrogated the messenger, who explained that the musical instrument was required in order to accompany a dirge in which the 


\section{5it The Age of Justinian and Thiodora.}

Vandal King bewailed his misfortunes; that the hard fare of the Moors did not include such a luxury as baked hread; and that the sponge was intended to bathe the eyes of the sufferer, which had herome inflamed by wecping. 'The olticer rompassionately acceded to the prayer, but maintained his guard as strictly as before. After the lapse of three months the pride and resentment of Gelimer became subdued, chiefly through his being a spectator of the hardships entailed on those who had attended him to his comfortless retreat: and he signified his willingness to resign himself to the custody of belisarius. He was conducted to Carthage, and shortly afterwards the Byzantine leader, with his principal captives and all the spotils of the war, set sail for Constantinople. Belisarius was, in fact, glad that the lime had come for him to take his departure, as envy and slander had lately begun to le rife about him; and it was insinuated at Court that he had assumed a regal state, as if he contemplated an independent sovereignty, a line of conduct which was wholly forcign to his temperament and aspirations.

The gend foltune which attented belisalus, and the forluitous character of most of his success in this campaign will be crident in the most superficial reater. The liyzantines themselves seem to have leen

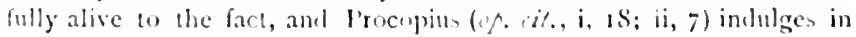
some reflections which may be exactly represented ly the worls of Hamlet $(v, 2)$ :

\section{"Kashly,}

Anel pratecel le rabness for it, led us know,

Otr indincretiuns sometimes verve us well,

When our elecp plots do pall: and that shenlel teach u.

Jhere" a divinity that hapes our elul,

knugh.hew them how we will."

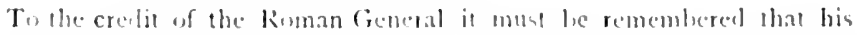

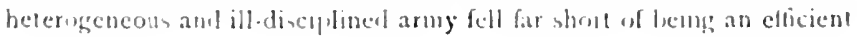




\section{Recovery of Africa from the Vandals 515}

On an appointed day in the autumn of the same year a scene was enacted in the Imperial capital which recalled the triumphs of former ages, but so modified as to exalt the glory of the Emperor far above that of his most conspicuous subject. Belisarius, accompanied by the deposed King, his relatives and nobles, moved through the city, on foot, at the head of a procession in which were displayed all the precious resources and costly appurtenances which illustrated the recent magnificence of the Vandal Kingdom, and were now become the prize of the conqueror. Golden chairs, state carriages, a profusion of sparkling gems, cups of gold, all the appointments of the royal banquets, myriads of silver talents, and the heirlooms of plate which had adorned the palace, were borne along the streets to the Hippodrome, in the area of which they were accumulated to make a dazzling exhibition. Among them were the spoils

fighting machine; but he secms to have incurred neerless risk both at Decimum and Tricamerum by drawing his cavahy away from his infantry, whilst his being unaware for many days that he was surrounded by the enemy's troops on the march from Caputvada seems wholly inexcusable. But the incapacity of Gelimer to lead an army with skill and determmation, his want of foresight and unpreparedness, neutralized the gravest errors. The water was left open for the enemy's fleet at a time when the semblance even of an attack by sea would have clispersed them for good. He failed to push his splendid success at Decimum, and on the night after Tricamerum, when a muster of the Vandal troops might have annihilated the Roman forces in detail, he had deserted the scene of action. Again, the task of Belisarius was much lightened by the limely revolt of Sardinia and by a simultaneous rusing in Tripoli, whereby the resources of his adversary were considerably diminished. Though of little moment after the land successes, the preservation of the Byzantine fleet was clue, perhaps, to its making for port, in opposition 10 the injunctions of Belisarius, instead of remaining exposed on the incommodious coast. For an exhaustive critique of the campaign, see Pflugk-1lartung, Belisars Vandalkrieg, Iist. Zeitschrift, Munich, I889. 


\section{I6 The Age of Justinian and Theodora}

of Jerusalem, translated to Rome hy Vespasian and 'Titus,' and afterwatsels pillaged from thence by the insatiable Censeric, who carricd them off to Carthige. Justinian sat aloft upon his throne, and (ielimer, still invested with the insignia of a King, was conducted to his feet. There he was stripped of his purple robe and forced to kiss the ground before the triumphant monarch. Niter his illustrious captive the victorious general rendered a similar homage to his Imperial master. Throughout the ceremony the Vandal King maintained a dignified composure, but he repeated aloud continually the words of scripture, "Vinty of vamities, all is vanity." Subseyucutly ample cstates i1. Galatia were conferred on him, but the patriciate was withheld, as he declined to abjure his Arian faith. All the scions of Vandal royaly had been transported to Constantinople, and among them were the daughters of Hilderic, who in the fenale line were the direct descendants of the last Emperors of the llest. These princesses were consigned to the care of '] heodura, and the ultimate representatives of the dynasty founded by the great Theodosius became the pensioners of the fortunate prostitute." As for the treasures of the extinct Hebrew nationality, a Jewish spectator of the pageantry inferred, within the hearing of Justinian, that the retention of these sacred relics had bronght destruction to kome, and determined the doom of Carthage, whence he foreboded that the byzantine capital would fall under the bats of the

70 ı.1.; Tacilu, Ilint, v; Jovephus, bel. Jud., v, vi, elc. The olject were ligual in the Arch of Titus, lle mest consplicuous lesing the wereb-lirancheel cantlentick.

- See 1' ;00. Their mother was Eudocia, daughter of Valentinian III

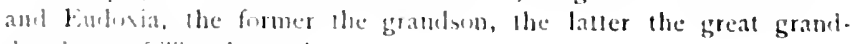
dutughter, if lineodosas 1. 


\section{Recovery of Africa from the Vandals $5 \mathrm{I} 7$}

Almighty should they remain inside its walls. No restingplace, he asserted, would be found for them unless where Solomon had consecrated them to the worship of Jehovah. The Emperor was struck by the admonition, and decided to divest himself of these fateful valuables by sending them to be deposited in the Church of the Holy Sepulchre, at Jerusalem. In the following January Belisarius was honoured with the Consulship of the year (535), and a large amount of the booty, which had fallen to his lot at Carthage, was distributed as largess among the populace. His reputation had now risen to such a height that he seemed to be too great to remain in the position of a subject; and the Imperial couple thought it prudent to extract from his complaisance a solemn pledge that he would never aim at the sovereignty during the lifetime of Justinian. ${ }^{1}$

When it was reported to the Emperor that the Kingdom of the Vandals was overthrown, he at once drew up a scheme for the local government of this accession to his dominions. A third Practorian Praefect, with a salary of $100 \mathrm{lb}$. of gold $(£ 4,000)$, was created to administer the Diocese of Africa, as it was now denominated. His official seat was at Carthage, and under him seven Rectors were nominated to rule the minor divisions of the country. ${ }^{2}$ The island of Sardinia was included in this disposition, and formed a separate province. ${ }^{3}$ The civil and military powers were kept apart, and a Master of Soldiers, with five local Dukes, was appointed to command the army corps required for the protection of the Diocese. ${ }^{1}$ The Roman system of

1 Procopius, De Bel. Goth., ii, 29.

${ }^{2}$ Cod., I, xxvii, 1.

3 The two Mauritanias were conjoined.

${ }^{4}$ Cod. I, xxvii, 2. This is an elaborate act descriptive of the new administration, and dealing with the duties and pay of its several 


\section{IS The Age of Justinian and Theodora}

tavation bad been suppressed hy Censeric, and under the Vandal supremacy the imhabitants had heen almost relieved from the burden of the imposts; but on the restoration a pair of legothetes were commissioned to survey the country, and assess the population for the benefit of the treasury. Much displeasure was felt by the . Nricans at this recurrence to the old methods of exaction, which they had berme oblivious of during their remission for nearly a century:

Although the Vandal power in Africa was annibilated by the victorices of belisarius, the peaceful settlement of the l)iocese was deferred for more thim ten years owing to the insulordination of the army of occupation and the unwillingness of the Moors to submit to the liyrantine yoke. In two instances leaders of the rebellious soldiery promoted a mutiny with such effect that for the time being the recent concluest was virtually severed from the limpire. The episodes of Stotzas and Gontharis may he briefly recounted.

I. In the first sedition three distinct parties were conjoined, who, through circumstances peculiar to each one, were inspired with animosity against the govermment. A large number of the Roman military found fortunc in Africa by the capture of wives and daughters of Vandals who were cilber slaughtered at the time or expelled from their possessions. The newcomers married these women, and installed themselves in the lands and dwellings previously beld by their male relatives. by Imperial decree, however, the

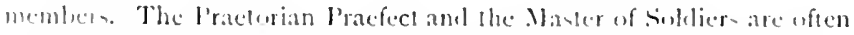
mentioned ly l'rocopius in the second luok of his Vamelalic Was. For fong the govermmen! of Afica was practically a miliary tespotism, and the civil chief was merely the first secetary of the gencral in puwer.

lencopius, of cil., ii, s. 


\section{Recovery of Africa from the Vandals 519}

estates of the conquered were confiscated to the crown; and thus the impromptu settlers in a short time found themselves exposed to summary ejection. Such was the most considerable complement of the malcontents. To these were added the Arian barbarians, numbering about a thousand, who had taken part in the expedition. The fanaticism of the latter was inflamed by the dispossessed Vandal clergy, to whom the practice of Christianity according to their heretical rites was now interdicted. The third contingent consisted of a remnant of the Vandal army, which had taken refuge in the Aurasian mountains on the south of Numidia. ' This party was made up almost wholly of fugitive prisoners of war who had been transported to Constantinople, whence it was decided to distribute them among the garrison towns of the East. They were despatched by sea to their destination, but on arriving at Lesbos about four hundred of them seized the ships in which they had been embarked and made good their escape to the African coast. Communication and conjuration between the first two sections was established at Carthage, and it was agreed that on Easter Sunday (536) Solomon, the Master of the Forces, who had replaced Belisarius, should be assassinated in church. The rebels would then seize the reins of government. The secret of the conspiracy was well kept, for even the unaffiliated reserved their suspicions, being privately elated at the prospect of

1 "The Aurasian mountains," says Procopius "resemble no other place on earth. They have a girth of three days' journey, and on all sides the ascent is precipitous. On the top is a level plain easily traversed, liversified by flowery meadows, gardens planted with trees, thickets of aromatic shruls, fountains gushing from rocks, and rivers rolling noisily into still lakes. The fertility is admirable, luxuriant crops and trees laden with fruit are produced here in an abundance unknown in any other part of Africa "; De Aedif., vi, 7; De Bel. Vand., ii, I3. 


\section{The Age of Justimian and Theodora}

rapine; but the assassius elect shrunk from perpetrating the murder on the first, and even on a subsepucant occasion. Noisy recriminations in the public places followed, and it hecame evident to erergone that there was a plot. The conspirators now threw off all disguise, having discovered that they were in a miljority, and applied themselves to looting the rity and suburbs. Solomon, with Procopius as his companion, ander cover of night fled to the coast and mate sail for Syracuse, where belisarius was known to be chngeged on a mission. The three returned with the ntmost speed, and found that the rebels to the number of eight thotsand, including the fugitive Vandals, had massed themselves on the plain of Bulla. They had chosen as their leader a guardsman of vigorous character named stotzas. A march on Carthage was contemplated, but Belisarius, having levied as many loyal troops as possible, intercepted the project and forced them to give battle. Although his forces were quad. rupled by those of the enemy, the prestige of his manc, their indecision, and an adverse wind which blew in their faces, enabled him to win a victory. 'The sedition, however, was merely demulecd for a time and belisarius had to return immediately to sicily. Iater on Iustinian despatched his nephew Germanus to Africa, and this general, by tact and blandishments, succeeded in winning bate nearly half of the supporters of Stotzas. I hatele was fought in which the retel leader was mterly defeated and his followers scattered, with the loss of all the valuables they had collected in their camp. Stothas himself fled to Mauritaniat where be settled down with a datughter of one of the petty princes ats his wife; but a few years afterwards (545) he reapleared in arms, lighting on the side of the Moors. In an encounter he was slain tragically by the Koman general opposed to him, who 


\section{Recovery of Africa from the Vandals $52 \mathrm{I}$}

pierced him with one of his arrows, but was himself struck down forthwith by a mortal wound. The two antagonists expired almost in sight of one another, each one expressing his welcome acceptance of death in view of the gratification afforded by that of his rival. ${ }^{1}$

2. About this time Areobindus, the husband of Justinian's niece Prejecta, was appointed to be Master of the Forces in Africa. He was a man of a timid disposition, and totally unversed in war, to such an extent that he had never been present at the most trivial engagement. Under this inefficient hegemony, Gontharis, Duke of Numidia, aspired to be a despot with the aid of the factious soldiery and the Moorish insurgents. By a league with Antalas, the most potent of the native chiefs, he agreed to surrender to him the province of Byzacium and half the treasures of Areobindus as the price of his support in making himself king over the rest of the country. At first he proceeded insidiously and associated amicably with the Master of Soldiers at Carthage, where he simulated a capture of the city by the Moors in the hope of so terrifying Areobindus that he would see nothing left but to escape by flighi to Constantinople. This project was just baulked by the sudden rise of a tempest, which arrested the departing general. Shortly afterwards the designs of Gontharis were fully penetrated, and he thought it wisest to proclaim himself boldly as the head of the government. An attack on the usurper was then organized, and the hostile bands met in the precincts of the palace; but at the sight of the first blood drawn Areobindus lost his nerve and fled to a fortified monastery near the harbour. Gontharis was now supreme, and received the submission of all the officials in

Procopius, De Bel. Vand., ii, I4-17, 24. 


\section{The Age of Justinian and Theodora}

the capital from the Practorian Prefect downwards. The late commander-in-chief was lured from his retreat by threats and a promise of safe dismissal to Constantimople with his houschold and property. He presented himself to the despot in the dress of a private citizen, leaning on the bishop as he held forth a (iospel, and made an abject profession of his acpuicseence in the situation. Fomtharis treated him deferentially, and retained him to supper the same evening. After the meal, howerer, he went ont and sent in the captain of his guard, who slew him, regardless of his pitiable appeals for mercy. Africa was now to all appearances restored to independence as completely as if the conquest had never been achieved by Belisarius. The tyrant next attempted to substantiate his position by forming an alliance with Prejecta, whom he induced to send letters to the Emperor, in which the murder of Areobindus was represented as the wanton act of an insolent subordinate. But the foundations of his authority were insecure, and a counter-conspiracy was soon formed by the adherents of the Imperial government, whose allegiance was a mere pretence resorted to under the pressure of expedienry. Among those who affected to support him rordially was Artabanes, the commander of an . Imenian regiment, and a deserter from the l'ersian service, in which he had risen to some distinction. He and his associates Nere ambitious of recosering Africa for Justinian, and they concerted a plot for the assatssination of (iontharis during a bancpuet. Artabanes had been imvited by the usurper, and he: entered the dining hall attended by two or three of his stuards, whese customary duty it was to stand behind their master's comch during a meal. A mumber of their fellows he desired to biter alust the approaches, miximg with the sllards of the palace, as if wating on his orders. 'The soldiers in the 


\section{Recovery of Africa from the Vandals 523}

city, when not equipped for war, were forbidden to wear defensive armour, and allowed to carry only a sword. To obviate this difficulty, Artabanes instructed his men to make a pretence of playing with the shields of those on guard in the vestibule, as they lay ready for use, but to snatch them away altogether should they hear any commotion within. It had been agreed that Artasires, one of the guards in waiting at the couches, should strike the first blow; and he ingeniously protected his left arm by fastening the halves of a split arrow-shaft inside the sleeve of his tunic. At a certain moment it was judged that Gontharis was obfuscated by his potations, signs passed, and then Artasires, sidling towards him with his drawn sword hidden under his arm, aimed a sudden stroke at his head. In instant counter-stroke by the contiguous guard of the despot was parried by his shielded arm, and the man was laid low by a return thrust. Simultaneously Artabanes had sprung up and finished Gontharis with a stroke of his sword as he attempted to rise from his couch. A general clash of arms ensued, and many not in the plot joined the liberators. The rebel guards without, deprived of their shields as planned, were massacred, and soon a cry of "Justinian the Victor" was sent up. A raid on the adherents of the usurper was then undertaken, and they were exterminated in every part of the city. The tyranny of Gontharis had lasted only thirty-six days. Artabanes won great renown by this exploit, a splendid donation in money was bestowed on him by Prejecta, and shortly afterwards the Emperor's commission arrived, creating him Master of the Forces in Africa. To his immediate petition, however, Justinian conceded him the equivalent of his rank at Court, and he left the country without delay. He was, in fact, enamoured of the young princess (she is referred to as a girl), 


\section{The Asce of Justinian and Theodora}

or, at least, of her Imperial comnection, and he eagerly followed her when she returned to Constantinople.'

For fifteen years after the conquest of the vandals contimual uprisings of the Moorish clans troubled the settlement of Africa, and a fitul warfare, sometimes furious, was waged ferween them and the limpire. Swarms of these nomads often appeared in the field, hut their jealousy and distrust of each other was so imveterate that their forces could on no occasion le mustered to act in combination. Their intermecine feuds were never allayed, and during most of their revolts great hosts of them elected to fight as allies of the byantines in order to suppress the efforts of their own kin. On each side more than one hundreel thousand often appeared in arms simultaneously, but to the elisciplined and mail-clat soldiers of the Empire their martial equipment always seemed contemptible. Notwithstanding their contiguity to the Komans for so many centuries, they had not profited by their olservation and experience to imitate the methods of worfure which had imsuriably proved effectual against themselves. A burnous of white linen enveloped their head and body, leaving the legs and arms have; a small leather shiekd formed their sole defensive armour: and their only weapons of antack were a short sword and a couple of javelins." When at war atl the members of a tribe, accompanied by their flocks and herets, marched in conjunction to the hatte-ficle. To the women was entrusted the duty of tending the cattle, sharpening the weapous, lomilding huts, and entrenchung the camp. A great rircle was enclesed by a living lampart consisting of the elonestic mimals. Extemally ranks of amets, linked rogether awelse deep, formed the main defence; 


\section{Recovery of Africa from the Vandals 525}

within were ranged the oxen, sheep, and goats. Women, children, and old men, in charge of whatever valuables they possessed, were congregrated in the central space. ${ }^{1}$ At the approach of an enemy the Moorish infantry packed themselves in the interstices of the camels' limbs, whilst the cavalry took advantage of whatever cover was afforded by the adjacent woods and hills. On the arrival of the hostile troops javelins were hurled from the entrenchments, the warriors on horseback poured down on each side to assail the enemy's flanks, and the women flung stones, balls of lead, and lighted torches from the interior of the camp. Horses were repelled by the sight and scent of the camels, and refused to carry their riders forward to the attack. Under the circumstances the only expedient was to dismount the cavalry and assault the men and animals determinedly on foot. On one occasion Solomon, by the slaughter of about two hundred camels, cut his way into the camp, whereupon the Moors fled precipitately in all directions. ${ }^{2}$ On another, the enemy had posted themselves in immense numbers on the level top of Mount Burgaon, but the Romans climbed the sides during the night, and at break of day suddenly appeared above the crest on both sides of the horde. A panic ensued, and a wild rush was made in the direction of a proximate summit. But the fugitives were intercepted by an unsuspected gulch, into which all dashed headlong, urged by the irresistible pressure from behind. Men and horses rolled down until the gap was filled to the level of the opposite side. The rest then saved themselves by passing over the bodies of those who had perished in this manner, to the number, it was estimated, of 50,000. ${ }^{3}$ After

1 Procopius, De Bel. Vand., i, 8 ; ii, II.

2 Ibid., ii, II.

${ }^{3}$ Ilid., 12.

11.

M M 


\section{The Age of Justinian and Thiodora}

such victories all the occupants, contents, and constituents of the camp became the prize of the conquerors; and the slave market for Moorish captives at Carthage was so overstocked that a youth could be purchased for the same price as a sheep.' 'The fumal pacification of Africa was due to John Troglita, the successor of Artabanes, who, in several campaigns extending over three years, inflicted many defeats on the Moors, and drove the most turbulent tribes beyond the Roman rontier." His decels of valour provoked so much almiration among the Africans, and were of such signal benefit to the country, thit one of their number, Cresconius Corippus, was impelled to celebrate his career in an epic poom designed to place him in the same niche of glory as the heroes immorialized by Homer, Virgil, and Claudian."

As a result of his conquest of Africa, Justinian came into collision with the Visigoths of Spain, an event which led to a permanent occupation of a portion of the south-east coast of that peninsula by the Byzantines. The castle of Septem, on the headland to the south of the Straits of Gades, was in the hands of these barbarians, wherefore a brigade was sent by Belisarius to capture it." Shortly' after they had succeeded

1 Procopius, De Bel. Vand., ii, 12.

$\because$ Nivt., 2S: De bel. Cinth., iv, 17. Among the innumerable Johns of this age he $\mathrm{j}$; distinguishert ly l'rucopius as " the lisuther of l'appus," and by Jurclanes (I)e lieg. Siuc.) as "Truglita."

3 The lothannis, in eight lonks, thut the latter part is lost. It contains much information revecting the Moors and lheir mole of fighting, lus exactibute is generally sacriticed to the necessary raguity of poetical description. Important works ly Cagnat (l'aris, IS92) amd Pallu de lessert (laris, ISg6) on Koman Africa lerminate at lle lambl conpue-t.

- I'rocopius, De lict. Vand., ii, 5. 
in doing so, Theudis, King of the Visigoths, despatched a counter expedition against the Byzantines, but this force was soon destroyed through being attacked unexpectedly on a Sunday. ${ }^{1}$ Nearly a score of years afterwards a religious war broke out in Spain through the Arian King, Agila, wishing to coerce his Catholic subjects, whom he besieged in their principal stronghold of Cordova. The leader of the rebels was Athanagild, and, as the Roman prestige was now supreme in the West, as well as because of the religious affinity, he applied to the Emperor for aid against the Arian persecutors. ${ }^{2}$ Justinian responded, and sent Liberius, ${ }^{3}$ a general who was then engaged in the reduction of Sicily, 'with the result that Agila was soon defeated and slain. ${ }^{5}$ The Visigoths at once surrendered, and elected Athanagild as king, whereupon a compact of tolerance was ratified between the two parties. ${ }^{6}$ They now wished to dispense with the services of the Byzantines, whose proceedings struck them with alarm, as, instead of preparing to evacuate the country, they seemed to have settled themselves permanently in those fortresses to which they had gained admittance through their alliance with the Catholics. A summons to depart having been disregarded, a petty war ensued; and, although the King gained some battles, he was ultimately obliged to acquiesce in the Byzantine occupation of several notable cities $^{\top}$ on the south-east coast, among which were Carthagena,

${ }^{1}$ Isidore of Seville, Hist. Goth. (Mommsen, Chron. Minora, 1877), p. 284 .

2 Ibid., pp. 286, 475 .

${ }^{3}$ Jordanes, De Reb. Get., 58.

- Procopius, De Bel. Goth., iii, 40, etc.

${ }^{5}$ Isidore Sev., loc, cit.

- Ibid.

7 Ibid.; Gregory of Tours, iv, 8. 


\section{${ }_{52 S}$ The Age of Justinian and Theodora}

Cordova, and Maliga.' Such are the facts, so far as they are known, relating to this campaign, which is sometines dignified by the title of "Iustinian's conquest of Spain."

1 See II. (ielzer ad George (propery Gregory) of Cyprus, p. xxxii, it reg. Surmise rather than fact. (Teubner.)

- Il will he seen from the references given that none of the Byzantine historians, not l'rocopius, nor In. I.ydus, nor Agathias, secms to have harboured a supicion that Juninian ever "conquered" spain. The latler, however, names spoin indidentally among the places where tropp were stationed (r, I3). 


\section{CHAPTER IX}

THE BUILDING OF ST. SOPHIA: TIE . IRCHITECTURAL WORK OF JUSTINIAN

W

HILST it is evident that the distinctive character of Justinian impelled him to be incessantly active in every branch of the monarchical profession, the devastation wrought at Constantinople by the Nika rebellion might have awakened a passion for building in the breast of the most phlegmatic Emperor.' A mass of sightless ruins had taken the place of those architectural adornments which are the essential feature of a capital and the foundations of the dignity of a throne.

The restoration of the precincts of the Palace was the most pressing necessity, and Justinian applied himself to the task without a moment's delay. At the same time he determined that the new buildings should surpass in beauty those which had been destroyed, and he devoted himself to the restoration of the great metropolitan church with especial zeal. More fortunate than Constantine, he had not to complain that architects of reputation were undiscoverable; and in Anthemius of Tralles and Isidorus of Miletus, ${ }^{2}$

1 See pp. 459, 462.

2 Some personal and family details of these professionals are griven by Agathias, v, 6-9. He also recounts an ancedote which shows that some- 


\section{$53^{\circ}$ The Ase of Justinian and Theodora}

he found men who were capable of conceiving and exceuting great designs. Neither history nor modern research enables us to explain with fulluess the origin and erolution of that variety of ecclesiastical butleling which is recognized as typically Byeantine, and of which the church of st. Sophiat, crected by Justinian, remains to the present daty as the only decided prototyle. The accounts which have come down to 11 s of the construetion of this edifice indicate clearly that the architects engaged in the work were attempting to do something which had not been done before; or, at least, that their design, if not original, had never to their knowledge been put into practice on so large a scale. Failure, therefore, was a contingency with which they had to reckon, and, until their scheme was completed, they had to be prepared to modify or eren to ibandon their plan.'

thing of the pewer of sleam was understond in those days. It appears that Anthemius hat a nexl-elese neighlusur, a rich mon, who incom. moded him by arlditions an his mansion which interfered with eome ancient lights, ele. The archited determined to revenge himself ly cerrifying the oftenter while in the act of entertaining a party of friends at a hanquet. For this purpose he hit on the experlient of carrying pipes from larece covered caldenti ind the rouf of the mansion, where be practied every wutlet, and at at thling moment applied fire to the vensels when full of water. Thu, after the steam began lo riee and high pressure wan induced in the contined space, a great commotion was recasioned

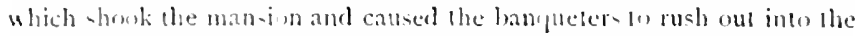
strect exclaiming that there was an carliequales. Subsequently, when

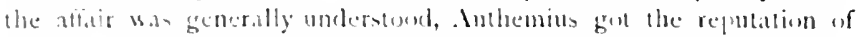

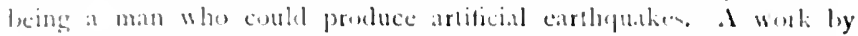

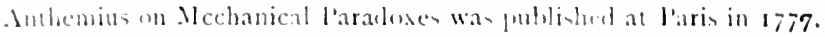

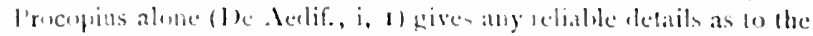

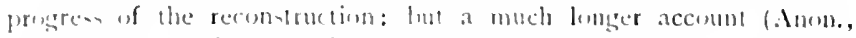
latmluri and (colinu, differmg wmewhat) comproel in a later age

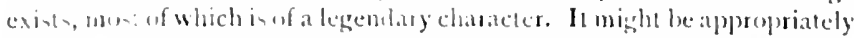

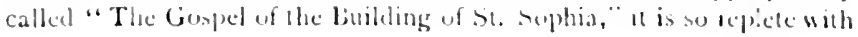




\section{The Building of St. Sophic}

The Emperor had resolved that the proportions of the new church should be much greater than those of the old one, and therefore the extension of the site was the first requirement of his undertaking. On the south side the ground was clear, but the open space of the Augusteum barred any encroachment in that direction. On the other three sides, however, the area was hemmed in by various buildings, and several of these were private property. Some of the difficulties encountered at the outset, therefore, arose from the obstinacy of adjacent owners, who refused to sell their lots at a reasonable price or to part with them on any terms whatever. Obstacles of this class were the origin of a crop of stories which obtained currency among the populace, who were amused by hearing of the ruses adopted to defeat the wilfulness of certain occupants. Their truth cannot now be tested, and in general they may be disbelieved; but there seems to be some foundation for the anecdote related of a widow named Anna, who stubbornly declined to negotiate for the sale of her house. Nobles waited on her without result, and at length the Emperor came in person and begged of her to name her terms. Upon this she fell on her knees and declared that she would accept no money for her freehold, but entreated him to take it as a gift to St. Sophia on condition that she should be buried in the corner of the church whereon her dwelling had stood. Her proposal was agreed to, and in after ages the area in question continued to be pointed out as the "widow Anna's lot." ' That trouble of this kind might be real

marvels, some of which read like an extract from the New Testament and others like an episode from the Arabian Nights.

1 The place was shown to a Russian pilgrim, Anthony of Novogorod (twelfth century; Soc. Orient. Latin. Sér. Géog., v). Other tales in the 


\section{The Age of Justinian and Thiodora}

enough may be inferred from the alssence of any legislation providing for the compulsory sile of property repuired for public purposes in accordance with the decision of a board of expert arbitrators.

Is soon as the architects hald matured their design for the construction of the great edifice, the collection of the materials required to bring their conceptions into sub. stantial existence was in itself an arduous task. 'The church was to be built of brick, lut its richness was to be derived from the liberal use of pillars and slabs of polished marble in every available situation. In Inperial rescript was despatched to the kectors throughout the provinces, desiring them to search their districts, and transmit to the capital any relics of ruined and deserted iemples which might be suitable for the Emperor's purpose. In response to this appeal it is particularized that eight porphyry columns, the remains of a temple of the sum, were sent from kome, and eight of green marble from Ephesus: and we may assume that a large quantity of such mementues of polytheism were amassed at Constantinople about this time, which, if not used for st. Sophia, were employed in the restoration of other parts of the disfigured city: Much new marble was, however, fluarried in various localities widely distant in order to obtain the variety of tints and variegated patterns

legendasy account refer to a cunuch who giekled wh lecing loched up to fresent his secing the Concus gamen, and to a colliler wher stijulated to lice salued as limperess, ctc.

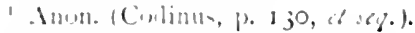

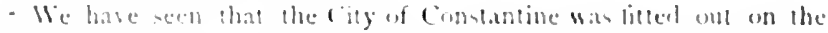

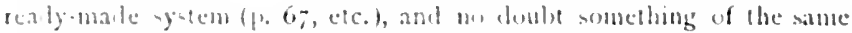

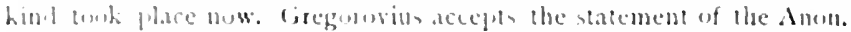

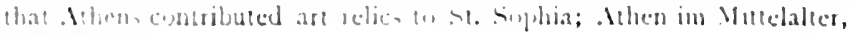
$1,10,1,60$. 


\section{The Building of St. Sophia}

needed to make a brilliant display when placed in position throughout the building. From Carystus came a light green, and from the Phrygian mountains a rose-coloured marble diversified with streaks of deep red and silver. Sparta supplied an emerald green, and the lassian hills a blood-red species veined with a livid white. Much porphyry was floated down the Nile; in Lydia was found a bright-tinted marble seamed with lines of red, and in Numidia a crocusstained variety which shone like gold. Atrax yielded a green and blue marble resembling grass sprinkled with curnflowers; and lastly there was an abundant supply of the coarse white kind in the adjacent Isle of Procomnesus.'

Having cleared and surveyed the site, the architects drew out the plans of the church and fixed the interior measurements at $270 \times 230$ feet. The central portion of this area was to be covered by a dome having a diameter of 107 feet, which should overhang the pavement at a height of I60 feet. No roof of any magnitude, elevated in this manner, was known to them, of which the dome was not upheld by frequent supports, so that free movement from end to end of the building was obstructed by their presence. Anthemius and Isidorus, however, determined that the nave of their church should lic open for its full width in a clear sweep from the main entry to the apse, in which stood the Patriarch's throne." In the central area, therefore, at the

1 These details as to the marbles are drawn from the safe authority of Paul the Silentiary $(617$, et seq.), whose poem descriptive of st. Sophia is copious and exact. Lethaby and S. (op. cit., p. 235 , et seq.) try to identify the marbles as far as they are known to modern commerce.

2 The raising of domes in masonry was well understood throughout the Empire at this time. The knowledge had probably been brought to Rome in the second century E.C. as a result of her conquests in the East. The dome of the I'antheon, built or restored by IIadrian (c. I 20), 


\section{The Age of Iustinian and Theodora.}

comers of a quadrangulat space, they raised fottr piers of massive proportions to uphold an efual number of arches, each of which was to have a span of 100 feet. Blocks of stonc were used for the construction of these piers, and, instead of mortar, melted lead was poured into the inter. stices to knit them more firmly together.' At each comer, the triangular intervals left above the junctions of the arches were filled up with brickwork, and thus were formed four pendentives to sustain the base of the dome: "To resist the thrust of the sreat arches, four lesser ones, two on each side, crossed the aisles of the church to the exfermal walls, which in that position were provided with heary masses of masonry to receive them." liorty windows ranged in it great

measule one lumbed and forty-two fect across, but thi, is a circular hall which supports the dome all round. Anthemins himself, probably, had lately finisloed the church of St. Sergius and hacchus in Itormisdas (now called Little st. Sophia), but in this case eight pillars were given (1) the done, and he was doubtless dissatistied with the effect. Earlier domes in Syria are moticed in Vingue's work. By the use of irom or uteel frame-work, much greater dumes have been erected in modern times than anything known in earlier ages, e.s., Viema Eahihition, $1 \$ 73$, 360 feet. In London we have the Allert IJall amd British . Fuseum (219) and t.q0 feet), the latter a reproduction of the lantheon.

I'rocopius, 10i cil:; l'aulus, 479. According to the Amon., relic of saint and martyrs were deposited in cavitics of the masonry in various places.

the earlient kouwn denne on pendentive is a kennan mansoleum in Palentine of the second century; East. Pal. Mem., 1SS9, P. 172 (1.ethaly and S., ct. ctt., p. 200).

I'rocopius (loce ats) gives some indientions af the difficulties they harl to contemel with throngh tixe fiers threatening to give way, etc. the Anon. rematk that the leme was said to le made of pumice stone, lut that it was in reality of lorich from khosles, me twellth the weight of ordinary bricke. The main theme of Cheisy's work (L'drt de hâtir

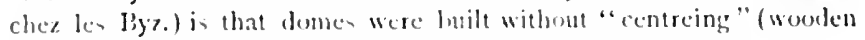
froplenge), iniply ly working in circumferentially till closure. 
circle perforated the base of the dome, which was divided by an equal number of ribs converging from the circumference to its vertex. From the base of the dome the roof was led down by a pair of semi-domes to the east and west walls, and completed on each side by vaulted archings which joined the lateral walls. The nave was separated from the aisles by rows of lofty colunms with sculptured capitals, on which rested a series of arches to support the women's galleries. From them lesser pillars, more numerous, ${ }^{1}$ reached to the roof; and each corner of the nave proceeded by at semicircular sweep to meet the Royal Door and the apse." On the west a narthex ${ }^{3}$ extended all across the church, and above it the galleries became continuous in an area posterior to the nave.' The building was flooded with light from windows which in great number passed through the external walls in every direction.

As soon as the containing structure was completed, the decoration and furniture of the interior was pursued with equal zeal. All vacant surfaces in the lower part of the edi. fice, including the floor, were invested with slabs of marble, showing the greatest diversity of hue and pattern; and the roof was coated with gold mosaic " relieved in prominent positions with coloured figures of a sacred type. A cross appeared at the highest point of the dome, and colossal cherubim

1 One hundred and seven pillars altogether are counted, but only fifty-four are visible as bounding the nave.

2 Technically such corners are called exidras, and their shell-like roofs, conchs. In these corners six pillars stand over two, at the sides over four.

${ }^{3}$ See pp. 55, III.

4 Measured at the level of the galleries, therefore, the length is three hundred feet.

5 I'rocopius, loc cil.; l'aulus, $66 \mathrm{~S}$. 


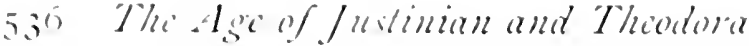

werupied the four pendenteres. Angels at full length were depried in suitable spaces, and the whole was bordered by intricate designs in rarjonsly-tinted mosate. fior the con scerated furniture of the church, the precions metals and gem were repuinitioned at areat cost. The ironostasis, fifty leet wide, which eressed the alpe to shut off the lichol, wats completely encascel in silver. It stout by means of awelie pillats arranged in patirs, back to back. the intervening portions of the sorech heing encrusted with intiges of angets and aprostes with the Jirgin in the centre. 'lhe holy talle was at mass ol gold and precious stonces, and was corered by at ciborium resting on four pillars, the whole being of silfer. silken curtains, richly emblovidered with appropriate designs, hung hetween the pillars. Jeneath the donne was phated atn claborate ambo of unustal dimensions, approathed on the cast and west by flights of stepes. It wats bujle of marble, clevalted on pillars, and enclosed by a rirele of short columns rising from the parement. Comntess hamps surpended by rods and chams from the roof illumbalted the church at night.

Meer live and a half years of haluour St. Sophial was opened "ll Chrismas (537), and made the kecasion of at great popu-

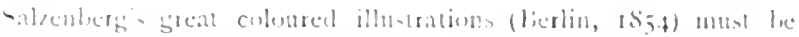

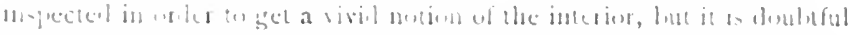

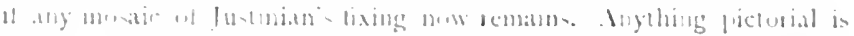

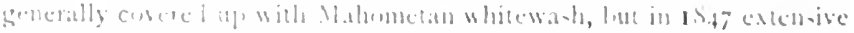

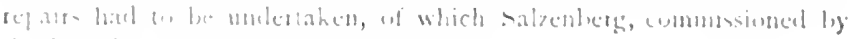

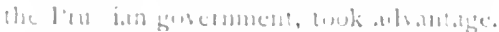

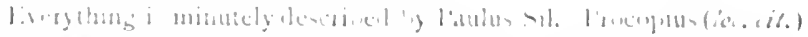

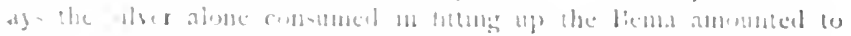

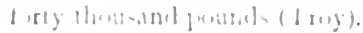

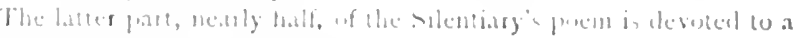

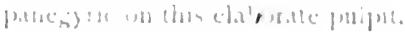

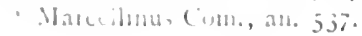




\section{The Building of St. Sophia}

lar festival with a liberal scattering of largess. The Patriarch Menas rode in the royal chariot to the entrance, while the Emperor walked alongside of him among the people.' Filled with enthusiasm, Justinian advanced to the ambo, and, looking around, with his arms extended, exclaimed, "Glory be to God for thinking me worthy to finish such a work; Solomon, I have excelled you!" 2

While her consort was absorbed in the erection of St. Sophia, Theodora interested herself especially in the restoration of the Church of the Holy Apostles, which had become dilapidated through age. A different design was here followed, the form of a cross being given to this edifice, which was surmounted by five domes, one in each of the branches, and a central one at their intersection. ${ }^{3}$ Church building now became one of Justinian's habitual pursuits, and for many years he continued to embellish the Empire with these samples of his religious devotion. In the city and its immediate suburbs, on the Golden Horn and the Bosphorus, new or renovated places of worship continually rose into sight. ${ }^{+}$At Jerusalem a church to the Virgin was constructed with exceptional magnificence, and the numerous religious bodies congregated in that city were handsomely housed by the Imperial exchequer. ${ }^{5}$

The Emperor's contributions to secular architecture were not less noteworthy than his pious foundations. The vestibule of Chalke was restored in a very costly manner as a quadrangular hall, with an imposing roof made up of arches and raults supported on four square columns. This cham-

Theophanes, an. 6030 .

2 Codinus, p. 143 .

${ }^{3}$ Procopius, $o p$. cit., i, 4 . It is almost certain that St. Marli's, Venice, was copied from this church.
"lbid., passim.
5.Ibid., v, 6, 9 . 


\subsection{The Age of Justinian and Theodora}

ber was constituted as a memorial of the wars of Justinian, .nd the walls were corered with scenes of battle and trimmph executed in mosaic. In a prominent position the Imperial comple were depieted as standing among the members of their Court, while the captives and trophies of victory were displayed before them by Bedisarius.' 'The Emperor also commenorated his reign hy raising publir monuments in the capital to himself and his patner on the throne. In the . Augusteum, a pramidal pedestal, rising by steps from a broad base, supported a pillar on which stood an equestrian statue of Justinian in martial costume, holeling in one hand the globe and cross, whilst the other was extended with a warning gesture towards the land of the l'ersians.' On the eastern margin of the city, where the Bosphorus meets the Propontis, Justinian lajd out an esplanade, marble-paved and colonmaded, which be adorncel with a varicty of sculptures wrought hy artists of the period." A splendid pedestal of porphyry, fit to support an empress, occupred the centre, "lpholding a handsome statue which portrayed the "ineffable beauty of 'Theodora, as nearly as a mortal chisel could express it." This figure was a gift from the citisens, in grateful

I'rocopills, of cit., i. ro.

- Mlidl., 2. It was repaired ly Michael VIll, a. 1270: Niccpluorus Gireg. vii, 12 (with uole). Cigllius saw lle lan of it, 2 1550: Tupl. C.l'., ii, 17. An old drawing of the horsemas is reproduced by

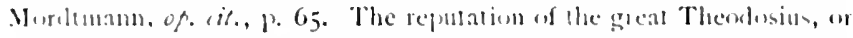
at ledst his statue, was now mbelele, se fustinian demolinfeel it and sel

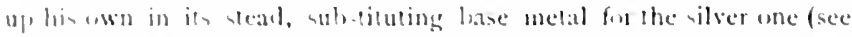

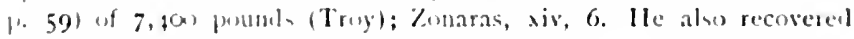

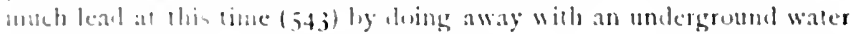
couduil: thil.

If we accept the julgunent of l'recopius, "jou would have tahen

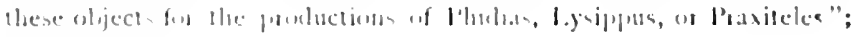
of. 11., 1, 11 . 


\section{The Architectural Work of Justinian 539}

recognition of the construction of this pleasure-resort. ${ }^{1}$ To increase the water storage of the capital, two underground cisterns were excavated on a larger scale than had been attempted by any previous Emperor. The first of these, on the west side of the Hippodrome, was formed beneath the deserted palace of Illus, the notorious rebel in the reign of Zeno, with a roof upborne by $22+$ crudely-fashioned pillars. ${ }^{2}$ The second, of much grander conception, was situated at a short distance to the north, contiguous to the Royal Court of Justice. With 420 columns, whose capitals were sculptured in conformity with the rules of Greek art, this cistern conveyed the impression of a submerged palace rather than of an interior designed to exist in perpetual obscurity. ${ }^{3}$

Justinian was also indefatigable in beautifying provincial towns and in executing such works of public utility as might relieve the inhabitants from any disadvantages of topographical position. In fact, the multiplicity, variety, and magnificence of the buildings which emanated from the constructive zeal of this Emperor induced the chief historian of the period to devote a separate treatise to the enumeration and description of them, an honour which does not seem to have fallen to the lot of any other so-

1 Procopius, of. cit., i, 4.

${ }^{2}$ Jn. Malala, xviii, p. 435; Chron. Paschal., an. 528. The Bin. bir derek ("Thousand-one pillars") long supposed to be the cistern of Philoxenus (See p. 74) is now with more probability recognized as this reservoir. The identification rests on the pillars having heads of the "impost "variety, which is not known to have been in use for long before the sixth century. See Forscheimer, etc., Die byzant. Wasserbehälter, I892; cf. Lethaby and S., of. cit., p. 248.

${ }^{3}$ Procopius, op. cit., i, I I. The Yeri-Batan Serä̈ " Underground Palace") still in existence and full of water ; for details, see Forscheimer, op. cit. Views of both cisterns are given in all modern popular works on $\mathrm{CP}$. 


\section{5 to The Age of Justinian and Theodora}

vereign.' One of fis carliest cares was the aggrandisement of his birthplace, and the hamlet of Tauresium was transformed into the fortified outpost of a flourishing city created by the fiat of its illustrious son. Under the significant title of Justiniana Prima Scupi was clevated to the rank of capital of lllyricum, and endowed hy the Emperor's munilicence with everything requisite to render it worthy of its new importance. A practorium, churches, syuares, porticoe's, baths, and an aqueduct, built with lavish expenditure, illustrated the site; and, to complete its dignity, the archbishopric of the l)iocese was transferred to, or reconstructed in its name. ${ }^{2}$ In the same district he founded a town to perpetuate the memory of his uncle, and called it Justinopolis. He was, however, liberal to excess in the bestowal of his own name or that of his wife on all places indebted to him for restorations or improvements; and abut a score of towns had their identity concealed under the appellation of Justinian, whilst almost half as many found themselves represented as specially "Theodorian."

Among the most important works of Justinian in Asia Ilinor was the protection of towns from river floods, to which the conformation of that country rendered many districts peculiarly liable. To olwiate disasters of this kind ingenious feats of engincering were carried out in several instances. llara, ( ircesium, Edessa, Zenobia, Helenopolis, Juliopolis, and Tarsus, were the worst sufferers in respect of

1 I'rocopius, De dedificii, in six luxks. Fragrius (ii, 1S) mentiens that in Africa alone, after the complest, J. dealt with 150 cities on a more or less exlemsise ecale.

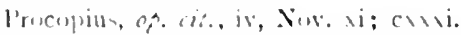

3 See Alemannus, op. at., p. 397 os seg. He has made ant a complete list of every place or thing distinguished liy the nanes of une on other of the rugal patuters. 
their fluviatile vicinage. ${ }^{1}$ By means of walls, cmbankments, dams, cutting away of obstacles, and the provision of emergency channels these towns were secured for the future from damage by inundation. As a specimen of the magnitude of some of these operations the case of Edessa best deserves to be cited. The course of the river Scirtus, as it approached that city, was restrained on one side by a rocky and precipitous bank, whilst a tract of low ground extended for a considerable distance on the other. Hence, in flood time, a vast volume of water rolled over the flat and, entering the town, swept everything away before it. The abolition of this source of destruction was effected by reversing the natural relations of the river banks. Along the shallow margin a wall was built of sufficient strength to resist the overflow, and the rocky boundary opposite was broken away until the ground was made level with the surface of the water. From this side a canal was then cut, which slirted the city and rejoined the Scirtus after its issue from the walls." Bridge building was also undertaken successfully, the most notable examples being that over the Sangaris near Nicomedia, ${ }^{3}$ and one of stone which replaced the old wooden bridge across the Golden Horn.'

Fortification engrossed much of Justinian's attention, and his constructions in that category exceeded, perhaps, in bulk all the rest of his architectural work. The repair and

1 Procopius, op. cil., ii, $3,6,7,8 ; \mathrm{v}, 2,4,5$. The preservation of l'almyra, which seems to have been on the roal to effacement, demanded a great deal of attention; Ihid., ii, I I Malala, p. 425.

$\because$ Procopius, op. cit., ii, 7 .

${ }^{3}$ Ibid., v, 3. The bridge exists, spanning a dry valley, and is figured in Texier's Asie Mineure (copied in Dichl's Justinian).

1 Notitia, Reg. xiv; Chron. Paschal., an. 528. It had twelve arches; Codinus, p. jo, etc.

II. 


\section{$5+2$ The Age of Justinian and Theodora}

rebuilding of walls, the substitution of effective for inadequate mural defences, and the strategical modification of sites, went on continually throughout the Empire. Constantima, the new post of the Duke of Mesopotamia, was raised to the ramk of a first-class fortress,' but the most elaborate works for the purpose of martial defence were executed at l)ara, which still existed as the main bulwark against Persian invasion. The fortilications of Anastasius had been hastily built, and consisted of an uncoursed stone wall, laid without mortar, about fifty feet high. The town was exposed to attack over one stretch of ground only, as in its greatest extent it lay along the edge of a rocky declivity unassailable by an enemy. Instinian consolidated the original wall, closed its battlements so that they became mere loopboles, and raised it thirty feet higher. The towers were similarly treated and elevated until they overtopped the wall to an equal extent. A covered gallery ran through its whole length, from which the soldiers could assail the enemy with their arrows from the numerous loopholes. For still greater security, however, a second wall of smaller climensions than the first, also with towers, but solid, was erected at a short distance in front of the first, and from the top of this rampart the main body of the military were active in repelling an assault. Lastly, a moat was excavated and led along so as to make a crescentic sweep from one end of the atssailable wall to the other." In addition to fortifying cities the Emperor built very numerous forts along the frontiers, and more than six bundred of these are named as being in the vicinity of the Dinube.' Where the configuration of a region

l'renpius, of ill, ii, 5.

- Sirt., 1 (Texier and l'ullan, of. cil., p. 57).

Hit, in, 4, 11. These proiective calstes con isted of a wall about 


\section{The Architectural IVork of Justinian $5+3$}

favoured it, whole provinces were shut off by defensive walls against hostile inroads. This was especially the case at the pass of Thermopylae, the isthmus of Corinth, and the entrance to the Thracian Chersonesus, where existing barriers were now restored to efficiency. ${ }^{1}$ The Long Wall of Anastasius has already been mentioned, ${ }^{2}$ but this bulwark proved less obstructive to the barbarians than had been anticipated, owing to its having been made permeable continuously from end to end. Justinian, therefore, divided it into sections, each of which he separately garrisoned, so that an enemy could not by the capture of one portion obtain the command of the whole, and thus win a free passage into the suburbs of the capital."

seven feet thick and from thirty to forty feet high, to which towers were attached externally of nearly double the height. Most frequently the space enclosed was a quadrangle of about one hundred feet, but might be much larger and of irregular shape. They have been studied mustly in French Africa, where numbers are still found in good preservation. A large portion of Diehl's . Ifrigue by'antine is occupied with a minute description of them, accompaniel by views, plans, etc.

1 Procopius, op. iti., iv, 2, 10.

${ }^{2}$ See pp. 124, 164.

3 l'ucopius, of. it., ir, 9. 


\section{CHIPIER I}

ROME IX THE SIXTH CENTEK: W.K WIH IIE GOH IN ITALY

I the third guarter of the fifth century, the Tcutonic in1 vaders of the Westem limpire had estahlished themselves firmly in all its provinces, and wielded a predominant power in the govermment. In the year 476 Odoracar was the head of the barbarians in Italy, whilst a youth named Romulus dugustulus was formally recognized as Emperor.' The potent barbarian abolished the Imperial throne and relegated its occupant to a decent cxile in the castle of Lucullus in Camprania." At the same time be chepresited the anger of \%eno, the Eastern Emperor, and forwarded the Imperial regalia to Constantinople in token of his sulmission to him ats it riassal."

I few years later Theodoric, the young King of the bast Geths, exercised an ascendancy in Thrace almost equal to that of Odovacar in Italy, and ravaged the country up to the gates of the cappital. Zeno effected an accommodation with him, nominated him as Master of Soldicrs at Court,

Ilalchus, Fixc i, 3.

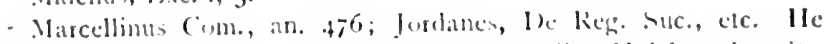

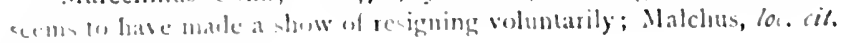

'Aurn. Visle ne, 6 . 


\section{Rome in the Sixth Century}

and even honoured him with the Consulship $(484) .{ }^{i}$ Theodoric, however, was impatient of control; and he proposed to the Emperor that he should march against Odovacar with his countenance, and reign independently in Italy under his suzerainty should he succeed in conquering that country. ${ }^{2}$ Zeno, glad to dispense with his formidable service, at once assented, and the Gothic King departed forthwith on his enterprise (488). ${ }^{3}$ For two years Odovacar opposed the invader in battle, but the fortune of war declared for his adversary; and at last he found himself immured compulsorily within the walls of Ravenna. For three years he held this stronghold against the Gothic King, until the misery caused by the siege rendered him willing to treat. A compact was made that both kings should rule jointly, and Theodoric was allowed to establish himself in the city. ${ }^{+}$Shortly it was whispered that Odovacar was engaged in a plot, a danger which his colleague met by devising another. In this contest the Goth again became the victor. The associate King was invited to a banquet, his movements were hampered under the pretence of calling his attention to a written petition, and Theodoric dealt him a death stroke with his sword $(493)$.

The Goth now secured for himself the allegiance of all the barbarians in Italy, and sent an embassy to apprize Anastasius, who had been raised to the throne in the meantime, of the final success of his enterprise. The new

I Procopius, De Bel. Goth., i. I, etc.

2 Jordanes, De Reb. Get., 57.

${ }_{3}$ Marcellinus Com., an. 4 SS.

+ Procopius, loc. cit.; Cassiodorus, Chron., etc.

5 The only circumstantial account of this affair comes from Jn. Antioch.; Miiller, Frag. Hist. Graec, v, p. 29. 


\section{5+6 The Age of Justinian and Theodora}

Emperor replied with congratulations, and returned to Theodoric the Imperial insignia which had heen sequestered at Constantinople.' 'The reign of the (iothic king lasted for thirty thee years, and was characterized hy heneficence and religious toleration towards his Roman subjects. His court was upheld politically ly the most eminent men of I,atim race whom the West poduced in his time. He retained, as his chef ministers, Bothius and Cassiodorus, men of literary attainments, whose works have come down to ws and are still read for pleasure and instruction. But in his last days the alien king lecame distrusteul of his oficials of native lincage, and Bocthius, with his father-inlaw, Symmachus, fell a virtim to his morbid suspicions.

'Theodoric was suceceded by his grandson . Athalaric, the son of his claughter Amalasuntha, a hoy only teo years of ase. The mother, a beautiful and accomplisbed woman, became queen regent: but she soon incurred the emmity of a powerful section of the (iothic nobles ly erlucating her son arording to the scholastic discipline usual among civilined nations." They insisted that the use of ams was the only lit training for a cothic geuth, asserting that "the hos who bat trembled bencath a rod would never endure

Anon. Vialciii, 6.4.

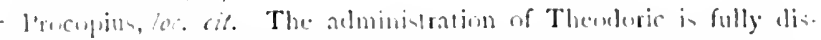

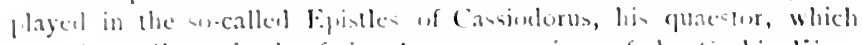

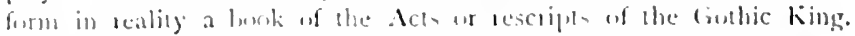
liveything in haly wa mainained accurling w the Imperial yelem

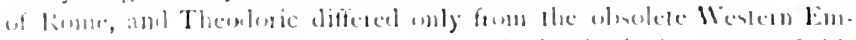

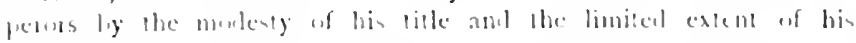
duniniman.

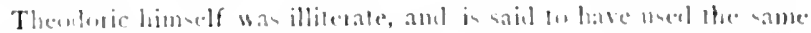

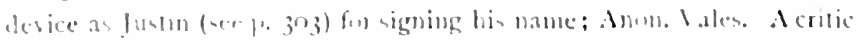

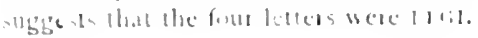


the sight of a sword." As a result his tuition in letters was abandoned, and Athalaric was left free to follow his own devices. If he died in his eighteenth year, after a short career of dissipation and debauchery, we may feel assured that he was incapable of either arms or letters, and the issuc need not be attributed to his emancipation from tutorial control. $^{2}$

Haring despaired of her popularity among the chief men of her nation, Amalasuntha began to nourish treacherous designs against the Goths. While her son was in apparent health she concerted a flight to Constantinople, with the interested connivance of Justinian, contingent on her failure to destroy a faction whom she believed to be seeking her own destruction. When his decease was in prospect she went further, and meditated the total surrender of her kingdom into the hands of the Eastern Emperor. Justinian listened, but the scheme was only remotely feasible, and the Gothic queen made an effort to repair her feminine disability by assuming her cousin Theodahad as her partner on the throne. She offered him the name of King, with the convention that in her alone should be resident the regal prerogative. He accepted, but in bad faith and with a private reservation as to his own prepotency.

Theodahad was a married man of middle age, and has the distinction of being the first recorded scholar of the great German nation whose work in literature and science has so much contributed to the progress of knowledge in modern times. He was a deroted student of Latin and Greek philo-

"For the events narrated henceforward in this chapter, there is generally no source but Procopius (De Bel. Goth., i, ii). Some jottings occur in Marcellinus Com. and Jordanes, but the Liter Pontificalis is indispensable as regards the local Church history. 


\section{5ts The slge of Justinian and Theodora}

sophy, hut he was alien noted for his avarice; and, as the

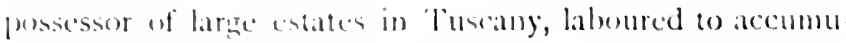
late wealth hy wnflinelang catortion. Frevious to this time Amalasumba had lecen fored to deal sternly with him in order an reporess his unscrupuluus exactions. Exasperated log her interpustion, he also hate contenplated the betrayal of his countrymen: and was at the moment in theaty for the delsery of his provinee on Justinian in return for a position wh homour at the by/antine Court, and a commensurate gilt

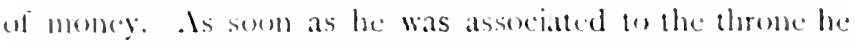
ledgrted with the comemies of Amolastuntha, and made awily with some of here chief supporters. Ilis next stepl wats to seike the person of the pueen, whom he incarecroted in an island castle of the Volsingan late in 'luseans. At the satme time he sent wo legotes, members of the Roman semate, 10 (․ plain the mater a the Emperot. They assured him that the prisener would suffer no persomal injury, and presenterl a letter, written moler constrant by Amalasmotha, in which she spoke resignedly as to here captivity.

Immediately after the sucessful isste of the liundal war fustinian lecance ambitious of adding the kingelem of ltaly an his demingms: and it is probalne that his wishes in this reprect were num. ar less openly expressed. Hence the wertures insidiously made by Amalasumtha and 'Therdabad, whe mut hase read reaty that ang propusals of theirs, which conduced to his cherished design, woulel he welommed ly the bouperen. Justinian wats, therefore, on the watth to find a case for witr, even in occurrences of little moment,

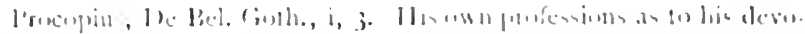

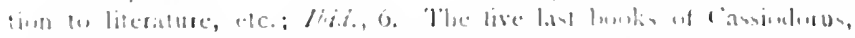

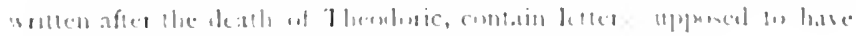

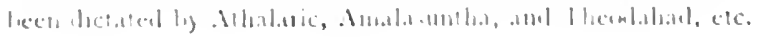




\section{Rome in the Sixth Century}

which would ordinarily be settled by a diplomatic conference. While Grelimer was still a fugitive, a force was sent to occupy Lilibaeum, a fortress at the western cxtremity of Sicily, on the grounds that it had been granted as a depot to the Vandals, on the marriage of Theodoric's sister to one of their kings.' The lady, however, had been imprisoned and ultimately executed by Hilderic, and the Goths had resumed possession of the post." Consequently the proposed Byzantine garrison was refused admittance." lurther, ten Hunnish deserters from the Imperial army had been received in asylum at Naples; and the (ioths, while opposing an inroad of the Gepaeds at Sirmium, had inflicted sonte damage on a neighbouring town of the Empire. The queenregent replied by pointing out the triviality of the complaints, and the shadowy nature of the claim to Lilibaeum; and concluded by maintaining that the Vandal expedition would have been a failure only for the liberal succour she had afforded to it as they lay off sicity. These questions were agitated ostensibly with the view merely of fixing the attention of the Gothic nation; and when the Imperial legates repaired to the court of Ravenna their real mission was to discuss the possibility of annexing Italy to the Empire.' On their return to Constantinople the ambassadors had to communicate, not only the measures concerted with Amalasuntha, but also the proposals of Theodahad, by' whom they had been secretly approached during their stay

1 Procopius, De Rel. Vand., ii, 5.

"Llid., i, 9; Cassiolorus, Var. Ep., ix, 1. She was accused of plotting against the King with her Gothic guards after her hushand's death.

${ }^{3}$ Thid.

'Procopins, De Bel. Goth., i, 3 , whence the naurative continues as beluw. 


\section{The Agc of Justinian and Theodora}

in the Gothic kingdom. Iustinian was overjoyed at the receipt of their message, and began to hope for an carly realization of his project. Without loss of time, therefore, he despatched another legation, more studiously constituted, at the head of whom was Peter Magister. Events, however, had been procecding rippidly in Italy, and they started in isnorance of the death of Althalaric, the elevation of Theodahad, and the deposition of Amalasumtha. In Macedonia they were arrested by the Queen's emissaries, on the coast of Epirus by those of the King: they halted and referred hack to the Emperor. A supplementary instruction was given them; they were to declare in no uncertain tone that Justinian would defend the interests of Amalasuntha.

On his arrival at Raremna Peter found Theodahad beset by a calnal who demanded the death of the ex-pucen as essential to their own and his safety; and, notwithstanding the preponderint presence of the Imperial legate with his special mandate to the point, it was shortly made public that Amalasuntha had been privately executed. Peter denounced the act with velsemenee, and apprized the Emperor, who promptly resolved on war. In the year of his Consulship (535) lielisarius saliled for Sicily with a moderate force, professing, however, that he was on his way to Carthage. Such was the prestige of his mame that the Goths cracuated the island alnost without striking a hlow.' On the last day of the year the Roman gencral entered Syracuse to lay down his Consulship, which he diel with much popular applause and srattering of largess. It the same time Mundus, the master of enddiers in Illyricum, had leen commissioned

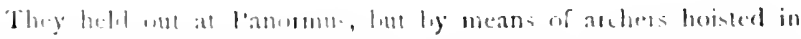

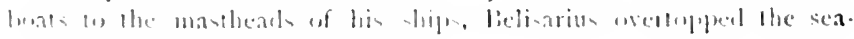
walle, and lenced a yecely -macmber. 


\section{Rome in the Sixth Century}

to attack the enemy in Dalmatia, where he quickly achieved a success by the capture of Salona. Justinian now declared himself openly as the regenerator of Italy against the Arian heretics, who had wrested it by force from the Empire; and he sent letters to the Franks, who were Orthodox, claiming their assistance in his enterprise. The specific permission granted to Theodoric by Zeno, and the ratification of his title by Anastasius were ignored, and the Goths were presented in the same light as the heterogeneous horde of barbarians whom they had displaced. As in the case of Africa the religious sympathies of the native population in this war were on the side of the Byzantines.

Notwithstanding this state of active warfare, Peter had attached himself to Theodahad, seeking an opportunity to extract from him a formal deed of abdication. During these negotiations the Gothic King showed himself to be a vacillating and incapable administrator. He signed a treaty in the most abject terms, reserving to himself merely the name of King, and dismissed the ambassadors. He became fearful, saw himself in the place of Gelimer, recalled them, and tendered a second document, in which his abdication was made absolute; but he imposed an oath on Peter not to reveal it unless his first terms should be rejected. Justinian, however, was soon made aware of the alternative proposals, whereupon he chartered a commission to take over the government of Italy. But in the meantime the Goths had massed their forces in Dalmatia, defeated and killed Mundus, and regained their ascendency in that province. This success effected a reversal in the attitude of Theodahad; he received the Byzantine deputies haughtily, cited historical precedents to show that the person of an ambassador was not always strictly inviolable, and finally 


\section{The Asc of Justinian and Theodora}

committed them to custody on the charge of harbouring treasonalne designs against the head of the State.

The conquest of Italy was now undertaken in carnest, and, while a new general repated the Roman disaster in 1)almatia, Belisarius crossed over to the continent and laid siege to Naples. Having drawn up his flect and army in a threatening position, he called on the citizens to surrender the cown. Collopuies were held hy the townspeople, and, while one party urged that the example of Sicily be followed, unother argued that the vengeance of the foths, to whom the y had given hostages, was more to he dreaded than the attack of Pelisarius. Utimately it was decided to defend the city, and messengers were sent to solicit extrancous aid from Theodahad. More than a fortnight had been consumed in futile assaults and repulses, when the chance observation of an Isaurian soldicr sugsested a means of capture by surprise. While curiously exploring the apueduct he noticed that the water entered the town through a matural mass of solid rock, which had been bored to give it admission. The chanmel, howerer, was ton narrow to allow the passage of an armed man, but would do so readily if slightly enlarged. I few men, therefore, repaired to the place secretly, and, liy dint of working away the stone noisclessly with shap tools, they opened a passigge of sufficient wideh into the city. Under cover of night four humdred select men entered the channel, and followed the course of the appleduct through the town in cquest of a place of exit. The waterway was a valuled gallery roofed with brick, hut at hength they arrived at a point from whence they rould see the sky. ()n each side, however, they were confined hy high walls not casy to scale. Mith some diffienly a man, stripled of his armour, clamberced 


\section{Rome in the Sixth Century'}

up, and noticed a mean house close by, inhabited by a solitary old woman. He reached it by the aid of a tree, which grew alongside, and terrified the occupant into silence. He then attached a rope to the tree, and threw the free end into the aqueduct. One by one the soldiers drew themselves up and descended, till all had arrived safely on the ground. The party then made a sudden onslaught on two towers of the south wall, according to a prearranged plan, slaughtered the guards, and took possession of their posts. In the meantime Belisarius and the army were keeping watch outside, where they strove to monopolize the attention of the garrison by shouting to them continually to capitulate. Suddenly a clangor of trumpets rang out; it was the preconcerted signal, and announced that a portion of the wall was occupied by the surprise party. $\Lambda$ rush with ladders was made to the place, several bands ascended, gates were scized and thrown open, the whole army poured in, and Naples was at the mercy of the Byzantines. On the spur of the moment a massacre was begun, especially by the auxiliary Huns, who burst into houses and captured women and youths, but Belisarius soon succeeded in imposing a check on the inflamed soldiery, and peace was established within the walls before the outrages had time to become general.

The fall of Naples provoked universal indignation among the Goths, and they became filled with resentment against Theodahad. They determined to depose him, and a military conventicle was heid in the vicinity of Rome, where the bulk of their forces were encamped. Vitigis was elected King, a man of no birth, but a general of proved capacity, who had distinguished himself in wars with the outer barbarians under Theodoric. On the receipt of this news 


\section{The Age of Justimian and Thiodora}

Theodahad fled hastily to kavemna, but he was hotly pursucd, on the part of the new monareh, by a Gothic officer, who owed him a private grudge. He was overtaken on the way and remorsclessly slain hy his personal enemy, and thus ended his carcer after a reign which had lasted threc jears $\left(53^{6}\right)$. Vitigis now held a council of war, at which it was resolicel to march northwards in order to effect an accommodation with the Jranks, Venctians, and all external tribes with whom there were disputes, by making liberal concessions in eitch case. The Gothic troops occupied in such regions could then be withdrawn and concentrated into one great arms, with which to return to the south and encounter Belisarius. Rome in the interval was to be entrusted to a small garrison of four thousand men, while the inhabitants were to be reminded that they had always been dealt with liberally by the Goths, and should therefore adhere to them loyally:

These resolutions were acted on, and, while Vitigis retreated northwards, the way was left open for belisarius to march on Rome. 'The liyzantine general lost no time, and his progress through the Cimpania was soon announced. His reputation had preceled him, and the fate of Niples had struck terror into the citizens of the Capital of the Wist. A meeting of the Romans was conrened by the municipality, and, chiefly at the instigation of Pope Silverius, it was decided to submit without resistance to the represemtative of Justinian. Thereupon the (iothic garrison, recognising that their position wats untemable, made up their minds to abandon the city and betake themselses to kavennal. belisarius was met by a deputation which in. vited him to take possession of Rome; and it happeneed that while the Imperial army entered the eity from the south, 


\section{Rome in the Sixth Century' 555}

by the Asinarian gate, that named the Flaminian was being kept open on the north to give egress to the Gothic brigade. The day was the ninth of December, in the year $53^{6}$, and just sixty years since the metropolis had fallen into the hands of the barbarians led by Odovacar. ${ }^{1}$ On this occasion the formality was gone through of sending the keys of the city to the Emperor at Constantinople.

Rome at this time, notwithstanding the vicissitudes it had experienced, had lost, to the superficial eye, but little of its Imperial splendour. A numerous population, amounting probably to more than one million, " still maintained itself in affluence within the ample circuit of walls built two centuries and a half previously by Aurelian. ${ }^{3}$ The construction of those walls had been necessitated by the expansion the city had undergone since the age of the Republic and the first emperors. Fourteen principal gates provided for communication with the surrounding country, and an equal number of lofty aqueducts, in many situations architecturally decorative and imposing, supplied water to the interior from various outlying districts within a circumference extending to sixty miles." The transformation of Rome from a city of dingy and tasteless aspect, which had arisen on the borderland of civilization, to a handsome capital adorned by all

1 Procopius, De bel. Guth., i, I. .

2 C. 400 Rome contained I,797 palaces of nubles, etc., and 46,202 insulae; Notitia Occid. Including slaves, the first would account for at least 100,000 inhabitants, and the latter (large apartment houses) for something like $2,000,000$. This is about the best basis for suessing at the population.

3 IIist. August., 21, 39.

${ }^{ \pm}$Procopius, De Bel. Goth., i, 19; Cassiodorus, Tar. Ep., vii, 6. The Porta Maggiore and the so-called Arch of Drusus belonged to aqueducts. 


\section{The Ase of Iustinian and Theodora}

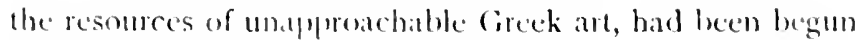
and almost accomplished by Augustus.' 'The pride and magniliecnee of his unceessors, in their spirit of alssolutism and self-adulation, had continued his work livishly until the seven hills, with their disjunctive villeys, were hidden heneath a lahyrinth of sculptured stone and mathle:- - pillared temples and palaces, great halls upheld by endless ranges of ormate columns, continuous porticoes, colonnaded squares oecupied hy lofty higured momum.nts and legyptian obelister public baths of immense area decorated inside with fresco and mosalic, theatres and circuses on a vast scale, stupendous trimmphat arches spanning the main thoroughfares at frequent inturvats, splendid fountains, a crowd of statues almost equalling in mumber the people to be secon moving along the streets, and, lastly, coen sepulchres of a magnitude and elaboration not surpassed by edilices intended for a conconrse of the livings. In their private sphere the grealt noliles emulated the work of the cmperors, and construted such extensive and rostly dwellings that they were compared to reprodetions in miniature of the city without. beyond the walls the surburban areat was so thickly populated as sarcely to be distinguished from

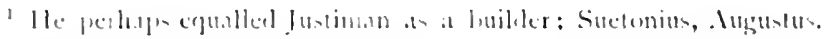
Suc the Yout. Ancyl. for it list.

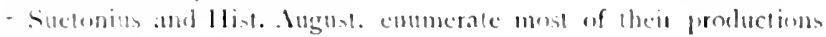
in mastilly:

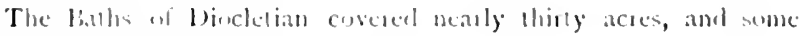
whern were alosest as lange.

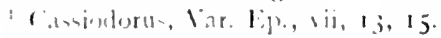

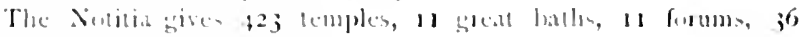

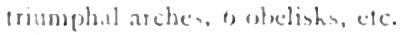

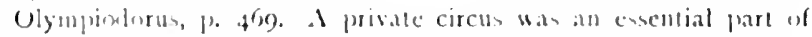

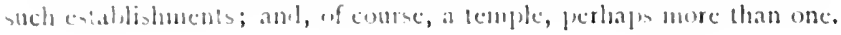


the fortified enclosure. In vain had Constantine striven to create a new Rome on the Bosphorus which should rival in grandeur the historic capital; to the last a native of Constantinople would be struck with wonder and admiration on beholding the city of the Tiber. ${ }^{1}$ From some elevated post, such as the Capitol, crowned with its massive temples, an observer might comprehend in a glance some of the main features of the world-subduing metropolis. His eye would be riveted in succession by the huge bulk of the Coliseum, girded with pillars and statues rising in four tiers to a height of one hundred and sixty feet; by the tall embossed columns of Trajan and Antonine projecting above their respective peristyles; by the expansive dome of the Pantheon sheathed with bronze tiles; by the Mausoleum of Hadrian, a commanding pile on the river side, also encircled by superimposed rows of pillars and statues; and by the tomb of Augustus, a lofty mound ascending from a cylindrical base by a slope planted with evergreen trees, and surmounted by a colossus of that emperor." Tet were a Roman, who had lived in the age of the Caesars, to revisit the capital in the sixth century, he would be struck by some remarkable changes. Traces of the religious rerolution which had culminated in the fourth century were everywhere apparent; Paganism effete, and Christianity bursting into bloom. Deserted temples, neglected and often verging to dilapidation, their columns tottering and sometimes fallen to the ground, offended the artistic sense. On the other hand Christian basilicas had sprung up, and

1 As in the case of Constantius II on his visit to Rnme in 356 ; Ammianus, xvi, ro.

2 Sirabo, 1 , iii, 8 . The ring of wall which formed the base still exists, and has recently been used as a circus.

11.

OO 


\section{$55^{8}$ The Age of Justinian and Theodora}

in some localities were great and conspicuous objects. below the Coelian hill the Lateran gardens were occupied by the Constantinean Cathedral of the saviour: and the original hasilica of St. l'eter had taken possession of the Vatican mount. Without the walls, on the south, the great church of St. Paul had been huilt to supply the religious meeds of the teeming population of the suburbs.'

An observant historian, resident in the West during the latter part of the fourth century, has left us a striking picture of Roman socicty in his time, which, with essential modifications, may be applied to illustrate the manners of the Italian eapital under the rule of 'Theodoric. The national aspirations and energies of the Roman people, having heen nurtured and gratified progressively by success during several centuries, arrived at the stage of inflorescence in the preAugustan age. The long-continucd training and encouragement of intellectual activity was then producing those fruits which are characteristic of the highest degree of material prosperity: men experienced in war, habitual conquerors ambitious to rule; accumulations of wealth in the hands of numerous private persons; and a lively interest in literature and art. Hence sprang civil wars ending in despotism, boundless luxury, and new creations in the realm of poetry, history, painting, and sculpture. litt the outcome of the autoracy was a cessation of mental activity, emulation became extinet, and a perind of stagnation set in, lending gradually towards settled apathy and indifference to all purposive effort. Dhout two centuries after the founclation of

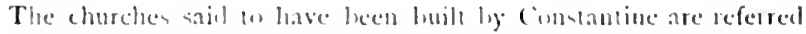

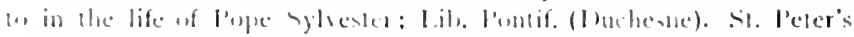

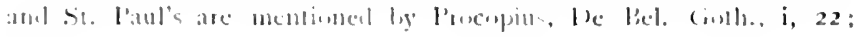
i1, 4. cic. 


\section{Rome in the Sixth Contury}

the Empire these results began to be fully apparent, and an aimless abandonment to pleasure became the distinctive mark of the age. Thus arose the sociological phenomena which at the end of the fourth century have been recorded by the historian of the period. The nobles revelled in the enjoyment of their great wealth; the lower orders became seditious unless they were provided with sustenance and amusement without having to earn them by work. The rich devoted their time to receptions at which they were waited on by a crowd of interested flatterers eager to win substantial proofs of their farour. They nerer tired of boasting to their audience of the extent of their possessions and the revenue they derived from them.' Through lack of any legitimate occupation their dormant energies could find no outlet except by taking an overwhelming interest in the routine of petty acts necessitated daily by physical existence. Meal-times, most of all, absorbed their attention; a multitude of servants stood around, and the introduction of every dish was an event of grave importance. Fish, birds, and dormice were the chief constituents of their fare; and as each cooked animal was placed on the table it was subjected to the keenest observation. Should anything excessive in the way of size or plunpness be apparent, all present ejaculated their admiration. A weighing-machine was sent for in order to ascertain how much it would scale, and a secretary brought a book in which to register the particulars of the astounding occurrence." The intervals between their repasts were given over to gambling, less frequently to music, and on rare occasions to reading. A game of skill with dice was the favourite pastime, and one who had mastered all the 


\section{The Age of Imstinian and Theodorer}

shifis and trickeries of this diversion, even though of hase origin, receised universal homage as a man of emincence and dintinction.' Musicians were often entertained with honour in rieh houses, singers heing in great repuest, as well as performers on the hydrutic organ or the lyre, which had been increased to such a size as to exceed the modern harp." The era of light fietion had not begum, hut some solace wats found in perusing the satires of furenal, who attracted by his inderencies in spite of his cthics, and the compositions of Marius Maximus, the author of copious and scandalous biographice of the (acesars." In their excursions out of doors both men and women of the wealthy classes assumed the pomp of a royal progress. 'The noble occupant of an ormate gilded coach was attended hy stewards who marshalled all the servile menthers of the household in a kengthy procession. First came the handsome and linely-dressed slares addicted to light employments: then a grimy crew of those who were busied about the kitchen: and lastly a company of eunuchs in two bands, those in from lecing old men with wrinkled and distorted features, and lechind a troop of boy. castrates who were prized for their fresh appearance" ('ostly" apporel was the special extravagance of a certain class: and when walking they displayed themselses elat in layer upon layer of fine mantles, held at the neck only hy a jewelled (latpl, so that the loose folets constintly nying open might whibit their variegated embroideries picturing the forms of

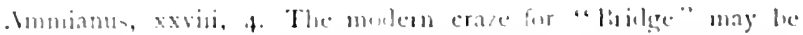

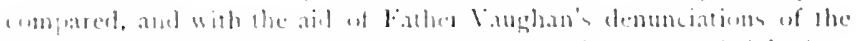

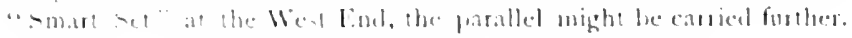

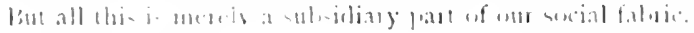

- Miri., is, a.

livit., Wia, .1.

+ Helt, ul, e 


\section{Rome in the Sixtle Century' $56 \mathrm{I}$}

different animals.' While such men would pass an ordinary citizen without notice or with a supercilious glance of recognition, a noted courtesan would be greeted with effusive compliments and caressed with flatteries as if she were Semiramis or Cleopatra." No section of the community was more estecmed than the dancing-girls, and of these three thousand were constantly figuring on the boards of the theatres. On one occasion, when a dearth of provisions seemed imminent, and foreigners, including many professors of the liberal arts, were suddenly expelled from the city, the question of dismissing these sylphs, together with their trainers and slaves, in number much greater than themselves, was never once brought up for consideration." In such a state of intellectual torpor the slightest journey was regarded as an enterprise demanding extraordinary fortitude; and if a noble paid a visit to his provincial estates or undertook a short voyage in a painted pleasure-boat to the watering places of Baiae or Cajeta, he afterwards extolled his achievement as if he had performed something worthy of Alexander or Caesar." Is for their religion, although they scoffed at every formal belief, they were earnest votaries of magic, and apprenticed slaves to professed sorcerers in order to encompass the art of injuring or influencing other persons by means of mystical operations." Nor were they willing to arrange their meal-times, their baths, or their appearances in public, without consulting an almanac with the view of ascertaining the station of Mercury or the posi-

Ammianus, xis, 6. Garments of this pictorial class were of course common to the whole Empire, and were inveighed against in the East about the same time by Asterius, Hom. I (Migne, S. G., xl, I65).
2 Ibid., xxviii, 4 .
${ }^{3}$ Ibid., xiv, 6.
"Ibill., xxviii, 4 .
"Ibid., xxvi, 3 ; xxviii, I. 


\section{The Ase of Justinian and Thoodora}

tion of the moon ameng the constedlations.' In the reign of Valentinian I an epidennic of poisoning hecame rife, and all inconsenient relatives were got rid of by the administration of deleterious drugs." "lhese exeesses were rigorously repressed loy that irascible emperor, who even executed some men of senatorial rank for being concerned in magical practices." At the same time adultery and seduction were dealt with by capital punishment, and both men and women of noble rank perished for these crimes. As for the common people, they were indolent and dissolute, spent their time in wine-shops and brothels, were addicted to gambling, and in their lower sphere imitated the pride of their masters by pretending to high-sounding names and descent from illustrious families, even though withont shoes to their fect. Their devotion to the games of the Circus was as intense as that of the Constantinopolitans, but the factions of the Blues and Greens were not of such political weight or such breeders of riot as their fellows of the Byzantine capital. But the Roman populace were more expectunt of public gratifications in the way of amusements, largess, and bread, and broke into violent seditions when there was any prospect of their being limited or witheld. If the com-fleed were delayed their animosity was directed against the l'raefect of the City; if the public spectackes were parsimoniously provided for, agrainst the l'ractor of the (iames: and, unless those officials found means to assuage the tumult, their

. Immiants, sxviii, 4 .

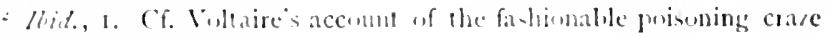

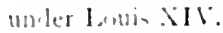

Ammianus, sui, 3 ; ssuii, 1. 'Jlit.

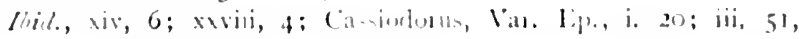
etc. 
houses were liable to be attacked and burnt by an infuriated mob. ${ }^{1}$

Such was Rome at the beginning of the fifth century. Secluded in the heart of Italy, her tranquillity had never been disturbed by the commotions which the turbulent barbarians were for ever exciting on the distant frontiers. But in 4 ro the Visigoths raided Italy, and Alaric forced Rome to capitulate. Forty-five years later the city succumbed to Genseric, but in these cases, beyond the abstraction of a large amount of treasure, it does not appear that any material damage was inflicted. At the nominal fall of the Western Empire the capital was peacefully transferred to Odovacar, and under Theodoric the Senate was maintained in its privileges, ${ }^{2}$ whilst the municipal officers continued to be selected and appointed with studious regularity. ${ }^{3}$ Repairs of the walls and public buildings were executed systematically, ${ }^{\prime}$ and the Circus was kept up as formerly under governmental supervision." But Roman pride must have been sullied by the frequent submissions to barbarian hosts; and the settlement of the intruders all over Italy on private estates must have reduced the affluence of the nobles to moderate proportions. The glowing picture of Roman life, as it comes from the hand of the fourth-century historian, must therefore be received with large abatement before it

1 Ammianus, xix, Io; xxvii, 3.

- Cassiodorus, Var. Ep., i, I3, 27, 42; iii, I 2; v, 4I, etc.

${ }^{3}$ Ilid., vii. This book consists of forms of instruction to newly appointed officers, from Consuls and Praetorian Praefects downwards.

I Ibid., i, 25, 2S; iii, 3I, etc. Procopius (De Bel. Goth., iv, 22) remarks that the Romans were proud of their buikdings and took great care of them.

Ilid., i, 20; iii, 51, etc. 


\section{$56+$ The Age of Justinian and Theodora}

an be accepted as delineating society in the capital as it was when entered hy the Byzantines.

After the departure of Vitigis, Bedisarius semt his lieutemants bessas and Comnantine into Puscany to test the attitude of the inhabitants, and they som had the good fortume to receive several submissions, among them the towns of Varmia. Permsia, and Spoleto. During this period he himself was busy in repairing the walls and replenishing the granaries of Rome. In the meantime the fothe king hat estahlished himself at the court of Ravenna, where he took actire measures to consolidate the aftairs of his nation. The Franks, who had already given pledges to lustinian, were won over to a secret alliance hy the cession of Gallia: and he repaired his defect of hirth by coereing Matasuentha, a maiden in her teens, the daughter of the late queen, into a hasty marriage with him. He now infused all his energies into the war, and, having despatched a flet with reinforcements to l)almatia, marched on Rome at the head of one hundred and fifty thousand men. As the forces under Belisarius were reported not to exceed a tithe of that number, he arlianced with great confidence, his only fear being that hefore his arrival the Byzantine general should have saved himself by flight. While he was on his way, Bessas and Constantine, at the call of their chief, returned to Rome with their brigates, having left a small garrison in circh of the raptured towns.

The first collision with the enemy was brought about by Belisarins himstelf, who went out to recomnoitre their approarh accompranied hy a thousand horse. Ilang blocked

A mall part of sombern frunce, memlern l'rosence.

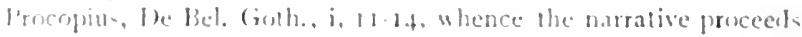
a. $\mid, \ldots\}_{1}, w$. 


\section{War with the Goths in Italy' $\quad 565$}

the Milvian bridge over the Tiber, a mile and a half to the north of the city, with a tower, he expected that Vitigis would be delayed for sone dily before he could improvise means for crossing the river. But the guards of the tower fled at the first sight of the enemy, who at once broke through and poured into the plain. Hence before he could effect a retreat he found himself confronted by their cavalry in force, and a desperate encounter immediately ensued. Mounted on a dark charger dashed with white over the forehead, the Master of Soldiers, more admirable than prudent in his conduct, threw himself into the fight with the utmost ardour. The horse, trained for the battle-field, shared his rider's zeal. Belisarius was soon recognized by some deserters, and the word ran through the Gothic ranks that the fortunes of the war were identified with the most conspicuous combatant. He at once became the central mark for javelins and spears, while the bravest of the Goths rode to the spot, eager to fell him with their swords. With untiring energy, wielding his sword, now on this side, now on that, he struck down all who came within reach of his arm, while his guards, with irresistible bravery, closed around him and repelled the assailants. At length their unyielding determination won the victory; the Goths broke and fled to their camp, leaving nearly a thousand of their number on the field. The Romans pursued them, but were soon driven back by a mass of infantry, and with difficulty regained the walls of the city. 'There they clamoured loudly for admittance, but those within were afraid to open the gates lest the enemy should enter along with the fugitive band. It

was now nightfall, and the hero of the day, who was reported fallen, was unrecognizable in the dusky air under a coating of blood and dust. Belisarius now rallied his men, 


\section{560 The Ase of Justimian and Theodura}

and they turned with a great shout against the attateking party, who thus received the impression that reinforcements had issued from the city and beat a hasty retreat. 'They were permitted to depart unmolested, and then, the gates being openeel, all were cuabled to reach their guarters in safely. Notwithstanding his titanic exertions liclisarius had escialed without a wound.

both sides now matured their dispositions for pressing on and sustaining the siege. Belisarius posted divisions of the sarricon at each gate, drafting into the service all the available citiens, and walled up the appeducts at their place of entry, lest the enemy should be tempted to imitate his own successful stratagem at Naples. It the same timse he exhorled the townspeople, who were inclined to jeer at his cemerity in defying such a huge army, to be of good cheer, as he had excellent reasons for predicting that he should be victorious over the Goths. On his side Vitigis disposed his forces in seren fortified camps on the north of Rome, one being across the river near St. leter's by the Vatican. In cach case he dug a foss and cast a rampart, the top of which was defended by a line of stakes. livery channel by which provisions could enter the city was blocked, and all the appeducts were cut through in order to produce a water famine. A variety of machines for storming the fortifications were also constructed: battering rams; Wooden towers as high as the battlements, rolling on four wheces and drawn by oxen: ladders in great number: and bundles of sticks and reeds to fill tip the moat and thus give access over level ground to the walls. To resist such attacks engines for throwing heatry stomes and durts were placed on the top of the walls by the besieged; huge beams, provided with leeth and worked by ropes, were hinged to the galles so ats to beat 
down the enemy if they attempted to force the portals; and the towers were brought to a standstill by killing the draughtoxen with arrows.

During the first few weeks of the siege many determined efforts to scale the walls were made by the Goths, who expected to overwhelm the small garrison by their superior numbers. The most notable of these attacks was that made on the Aurelian gate, which stood on the river bank and was connected by a bridge over the Tiber with the quadrangular base of the Mausoleum of Hadrian. Constantine, with a small detachment of the garrison, occupied the walls and the monument, from which a colonnade extended to the church of St. Peter. Under cover of the portico the Goths were able to advance to close quarters without fear of missiles shot by hand or from the engines. They emerged from beneath in great force, protecting themselves with large shields and carrying numerous ladders. Some strove to ascend the monument; others crossed the bridge to scale the city walls. As soon as they appeared in the open their attack was hotly contested by the Byzantines, who aimed at them with arrows and stones from the engines. By a sudden impulse, those who defended the Mausoleum seized on the statues with which it was decorated, broke them in pieces, and hurled the fragments with both hands on the heads of the assailants. Thus for some time the battle raged furiously, but at length the Goths were repulsed.

As the siege proceeded, weekly sallies from the gates were studiously organized by Belisarius; and in these encounters the Goths almost invariably suffered in extraordinary disproportion to what might be expected from the paucity of combatants arrajed against them. On one occasion, for example, in a battle at the Salarian gate, thirty 


\section{The Ase of Juslinian and Thodora}

thousund of them are stated ho hare leen slain, while the wounded totalled a still lareer amount. Having ly such result proved his forecast that victory would incline to his side, belismius combescended to explain to his staff why he had expressed himself sorenfidently at the begimming of the siege. 'The byantime amy, he pointed out, was composed almont entirely of atilful horse-archers, especially the Ilums, whils the (iothic caraly were provided only with swords and spears, heins, momeoser, withent protective armour. Jonre, they were powerless execpt in a hand-to-band hight; but in contlict with bis mounted bowmen most of them were brought down before they could come to chese guaterters. surh wat his demonstration, hut mevertheless, as wecks rolled orer, the Roman general found that his position was becoming precarious owing to the diminutive size of his army and the immonse host which they had to resist. 'The Goths also, talught by experience, ceased to attack the walls in a densely parked throng, a proceeding which was the prime callse of their being repulsed with such buge shanghter, since every missile amed at them told with deadly effect. He legan to fear, therefore, that in the end his task might prove to be greater that he could cope with, and set about devising expedients to lighten the situation. In one waly the lneicired were not so bard pressied as might hase heen antici. frated: whing to the extensive eircuit of the walls, even the very mumerous forces of the (ioths were unable (1) maintain a seriet herkade. Thus emmonication with the outside worlal, thesgh not devoid of risk, Was still facile. lindisatus

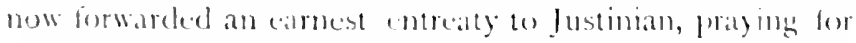
winfurecurents, and representing that the hardslips endured by the Romans might indere at remewal of their allegiance to the cinths. He also determined to cmoty the eity of all 


\section{War with the Goths in Italy}

inhabitants who were useless for its defence: and this was done one night after the enemy had returned to their camp. An immense multitude--women, children, and slaves-were cast adrift, and some by boats down the Tiber, others on foot along the Appian Way, fled to the south, ultimately finding a refuge in Campania or Sicily. For a different reason Pope Silverius and several senators were dismissed, as suspicions were aroused that they had begun to treat clandestinely with the Goths.

After this departure, however, the horrors of the siege began to be felt more acutely on both sides. Vitigis, secing that his efforts were being frustrated, stationed a body of troops at the mouth of the Tiber to prevent supplies reaching the city by water; and he also transformed some of the arches of each aqueduct into guard-houses so that they might intercept the import of provisions from the surrounding country. Inside Rome the agitation grew to an extreme, and, as famine and pestilence became rife, a recrudescence of Pagan superstition began to be manifested. In the night some eager hands essayed to open the temple of Janus in the Forum, but the brazen doors, long rusted upon their hinges, refused to turn; and a gaping at their junction was all that attracted notice next day to indicate the ineffectual attempt. At the same time, all who were fit to bear arms clamoured to be led out against the Goths. Soon, however, fresh forces began to arrive from Constantinople, and a regiment of fifteen hundred succeeded in entering the city. Later on, a fleet manned by three thousand Isaurians reached Ostia and hovered about the river mouth to convoy provision ships which were preparing to run the blockade. Procopius and Antonina had, in fact, been sent to Naples to organize relief measures, and they returned before long with 


\section{The Age of Justinim and Theodora}

copious stores. I number of small boats navigated the liber and revictualled Rome unopposed, although observed by the Goths, either because they had become apathetic, or because orertures for peace had already been made hy their King.

The siege had commenced in March, and such was the progress of events diming the succeding nine months. When December had already leen entered upon, Vitigis found that his position was becoming desperate, whilst the capture of Rome seemed more hopeless than ever. In almost culless succession of defeats, together with discase and deficiency of food in his ampl, had been productive of chormous losses to the Gothic army; and it was now rumoured that both hy land and sea a sreat increment of forces was on the way from Constantinople. He resolved, therefore, to make peace with the Empire, if any reasonable lerms conld be obtained from his atdersaries. A conference in Rome hetween three (iothic delegates and the Master of soldiers was the result of his decision. With the tone adopted by the Byzantine Court at the beginning of the war rankling in their mind, the representatives of Vitigis recapitulated the story of Odovacar, Theodoric, and the Emperor Zeno; and thence inferred the injustice of the present invasion of Italy. founding his arguments on the most arrogant pretence or ignorance, liclisarius, in reply, asserted virtually that Theodenic had leen merely an general employed by Zeno to restore It.ly to his dominions, and charged him roundly with perfidy and ingratitude for setting himself up on an indefendent throne in that comntry. In the face of such insolent or ignorant assurance, expostulation was evidently futile, and the foths combl only proced to mention hesitatingly their hid for peace. 'They would cecte Sicily, Campania, and 
Naples, and would pay a yearly tribute to the Emperor. $\mathrm{He}$ thanked them ironically for their generosity; they would give away what was no longer theirs; Britain in return should be presented to the Goths; a much finer island than Sicily; it had once belonged to the Romans. "At least," they urged, "let us communicate with the Emperor, and let there be a truce for three months until we receive his answer." To this proposal he gave a careless acquiescence, and the deputation then withdrew.

Belisarius, however, had no intention of not pushing his advantage in arms. Reinforcements had been arriving in batches, whilst the enemy had relaxed their vigilance in the belief that hostilities had practically ceased. Finding himself, therefore, with a surplus of troops at Rome, he began to throw detachments into erery town of the neighbourhood, which was not in a state of active defence. At the same time he ordered John, a nephew of Vitalian, to proceed northwards with two thousand horse, cautioning him in a tone of levity not to begin raiding the country at once, but to await instructions. Seeing that the attitude of the Roman general amounted to no more than a farcical observance of the truce, Vitigis, on his side, began to ponder over some insidious stratagem by which he might capture Rome. First, he attempted a nocturnal entry through a subterranean aqueduct; but after exploring its channel for some distance into the city, his men were brought up by the recent obstructions and had to retreat. Then he bribed some of the purveyors of wine to the garrison to ply the sentinels on the river wall, where they were fewest in number, with drugged liquor, but one of his intended agents betrayed the plot. He even tried to rush the walls at the Pincian gate by a sudden onset with ladders and fire during the dinner 


\section{The Ase of Justinian and Theodora}

hour, but the approach of the surprise party ias signalled, so that they were met and repulsed.

Through the (ioths being seduced into these attempts by his own enterprises, Belisarius found the opportunity be was looking for, and paid no further heed to the fartitious truce. He now, therefore, gave the expected cue to fohn, who at once lagan to devastate rentral Italy, in a chase from Amsinmm to Lrbinum, and shortly arrived within sight of Ariminum on the Alriatic. Ilere was another traitress, ready (o) betray her nation for the sake of personal piepe and vexation; and fohn soon received a message from Matasucutha, the unwilling wife of the (iothic king, proposing that the eity should be surrendered to him with her collusion. This trachery was quickly consummated, and the lientenantgencral took possession of that important stronghold.'

As had been foresecn, consternation spread through the Guthic camp before Rome the moment the news arrived that their families and homesteads to the north were heing lented by the Ijyzantines: and Vitigis, himseli in great concern at the malevolence of his wife, decided at once to raise the siege. Iith the least delay persible the barbarian host, having fired their encampment, put themselves in motion and marched nothwards on their return to kavenna. The unusmal wetivity was soon ohserved by the Romans, where

I forgen fo mention that when liclisarius wal merely on his way to Naple, libimuth, the sn in law of Thedahad, came oser to the ligzan.

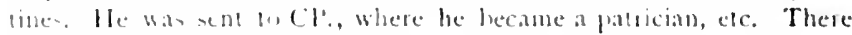
were wher unnecenary trathere of allegiance, showing that many of the cothe were incapalite of remaning true w themelves. In general.

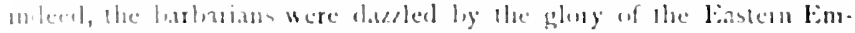

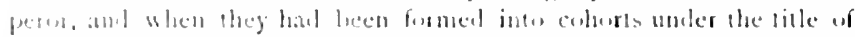

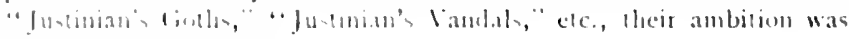
gratitient the the ntment. 


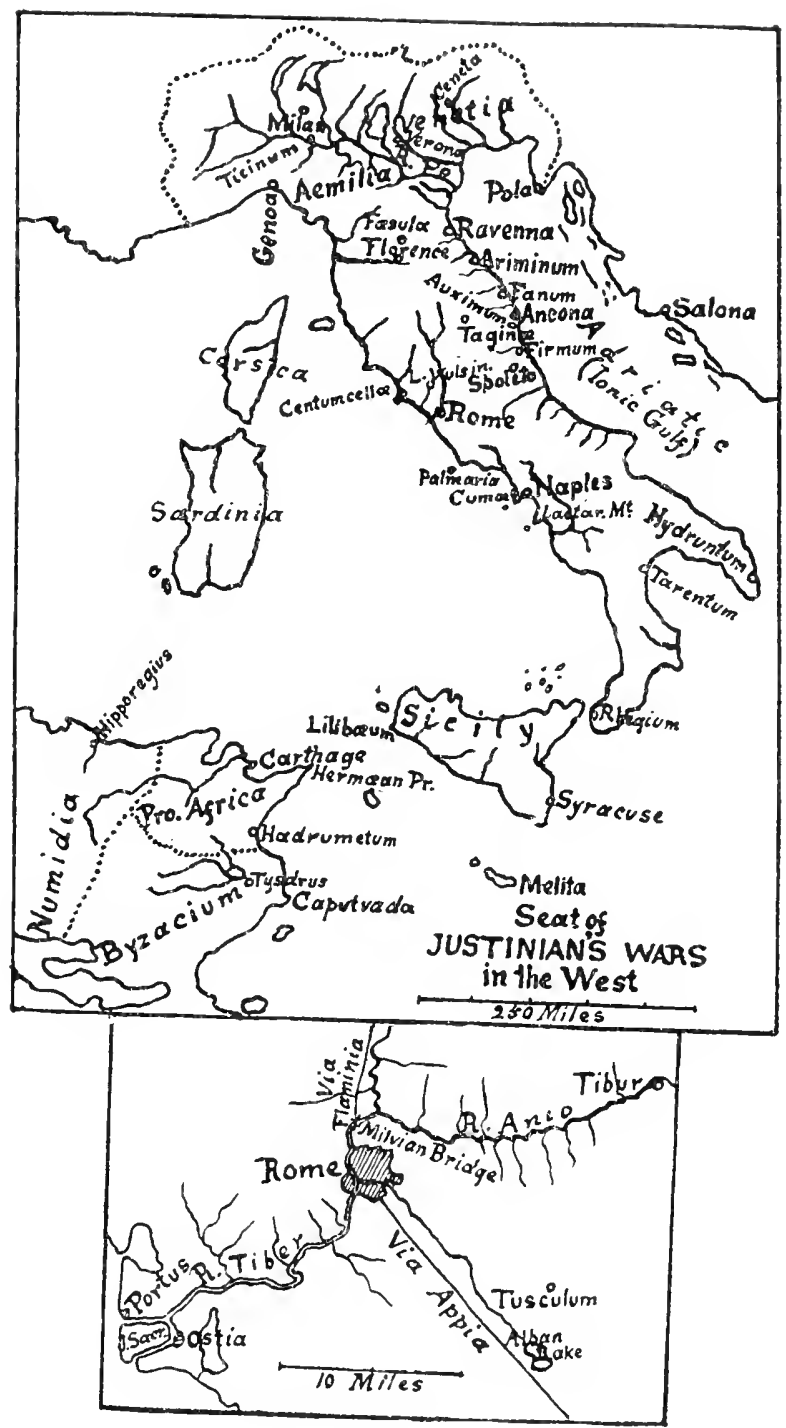





\section{War with the Goths in Italy}

upon Belisarius discharged all his available forces through the Pincian gate to assault the retreating enemy. A sharply contested battle ensued, but the Goths shortly took to flight and made all haste to cross the Milvian bridge. There the crush became excessive, with the result that numbers were drowned in their armour as they attempted the narrow passage, whilst those in the rear were falling under the weapons of their adversaries. Thus ended the siege, having lasted for one year and nine days, during which time sixty-nine battles were fought between the besieged and the besiegers.

Belisarius was now free to undertake the conquest of central and northern Italy, and the next eighteen months were occupied by his efforts in that direction. While he was still pent up within the walls of Rome the Bishop of Milan and several of the chief citizens had waited on him with a request that he would send a small garrison to take possession of their city, and relieve them from the dominion of the Goths. One of his first cares was to act in accordance with their suggestion; and thus the greatest city of the West, after Rome, surrendered voluntarily to the Byzantines. Subsequently many other fortified towns, including Ancona, Urbinum, Faesulae, Civita Vecchia and Auximum were captured or submitted as a matter of choice. The Goths, on their side, were continually active and not always without success; but they failed in their efforts to recapture Ariminum, the beleaguering force having fled precipitately at the simultaneous appearance of Belisarius on land and of a Roman fleet in the bay. Throughout this war the Romans had the command of the sea, sometimes with much inconvenience to the Goths, who were thus liable to have their supplies cut off, but no naval battle was fought.

One of the most notable occurrences of this year $\left(53^{8}\right)$ II. 


\section{7t The Age of Justinian and Thoodora}

was the advent into Italy of Narses, Count of the Sacred Lareseses, with a command of seven thousand men. The lliustrious rank of this official, and his briliant position at Court, seemed to unfit him for a subordinate post: and immediately on his arrival doubts arose in the minds of many as to whether he should not be regarded as the commanderin-chief. Although a eumuch, he had proved himself to be a man of exceptional energy, and had won a reputation for sagacity which placed him in the forcmost rank among the statesmen of his time. The two leaders met at lirmum, and Narses at once adopted an attitude of independence by pronouncing an opinion which was in conflict with thit of the Master of soldiers on a vital question. Ariminum was hard-pressed by the enemy, and appeals had been sent out for succour. But the intervening country was held in force by the Goths, and Belisarius thought a march to the place too risky to be undertaken. In addition, his scheme for the defence of the town had been mullified by John's refusal to follow his instructions, and he was inclined to mark his sense of the infraction of discipline by leaving him to his own resources. But the eunuch pointed out that the loss of such an important stronghold, defended by a general of the first rank, might be an irreparable blow to the lmperial prestige, whilst it might be considered that John had been sufficiently. punished by having heen reduced to such a strait. liclisarius yielded, and the town was relieved suceessfully, as stated abore; lut John, on his release, declined to express any thanks to his chief, declaring that to Narses only was his gratitude due. After this incident the army was split into two factions, one of which alhered to belisarius, whilst the others ranged themselves around Narses. Being anxious for unity, the former comvoled a mecting of the staff, and, 


\section{War with the Goths in Italy'}

having presented his plan of campaign, called upon the eunuch to second his efforts with loyal consistency. Narses, however, dissented from his views, and expressed his intention of leading the forces which were at his disposal to a different part of the country. Thereupon Belisarius produced a rescript from the Emperor, in which all were enjoined to obey him as sole commander-in-chief, whilst Narses was excluded by a special clause from having any claim to exercise such authority. Nevertheless the dissident party, distorting a formal expression of the rescript by a verbal quibble into permission to do as they liked, seceded from the Master of Soldiers, and decamped with the $1 \mathrm{~m}$ perial treasurer to wage war according to their own judgment in the province of Aemilia.'

The greatest calamity which befell Italy during this war was the recapture of Milan by the Goths, a disaster which appeared to be a direct result of the counsels of Belisarius having been rendered inoperative by Narses. As soon as the dedition of that city was anncunced to Vitigis, he detached one of his generals to beset it with a large force of Goths and ten thousand Burgundians sent to his aid clandestinely by Theodebert, King of the Franks. Belisarius wished to despatch one half of the Byzantine army at once

' Of the misery caused throughout Italy by the protracted war, Pro. copius has some anecdotal illustrations to give about this time. In one case a fugitive mother had to abandon her infant in its cradle, whereupon the family goat, attracted by its wailing, entered the hut, and managed to suckle the child effectivcly. This lasted for some time till the villagers returned, when the maternal solicitude of the animal for its anomalous nursling became a spectacle for exhibition in the district. As agriculture was brought to a standstill in many places famine was often urgent, and he mentions the instance of two women killing and eating seventeen men whom they had received as guests, but they were detected and killed by the eighteenth; De Bel. Goth., ii, I7, 20. 


\section{The Ase of Justiman and Theodora}

to its relief, but Narse's disputed the necessity, so that his proposal fell to the grounel. A small force which was sent feared to advance beyond the l'o because of its manifest insufficiency, and when at last Narses had complied with an carnest refuest of Belisarius to stpplement it effectively, it was too late to avert the capture. The city had been ill provided to stand a siege, and, while the inhabitants were reduced to feed on dogs and mice, the garrison, being at the last extremity, were induced to accept terms as to their own safety from the Goths. 'Thus Milan was delivered up, and the barbarians, being incensed beyond measure with the Milanese for their defection, massacred them revengefully to the number of three hundred thousand. When Justinian heard of this caltastrophe, he recalled Narses to Constantinople, recognizing that an injurious division of authority was an incritable consequence of his presence at the seat of war.'

Eirly in the next year (439) Theodebert launched himself on al remarkable enterprise, and, having crossed the Mlps, appeared suddenly in Northern Italy at the head of one hunclred thousand men. With the exception of the king and his staft, all these warriors consisted of infantry, their only arms leeing a sword, a short-handled axe, and a shicld. Their method of fighting was to project the axe with the utmost force abainst their opponeme's shickd, which was thus rendered useless by fracture, and then to attack impetuously with the sword. This formidalile host crossed the Po, and soon came in sight of the (iothic camp), from which joyful aclamations were forthwith sent up in anticipation of the splendid assistance which wis about to be rendered themby

It is curous that among the compluests of Naree in thin campaign

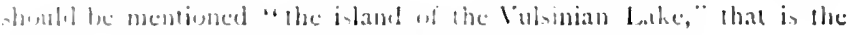

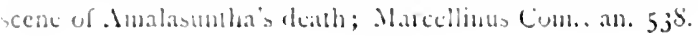


their ally. Soon, however, they found themselves involved in a deadly tumult, myriads of axes were flung, and their disabled comrades were slaughtered on every side, until the whole Gothic army was routed and hurried with headlong speed towards Ravenna. Shortly the disordered bands of Goths were noticed flying across the country by the Roman forces engaged in that district, among them being the redoubtable John, and they immediately concluded that Belisarius had fought a successful battle, and was in hot pursuit of the beaten enemy. All rose expectantly and advanced in the direction of the impulse, when they also found themselves in collision with the invading host, which bore down on them in an irresistible mass. Overwhelmed by the inmensely superior numbers, they turned and, abandoning alt their positions, hurried by forced marches to join Belisarius in Tuscany. The reason of this extraordinary incursion was now clearly apprehended; believing that the Romans and Goths had reduced each other to a state of inanition, the King of the most faithless of nations (the Franks are so characterized) thought the moment opportune to possess himself of a large tract of Italian territory. A remonstrance was at once addressed to him by Belisarius, who appealed to the obligations of probity, and the compelling nature of his previous engagements to divert bim from his purpose. But a better argument was at hand: bivouacked in an exhausted country, with a deficient commissariat and no water supply but the tainted stream of the Po, an epidemic of dysentery soon pervaded the teeming multitude, and they hastened to regain their own habitations after losing a third of their number. ${ }^{1}$

1 At this date the French Kings alone, of the potentates outside the Empire, issued a gold coinage bearing their own effigy. Even the 


\section{j7S The Age of Justinian and Theodora}

Before the summer of this, the fifth year of the war, the Goths had been driven from nearly all their principal strongholds, and Vitigis, with the bulk of his troops, had been obliged to take refuge in Ravenna. But the outprosts of the Gothic capital, Faesulate and . luximum, both strong by nature, and muntioned with especial care, had to be reduced before the hockade of the regal seat could be safely undertaken." Sereral months were consumed in these operations, and the byantinc army was so distressed hy the protracted defence of Auximum, which was attacked by the Master of soldiers in person, that the troops were on the verge of muting. At length the garrison was induced to capitulate with the homours of war, and Belisarius was free to derote all his strategy to the capture of Ravema. 'That city was built in a swamp near the sea-shore, about forty miles below the estuaries of the P'o, and was un.1pponachathly on all sides by an army in force: It was neecessary, therefore, to produce.

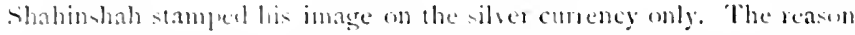

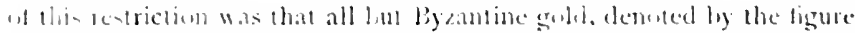
and superaciption of the Eastern binpenon, was cacluded from com.

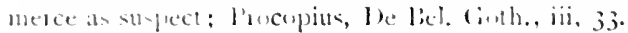

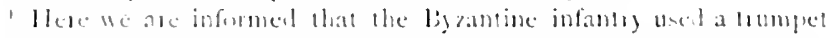
wate of woul and leather, the cavaly whe ef has. They wese, how-

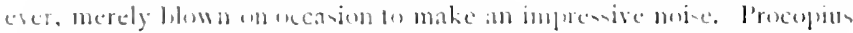

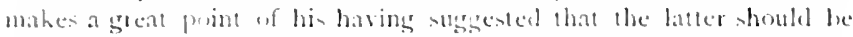

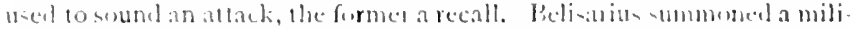

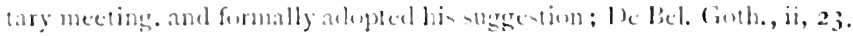

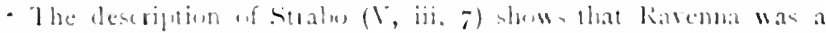

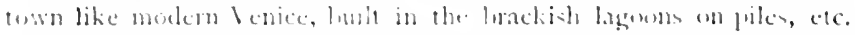

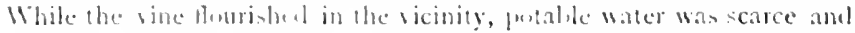
salualle, Hence the juke (Martial, iit, 56, 5i) that wine was cheaper

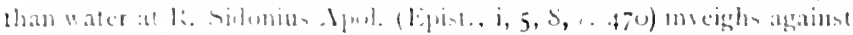

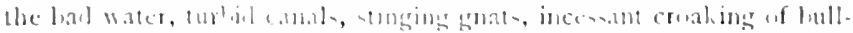

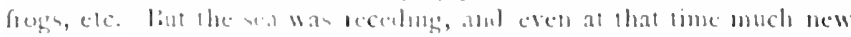

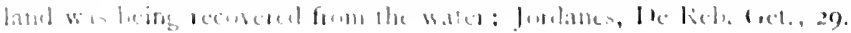


a famine within the walls in order to bring about its surrender. Under the circumstances, however, the Byzantine general possessed every facility for achieving this object. The Goths had neither an army nor a fleet which could succour them from without, and hence the Romans were unhampered while making their dispositions for cutting off supplies from every direction. The environs were hemmed in by their land forces, whilst their fleet rode at anchor off the harbour. At the same time the transit of provision boats down the Po from the fields of the north and west was blocked by guards stationed on the river banks.

Directly Theodebert heard that Vitigis was in a critical position, he made a diplomatic attempt to encompass the subjugation of Italy. A legation arrived with the proposal that the two kings should reign as joint sovereigns, and contingently an army of fifty thousand Franks, which had already surmounted the Alps, should at the first onset annihilate the Byzantines with their axes. A companion em. bassy from Belisarius, who had been apprized of the intended debate, was received in audience at the same time. By them the Gothic king was warned not to put his trust in numbers, but to believe that the Imperial army would find means to deal with a multitude of Franks as effectively as it had already done with his own very numerous forces. Moreover, he urged, the perfidy displayed by the recent invasion proved that no compact would be binding on the Franks. After consultation with his nobles Vitigis decided that he would open peace negotiations with Justinian, and dismissed the envoys of Theodebert with a negative reply. Legates were then despatched to Constantinople, ready to accept any terms of peace which should be granted by the Byzantine Court. 


\section{5so The Age of Justinian and Theodora}

Belisarius now became intent on reducing the foths to the direst necessity through shortage of foodstuffs. Extermally the exclusion of supplies had heen carried to perfection, but he had been informed that the gramaries of Ravenna were well stocked. Bribery of miscreants, effected through the ageney of Matasuentha, the vindictive queen, remored this obstacle to the speedy capitulation of the city. Incendiaries were set to work, and the public storehouses were suddenly consumed by fire. At this juncture plent. potentiaries arrived bringing the Emperor's answer to the peace proposals, which afforded complete satisfaction to the forths. Vitigis wats to reign beyond the Po, and to retain one balf of the regal treasures, while the rest of Italy, and the other half were in future of he subject to Justinian. It was essential, however, that the Master of Soldiers should ratify this treaty, hut when the legates presented themselves in his camp for the purpose he relused to be a party to it, feeling assured that he would soon be master of Ratemal, and of the person of the Gothic king with everything apprertaining lo him.

The Coths now became filled with distrust, and desparied altogether of their fortumes. Vitigis, as an unfortumate leader, had lost their confidence, and they foared that surrender would result in their all heing deported to some unweleome halitation in the last. lo their anxious congtations one way ont of the impass at length presented itself: lielisirius should te their King. and moler his strenuons rule [nosperity would be restorcel to the cioths in Italy. Acting on the impulse, they mate the preposition fermally (1) the gencral, and at the same time a private intimation

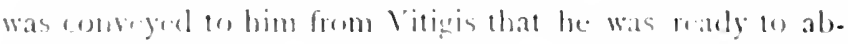
dicate in his favent. Buth his ambition was mot of the anto. 


\section{War with the Goths in Italy 5 S I}

cratic order, and subservience to authority was one of the main features of his character. The promise he had given ingenuously he intended loyally to keep; and in the offer of kingship he saw no more than an incident which enabled him to serve more promptly his Imperial master. He prepared then to profit by the obsequious mood of the Goths towards himself, and to gain his end by an astute policy of compliance instead of by a protracted struggle in arms. His assurances, couched in somewhat ambiguous language, were deemed by the Goths to be tantamount to an acceptance, believing, as they did, their offer to be so tempting as to constitute in itself a guarantee of his good faith. Belisarius now removed from the vicinity of Ravenna on various commissions, all officers with their commands, whom recent events had taught him to distrust, retaining only those troops in whose attachment to himself he had full confidence. With the latter he entered the city and at once proceeded to arrange everything apparently in the sole interest of the inhabitants. He was cordially receired, but the Gothic women were disappointed at the appearance of the Byzantines, and were inclined to rate their own male relatives for allowing themselves to be beaten by men of inferior physique to themselves. A plentiful market was introduced by sea, and all the surplus Gothic forces were dismissed with a safe conduct to their respective homes. Having thus equalized the Roman and Gothic troops in the town, Belisarius repudiated his supposed sovereignty, and declared himself to be merely the faithful vicegerent of Justinian. He completed his measures by placing Vitigis amicably in nominal custody, and took possession of the palace with all its valuable contents.

As soon as the proceedings of Belisarius were disclosed 


\section{S2 The Agc of Justimian and Theodara}

to the (iothic nation in general, they immediately elected a new King, choosing Ildibad, a man of the first rank, for promotion to that dignity. At the same time the Master of Soldiers was being criminated at the Byzantine Court, the worst motives leing attributed to him ly his adversaries; and his recall was shortly issued, but ostensibly merely that he might be at hand in view of the threatening activity of the Peruian monareh. When this news was brought to the Goths, they assumed his imminent disgrace, and made another determined effort to induce him to accept the kingbip. In him they saw the potential saviour of the ir race, and cen Ildilad was moved to declare that he was ready to (leposit the crown and purple at his feet. But lelisarius remaned firm in his resolution: they reminded him of his late lireach of faith, even taunted him with preferring servitude te independence, all to no purpose. Nothing could shate his comviction that while Justinian lived, he was in honour fwund to shun any semblance of rivalry with his authority.

For the second time Belisarius returned to ('onstantinople with a captive king and all the precious externals of majesty in his train. On this occasion, howerer, no pulslic spectack was decreed to celelorate the extension of the Empire, and the suceess of its arms. Perhaps that event was now considered as merely normal by the Court: perhaps the Emperor had felt insignificant in the popular eye when compared with the victorious general who priled the spoils of victory before his throne. The senators were gratified with a sight of the treasures of Thendoric heaped up within the palace, hut the multiture were excluded from comtemplaten of the evhilatrating dieplay. Let the name of Beliatriun wis an every tomgle: and in his daily progresses thomgh the capital he was gaked on with admiration by the 


\section{War with the Goths in Italy $\quad 583$}

inhabitants. He moved about on horseback anid a concourse of his personal guards, all mounted like himself, whom he maintained to the number of seven thousand. Vandals, Moors, and Goths swelled their ranks, and indicated by their distinctive visages with what a variety of nations he had fought. Belisarius was tall and handsome, with a countenance of singular dignity, equalled only by the modesty and affability of his address. In war he was determined and resourceful, but never oblivious of humanity, and always mindful of the interests of those dependent on him. His soldiers were known to him severally and constantly observed, their valour richly rewarded, their losses repaired, whilst they were firmly restrained from all excess. Hence he was adored by the rural population who cane in contact with him, since the grain crops and fruit trees were preserved from damage under his generalship. He was not less distinguished for temperance than for his other virtues; and, although the camp was often thronged with beautiful female captives, he nerer even bestowed a concupiscent glance on them; nor in the use of wine did he ever exceed the strictest moderation.'

'Procopius begins the third book of his Gothic War with this characterization and eulogy of Belisarius. 


\section{('IIIPTER XI}

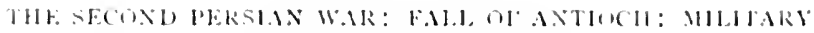
OHEKITIONS IN I..ZICI

Whlle Justininn was thus conquering in the West and substituting his own rule for that of barbarian prentates, the tide of war was rising in the East, and almost similar disanters to those he was inflicting were impending on the integral territory of the Empite.

The trimphal progeress of the Imperial arms in . Ifrica and Italy was watehed with the keenest selicitude by Chosroes, and he began to fedr that the prower and resources of his herelitary rival we re being so formidalily increased that he would sonn be able tw make an incesistible attack on his own dominions. Exen before the formalities of the l'erpetual Prace had lecen eompletely adjusted the news atrived of the virtual suljugation of the Vandalie kinglem; and (bouroes, while congratulating the Emperor by his legroles, jestingly pen forward a cleim to share in the spoits, which, he observed, rould not have been won but for his own ready

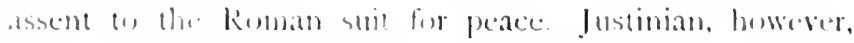
work his banter setionsly, and presented hom with a latre (4) of money ats a conciliatory gift.

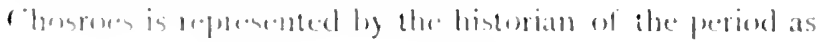

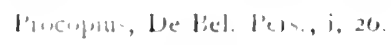


a man who talked humanity and philosophy in a most engaging manner, but with treacherous intent, and who never failed to take advantage of his opponents after he had lulled their suspicions by an outward show of sympathy and benevolence. " Whatever his individual inclination may have been in 539 as to the expediency of entering on a war with the Empire, ample incitement from without was not wanting to induce him to bend his mind intently to the question. While Vitigis was struggling to retain his kingdom the natives of Roman Armenia were in revolt against Justinian's newly imposed taxes and stricter system of local government. ${ }^{2}$ Hoping to divert the armaments of the Emperor from themselves, both partics successively sent legations to Chosroes urging that in his own interest he should make war on their oppressor. If he did not take up arms in time, they argued, his encroachments would continue unchecked, and Persia would shortly find that no option was left to her but that of being devoured last. To such representations the Persian monarch was quickly responsive, and in each instance the emissaries departed feeling satisfied that their object had been attained. ${ }^{3}$

1 Procopius, De Bel. P'ers, ii, 9. The veneration of the I'ersians for truth has been referned to in a former chapter, but in actual fact deceitfulness was a prominent characteristic of the nation. Thus Horace alludes to the "lying Persians" ("infidi Persae," Od., iv, 15) as the verdict of common experience. Truth was rare and preciums in Persia, and esteemed accordingly. The opinions of modern travellers coincide. See Miiller, Encycl. Bril., xxii, p. 663; cf. I'algrave, Ibid., ii, p. 248.

2 In this rebellion they managed to kill Sittas, Theodora's brother-inlaw, and, it was said, ly the hand of Artabanes, who joined the Imperial service soon after, and so much distinguished himself in Africa. see p. 522.

3 Procopius, De Bel. Pers., ii, 2, 3, whence the narrative proceeds as below. 
In the autumm of 539 (hosroes made up his mind to wage watr with the Romans, and cist about him for some plusible pretext to hegin his military eferations. He accused Justinian of tampering with the allegiance of his Suracenic ally . Mommondar by permiary inducements, of bribing the 11 uns to imsade l'ersia, and finally he instigated the . Trab sheikh to make a rail inte sigria in order to provote a declaration of watr from his rival. Itustinian, however, wats very amsious to keep the peace, and ahlesesed a dignified evpostulation to the Persian Court, in which he exhorted the shahimshath to deal with him in good faith. 'Po this apleal Chosroes deigned no reply, hut retained the ambassador till he bad matured his preprations for invaling the Empire. In the spring of $5+0$ he crossed the Euphrates in great force, and adranced along the river for four hundred miles until be arrived in the vicinity of Callinicum. I)tring the later third of this march he was on Roman territory, where be exacted a pecuniary ransom from some small towns, and destroyed others. At this point he dismissed Iustinian's legate, telling him simply to go and inform his master in what prut of the world he had left Chosroes, the son of Caviules.

The whoke of syria was now at the merey of the l'ersiem king, and deputies arrived on all sides to incpuire what amount he would accept in order to leave their districts un. molested. A small force stationed at Hicrapolis was deserted by its commander, Fumes, who disappeared suddenly and foregt to leave his adelress. ('horexes seom appeared before the walls, but he allowed himself to he bought off for two thousand peumels of silver; and from theme he proceded further on his deprealations, hut his price rose as be went alomg. At Beroea, a mun smaller place, having been paid 
a similar sum, he demanded more, and, in default, ended by sacking and burning the town. At the same time he was convened by a bishop on the part of the Antiochians, who offered him a thousand pounds of gold $\left(£_{40,000}\right)$ to quit the country. To these terms he agreed, but when the bishop returned to Antioch to clinch the bargain, he found that legates had arrived from Constantinople, who issued a prohibition against the Syrians continuing to buy back the Emperor's cities from the Persian monarch. Having received an intimation, therefore, consonant to this decree, Chosroes marched with all speed against the city.

Antioch, with a previous history of eight centuries, was the great commercial emporium between the Far East and the West; and it is supposed that the term Ta-Thsin, ${ }^{1}$ which represents the Roman Empire in Chinese annals, is a travesty of the proper name of the overflowing Syrian mart, of which alone they had any practical cognizance. Under the Empire, its history is especially dignified by the names of Julian, Libanius, and Chrysostom. But it must have been shorn of much of its splendour by the disastrous earthquake of 526 , an account of which has been given on a previous page. ${ }^{2}$

The city was situated in a plain about two miles wide between the Orontes and Mount Casius. On the north the river, which flowed past the walls, afforded adequate protection, but on the south two spurs from the mountain projected to such an extent that part of the city was built on

1 See p. 193.

2 Founcled and developed by Macedunian Kings of Syria, begimning at 300 B.C. For a full history, see Muiller, Antiq. Antioch., Götting., I 839. For a topographical and sociological account the bulk of the materials are to be found in Libanius, Chrysostom, and ]n. Malala. 


\section{jes The Age of Juslinian and Theodora}

their derlivities and in the valley between them. On that side, consequently, the fortifications were disposed in two loops, which rose over the hills with a dip in the interspace. The monent information as to the hostile irruption was convejed to Justinian, he sent his nephew, (icrmanus, with a small brigade, to the seat of war, promising him that large forces should follow with the least possible delay. On his arrival, (iermanus inspected the fortifications, and observed that on the summit of one of the hills masses of rock arose at a short distance outside the walls, which they almost equalled in height. Hence an enemy, by occupying this chevation, could dominate that part of the town. He advised, therefore, that a decp foss should be excavated so as to render the walls inaccessible on that aspect, or that a huge luwer conjoined to the wall should be built opposite the rocks, which could thus be rendered untenable by showers of missiles. The local engineers, however, decided that there was no time to undertake works of such magnitude, whilst an unfinished attempt would only advertise the conemy as to the weak point in the line of defence. Shortly afterwards, Germanus, having no news of a byzantine army being on the route, retired into Cilicia, giving as his reason that the presence of a prince of the blood would be an incentive to Chosroes to exert all his force to capture the city.

When Chosroes reached Antioch, he was still willing to aceept a ransom, but the citizens were now in no mood to meet his proposals. A certain number, the most timid, hatd already fled, but those who remained were suddenly reassured by the arrival of six thousand troops from the south under the military governors of libanus. Ilaving encamped his army along the Orontes, the Shah sent forward an interpreter to interrugate the municipality as to a 
ransom, but a mob congregated on the walls immediately overwhelmed him with jeers and insults; and shortly he had to run for his life in order to escape from a shower of stones. Burning with resentment, Chosroes now commanded that the siege should be pressed on all sides with the utmost ardour. He himself, with the most strenuous body of troops he could select, ascended the southern hill, where he took up his position on the rocky plateau, from whence, with all the advantage of being on level ground, his men began to discharge their arrows with tireless energy against the defenders of the wall. On their side the garrison had improvised a means of doubling their powers of resistance by erecting a wooden platform above the battlements in the interspace between the pair of towers which confronted the threatening ridge of rock. From thence soldiers commingled with citizen volunteers, in superimposed ranks, launched their darts against the enemy. The battle with missiles raged hotly for some time, when suddenly the wooden platform, imperfectly sustained, gave way with a loud crash, and precipitated all those who were supported by it to the ground. A senseless panic then ensued, a cry was raised that the Persians had forced the wall and were pouring into the city, whereupon the newly-arrived garrison descended and leaped on to their horses, which were tethered below, and rushed to the gate of Daphne on the opposite side of the town. Their leaders rode at their head, and, wishing to get away without hindrance, scattered the news that Buzes was at hand with an army of relief, which they were hastening to admit into the city. But the citizens thronged after them excitedly, and a fatal crush occurred in the vicinity of the gate, where people of all ages were trampled to death by the horses of the flying cavalry.

II. 


\section{The lge of Justinian and. Theodora}

In the meantime the Persians, secing the walls deserted, brought up ladders, and, ascending in great numbers, took possession of the hattements. 'There they remaned for some time. for Chosroes, seated outside on a high tower, having noticed the flight of the military, thought it wisest to give them time to evacuate the cits, instead of provoking them to rally by an untimely attack. As soon as the tumult appeared to have subsided, the l'ersians begin to descend and make their way into the level part of the city with some difficulty, as the tract adjoining the south wall inside con. sisted for the most part of precipitous crags. ln a short time, however, they mexpectedly found themselves in conflict with a large mass of the youth of Antioch, members of the Circus factions, who had assembled in the forum, some armed in military fashion, others provided only with stones. The first bands of the Orientals were screrely repulsed, and already the syrio-Greeks began to sing the patan of "fustinian the lictor," when large forces arrived and extinsuished their resistance. A ruthless massacre then followed, neither age nor sex being spared, until the shah thought fit to give the signal for its cessation.

Previous to the commencement of the siege, the Roman legates had heen received in the leersian camp, where they banly endearoured to dissuade Chostoes from continuing the war. He now summoned them to his presence, and, in a larrmose tome, delivered a homily on the diversiffed nature of human fortune. The ruin of this nolse capital, he remarked, was a sad spertacke, which he hat done all in his power to prevent. By their rash defence with une qual forces, the eitians hatd lorought this calamity on themselves, but he had restraned the incensed soldiery and given time for great numbers to escape. 'The arrogance of mortals, he continued, 
was visited with condign punishment by the Deity, who sought to restrain them from encroaching beyond their proper sphere. He pointed at Justinian, on whom he cast the whole onus of originating the war. But to his hearers it seemed that only wanton aggression had impelled him on this campaign, whilst all understood that he had delayed the assault discreetly lest his own army should incur necdless risk.

The fate of Antioch was presently decided. All the remaining inhabitants were seized as captives, and the buildings were given over to pillage and fire. Treasures of gold and silvel and works of art in marble were accumulated for the special benefit of the Shah, who departed, leaving incendiaries in the city to complete the task of destruction. Ultimately, however, Chosroes showed himself as a benignant master of the Antiochians whom he had carried off. In the vicinity of Ctesiphon he built a new city, to which he gave the name of Chosroantioch, and furnished it with everything appertaining to a Roman town, including a circus and public baths. Here the captives were housed under the eye of the monarch himself, with no intermediary satrap, and endowed with many privileges which were not enjoyed by his Persian subjects. Moreover, if any of the relatives of the inhabitants, who had been enstared, succeeded in escaping to this town, they were granted a permanent asylum, so that their masters could not reclaim them, even shoukd they be nobles of the court. ${ }^{1}$

It might be said, without much sacrifice of accuracy, that the war which had now broken out between Rome and

1 On the taking of Antioch, etc., cf. Jn. Lydus, De Magistr., iii, 54. Not a taxpayer was left in Syria, he says, hut nevertheless the Rector had to extort the revenue out of the province in some way. 


\section{The Ige of Justinian and Thodora}

Persia only terminated a century later, when the Sassanian dynasty was extinguished by the rotaries of Mohammed. There were interruptions to hostilitices, vicissitudes in the matial retitions of the two empires, yet me stable peace. But the saracens them became the neighbours of Rome on the Euphrates, as they had always previously been on the Arabian frontiers: and, viewing the conflict as one letweren East and West, between Geeian and Orientil rivilization, we might traserse a millemium and aser that the war never ended until 1.53 , when Mohammed II mate his vietonions entry into Comstantinople. Henceforward Justinian was almost perpetually engaged in desultory and indecisive military operations on the castern marches: and the repair of damages infleted by his restlens comprer constituted at permanent drain on the resources of the Empire.

After this signal success there wals a lull in the actirity of (hosroes, and he showed a disposition to srant a peace. He discussed the subject with the liyantine emoys, and finally disnissed them with a precise statement as to what terms he would accept. " Ie then took a pleasure trip to the sea at selenciat, the port of Antioch, vinited the grove of baphne, after which his greed for acquisition returned, and h. bethonght himself of the rich city of Apamea, which was in the sicinity. Ile appeared before the gates, but, ats an informal truce was supposed to be in existence, he professed himself to he an amicable visiter, desirous only of viewing the objects of interest in the town. He was arlmitted with a gruad of cavilty, and presicled in the circus in imitation

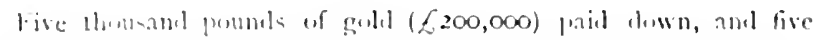

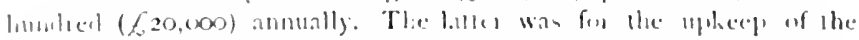

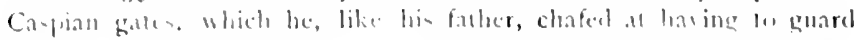

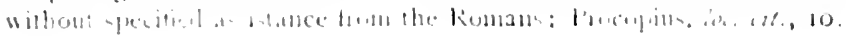


of the Byzantine autocrat. Hearing that Justinian faroured the Blues, he announced himself in opposition as a partisan of the Greens. As, however, his temper was uncertain, it was thought prudent to conciliate him with a gift of a thousand pounds of silver before his departure; but, still insatiate, he insisted also in appropriating the treasures of the cathedral.' He now discarded all respect for the peace negotiations, and resumed his career of subjugation. Ransoms were exacted as before, and he decided on the blockade of Edessa, but was deterred by the evil omen of a boil on his cheek. He then laid siege to Dara, and drove a tunnel beneath the walls. His design, however, was betrayed, and frustrated by a counterwork on the part of the besieged, whereupon he abandoned the enterprise and returned to Persia for the winter.

Justinian now repudiated the peace convention, which had been made by his legates, on the ground that Chosroes had violated the conditions; and in the spring of $54 \mathrm{I}$ Belisarius arrived at Dara to organize the defences of the country. The result of a military council was an advance, with all the forces which could be mustered, on Nisibis. Here the usual round of skirmishes were fought outside the walls, but at length it was decided that the fortress was impregnable, and the Roman army retired. A conflict with the

1 Apamea was one of those places where a lng of wood, said to be a fragment of the true cross, was preserved and renerated. On this occasion it was brought out and paraded, a miraculous light following the Bishop as he went on his round with it; Procopius, loc. cit., 11 (by hearsay); Evagrius, iv, 26, who says he was taken to see it himself when a schoolboy. Chosroes did not allow his soldiers unbounded licence. Thus, when a citizen of Apamea complained that his daughter had been ravished, he hanged the man, in spite of the prayers of his comrades. 


\section{$59+$ The Age of Justinian and Theodera}

Shah had been expected, hut he was re ported to be occupied with a Hommish incursion, and did not mate his appearance on the Euphrates this year. After directing some raids on lecrsian territory, in the course of which sisaurammm, an important fortress, with its garrison, was captured, liedisarius returned to Comatamtinople for the winter. Arethas, the saracen sheikh, with a large following, took part in this expelition, and even crossed the Tigris into Assyria; but, being ill-directed and supported, rendered litte effective service. The Persian soldiers who had been taken as prisoners of war, about eight hundeed in mumber, 'Here sent to Italy, there to do duty as combatants against the (ioths.

In the meantime Chosroes had really absented himself on an expedition which he had undertaken insidiously against digantine commerce in the Euxine Sea. After the Iari and Iberians had taken refuge in the arms of Rome, Iuntinian had procecded to make his suacrainty practical hy huilding a strong fortress on the eonst of lazicat. Founded among inaccessible rocks, and approachable from the plain on one side only, this stronghold received the appropriate mame of Protra. A pair of military Dukes, distinguished as usual for rapacity, were placed in chatsere, and they immedi. ately created a monopoly in the.ir own farour of the imports ly sea, on which the Laki were almost wholly dependent. The region, in fact, was devoid of agricultural produce and salt. ${ }^{2}$ lor such meressuries they bartered slaves and skins. sion the fiscal eppersion lerame so intolerable that deputies were secredly despatehed to implose the lecrsian King to tatie up arms on behalf of the lati and cxpel the komans. (houroes seiked the opportunity, and, giving ont that he was matching against the llums, procecded with a

$$
\begin{aligned}
& \text { frocupiu, inect., } 2 . \\
& 2 \text { lind, } 15,25 \text {. }
\end{aligned}
$$


numerous army to the occupation of Lazica. The country was shut in by precipitous mountains, but level passes existed, which, however, were blocked by a dense forest. With the aid of native guides and a strong body of pioneers, a route was quickly opened, so that the Persians poured in rapidly and disposed themselves for an assault on Petra. At the onset they suffered severely through a ruse of the Byzantine commandant, who withdrew all his men from the battlements so as to give the fortress a deserted appearance. The Orientals, therefore, crowded up carelessly, and began to arrange their siege engines in suitable positions, when suddenly the gates were flung open, and the garrison, charging impetuously, drove them back with great slaughter. Within a few days, however, the resourceful author of this success was slain by an arrow, and thereafter the defence became languid and ineffective. Two great towers were the chief bulwarks of the town, and the Persians, without being observed, bored a tunnel which terminated under the base of one of them. Then the stone foundations were cautiously removed and substituted by a mass of inflammable wood. On fire being applied, the ponderous pile soon collapsed; whereupon the besieged gladly accepted the terms offered them to surrender. The treasures of John Tzibus-such was the name of the Duke who had been in command--which he had amassed by his extortions to a large amount, fell into the hands of the victor, who then evacuated the principality, leaving a Persian garrison in the fortress. Chosroes was now in a position to ruin Byzantine commerce in the Euxine, but it was first essential that he should build a fleet in order to make his conquest of Petra effective for the purpose. In order to guard his retreat during this expedition, the Shah had impelled an irruption of Huns into Roman 


\section{Thi Ase of Justinian and Thedora}

Simenia, hut they were met and defeated by the Master of siddiers in that region, whe, howerer, neglected to follow up his suresso, being igmoramt or misdireeted ats to the op'sortunity of interecenting the l'ersians on their way through the mountain passes of Lakica.'

The jusubiciency of the Byantine fores in the East was such that neat year $(5+2)$, when Belisarius returned to the weat of war, he was obliged to trust wa a ruse to stop the proEress of the l'ersian army. Chosroes again led the invasion, and this time with Jerusalem as the object of his cupidity. when he heard that a Roman camp had heen formed on the river, suuth of the fromtier, su as to intercept him should be return by his usual line of mareh. Thereupon he sent an exploratory legation, ostensibly to interrosate the Naster of Soldiers as to Justinian's intentions with respect to a treaty. llaving named a day for their reception, belisarius advanced from his camp accompanied by six thousand of his tallest soldicrs, chosen from as many diverse nationalities as possible. When the time of meeting was at hand, he appeared reclining in an extemporized tent, as if resting after a hunting expedition, whilst in rarjous directions, as far as the eye could reach, were seen Thracians, Mysans, (ioths, Merules, Vandale, and Moors, all in undress, hurrying to and fro, reconingly lusied with maters relating only to the elase. On the oppesite side of the river a thomsand cavalry were divposed, making as much show an possible hy their crolu. tions. When the Persians came up, Belisarius, regarding them in at fuectioning mamner, with an atir of reprellant surprive, inpuires? what might be the object of their visit to his rampl. St the same time the men, passing and repassing, wne with a borsewhip, mother with an ase, a sword, or a 
bow, gave them a look of careless and contemptuous scrutiny, and went on as if too intent on their occupation to notice them any further. In reply to the general, the chief legate said that the Shah was indignant at Justinian's not having sent an ambassador with a definite answer as to the proposed treaty. "It is not customary," said Belisarius in a haughty tone, "for people to act like Chosroes-to invade a neighbouring kingdom with a great army, and then to inquire what pacific measures would be most acceptable. Withdraw your forces; we decline to treat with you unless upon equal terms." Making a gesture of dismissal, he then turned away and began to occupy himself with something else.

Duly impressed by this burlesque, the envoy reported to Chosroes that he had never met a general so decided and authoritative, nor seen soldiers of such splendid proportions, whilst the main army must be very numerous, since so many could be out of arms at one time as a mere hunting party. Moved by this report, the Shah thought it prudent to retreat across the Euphrates at the spot where he found himself instead of retracing his usual route to Ctesiphon. Thus was Palestine saved; and by many Belisarius was credited with a finer achievement than when he led Gelimer or Vitigis captive to Constantinople. Yet it was the last occasion on which he held a command in the Orient; and his activities in future were to be confined to Italy and the vicinity of the capital. Even on this occasion, however, the Persian monarch did not regain his capital empty handed, but, finding on his way back that Callinicus was poorly fortified, he took it by a sudden assault, and made a clean sweep of everything worth removing from the site.

During the following year, owing to the prevalence of a fatal epidemic, Chosroes remained inactive; but the Romans 


\section{S The Age of Justimian and Theodora}

penetrated into Persarmenia, where they carried on the war with little sucress, and sustained at least one decisive defeat. In 54., however, the Shah again emerged from his bounchries, this time resolved on the cilpture of Edessa, a city which athrmed itself to possess a direct grtarantee from the l)eity that it would never be taken by an enemy, and a passage to that effect from a letter, said to have been written by Jesus to Algar, a former ruler, was inscribed over the vates. But Chosroes was ambitious of disproving the validity of this safeguard, and, therefore, set about beleaguering the city in a manner which should exclude the possibility of being unsuccessful. His ardour in this undertaking was sustained by the fanaticism of the Magi, who, having adored Iesus at his birth, ever afterwards regarded him as an impostor most obnoxious to their religion. $A$ preliminary skirmish, however, having turned out unfavourably for his arms, be began to dread the disgrace of failure, and proposed a ransom; but the amount was so exorbitant that the citizens clected rather to endure a siege. Preparations for capture were, therefore, pushed on energetically; and first of all the Persians began to construct an immense fuadrangular mound, from the flat top of which they intended to dominate the rity with their missiles. Trunks of trees, stones, and carth were congested together, in the beginning at a distance leyond bow-shot from the walls, but as the work progresced towards the town, the builders became attainable by the arrows and engines of the garrison. The discharge was at first effective, especially that of flaming clarts, but the Orientals soon erected buge screens made of hides, under cover of which they were able to work in safety. The citizens now became serinusly alarmed, and sent a further deputation to Chosroes, but in vian, fifty thousand pounds 
of gold $\left(£_{4}, 000,000\right)$ being the lowest price he would accept to raise the siege. All hope of an accommodation being now lost, the engineers of the city began to devise means to counteract the hostile operations. First they tried to raise a mound, conjoined to the walls, to oppose that of the enemy, but the task proved to be beyond their powers, and so they desisted. Then they bored a tunnel, which reached as far as the centre of the mound, designing to destroy it by fire from below, but the Persian sentinels heard the excavators at work, and the scheme was frustrated by a counterboring. Another tunnel, which only attained the proximate part of the mound, was achieved with better success, and a cavern was hollowed out, into which a vast quantity of dry wood impregnated with oil, sulphur, and bitumen was introduced. Here a fire was kept buming constantly by fresh supplies, whilst the enemy's attention was diverted from the rising smoke by an incessant discharge of blazing arrows and pitch-pots. After some days, however, as the fire pervaded the viscera of the mound, volumes of smoke betrayed the real nature of the conflagration. The Persians then essayed to extinguish it with earth and water, but, failing to check it, they decided to abandon this siege work. A surprise attack by night with ladders was the next manœuvre, but the Romans were too vigilant, and the coup only led to a slaughterous repulse. During the whole period of the beleaguerment, sallies were regularly organized by the garrison, and generally with considerable loss to the besiegers. Finally Chosroes nerved himself to make a supreme effort with all his powers to storm the city. With this object in view, myriads of adobes were moulded and laid over the top of the smouldering mound. The assault was begun in the early morning, and at first bid fair to be successful, the 


\section{The Ase of Justimian and Theodora}

defonelers of the wall heing compatatively few: hut, as the day wore on, the whole cffective propulation - men, women, and rhildren, crowded to the battements. Then inprovised projertiles of erery avalatsle substance were hurled, cauldrons of oil were hrought up and fired along the top of the wall, and, with the atid of sutable sprinters, drops of the burning lipuid were rained down on the escalitders. - Vifer a probunged and vigorous attack, the besiegers retired and informed the shah that they could make no headway. lle raged, and drove them hack again: they returned to the assiult with reckless fury: ladders, towers, and engrines of cvery description were rushed up to the walls. but for the second time the ceascless torrent of missikes put them to flight. (hosroes then resigned himuelf and ledt his post of observation, while the townspeople hurled their taunts of defance affer his retreating figure. The siege of Edessa had falled; and, with the slight compensation of five hundred pounds of gold ( 20,000$)$, he broke up his camp and departed.

Shontly after Iustinian's legates again comvenced chosroes and in $5+5$ he granted a truec for five years in exchange for wo thousand pounds of sold (S.So,000). and a (ireck physician, whose skill had formerly relieved him from a painful madady.' Yet such was his ill fath that when he sent a plenipotentiary to conciude the pact at constantinople, he commineioned him to attempt the capture of l)ara, while on his way. by at stratagem. But for the wariness of the inhabitants of that fortress, the emonsary would hase samed atminsion with a lasge retime, fined the houses in the night, and efrened the gates to the army of Nisilis, whith wats to lice in wating out virle the wall?.

$$
\text { (6. Lachamd, .y, si, } 7 \text {. }
$$




\section{Military Opcrations in Lazica}

Notwithstanding the establishment of peaceful relations, a desultory warfare was still carried on in Lazica. I twelvcmonth's experience of Persian domination convinced the Lazi that there was something even worse than Byzantine extortion, and they prayed to be received again into the fold of a nation which was at least Christian like themselves. Nor could the Romans endure the loss of Petra, but sent an expeditionary force into the country to retake it. They' were opposed by a Persian army, and for many years the principality was the scene of numerous petty successes and defeats. Chosroes imported a large quantity of material for the purpose of building a fleet on the Euxine, but it was suddenly consumed by lightning, whence it happened that the command of the sea in these regions was never obtained by the Persians.

Intermittently the siege of Petra was pressed for eight years before the stronghold again came into the hands of the Byzantines (55I). The successful general was Bessas, who, though above seventy years of age, was the first to ascend the scaling ladders at the last assault. The defence of the fortress had been persisted in by the Persians with extraordinary fortitude; and out of seven hundred and thirty men of the garrison, who were taken prisoners, it was found that only eighteen had not received a wound. Five hundred of the survivors took refuge in the citadel, and in spite of an earnest exhortation by Bessas, preferred death by fire to surrender; whence all of these perished in the flames with which the Romans consumed the buildings. The fortress contained a store of provisions calculated to last for five years, and the reserve of arms and armour would have sufficed to fit out each man of the garrison five times over. But the captors were chiefly amazed at seeing a copious flow issuing 


\section{The Age of Justinian and Theodora}

from an appleduct, although every channel of water supply had apparently been cut off. In the only possible track a surface conduit had been divided, but for hong afterwards no signs could be detected of a lack of water in the town. Evidently there must he a second supply: they dog down and came on an underground conduit hencath the first, and that also was severed. Only after the capture of the fortress was it chiscovered that at a still greater depth a third watercourse for the supply of the imhabitimts hat leen constructed. Petrat wats now abulished by bessas, who raced coery building to the gromend level, and departed with his prisoners to the capitat.

Two scars after the hegimning of this war an outbreak of l,ubonic plague, the lirst circumstantially recorded in hislory, was manifested in the Eastem llemisplere. The phenomena of the disease were first moted at l'chusium, whence it spread throughout Egapt on the one hand, and Isia Minor on the other. In the spring of the next year $(5+3)$ it reached Comstantinople, where it raged for four months. At first few persons were stricken, hut the epidemic becane intensified gradually, until at the height of its virulence as many as ten thousand rictims died in one day. The cessation of all normal activities of social life, and the changed aspect of the lmperial cappital have heen de scribed by l'recopitus, who was present there at the time. beserted strects, except for those hurrying to bury the deat without religions rites: the oppletion of all odinary sepul-

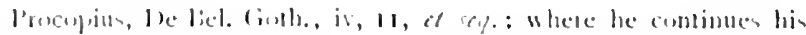

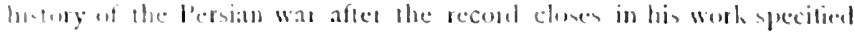
1., thal -uljecl.

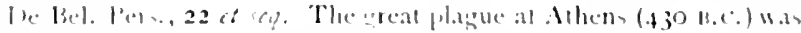

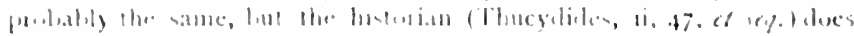

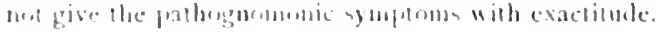




\section{Epidemic of Plague}

chres and cemeteries; the digging of graves in every available patch of ground in the suburbs; the ultimate difficulty of disposing of the corpses by any recognized method, when some were projected into the sea, and others were hurled down the wall towers of Sycae, the roofs having been temporarily removed for the purpose; the stench afterwards pervading the city when the wind set from that quarter; the wailing of the bereaved and the fearful who betook themselves to the churches; the opulent households in which sometimes a few slaves were the sole survivors of the family; the dying left untended and those who fell dead in the thoroughfares while conveying their relatives to the tomb; finally the obliteration of the feud between the Circus factions, and their dejectedly working in harmony for the removal of their own dead and those of others; such were the main features which denoted the state of hopeless desolation prevailing during this calamitous visitation.

The symptoms of this plague have been described by the contemporary historian with an accuracy which leaves little to be added by a modern physician having a clinical acquaintance with the disease. In typical cases the victim at some unexpected moment felt a sharp stab, almost invariably in the groin or the axilla; whence the superstitious declared that they had seen a demon who at the critical instant approached and struck them. Fever, with the development of a bubo at the sensitive spot, rapidly set in; coma or delirium then supervened, and death occurred in three or four days. Black patches often appeared on the body, and were premonitory of an immediately fatal ending. Among the worst signs, vomiting or spitting of blood was also observed. In the most violent attacks the patient without warning fell down in contortions and died before other 


\section{Got Thi Ase of Justinian and Thodora}

symptoms hecame apparent. Some rushed madly through the street, others flung themselves from windows or roofs. The disease was not contagious, and those who handled the infected bodies were men on that aceount more liable to be seized. Renvery was forecasted by ripening and suppuration of the huboes, whilst indolence of those tumours was surely indicative of a fital termination. The medical faculty dissected the corpses with assiduity, hut found neither exulamation nor remedy. In their prognosis also they were wfen wrong, some recovering whom they had given up, and others dying, of whom they had entertained the best hopes. Having once manifested itself, the plague became endemic, and mole than half a century afterwards continued to be rme of the chief causes of mortality.'

1 Evagiu, ix, 29. A long and lugulrious account of the plague is given liy fohn Epher. (IIit. ad ati. Com., p. 227, it sag), not only a $\mathrm{Cl}^{2}$, but in Asia and Eggpt. It lackis, howerer, the precision of Hhat of Procoplus. 


\section{CHAPTER XII}

PRIVATE LIEE IN THE IMPERIAL CIRCLE AND ITS DEPENDENCIES

HILE the diplomacy of Justinian and the strategy
of Belisarius were apparently dictated only by motives of state policy and military expediency, there were private influences at work, which modified considerably the execution of their projects. The feminine proclivities and prejudices of Theodora and Antonina on more than one occasion diverted both men from the course which their better judgment inclined them to follow. Distinctive as were the characters of the Emperor and his most renowned general, in the quality of uxoriousness their similarity was complete. In order that the power exercised by the women in question over the destinies of the Empire at critical periods may be realized, it is necessary to refer to some domestic incidents which exemplify the extent of their conjugal gynarchy.

When Belisarius and his wife set out for Africa they were accompanied by a young Christian proselyte named Theodosius, whom they had affiliated as their adopted son. Of this youth Antonina became intensely enamoured, and succeeded in establishing an illicit intercourse with him, which was obvious to every member of the household except her too trusting husband. During their stay at Carthage BeliII. R R 


\section{The Age of Justinian and Theodora}

sarius entered fortuitously a remote chamber of the palace, where he surprised his wife in company with Theodosius, whose dress was disordered in a manner which indicated unmistakably the nature of their commerce. The general was about to express himself indignantly, when Intonina, with perfect assurance, explained: "I have just come here with this young man in order to hide the most precious objects in our share of the booty from the cupidity of the Emperor." Her husband stifled his suspicions and, blind to the evidence of his senses, retired submissively, leaving the youth in the act of adjusting his clothing so as to accord with the requirements of decency.'

'This intrigue went on, therefore, indefinitely, but at Syracuse a slave-girl, named Macedonia, vengeful or indignant, revealed it in precise terms to Belisarius, and produced two of her fellow-slaves to corroborate her evidence. The general was comvinced, and swore not to betray his informants: and thereupon charged some of his military intimates to make away with Theodosius. They, however, more solicitous as to the farour of his wife, gave the paramour a warning in conseguence of which he fled to Ephesus." At

' I'recopils, Anect., I. Except where indicaled, nealy the whole of this chapter repents on the lirst four sections of this work.

- (n this occasjun Constantine, a sub-general, who bas been menfinned (plp. 564, 567), remasked: "I should rather hase ged rid of the woman than of the young man." During the segre of kome by the Goths this Combantine was stmmoned before belisarius on a charge of appropriating some salualite spoils. An altercation costled, and the offender, concluting rather hastily that he was about to be comlemned to death, made a ruth at the Master of Soldiers with his drawn swert. Ile was immedialely seizel and slaughtered in the antechamber at the command of beli-arius, or, al leas, with his acyuiencence. This somew bat arbitrary cxecution was attributel to the vergeance of Antonina, to whon the above remark had been reporled; Ancel., 1 ; De licl. Guth., ii, S. 
the same time Antonina managed to persuade her husband that she bad been calumniated, with the result that he surrendered the three witnesses to her discretion. They perished by a cruel death at the hands of their mistress, who killed them by torture, and had their bodies thrown into the sea. In the next phase of the intrigue we see Antonina in conflict with her son Photius, whose animosity against Theodosius was such that the latter refused to return to the embraces of his mistress unless he were expelled from the household.' This end was achieved by domestic persecution, and the paramour was shortly afterwards reinstated with the comnivance of Belisarius himself. When the Master of Soldiers was sent into Mesopotamia against Chosroes, Antonina, contrary to precedent, remained at Constantinople to enjoy the society of her lover. Dreading, however, the interference of her son, she plotted to encompass his death. In self-defence he brought forward irrefragable evidence of the adulterous life that his mother was leading, whereupon Belisarius engaged him by a solenm compact to punish the enemy of his conjugal peace. With this design Antonina was summoned to join her husband, and consequently, as had been foreseen, Theodosius betook himself to his retreat at Ephesus, where he had attached himself to a religious fratemity. Photius followed on and, having made himself master of his person, caused him to be detained under strict surveillance.

It was in this year (541) that Chosroes undertook his expedition into Lazica, thereby denuding Persia of his most effective troops. For an enterprising Roman general the

1 I have overestimated the age of Photius on a former page (348), who (from Anecl., 2, and De Bel. Goth., i, 5) must have been eight or ten years younger than his father-in-law. 


\section{bos The Ase of Justinian and Theodora}

way lay open through the richest part of Assyria to Ctesiphom, where were congregated the captives and spoils of Antioch, within reach of a straterical matreh. liut betisarius could not persuade himself to quit the sicinity of the frontier, intent as he was on settling his relations with his wife; and on hearing of her approach he retreated with his forces to a position which enabled her to join him. Subsepuent events in this comection now become merged in occurrences which I have yed to relate.

('hostoes, on his side simultancously, was beset with unlowarel circumstances. Owing to the barren mature of l azira his army was ill-provided with necessaries, and many of his soldiers had perished through disease and want. I mutinous spirit became rife, and during their retreat, hearing of the successes of Belisarius and Valerian, they feared to be cut off in the rocky passes commanded by heights accessible to a hostile force. The shah was assailed with reproaches for having entered unadrisedly on a war with a nation of so mueh political competency, and he began to be alarmed for the security of his throne. In this strait his good fortune had provided him with a remedy of a peculiar kind, which cmanated from the assumption and indiseretion of the Byzantine Empress herself. Zaherganes, his most influential adviser, had received a letter from Theodora, to whom he was personally known, imploring him to incline his master to grant romsiderate terms of peace. "Should you achicese this object," she added, "I can promise you a splendid recompense on the part of my husband, who is absolutely dependent on my advice." Having read this epistle Chosroes incpuired of his staff whether at state could be efficiently gorerned in which a woman exercised such a preposterous ascendancy. 'They agreed unanimomsly that such an adver- 


\section{Private Life in the Imperial Circle 609}

sary did not deserve to be considered seriously, and acquitted the Shah of having acted rashly in embarking on a war with them. Confident, therefore, in the imbecility of the Byzantines, they resumed their march and soon arrived safely within the borders of their own country.

So far in the course of my narrative we have often seen the names of Theodora and Antonina coupled together, but merely in juxtaposition. As I proceed in my attempt to elucidate the sequence of events we shall arrive at a point of time when their lives actually become mingled. Some retrogression, however, is necessary in order to enter on the political track of Theodora nearer its beginning before we can reach those entanglements in her secret machinations where concerted action between the two women becomes apparent. I have already alluded cursorily to the circumstances under which Queen Amalasuntha met her death, ${ }^{1}$ but the most effective cause of that crime was one which remained hidden from the public. In addition to her royal descent, which was derived from a long line of kingly ancestors, the Gothic queen was a woman of great personal charm, of cultivated mind, and of an age scarcely exceeding that of the Eastern Empress. Justinian was anuch impressed at the prospect of a princess of her rank placing herself under his protection, and he prepared a temporary establishment at Epidamnus, in a style suitable to her dignity, in anticipation of her being obliged to fly from the soil of Italy. Later on he expected to receive her at Constantinople, where he doubtless intended that she should be housed permanently in one of the palaces adjacent to the Court. This project, so grateful to the Emperor, was viewed with more than equal abhorrence by his consort. That Anala-

$$
1 \text { See p. } 550 .
$$




\section{The Age of Justinian and Theodora}

suntha, preeminent lig her hirth, her talents, and her beauty, would receive umemitting homage and admination from lustuian and his noblen, and eclipse the lempreas in her own halls, might be forexeen ats an incrituble result of such an urrangement. Whike this affair was under con. sieleration, and minh at any moment le realized, anonher wemm appeared on the secter, to whom the rivalyy of the Gothic quecen was at once ats odious as it threatened to become to Theodora hersetf. Gudelina, the wife of theo. elahad, participating in her hushand's elevation, assumed the attributes of regalty at the Court of Raremma, where she immediately found herself outshone hy her brilliant cousin, whose prerogatives and nerits were so much superior wher wwn. In instinctive alliance between the two women, the sting to whose vanitics was projected from the same source, was quictly formed. Iecters passed between them, calltiously exprensed, but elear to the mind of each: and Theodora infued some of her own determination inte the minet of the nominal queen in the 1 eest." The details of the pot which ensued are lost to us, and we can only xee that

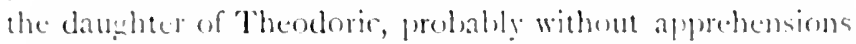
as regarels those for whom she had been the author of tostune, was ensmared by a coalition of her foes, and meler some specious prepense deported from her own eourt. By this consummation the Gothic dipue might, perhaps, have been appeared: hut the Empress was no adverate of half measures, and when l'eter departed on hin embassy to Karemat be was intusued by her with a seceret mandate to encomplase the death of Amalasmmba, lostead, therefore,

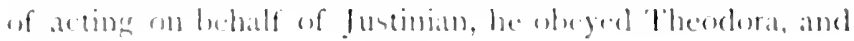

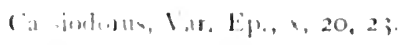




\section{Private Life in the Imperial Circle 6I1}

through his insidious counsels the unfortunate princess perished forthwith in her obscure prison. ${ }^{1}$

Hitherto Theodora and Antonina had pursued their respective courses at a distance from each other, but they were on convergent paths, which after the outbreak of the Gothic war necessarily became united. Although she had previously viewed her with dislike, the Empress now found that the wife of Belisarius was the only congenial agent she could employ for the furtherance of her underhand designs. Whether through policy or prejudice, Theodora had always been a zealous partisan of the Monophysite sect, and she was anxious to wring some concessions from the Catholics, which should conduce to the union of Christendom. To promote a willing instrument to the Papal chair was the leading move towards this end; and as a first step Silverius had to be removed to make room for such a pliable occupant. After the capture of Rome the opportunity occurred, and the commission was given to Antonina. By her artifices the Pope was accused of collusion with the Goths and

1 Procopius, De Bel. Goth., i, 4, with the elucidation in Anecd., I6, 24. In a letter from Gudelina to Theodora (Cassiod., loc. cit., 20), we find the statement, "Your remarks respecting a certain person have reached our ears with titillating effect (titillatio). Well, I may tell you that we are going to do what will please you." There is no plausible explanation of these sentences except that the two jealous women were plotting against Amalasuntha. Soon after (Ibid., 23) Gudelina again writes: "I am glad you approve of what has lately taken place in this Kingdom "; a palpable allusion to the death of the Queen. The lightest warning from Peter to the shuffling and scared Theodahad would have deterred him from any hostile act against his royal colleague; but he never spoke it, and, when the King affirmed that the murder was perpetrated withwut his linowledge or consent, it is most probable that he was stating a truth. It may be taken as certain, therefore, that the death-1hws wf Amalasuntha was aimerl from Byzantium. 


\section{I2 The Agc of. Justinian and Thoodora}

banished to the lonely isle of Palmaria. 'There shortly afterwards he encled his life at the hands of an assassin suborned by the same intriguant. By her address and success on this occasion Intomina concuered the farour of the Empress, who for the future deigned to mate use of her whencerer some objeet had to be attained by means of bold and deceitful assurance. Her skill in such diplomacy was soon to be tested in a more delicate enterprise.

On his restoration to office after the Nika riot John of Cappadocia attained to the summit of his power. He accummlated wealth to a prodigious amount, and at length his mind became inflated by the possession of vast resources to such an extent that be deemed nothing less than the purple to he an aderguate reward of his merit. He had recourse to soothsayers, who predicted for him the highest fortune he could desire; and he displayed himself to an expectant clement of the populace in dazaling apparel and surrounded by extraordinary state. 'To publish his importance to the utmost he went on a progress through the Orient, where he enthralled the vulgar by his magnificence, and appalled the soler-minded by the unserupulousness of his extortions. llaving fulfilled his purpose hy this expedition, he retumed to the capital, and made a trimmphal entry escorted, or rather borme along, by a pageant of female nudity, thinly. reiled by a diaphanous material which exposed more than it concealed of their beauties.'

Notwithstanding his singular talents and versatility in devising expedients, there was one relationship in which fohn showed himself to be olutuse and indiscreet in the highest degree. Orerpowered hy his own conceit, and feceling that the Emperor reposed molimited comfidence in him,

$$
\text { I1. L, dus, be .1.upi,lt, iii, e.t, elc. }
$$




\section{Private Life in the Imperial Circle 6I 3}

he was unable to appreciate the fact that Theodora exercised a boundless dominion over her husband. He, therefore, not only neglected to pay his court to the Empress, but, contemning and resenting her interference in affairs, met her with a hostile countenance, and even went so far as to asperse her in conversation with Justinian. Becoming fully aware of his sentiments towards her, Theodora soon came to hate him with an intensity she displayed towards no other member of the bureaucracy. His ruin was long uppermost in her thoughts, and she sought assiduously for some opportunity of killing him without incurring the odium of the deed. On his side the Cappadocian was keenly perceptive of the enmity he had kindled against himself in the breast of his Imperial mistress, and lived in continual dread of her murderous intent. Although he was encompassed by thousands of private guards, such as no Practorian Praefect had ever before maintained, and his palace was paraded by wakeful sentinels every hour of the day and night, he was unable to sleep without rising from time to time to explore with his eye every passage leading to his bedchamber, fearful lest some barbarian might be lurking in the dark ready at any instant to deal him his death-blow.

Such was the posture of affairs in relation to John until in the tenth year of his magistracy the inevitable catastrophe befell him. It was in 54r, when Belisarius left his wife behind him at Constantinople, that Theodora unbosomed herself to her confidential friend, as that lady had now become, ${ }^{1}$ as to her grievances against the insolent Praefect. The wile-weaving Antonina immediately evolved a plot to

1 On winning the favour of Theodora she received a Court appointment, viz., "Mistress of the Warilrobe," in modem phraseology" Coctinus, pp. 108, 125 . 


\section{1+ The Age of Justinian and Thiodora}

deliver her royal mistress from her pet aversion. Euphemia, an only child, was the daughter of the Cappadocian, and for her he cherished a deep affection. In sympathy with her fither, the girl alherred the Empress as the source of his disquictude: and would have welcomed eagrerly a change of sovereignty. Intuitis dy conscious of her sentiments, Antonima approached Euphemia with bandishments, and, by profesing a fellow feeling, soon captured her confidence. she bewailed the lot of her hushand, whose magnificent services had heen ill-requited by Justinian, and simulated a deme:mour of hopreless discontent. "But why, my dearest friend," exclaimed the girl, "when you have the remedy in your own hands, the devotion of the army, do you hesitate to redress your wrongs?" "In the camp," replied the temp. tress, "we could do nothing unless we had a powerful condjutur in the capital; but, were your father to join our party, we should doubtless effect what (iod wills with the greatest "ase." The Cappadocian was at nnce informed by his dugghter of all that had passed, and she expressed her belief in the sincerity of Antonina with warm enthusiasm. He was captivated by the brilliant susegestion, which seemed to him to signalice the providential fulfiment of the prophecies on which he relied. Ite, therefore, instructed Euphemia to prepare an interview between himself and Antonina for the following day, but lirst to extract from her an oath, in the form most sacred to the Christians, that sle wals acting in strirt geod faith. Antonima perjured herself without hesitation in the most impressive manner, but represented that an immediate colloguy in the city would be peribous. She, boweret, wath about to join ber hurband in the latst, and wembl halt on her way at their suburbun residence, where a

$$
\text { lincopilu, Inect, } 2 .
$$




\section{Private Life in the Imperial Circle 615}

mecting might take place without arousing suspicion. Hence it was agreed that on a certain date John should repair by night to the place indicated, where mutual pledges could be given and their plans matured for execution. Justinian was now quietly informed that John was engaged in a plot against the throne, whereupon he ordered Narses, with a company of guards, to be present at the meeting, in concealment. Should John be orerheard to utter anything treasonable, they were to rush in and cut him down on the spot. It the same time, such was his attachment to the man, he sent a secret emissary warning him to have no clandestine relations with Antonina. The caution was, however, disregarded by the ambitious conspirator; the interview took place, and he expressed his intentions clearly in the hearing of the eunuch. He was attacked forthwith by the soldiers, but his own guards, who had also been lying in wait, flew to his assistance, and in the scuffle which cnsued he made his escape. Had he even now sought the presence of the Emperor he could have saved his credit by some plausible explanation; but he acknowledged his guilt by hastening to take sanctuary in a church, and thus gave Theodora time to elaborate all her charges in due form.

A sentence of degradation and confiscation was now passed, and John was banished to Cyzicus, where, under the Gospel name of Peter, he was forcibly ordained as a cleric. A bishopric, however, he declined-criminals of lofty rank in that age were punished by being made bishops-still indulging himself in visions of restoration, and chose to remain in the unattached orders of the ministry. Shortly, in fact, he began to live in his old style of splendour, for Justinian had not exacted a rigorous surrender of ath his property, whilst he was also able to draw on large reserves which he had 


\section{The Ase' of Justinian and Thodora}

hidelen .aw:uy. Nevertheless further trials awailed him; an

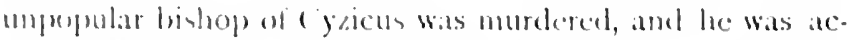
eused of the decel. A emminsion of semators repared to

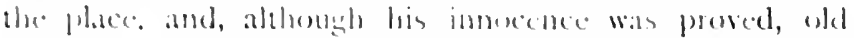
charges of fecoldation were raked alp, and in the end he was stripped af evergthing, and turned ent as a memdlo:ant with

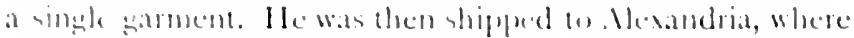

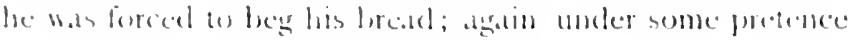

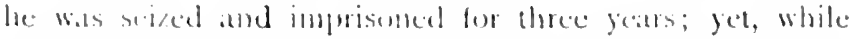
living a a vigrant. he olten had the andarity to toy and raise money hy chaming arreorages from delaulting dedans if the treasury.'

Ile are mow in a position to take up the thread of our marative as regards belisatus, whom we: left, in a state of mental distraction wer his wiles imenglarities, in Mesogen tamia. As somas he came nje with her he placed her under ghand in strict sechasion, divested of the homsoms dae to her

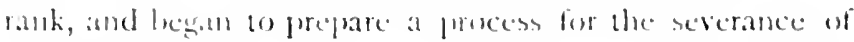
their eclatiomship for the future. liut he vacillated, pose

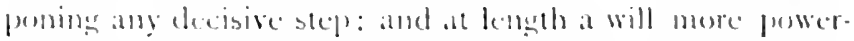
ful than his own intersenced to deprive him of all eption in the mater. The news of her comfindant's disgrace was

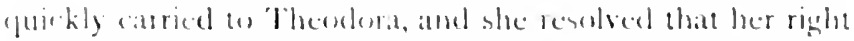
(1) do as she pleased should le smeleated in the most complete and effertual manner. . Ill her adversaries were arrested al a simgle couph, and licdisarius was commanded

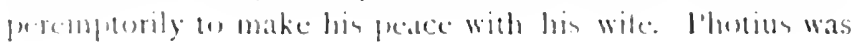

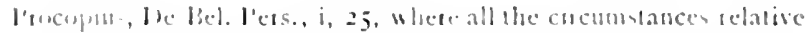

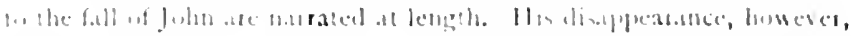

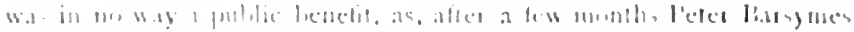

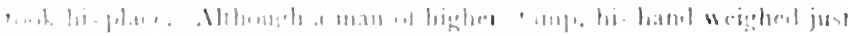

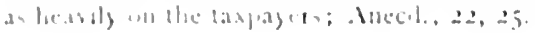




\section{Priate Life in the Imperial Circle 617}

seized and submitted to the torture, hut he kept his faith steadfastly, and refused to disclose where he had sequestered Theodosius. Theodora, however, put her agents on his track, and in no long time succeeded in unearthing him from his enforced obscurity. Only after several years of suffering did Photius escape from the prison he had been consigned to, and, making his way by secret paths to Jerusalem, at last freed himself from persecution by becoming a monk. ${ }^{1}$

In the autumn ( $54 \mathrm{~J}$ ) the Master of Soldiers and his wife returned to Constantinople, where the reception accorded to them at Court was in conformity with their respective merits in the eyes of Theodora. At the first convenient moment the Empress received her friend in private and addressed her: "Dearest Patrician Lady, a jewel fell into my hands the other day, the like of which no onc ever saw before; but, if you wish to see it, I shall be pleased to show it to you." Antonina begged effusively to be permitted to see the treasure; when Theodora, passing her hand behind a curtain which veiled the entrance to another apartment, led out 'Theodosius and presented him to his mistress. The raptures which ensued, and the expressions of gratitude bestowed by Antonina on her benefactress, surpassed description; but the reunion of the lovers was of brief duration. Theodosius, for whom the Empress was meditating great honours, was shortly afterwards seized with a dysentcry, and disappeared from the ranks of the living.

Much deeper humiliation, however, was in store for Beli-

1 Photius now disappears for ever from the pages of Procopius; but he turns up again in John Ephes. (Hist., p. 66, Smith), who says that, having taken the lonsure for some reason, he afterwards went up to Justinian in his monkish habit and received from him a military command in Syria, where he made himself obnoxiuns to the "orthodox" (Monoph.) by his harsh treatment of them. 


\section{Is The Ase of Jutinian and Thodora}

sarius. Nev year, when he was alesent with the army in the bast, a report wats spreatel that the limperor, esident in the plague-stricken capital, was himself in the threes of a fatal athack of the malady. The yuestion of the throne hecoming bacane was anximaly debated hy the geencrals, and seme of them nhered that, if the perple of constantinople procederl te elect a weressor, he shemld not hare the alleni-

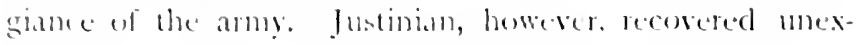
pertedly, and the attitute atepted hy the military rombil was divelgeed at court. Theodura was esperially enraged, an she assumed it to be part of hee prerogative, in the case of her husband's death, to nominate the hext orcupant of the throne.' When the sernerals returned to cinstintincople for the season, she instituted an infuiry. and ehose to see in Belisarius, though without prowe the leater of the culprits. She denoumed him in the hitterest terms to the Emperer. who was douldtess only too pleased at linding a fretex to sublue the exessive popularity of his eminent sulordinate. Ile was forthwith deprived of his post of General of the liast: his veteran guads, whe hat followed him into so mony louttes. were dividerl into pareels and assigned to various magnate's of the ('ourt, and his fortunes were seized for the lenedit of the lise. As a mere private ditien he might be sech daily walking dejectedly alone between his house and the ('ourt, where hewas a deved with nerglect and distarour. bue feared to absent himself lest a wote fate might befall him. In the meantime . Intonina enjeged the bighest foreur with the Empress, whilst the intercourse between humband and wife was of the coldest description. For several weets the greatt ineneral languished in the abject condition to which he had becn reduced,

$$
\text { S.C I. } 328 .
$$




\section{Private Life in the Imperial Circle 619}

although it appeared that his wife, being possessed of such powerful interest, should be regarded as the arbiter of his fate. On a certain day he left the palace, where he had been treated with such contumely, even by minions of low grade, that on the way home he glanced around involun. tarily, fearful lest assassins should be posted in some obscurity with a mandate to terminate his life. On his arrival he threw himself on his couch, despairing of any alleviation of his lot, while in an adjacent chamber he heard his wife's footsteps as she walked to and fro restlessly, under the influence apparently of some painful agitation. It was already dark when some one from without was heard demanding admission, and shortly an emissary was announced as the bearer of a despatch from the Empress. Belisarius shuddered and drew himself up, anticipating him to be the messenger of death. A letter was then presented to him, which he opened and read as follows: "You are not ignorant, my good sir, as to what your conduct has been towards us. But I am extremely indebted to your wife, and for her sake I pardon you, and make her a present of your life; look upon her as your saviour, and remember that our favour towards you in future shall be strictly measured by the amiability of your disposition towards her." A sudden revulsion of feeling was produced by the perusal of these words; he rushed to his wife and knelt before her. $\mathrm{He}$ kissed her feet and protested that he owed her everything; for the future she might call him her slave, and he should never again claim to control her as a husband.

After this crisis Theodora dealt definitely with the fortune of Belisarius, which he had amassed during his wars. His money and valuables were estimated to amount to six thousand pounds of gold ( $£_{240,000}$ ), and of this she made 


\section{The Asc of Justinian and Thiodora}

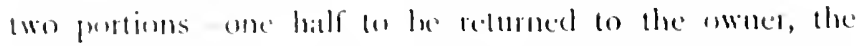
other she presented to the limperur. Jealous even of so much wealth remainimg in privale hands, sile now sought to rement a matriagc leetween a young relative of her own and loannina, the (m) child of lielisarius."

The seneral now petitioned to be reinstited in his military rank, in order that be might march against the l'ersians, hut Intonint protested that she would never agitin visit a country where she had heen subjected wo such outrageous trealment. He was appointed, llerefore, to the epuivecal positim of (innt of the Stables, which lett the rulers of his desting the option of employing him on any epportume service:

The sepucls of two episodes related in a previous portion of this work mat form a filting conclusion to the present

His name wits dnastasius, and he is represented an her grandern by

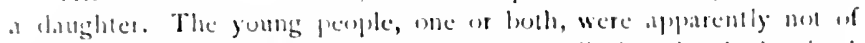
marriagcalile age, and so the welding wa put sit. but they had arrivel

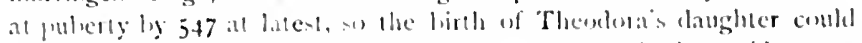

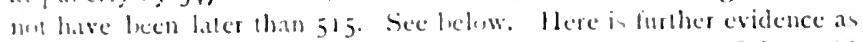

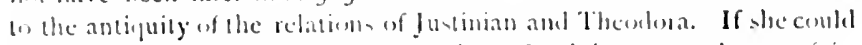

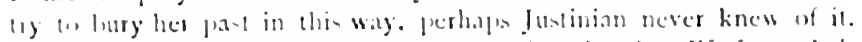

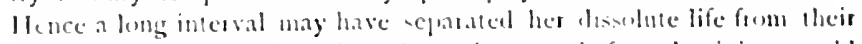

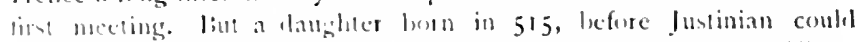

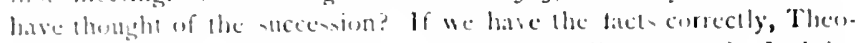

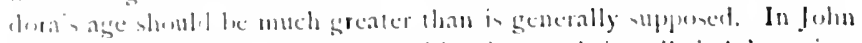

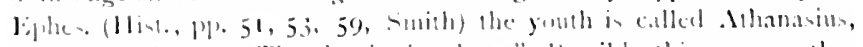

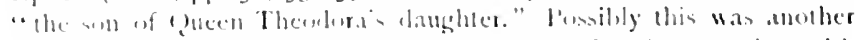

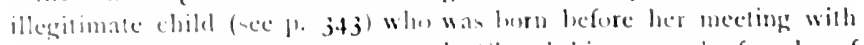

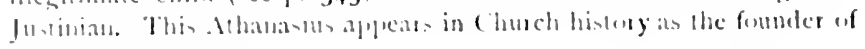
$\therefore$ peculiar licereny.

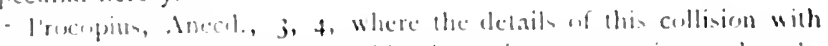

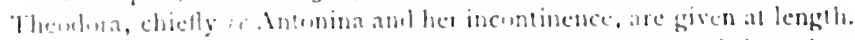

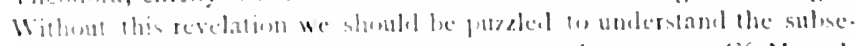

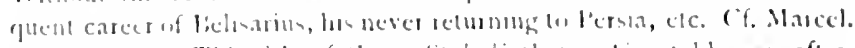

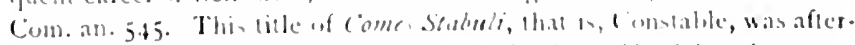

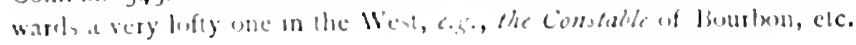




\section{Private Life in the Imperial Circle $62 \mathrm{I}$}

chapter. The first concerns the son of Theodora, who, as an infant, was apprehensively removed from the custody of his mother. In the remote province of Arabia the child grew up to manhood under the tutelage of his father, who watched with interest the career of his former mistress, but without revealing to the youth the secret of his birth. Being on his death-bed, however, he thought it right to communicate to him all the details as to his origin. After his father's decease, therefore, John set out for Constantinople, expecting that his mother would recognize his claims and provide for him accordingly. On his arrival he introduced himself among her servitors, stating plainly who he was, and awaited her pleasure. But Theodora was alarmed lest the knowledge of this amour and its result should come to the ears of Justinian, and determined that all trace of it should be effaced. Hence she received her son in strict privacy, and at once commended him to the attention of certain satellites of hers, who were generally regarded as the authors of unexplained disappearances. What method of suppression was adopted remained uncertain, but, whether alive or dead, nothing further was ever seen of this John.'

When Artabanes returned to Constantinople $(546)$ after his signal exploits at Carthage, he was received with great applause, and immediately promoted to the rank of Master of Soldiers at Court. He was much exalted by his good

1 Procopius, Anecd., I7. Procopius (Anecrl, I6) states that Theodora kept a number of spies, who reported all that was said about the Court in the public places and in private mansions. When she wisherl to get rid of some one of position secretly she had him seized late at night, and eonveyed, with his head veiled, on board a ship, by which he was carried to some distant place of emfinement. Siuch persons generally succumbed to harsh treatment, but occasionally obtained the forgiveness of the Empress and reappeared in society.

II. 


\section{The Age of Justinian and Theodora}

fortune, and especially at the prospect of marrying the Emperor's nicee, Prejecta, on whose account be had resigned his independent vicegerency of Africa. With the acquiescence of all parties, the brilliant nuptials were being prepared, when, at the last moment, an unexpected obstacle intervenced to shatter his impassioned hopes. A wife of his youthful days, long since repudiated and forgetten, still languished in his native land. In the times of his humble fortune she was indifferent to the relationship, but, learning by report of her busband s eminent success in the lisyantine service, she became eager to enjoy the benefit of his advancement. Abandoning Armenia, therefore, she arrived opportuncly in the captat, and hecame informed of the projected union which would exclude her for ever from his life. She presented herself at the l'alace with her sial story, and prayed for an audience of the limpress. Theodora, who always evinced a lively desire to act as the special providence of distressed women, readily granted her admission, and resulved to interfere on her behalf. She did so with her ustull effectivity, the imminent marriage was broken off, and the unwilling Artabanc's was forced to establish bis rejected consort in her conrentional position as the bead of his houschold. As for Prejecta, she was shortly comsoled with another partuer, and became the wife of John, son of the luckless l'ompeius, who had perished more than a dozen years before in the Nitia rebellion. But Artalunes was so exisperated that he was induced hy some malcontents of his

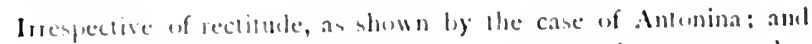

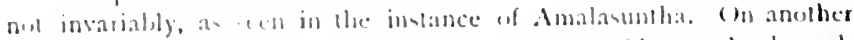

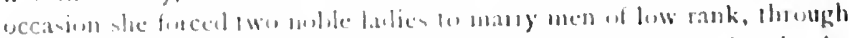

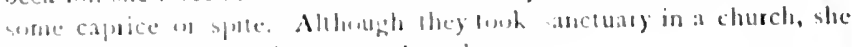

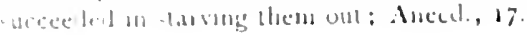




\section{Private Life in the Imperial Circle 623}

own nation to join a conspiracy which had for its object the assassination of Justinian and the elevation of Germanus to the throne.' 'The plot, however, was quickly betrayed, and proved such a complete fiasco, that, after a commission of the Senate had sat on the offenders and passed a nominal sentence, the Emperor lost all interest in the matter. ${ }^{2}$ Even Artabanes within a twelvemonth was lifted out of his disgrace and given an active appointment as Master of the Forces in Thrace. $^{3}$

${ }^{1}$ He married Matasuentha, widow of Vitigis, who died two or three years after his exile to CP.; Procopius, De Bel. Goth., iii, 39. Jordanes calls this a union of the Amalian and Anician families (De Reb. Get., Ix), which shows that this ridiculous adulation as to Justinian's pedigree was practically rife in the West.

2 Procopius, De Bel. Goth., iii, 31, 32.

${ }^{3} \quad l i i d ., 39$. 


\section{(HAPRER XIII}

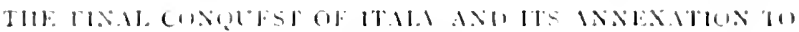
TII: EMIIII.

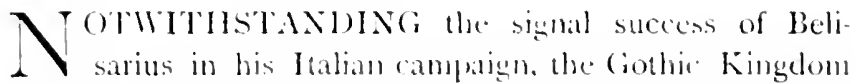
was cren further from lecing actually subjugalled to the ligantine power than was Africa affer the capture of (ictimer. The first care of Justinian was to appoint Alexander, an emineme logotheie, pepularly known as "the Sissors," to supervise the financial administration of the comber. His distinguishing sobnipuet had been acpuired through his remarkable dexterity in clipping round the gold t vin according to an ingenious methed of his own, which left the margin apparently intact. 'This moted extortioned desecnded on the Italians and sacked them mereilessly for suppositious debts, se that in a short time the public allegi ance was wholly alienated form the vietors. Lien the army

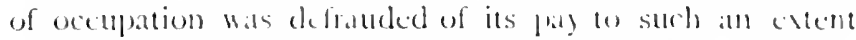
that the solelied began to view the hentile operations of the enemy with complete indiffer ner.'

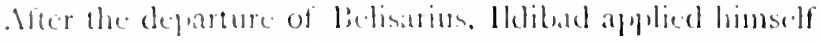
(1) revive the spirit of the remmonts of the conthie hares, and

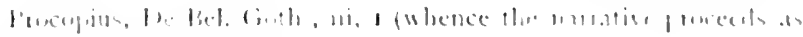
(bet. B). (1. Anect., 2.4, 26 . 


\section{The Final Conquest of Italy 625}

to attract to his standard all the malcontents among the Italians. He made Ticinum ${ }^{1}$ his headquarters, and soon found himself strong enough to join battle with the only Roman army which was willing to take the field. He defeated these troops with great slaughter, and was on the way to win a reputation in arms, when, as the result of a private feud, he was assassinated at a banquet. To him succeeded Eraric, but his elevation was displeasing to the Goths in general, and in a few months he also was killed insidiously to make room for Totila, a nephew of Ildibad.

Totila, or Baduela, ${ }^{2}$ the most illustrious King of the Goths in Italy after the great Theodoric, had already made his submission to Justinian, when the messengers arrived to offer him the crown of his nation. He was in command of Tarvisium, and explained to them candidly his position, but promised that, if they should take off Eraric by a certain day, before his truce expired, he would accept the sovereignty. The distasteful king disappeared; he was already a traitor, and had stated his price to the Emperor, and the election of Totila was unanimously ratified by the Goths (54I).

For many years Totila engaged himself in the reconquest of Italy, during which time he traversed the peninsula from north to south, and recovered nearly all the towns which had been lost to the Goths. The Byzantines failed to put an army into the field which could oppose him, and in two minor engagements they were defeated with considerable loss. The first blood was drawn at Faventia, whither Totila, in the year after his accession, hastened to meet the enemy. Ifis whole force amounted to five thousand men, the relics

1 Afterwards and now Pavia.

"Baduela on coins, but the Greeks always call him "Tótilas," perhaps phonetically. 
of two bundred thousand whom the Gothe had at their com manet cight years previously at the outset of the war. The kemans were twice as mumerous, and the batte was begun ly at single combat between . Irtablecs, an Armenian general of the Persian contingent transported from sisauramum, and a stremuens finth whe proposed himself as at champiom. The Irmentian was the victor, but received a fortuitous wound, which ultimately proved hatas. A general collision folluwed. when a skilfully posted ambush created at pamic among the by antines, who were dispersed with great camage and the loss of all their consigns.

The year after this success, 10 which was adled the cap ture of several towns and districts, Totila laid ejege to Naples. In seneral he adopted a peliey of elemency towards these communities which fell into his bands, a disposition which distrmed resistance, and often muth farilitined his pregress. Thus be appreached the Neapolitams with liberal promises, lut they were influened by the kom.m garrison to decline a surrender. A blockate was estalilished, therefore, in regular form. After some time, when the inhalbitints began to be severely pressed by famine, an antempl 10 raise the siege was made hy lemetries, a Master of soldicrs who had just anrived from constantinople. I few hundred infantry constituted his sole fore, but he endeavented to make the most of his slight resources by putting into sicily, and, while there, lowling a large number of frejght vesack with provisons.

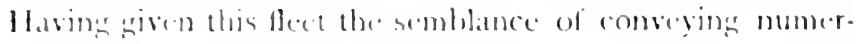
(me troope, he set silit for Naples, whereupen the smatl Gothic army were thrown into consternotion, beticving that he was athaneing against them with an werwhelunge forre.

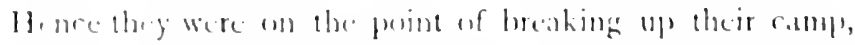
when be, not being reselute conough to puste the conterprise 


\section{The Final Conquest of Italy}

to a practical issue, declined from his course and steered for the port of Rome. There he essayed to transform the semblance into a reality by enlisting soldiers from among those who had crowded to the capital, where John, nephew of Vitalian, was in command. Their experience of the Goths, however, had lately been discouraging, wherefore they refused to associate theniselves to his expedition. He was obliged, therefore, to proceed to the relief of Naples without any increment of force. But in the meantime, Totila, having become cnlightened in the matter, posted a number of wargalleys in hiding, and attacked the provision ships as soon as a landing was attempted. All the vessels were taken, the crews were mostly captured or slain, whilst the residue, in cluding Demetrius, managed to escape in small boats. Later on, another effort was made, which was even more disastrous. $\Lambda$ newly-created Praetorian Praefect, in command of a considerable war fleet, manned by Thracians and Armenians, was despatched by Justinian to regulate the affairs of Italy. As a purely civil official he was incapable of maturing any plan of campaign, and, after wasting much time on the voyage, at length arrived at Sicily. Here he yielded to urgent pressure, and entrusted his forces to Denetrius, who again made sail for Naples. $\Lambda$ storm arose, however, and all the vessels were cast ashore in confusion in the vicinity of the Gothic camp, where they at once became the prey of the enemy. The general himself was taken prisoner, and inmediately utilized by Totila to bring about a surrender of the town. With a rope round his neck he was led before the walls and compelled to proclaim to the citizens that all hope of relief for them was at an end. Shortly afterwards the Gothic King himself came up and harangued a meeting of the Neapolitans to induce them to desist from their futile 


\section{The Age of Justinian and Thiodora}

renistance. He represented to them that on arcount of their determined defence anainst lielisarius be not only regarded them with no animosity, hut was cren grolteful for the loyaly they had shown on that occasion. lle besought them, therefore, to let him take peaceful possession, and to receive him as a friend whose intentions were wholly amicable. They asted for thirty days: he replied by granting them three months: but in a short time they surrendered voluntarily, glad to be relieved from the intolerable state of destitution to which they had been reduced. Fotila then arted with the greatest henignancy. The small byzantinc garrison were dismissed safe and sound, and even assisted with horses and supplies to enable them to make their way to kome. Is for the inhabitants, he was so solicitous about their health that he posted gruards at the gates to see that food stuffs were at first introduced sparingly, lest a sudden surfeit of the long-famished stomachs should engender a fatal illness thrunghout the city. His last procedure was to kevel the greatter part of the walls to the ground, a method of treatment he applied to all other strongholds when captured, in order to deprive the Byzantines of places of shelter from which they could safely cary on the warfare.

In those cases, howerer, where fotila considered severity (1) be expedient he showed hinself to be as relentess as the most tyrannical monarch. Thus, among his prisoners was one lemetrius, the commiscary of Xaples, whe during the siege had thought fit w provoke him ly the most unlicensed insult if loc came within carshot of the walls. This man he puninhed by cacising his tongue and amputating hoth his hande, after which inflirtion he set him all liberty. In another motance an tatian complaned to the King that his doughter had heen bavisted hy a ciothic guard, who hatp- 
pened to be a soldier of distinguished prowess. He was at once committed to custody, but his companions pleaded earnestly on his behalf. Thereupon Totila made them a speech in which he dwelt on the necessity for the Goths to adhere to the principles of rectitude and to maintain an honourable reputation among the people of the country. He also referred to the case of Theodahad, who by his iniquities had become the prime cause of the present war. Having persuaded his hearers by these arguments, he had the culprit executed, and assigned his possessions to the girl who had been outraged.

Totila now began to turn his attention to the recovery of the capital, and his first move towards that object was to address a letter to the Roman Senate with the view of predisposing their minds in his favour. He reproached them gently with having forgotten the generous treatment they had received at the hands of Theodoric and his successors, and contrasted the behaviour of the Byzantines since they had gained a footing in Italy with that of the Goths. At the moment, indeed, he was able to use as an object-lesson, not only the reinstituted financial oppression, but the conduct of the army of occupation, who were leading a dissolute life in the fortresses among prostitutes, whilst they pillaged the people of the neighbourhood without compunction for the supply of their wants. The King followed up this missive by causing agents who were in collusion with him in the city to post up notices full of liberal promises to the Roman citizens should they return to the Gothic allegiance. Whatever effect these overtures may have had on the minds of the Romans, they were not immediately fruitful to Totila, and the Byzantine garrison continued to retain a firm hold on the capital. 


\subsection{The Ane of I witinian and Theodora}

Net for another twelvemonth, however, was a Gothe encampment again secen before the walls of Rome (5.5); hut in the meantime 'Tenila had elaborated his preparations so as to remeler a siege effective to the utmost. Ly capturing the fortress of Tithur, situated on the . Inio. twenty miles to the nowtheast of the capital, he was enabled to command the Huviatile navigution and to prevent supplies reaching keme from the lielels of Puscany. On the other hand, by posting numerous wargalleys among the islands off the const, in the track of the com-ships which sailed from sicily, he cut off all pussibility of the Roman granaries being replenished ly sea-horne provisions. Bessas was now Eusermer of kome, but the garrison under his command amounted to only three thousand, and their ardour was soon dimped by the result of the lirst silly against the chemy. A hand of cioths approached the gates and drew upon themselves the attack of two eager lieutemants, who chased them in simulated flight until they fell into a skilfully-contrived ambush, from which few of them returned. After this mishap, which was incurred against the advice of bessas, no more sallies were made by the besieged.

Such was now the prosperous position of Totila's affairs. Yet a twelvemonth had already elapsed since Belisarius had received a commission from Justinian to go to the relief of laly. But he dismissed him to this command without resoutres from the state, telling him coldly that out of his own great wealth he was to provicte for the expenses of the cyertition. The (omblathe for such he is now te he called, travelled slowly through llyrioum and arrived at Saloma with four thousand recruits, whom while on his way he had inclue ed with difticulty to join his standarel. He now emlarked for lobla in 1stria, from whence after a short delay 


\section{The Final Conquest of Italy}

he arrived at Ravenna. At the former place he was met by a group of Gothic spies, who explored his camp and then returned to Totila with the report that his martial equipment was contemptible. They deceived the general by presenting a forged letter pleading for help on behalf of Bonus, the governor of Genoa, who was said to be in a sore strait. At Ravenna Belisarius issued a proclamation expressed in seductive terms, inviting Italians and Goths to join him, but his appeal met with no response, for the reputation of the Byzantines was at the lowest ebb throughout the country. From the time of his arrival at Pola he had begun to send out small bands both by land and sea to attempt something against the enemy, but success had generally been counterbalanced by disaster. He now decided to apply to the Emperor for assistance; and he intrusted his despatch to John, whose place at Rome he filled by transferring Bessas from Spoleto. His petition was conceived as follows: "Most puissant Prince, we have arrived in Italy, and, if nothing but the presence of Belisarius were necessary, the country would now be subjugated to your dominion. For here I am in the midst of the Italians-but without soldiers, horses, arms, or money. If such resources be requisite to carry on warfare it must be allowed that I am totally unprepared. As I passed through Thrace and Illyria I enlisted a few volunteers, but they are only raw recruits, who shun the enemy, desert their horses, and fling their arms on the ground. We have no money at command; the Coths have already collected whatever was due to us from the taxpayers. If I essay to address the soldiers my mouth is stopped by knowing that they are hungering after their pay; whilst numbers, who should be with us, have gone over to the enemy. I beg of you to send me my 


\section{$6_{32}$ The Ase of Justinian and Theodora}

veteran guards, and at the same time ats many troops of Huns and other harbarians as possible. Irunds also are urgently needed."

These representations produced no immodiate result, and nearly a year passed away helore the desired reinforcements began to arrive. In the meantime Belisarius had returned to Dalmatia, where he established his head-quarters at Epidammum. Ilis main olject was now to take action for the relief of Rome, but he seemed to have lost much of the energy and enterprise which fomerly characterized him. Is soon, howerer, as he had received an increment of force he sent two of his lieutenants to Portus, at the mouth of the Tiber, where a strong fort was still held by the Byzantines. From thence, with the co-operation of bessas, they were to assail the (ioths, both parties acting simultaneously from opposite sides. 'They made two attacks, in accordance with their instructions, but nothing could more bessas to emerge from his shelter: and on the second occasion the Goths, having been forewarned, caught them in an ambush with a fatal result to almost the whole band, including the leaders.

so far military assistance had failed, but an effort to re. provision the capital was now made from another quarter. Vigilius, the Roman Pontiff, was at the moment staying in Sirily, where he possessed large estates. He, therefore, freighted a tlect of corn-ships and direrted them to sail up the Tiber by the way of lortus. But while they were still a long distance off their approach was signalled to the (ioths, who thereupon came down in effective force and concealed themselves near the mouth of the river. The movement was olserved by the garrison of the fort, who at once elimbed to the highest points of the battlements, and by waving of hauds and grmments tried to warn the conroy off. 'The ships' 


\section{The Final Conquest of Italy'}

crews, however, mistook the gesticulations and imagined that their advent was being hailed with rejoicings, wherefore they redoubled their energies in order to complete the voyage. Hence they steered straight into the ambuscade of barbarians and were all captured without a chance of being rescued. Among the prisoners was a bishop, whom Totila relieved of both his hands, as the penalty of answering falsely to his interrogations.

At the beginning of the next year $(546)$ the Romans were hard pressed by famine, and began to debate the advisability of surrender. As a preliminary they sent an enroy to Totila to ask for a short truce on condition that if succour did not arrive in the interval they would give themselves up. Pelagius, the chosen deputy, was a man who acted a considerable part on the ecclesiastical stage, and was already well known to Justinian, at whose Court he had resided for several years as Papal legate. The Gothic king received him warmly, but interrupted him, as he was about to begin his exhortation, in order to enter on a justification of himself. First he warned Pelagius that there were three things which it would be useless for him to solicit, viz., clemency towards the Sicilians, to spare the walls of Rome, or to deliver up fugitives who had joined his army. He went on to picture the happy state of Sicily when the Goths first conquered the peninsula, abounding in wealth through the splendid fertility of its soil, and able to export copious supplies for the sustenance of Rome. At the prayer of the Romans Theodoric had left the island almost ungarrisoned, lest the inhabitants should be disturbed in their peaceful occupations to the detriment of the capital. Yet when a small Byzantine force landed they were received everywhere with open arms and the island was allowed to become a 


\section{3+ The Age of . Instimian and Theodora}

base for the imasion of It:ly. As for Rome itself, the Cirecks had shut themselves up there and harassed the (ioths by artifices and stratagens without ever daring to march out and meet them farly in batte. The citiens, he adeded. would profit by the destruction of those walls which were the canse of their being reduced to destitution while the hostile armies were intent on their schemes of attack and defence. In reply to this haranguc Pelagius merely protested that he had not been permitted to deliver his message, and, on his return to the city, declared that he had found the king in too impracticalile a mood to be infuenced by any entreaties.

The Romans now felt desperate and approached Bessas and his staff with supplications that he would either provide them with food, turn them out of the city, or at least end their sufferings by killing them at once. His only answer was a recommendation to contain themselves for the present, as belisarius would soon be at hand with an army of relief. Thus the reign of famine was prolonged until the last stages of stariation were reached. Money and every kind of property were sacrificed to huy any residuc of corn that could be discovered or the meanest description of animal fool. When horses, degs, and mice were consumed, the people took to feeding on netlles, which grew in profusion among ruins and around the inner circuit of the walls. leaths and suicides from the unlearable distress were of frepuent oncurrence. Nevertheless the garrison was fairly nourished, for Bessas had stored a large yuantity of grain in well-guaded granaries, from which he not only mantained his men, but sold portions regularly to the richer citizens. Thus be kepo on amassing wealth all a rapid rate, and was unwilling that the siege shoukl be raised ats hong as his 


\section{The Final Conquest of Italy}

lucrative trade continued. In the direst extremity some citizens purchased from the soldiers the right to escape, for the last payment they were able to make; and, ultimately, large numbers ware turned adrift to perish by the wayside or to be seized and slain by the Goths.

By this time Belisarius, having been joined at Epidamnum by as many troops as he saw any prospect of obtaining, determined to proceed with all his force against Totila. John had at last returned, ${ }^{\mathrm{t}}$ and with him he concerted his measures of transit and attack. The former, with a portion of the army, was to land at Hydruntum, ${ }^{2}$ and make his way northwards with Rome as his objective; while the Constable, with the bulk of the troops, was to sail round the peninsula, and make a descent on the enemy from the waters adjacent to the capital. As for the part played by John in this campaign, it may be dismissed at once by saying that after landing he carried on a desultory warfare in southern Italy, made marches and counter-marches through being impeded by the enemy, but never arrived within striking distance of Rome. ${ }^{3}$ Belisarius, however, soon achieved his proposed voyage, and appeared at the mouth of the Tiber, where he at once began offensive operations against the Goths. One of his first steps was to relieve himself of the delicate charge of his wife, and to have her guarded in a place of safety. He, therefore, consigned her to the fortress of Portus, under the charge of one of his

${ }^{2} \mathrm{He}$ had delayed at $\mathrm{Cl}$ '. to celebrate his nuptials with the daughter of Germanus; Procopius, loc. cit., I 2.

${ }^{2}$ Now Otranto, the nearest point to the opposite coast of Greece.

${ }^{3}$ He was really afraid to be in the vicinity of Antonina, says I'rocopius (Anecd., 5), as he believed that she had a mandate from Theorlora to make away with him, the latter having an inveterate enmity against Germanus and his family. 


\section{The As"e of Justinian and Theodora}

licutenants mamed Isaac, whom he enjoined to devote all his attention to shielding her from harm. "Renain at your post," said he, "cren should you hear that I am slain."

'The most pressing necessity was now to revictual Rome, and this belisarius essiyed to do by carrying a fleet of provision ships up the 'liber. Ile had at his disposal two humelred wargalleys, which he loaded with foodstuffs and also epuiped most effectively with a view to forcing a passage. lohus on the forecastle of earh vessel he constructed a wooden himark after the puttern of mual battlements, from the shelter of which his marines could safely discharge their darts. Is Totila had foreseen that such attempts would be make he had long taken measures to render them incffectual. Across the river, at a narrow part about three miles up, he had rased an obstruction in the form of a wooden hridge, att earhend of which on the bank he built a large tower, also of timber. In addition chains were used to close the passage over the water farther down. With a view to assailing this structure the Roman general joined together laterally two of his ressels, and on them he erected a tower. high enongh to overtop those constructed hy the Coths at the sides of the stream. I boat filled with combustihles, piteh, sulphur, resin, was placed on the summit of the tower: and this falric be caused to be navigated in ad. vance of his flotilla. His spare casalyy and infantry he drew ne ne the river lank near the sea; and he motified Bessas to make a diversion hy sallying forth anel assaulting simultanerusly the cinthir camp.

Everyhing prospered as had heen inteneled: the chains

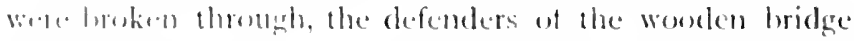
were severely smiten hy the arows which were showered

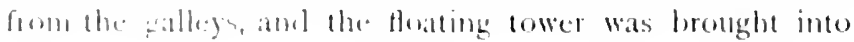




\section{The Final Conquest of Italy}

close contact with the obstructive barrier. Then the boat was set alight and launched on to the top of one of the enemy's towers, which took fire and was consumed with two hundred of its occupants. One detail only of the mancuvres failed of accomplishment; Bessas never moved, wholly engrossed as he was with his mercenary avidity.

Suddenly, when success appeared to have been almost attained, the operations were abandoned and Belisarius drew off his forces without attempting to push his advantage. Intonina, though unwittingly, was the cause of this disastrous collapse. While the assault was proceeding a glowing account of the victorious progress of the Byzantines was brought to Portus, whereupon Isaac, inflamed with ardour, collected a hundred cavalry, and made a dash for a section of the Gothic army which was encamped near Ostia. At first the enemy were dispersed, but they shortly rallied, and, recognizing the paucity of their adversaries, charged them, with the result that many were slain, while Isaac and some others were captured. A few, however, escaped, who rode full speed to Belisarius and informed him that Isaac was taken prisoner. The general, without stopping to inquire, immediately sounded the signals of retreat, and made all haste to Portus, concluding that his wife had fallen into the hands of the Goths. There he learned the true details as to the temerity of Isaac, which affected him so deeply that he became seriously ill, and was incapacitated for some time from taking the field. Such was the last effort to save Rome from being retaken by the Goths, and before long Totila succeeded in making himself master of the city.

Nothing could have been more languid and ill organized than the defence of Rome under Bessas. The garrison lost all sense of discipline, no strict watch was kept, and the

II. T T 
efficers rarely went on their rounds to see that the sentinels remained awate at their posts. Under these circumstances four Isaurians, who were on guard at the Asimarim gate, conceived the possibility of making their fortumes. ( hoosing a quiet hour of the night, they let themselves down the wall by ropes, and paid a visit to the barbarian king in his camp. There they explained to him with what facility they were able to pais in and out, and proffered to introduce cothic coldiers in the same manner. He promised liberally, hut distrusted his informants and sent hack two of his men to put the matter to the proof. 'They passed in and reported favourably, but still 'lotila hesitated, suspecting a stratagem. I few nights later the Isaurians retumed and made the same representations, whereupon the King repeated the cxperiment by the agency of two other spies. 'They also untered the city, and explored the reasibility of the scheme, hut Totila delayed taking any decisive step. The question, however, was talked over in the Gothic camp, and soon after a koman patrol, coming on a group of the enemy loitering near the walls, seized them and brought them before Bessas. On leing examined they confessed that they had hopes of the rity lecing betrityed by some I saurians, but he dismissed their statement as being not worth considering. fin the third time the traitors approarbed l'otila, and he now sent two officers of his staff, in whom he reposed the unmest contidence, to investigate the proposal. On their contirming the previous reports he decided to at.

() ne crening after nightfall letila got all his men under arms, and marched in silence to the Asimarian gate. Four Goths, selected for their strength and courage, surmounted th. wall he meiths of lopes let down to them by the lsantians. Insinle they attacked the gate with axes, and cut 


\section{The Final Conquest of Italy}

away all the woodwork in which the locks and bolts were fixed. The portal was then thrown open, and the King entered with his troops. Still apprehensive of some deception, he drew them up in close order in the nearest open space and waited for daylight. Insensibiy a report as to what had happened spread through the city, upon which the garrison crowded to Bessas, and all fled through one of the opposite gates. Of the citizens a few nobles and about five hundred of the proletariat were all that remained within the walls; and these, emaciated by famine, dragged themselves with difficulty to take refuge in the churches. As soon as morning broke the Goths laid aside their suspicions and began to scour the streets, when a few soldiers, who had remained, and about threescore civilians, fell victims to their rage. Totila wended his way to the church of St. Peter, with the intention of offering up a thanksgiving, and was met on the threshold by Pelagius, who adjured him by the Gospels which he held in his hand, to spare the Romans. "Still a suppliant, Pelagius!" exclaimed the King. "Yes," replied the priest, "since God has made me your servant."

The victor now issued his commands to stay all further massacre, but, with reservations as to his own share, permitted his soldiers to spoil the houses. Much wealth came into his hands from the palaces of the nobles, and especially the immense treasures accunulated by Bessas as the gains of his nefarious traffic. Such poverty now prevailed at Rome that members of the noblest families might be seen in mean apparel begging their bread through the streets from the enemy. Among these was Rusticiana, the daughter of Symmachus and widow of Boethius, who had expended all she possessed in relieving the indigent. Some time previously she purchased from the Byzantine rulers at a great 


\section{o.po The lge of Justimian and Theodora}

pice the privilege of anelthewing the statues of 'Theodoric in revenge for his having esecuted her father and hushand.' The foths would mo have retaliated, hat Totila saved her from their hands, and also restrained them from violating any of the females found in the city.

The day after the capture the (iothe king comsend his forces, and preached them a sermon on the advantages of chical conduct in warfare. Ile pointed ent to them that in the first campaign, although numerous and rich, they had succumbed to seven thousand (ireeks, hecuse they shrunk from no exesses and committed everyerime that secmed expedient at the moment. Sow, however, through adhering to the principles of rectitude, although diminished to a mere handful with slight resources, they had trimpled wer wenty thousand of the cnemy. Te also addressed the Romans in the same sense as his former despatch and proclamations, reproaching them for their ingratitude to the foths, and again expressing his amazement at their incliscretion and pre. judice in preferring the oppressive rule of the byantines.

Totila's next procedure was to send a legation, of whom lelagius was the chict, to solicit an equitable peace from Justintan. They were the bearers of a letter in which he prajed for a restoration of the amicable relitions which had furated between . Inastisius and Theodorie: but they also hat verbal instructions to threaten the total destruction of kome, the massacre of the semate, and a Gothic imvasion of Illyricum. In respense the Emperor did not enter into any newestiations, but merely indicated that Belisarius was his phenipotentiary, throwgh whom only he was willing to treat.

When this answer was enmeyed to 'Tetila, he resolved to rase: Rome to the ground, and transform the area into a is... $1.5 \%$. 


\section{The Final Conquest of Italy}

sheep pasture; after which he planned a march into Southern Italy against John, who had lately inflicted some damage on the Gothic forces in that region. He began by ruining the walls, of which he had levelled about a third part of the circumference, when he rcceived an expostulation from Belisarius, who had been apprised of his design. "Men of wisdom," wrote the general, "have always been characterized by the desire to build great cities, but to ruin them can only be described as the work of fools. Rome, by reason of its extent and magnificence, is the most excellent of all the cities of the earth; built gradually in the course of many ages by a long series of emperors, with the assistance of numerous architects and artificers; the realization of immense resources brought together from every part of the workd. bestroy this splendid creation, and you will incur eternal obloquy in the memory of suceeding generations. But pause and reflect that the issue of this war must be one of two events: either you conquer or are defeated. In the first case you will find that the injury is your own, and you have demolished the proudest ormament of your kingdom. In the second you have aroused the just resentment of the victor, and can expect no clemency at his hands." Totila was persuaded by these arguments, and reframed from doing any further damage to the capital. The Senators, however, he placed under guard in his camp as hostages, and the residue of the inhabitants he deported into Campania. He then removed from the neighbourhood to inspect the progress of his affairs in other parts of Italy. Rome was thus left wholly deserted.'

'In a later part of his work, however, Procopius says (loc. cit,, iv, 33) that Totila also lumt many of the hulldings at this time. Narcellinus Com. (an. 547) corroborates, and says that for forty days there was neither man nor beast within the city. 


\section{6.t2 The Age of Justinian and Thiodora}

As soon as belisarius heard of the departure of 'Totila, he determined to re-ocupy the racant caphial. lle lrought all his men mp form l'ortur, fherefore, and set them to work in rebuilding in a temperary lashion the numed stretehes of wall. The stomes, which lay scattered aremol, were onllected

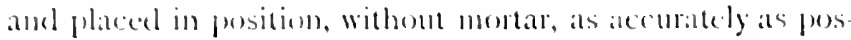
sible: stakes were planted outsiele: the fosse wats cleared: and the adjucent grousd was plentifully sown with calthrops. In there weets the work was completed, and, before long, many of the kemans, eiger to acemp their old demiciles, returned, for whom the gonerat latel up a coppous store of provisions. When l'onila heard of this procedure, he was much amnoyed, and hastened labck with all specel to recalpture the cily. The coths deliseded several assaluls, hut were imariably repmlsed with loss, motwithstanding thatt they had tom down and destroyed all the soltes, which had, therefore, to be defended by hodies of men pacted in the open passages. secing no proypect of suceess, the (inthic King som redised with his army, from whom be hatel to condure many reproaches for not hasing abloped more ffective measures to render Rome untemalike. In his retreat on this ocasion be destroged all the brighes ower the liber except the Milvian. lielisarius now fitted newgatles to the city and again went through the form of sending the key to fustinian.

l)uring the aseat year $(5.77)$ the hostile armies frequently came into collision, hut mo decisive suceess was went. In 5.18 belisarius tecongized that the penimsula could wot be complered without muln greater forces than he had at command, fut Iustinian appreated to be lukewarm in the matter, and the contingents he despatehed from timk to time were

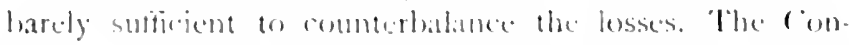
stoble resulved, therefore, we send his wife on a special 


\section{The Final Conquest of Italy}

mission to Constantinople, hoping that, if she brought the question before the Empress, her exceptional influence might obtain for him the needed reinforcements. Antonina arrived at the Imperial capital, but only to learn that the Augusta had died a few weeks previously, whilst Justinian was immersed in theological studies to such an extent that his administrative energy had completely deserted him. She acted, therefore, on the alternative, which doubtless had been proposed by her husband, and petitioned the Emperor for his recall. Her request was readily granted, and thus terminated the second campaign of five years which Belisarius had conducted in Italy. This time he returned home without martial honour, but with a considerable accretion of wealth, which he had exacted with little scruple from the Italians, according to the usual practice of the age, whenever an opportunity offered.'

After the departure of Belisarius, Totila breathed more freely, and determined to devote all his energies to the recovery of Rome. During the last year of his stay the Constable, by hovering around Southern Italy with his fleet, had confined the attention of the Gothic King to that quarter,

'Procopius, De Bel. Goth., iii, 35; Anecl., 5. Ile left Italy this time as in surreptitious flight, glad to abanton his task. In this year (548), Procopius tells us (De Bel. Goth., iii, 29), the great whale Porphyrio (see p. 36S) was found stranded near the mouth of the Euxine. It hat got into shallow water, too eager in its pursuit of dolphins. The measurements were 45 by i 5 feet, luut some doubted it to be the same animal as had been known in the Propontis for fifty years. Procopius does not, however, mention the "wonderful dog," who visited CP. in 530, and runs through all the Chroniclers from Jn. Malata to Zonaras. Rings and coins placed in a heap on the ground he restored to their owners, or fetched accorling to their value correctly. Ite also indicated to order among the bystanders pregnant women, brothel-keepers, lawis, adulterers, misers, and benevolent persons. 


\section{4t The Age of Justimian and Theodora}

while the capital had been committed to the charge of an excellent soldier named biogenes, with a garrison of three thousand picked men. Early in 549 the third sicge of Rome by the Goths was legun, but the city was now well provisioned, and the gorernor vigilant, so that for several months the enemy made no sensible progress. There was still, however, among the defenders a hand of Isaurians, to whom was entrusted the custody of a gate on the south, that named after the . Apostle l'aul; and they also conceived the iclea of betraying their charge to Totila. As the reward of their treachery, they saw some of their former commades abounding in weath, whilst the arrears of pay due to the byzantine army already extended over screral years. 'They' opened up communications, therefore, with the king: and in collusion with the traitors a plan of capture was soon ayreed upon. But the circumstances were now very different, and an elaborate scheme had to he devised in order to attain to the same result. Success, however, was made commensurate with the greater complication of cletail. The Tiher was now entirely at the command of Totila, as he had recently taken the fortress of Portus; whilst the only stronghold in the ricinity still held by the Romans was Centumcellace, a sea-port nearly forty miles to the north. Ilaving posted a strong ambush on the road to the latter place, the king led the bulk of his forces secretly in the lirst watch of the night to the neighbourhood of the gate in question. At the same time he instructed two hoats carrying trumpeters to row (quietly up the river, and, as soon as they arrived at the morth wall of the city, to begin sounding their instruments with all their force.' Everything turned ont as had

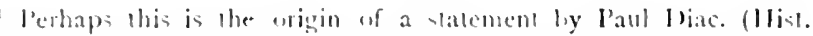

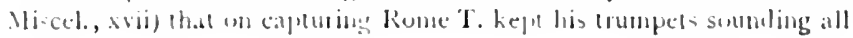




\section{The Final Conquest of Italy}

been anticipated; when the garrison heard the blast of the trumpets, all rushed to the proximity of the Aurelian gate, thinking that a surprise assault was being delivered on that side. Thus the Isaurians were left in sole charge of the gate of St. Paul, which they immediately opened for the admission of the Gothic army. The news quickly circulated that the enemy were within the walls, with the usual consequence of panic and flight by those gates which were remote from the vicinity of the hostile troops. Centumcellate was the destination of most of the fugitives, where they expected to find a safe retreat, but on the way they fell into the ambuscade set by Totila, so that almost all perished. Four hundred of the garrison, however, fortified themselves in the tomb of Hadrian and nearly as many took refuge in the churches, but they were soon induced by Totila's liberal promises to give themselves up. A majority of them even took service with his forces.

Totila now did all in his power to restore Rome to its pristine splendour, as he had lately been taunted by 'Theodebert with not being the actual sorereign of Italy, since his capital, besides being held by the Greeks, was partly in ruins. He had sought an alliance with the Franks through marriage with one of the King's daughters, and on these grounds the hand of the princess had been refused to him. Hence he re-established a Senate composed of Italians and Goths, and tried to repatriate as many as possible of the inhabitants who had been scattered in various directions.

night to warn the citizens to take sanctuary from his turbulent soldiery. "He lived among the Romans," says that historian, "like a father with his sons." (The same passage occurs in Lib. Pontif., Tigilius.) "The teaching of St. Benedict," he adds, "had moulded his character to this clemency." 


\section{6+6 The Age of Justimian and Theodora}

At this period the Gothic King again attempted to comprese a peace with fustinian, hut his onctures were treated with unconcers. It is probahte that all this juncture the Emperes woukd have heen willing a ratify a dreaty, hut be had at his side an atriner who trged him persistemtly not (1) absuden laty to the dominion of the dian heretics. l'upe ligilius had leen for a couple of years resident at the ligantime (inut, and, as the represemative of Orthodox laty, he eould by no means endure that the l'apsl seat should be under the comtrol of the foths. Cictmanus was, therefore, appointed to he commander-in-chief, but he dicel (m) his way through lly ricmon, and for the next wo gears the wat eomtinted to le waged by land and sea on the same indecinive lines. The principal exploit of Totila was the recomquest of sicily, lut he left it incomplete: and shomly afterwards Artabunes virtually recovered the island for the Empire.

In the autum of the year $55 \mathrm{r}$, a naval batte off Anconit, disistrous to the (ioths, again induced lintila to approach the Emperor with peace proposals, hut Justinian remained obdurate, and seemed to te persessed with a rooted prejudice against entering into any consention with the (ioths. The name had become odious to him, and, after so many jears of guasi-occupation of Italy, he doubetess looked on that nation merely as heretic rebels who disturbed the peace in an integral part of his dominions.

In this naval engagement, the only express conflict on the water in this century, the kombus were provided with fifty Watrships of the utmost capacity, the (ioths with forty-screa.'

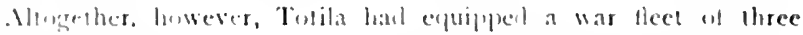

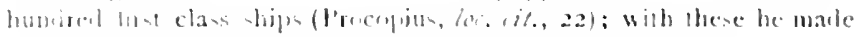

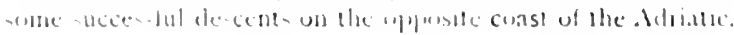




\section{The Final Conquest of Italy'}

John was in chief command on the side of the Romans, Indulfus, a renegade officer of Belisarius, on that of the Goths. The fight was begun with great ardour on both sides, and conducted as nearly as possible in the form of a battle on land. A cloud of arrows was interchanged by the hostile crews, and then the ships were impelled against each other in order to facilitate the use of swords and spears. The Byzantine fleet, however, was manned by sailors who were skilful in manceurring their ressels, but the barbarians, not being a maritime nation, could not dispose of crews who were versed in nautical evolutions. On the one side the ships were navigated methodically and kept in just array, while on the other they were urged indiscriminately to the attack. Certain groups of the Gothic fleet were marshalled with an excessive interspace, and among these the Romans drove in, isolating the vessels, and easily sinking them by their combined action. In other positions the ships of the barbarians were packed together so closely that they hampered each other's progress and checked the use of the oars; and in such cases their efforts were perverted into a contest to regain their freedom of movement. Hence the battle resulted in thirty-six vessels being destroyed by the Byzantines, whilst the remaining eleven escaped to the shore, where they were burnt to save them from the enemy. The preservation of Ancona for the Empire was the immediate result of this victory.'

After the death of Germanus the Emperor decided to appoint Narses to the command of the war in Italy, although the eunuch was now a very old man, and, according to

1 These Italian campaigns had evidently caused the liyzantines to develop their naval power, and caused a reversal of the state of things which prevailed at the beginning of the Vandal war. See p. 503. 


\section{6.tS The Age of Justinian and Theodora}

cridence which cannot he isnored, probably almust an octo. gemarian.' We are also told that he was short of stature and slightly huilt, lut mentally strenuens and decisive in character to a remarkable dewere: As soon as the equestion was

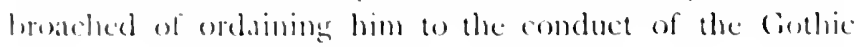

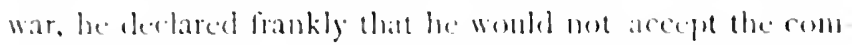
mingom unless he were granted resourres adepuatle to the mangutude of the enterprise. Justinian yichled, with the result that an imbasion of Italy wats phonned hy the cunueh on a scalle which was a revelation to thoss habitnated to the fitful am partial elforts of the last doeen years. Not only did he levg an ammy commensurate with the undertaking, lut he insisted on being provided with fomds to liquiclate the areass due to the half-heared troops whe had lan.

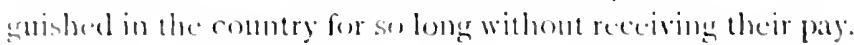

Narses set ont for Italy in 551 , but le was delayed on his rente by an eruption of the Huns, which it Wats no pan of his duly to arrest. He established a campl, thercfore, at Jhilippepolis, and waited calmly until the barbarians has divideal into two streams, one of which bore destruction to Thessalemina, and the other in the direction of the metres.

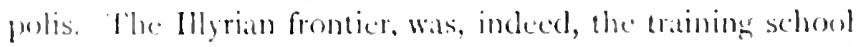

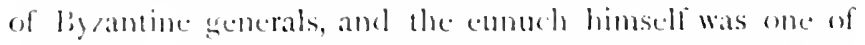
those who hat often been engaged in the tank of resinting

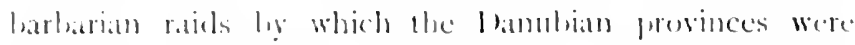
combinually pillaged and depopulated. Ilis mogress was abo impueded amewhat ly a defeciency in the commissariat, which arose from a combey of provision ships having heen

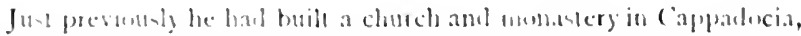

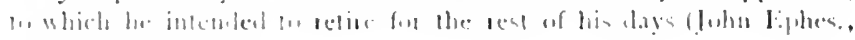

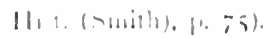

- Isthita, i, 16. 
captured in the Adriatic, previous to the battle of Anconit, by Totila's fleet. Early in 552, however, he was able to concentrate all his forces at Salona, where the rital problem of transit into Italy began to be discussed. Besides a numerous Byzantine army of the conventional type, he had been joined by fully ten thousand barbarian auxiliaries from tribes not regularly drawn upon, as Foederati for the Imperial Service. Lombards, Herules, Huns, and Gepaeds crowded to his standard, and he even disposed of a considerable Persian contingent led by Cavades, the real or reputed grandson of the late Shahinshah. ${ }^{1}$ All those who made a profession of arms among the Byzantines or their allies, both officers of rank and private soldiers, were eager to take part in this expedition; the one class attracted by the Illustrious dignity held by Narses at Court, the other by the munificence displayed by him towards the armies he had commanded, and because of the benignancy of his personal bearing among the troops. ${ }^{2}$

Totila, on his side, had not been idle, but had made himself well acquainted with the extent of the hostile preparations which were impending against him, and he, therefore, employed every means that foresight could devise to render the invasion of his kingdom difficult and dangerous. He knew that the prime objective of the Byzantine general would be Ravenna, but he had ascertained that he did not possess such a fleet of transports as could convey the whole army at once across the Ionic Gulf. Should the

\footnotetext{
1 Sce P. 415.

2 This campaign of Narses occupies the latter part of the fourth book of the Gothic War of Procopius. More than the first half of that book is devoted to Persian affairs, and would properly be called the third book of the Persian War.
} 


\section{The Ase of Justimian and Theodord}

ampls, howeser, soll by defolments, he expected to be she to eut off the sepratrate brigates when they were in the at of disembathing. (In the ather hand, should Narses elect to mareh hy land, it was meressary for him to round the heal of the Adratic seat and purste his route along the

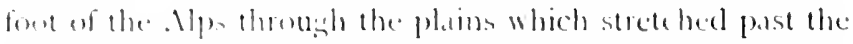
city of Viroma. The the latter distriet, therefore, he sent his

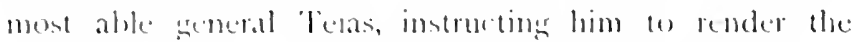

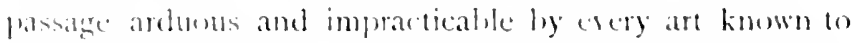

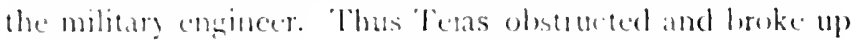
the ground in the vicinity of the lo in all comediable ways. ther a widels of several miles trees were felled and strewn in the pattes of aceess, hroad and deep trenches were excarated, precipitous guldes were detred, and extensive areas were hollowed out, into which water and mud were allowed (1) run from adjacent streams. On the proximate side of this rulely diversified barrier the (iothic general awaited the byantine army, to attack them with his troops should they venture to pass.

llaving determined to march overland, Sarses advanced with his army from sialona to the north of Istria, where he halted on the horder of the Venetian territory. Under the semblane of a fricully pact with the coths, the franks, still cheribing the design of extending the it dominions, were in occupation of 'lransparane laly in its whole breadth. I recent legation from the bimperor to win them over an allies against Totile hat failed: and, if the Byzantines were an pass by the roube of Veromed without being

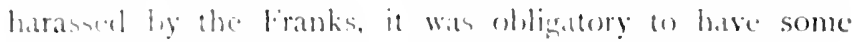

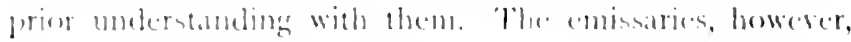
ent ly Narses le the generals of that nation recturned with a specious refusel, but at the same time informants arrised 
who made him aware that the permission, if granted, would have been futile owing to the obstructive dispositions of Teïas. A military council was now held; there was still a third way of entering the peninsula, which Totila had left unguarded, beset as it was by obstacles which seemed to preclude the passage of an army. By proceeding along the coast they would be secure from hostile interruption, but the land line was irregular, marshy, and broken by numerous estuaries of navigable rivers. By the advice of John, however, whose experience of a decade in the country qualified him to act as guide, this seeningly impassable route was undertaken and successfully accomplished. All the available ships and boats followed the army close to the shore; and by means of them, as often as the mouth of a river was reached, a floating bridge was improvised, over which the troops passed in safety.

After Narses arrived at Ravenna he gave the whole army a nine days' rest, during which time he received a further accession of strength through being joined by all the Byzantine detachments remaining in that region. ${ }^{1}$ Just as the work of recuperation was completed the Gothic governor of Ariminum, Usdrilas by name, taking umbrage at his apparent inactivity, addressed him a sharp, provocative letter. "After filling all Italy with rumours of the terrible host of barbarians, which you are bringing against us," said he, "you now stay loitering behind the walls of Ravenna. Come out at once and show your spirit to the Goths; no longer tantalize us, who are eager to meet you in the field." The eunuch smiled at the bravado of the Goth, and shortly

1 It will be observel that Ravenna was never captured unless by stratagem. Both Theodoric (p. 545) and Belisarius (p. $5 \mathrm{SI}$ ) entered by a pretended treaty with the occupants. 


\section{The Age of Justimian and Theodora}

afterwards resumed his mareh with all his forces. The first skirmish with the enemy occurred at the crossing of a small stream near Ariminum, from whence Usditas came out at the head of a troop of horse: and the Romans were elated by the haplyy omen, as they considered it, of the boastful Guth heing slain in this encomnter. Nirses now pushed onwards with all speed, having the Flaminian llay on his left, and began to move through the Apemnines towards the fickls of Tuscany.

In the meantime Totila, having effected a junction with 'leras in the vicinity of Rome, pressed forward to meet the invaders at a distance as far as possible from the capital. As soon, however, as news was lrought in of their rapid progress, he called a halt and pitched his camp near the village of laginae, among the western slopes of the $\Lambda$ pennines. ${ }^{3}$ before long the approach of the byzantine army was signalled; and when Narses found himself within a dozen miles of the enemy's camp he sent forward his legates with an invitation to the Gothic king to surrender peacefully, representing to him that he could not hope to resist the whole force of the Roman Empire. Is an ulterior proposal. should they fincl him resolved to fight, he was to be asted to name a day of battle. Being admitted to an audience they submitted the preseribed offer, to which Fotilat replied angrily that he would accept no terms, hut that they must prepare for a conflict. Thereupon the legates at once propounded the repuest: "Appoint a time then, good lord, to decide the matter by arms." "On the eighth day from the present," said the King, and dismissed his interrogators.

1 "Taginac lies just below the central waterhed of the Dpennines, near the modern ciublio" (Oman, of. etf., f. 32). 
On receiving this response Narses immediately began to instruct his line of battle, anticipating that Totila would advance to the attack without delay, in the hope of finding him unprepared. Nor was he deceived, for on the following day the whole Gothic army poured into the neighbourhood and drew themselves up not farther than a couple of bowshots from his own position. The site of hostilities was a small plain surrounded by eminences, which were popularly supposed to be the sepulchral mounds of a Gallic host who had been slaughtered here by Camillus in the early years of the Republic. Hence the place was named the "Graves of the Gauls." Close to the Roman army on the left was a low hill, which protected them from being assailed directly on that flank, but which, if held by the enemy, might become the source of a deadly play of darts. The night was tempestuous, and, while it was yet dark, the eunuch sent a squad of fifty infantry to occupy this elevation. Directly day broke Totila saw the advantage which had been gained, and determined to dislodge the occupants. A troop of cavalry were sent against them, but what with the adverse slope, the discharge of arrows, the spear thrusts, and the clashing of shields, which terrified the horses, the Goths could make no headway, and had to retire discomfited. A second, and a third time, Totila urged a similar attack, but nothing could overcome the strenuous resistance offered by the Byzantines, and at length he had to desist from his efforts.

The time of the main battle was now at hand, and on each side the generals delivered an exhortation to their troops. Narses lauded the superiority of his own men and spoke of the enemy with contempt, asserting them to be mostly renegades from the Imperial service, whose best

II. 


\section{5t The Age of Justinian and Thoodora}

prospect was to perish while making a desperate onslaught. 'Totila encouraged his army by impressing on them that this was the critical day of the war, and by a present victory they would irretrievably crush the power of the Emperor. As for the forces opposed to them he pointed out that they were only mercenary barbarians, who would be chary of risking their personal safety merely in exchange for the high pay by which they had been allured.

Both armies were now marshalled orer against each other in a long and deep array. Narses collected all his barbarian auxiliaries, with whom he was unfamiliar, into the centre, and made them stand dismounted from their horses. The flower of the Roman troops he placed in the wings, four thousand foot-archers in front, and belind them fifteen hundred cavalry in each division. On the opposite side the Goths were ranged in two lines, all their caralry being in front and the infantry behind. The two generals now rode along their respective battle fronts, uttering words of encouragement; and Narses added the objective stimulus of rich jewels, armlets, necklets, and golden chains, displayed aloft on the points of spears, and promised the bestowal of them as the rewards of valour. As in most cases, there was a single combat in the interspace, the champions this time being a Roman renegade and an Arnenian, when the triumph of the latter infused an access of confidence into the Imperial troops. Totila, however, was anxious for a short delay, as he was awaiting the advent of two thousand horse, whose approach had just been intimated to him. In the meantime he essayed to divert the attention of the enemy by exhibiting his address in equitation and play of arms. He was dressed with regal magnificence, and his weapons and armour were resplendent with gold. Purple 


\section{The Final Conquest of Italy}

plumes flowed from his helmet and lance, and he was mounted on a charger of faultless proportions. He began to caracole along the front of his line, wheeling his horse in circles and pulling him up short at one instant or another to turn in a different direction. Simultaneously his spear was tossed into the air and caught dexterously with interchanging hands, now by one part, now by another. In this saltatory exercise he frittered away the whole forenoon; and then he sent a herald to ask for a parley with Narses. The eunuch, however, replied that it was mere trifling for him to propose a debate on the field, which he had declined at the fitting time.

It was now announced to Totila that the expected accession of cavalry had arrived, whereupon he retired to his tent and passed the word for his troops to fall out and partake of their midday meal. With a swift change, however, all returned to their ranks, and the Gothic cavalry at once began an impetuous charge against the enemy, thinking to catch them in disorder. But Narses had suspected a ruse, and therefore had restrained his men from breaking into loose order or laying aside any part of their equipment. At the same time, lest they should suffer by fasting, he caused them to be served with refreshments while standing in line with their eyes fixed on the movements of the enemy. As soon as he perceived in what manner the battle had begun, the Roman general executed an evolution which was fatally adverse to the chances of the attacking troops. The wings were signalled to deploy towards the centre, and thus in a moment the Byzantine army assumed a crescentic formation, which embraced the Gothic cavalry between its extended horns. From each side the four thousand archers poured their arrows into the dense squadrons of horse, who 


\section{The Age of Iustinian and Theodora}

by some strange perversity or misjudgment had been ordered to rely solely on their spears and the force of their charge to overthrow the ranks of the enemy. A small proportion only of the Guthic horsemen succeeded in reaching the Roman line, most of them falling or becoming disabled the moment they entered the deacly interspace between the two lites. Nevertheless they maintained their efforts with temacity till the dectine of day, when the Byzantine army by a umanimous impulse began to move forwards against them in firm array. Gradually the Coths were pushed backwards, becoming more and more disordered as they retreated, until they again came in contact with their own infantry. In proportion as the enemy yielded the ardour of the Romans had become inflamed; men of all arms attacked fiercely, and soon the retreat became a rout; whilst the Cothic infantry, secing the defeat of their main force, attempted no defence, but fled wherever the way seemed to lie open for escape. Six thousand of the Goths were slain on the field, and, in addition, a large number of the Imperial troops, who, during the last decade, had from time to time deserted to their standard."

The life and fortunes of Totila were forfeited on the day of Taginae, but the mode of death of the Gothic King is wrapped in some uncertainty. At the outset of the battle, according to one account, a chance arrow pierced him with a mortal wound, and compelled his removal from the field. After his departure, the (joths engaged the enemy without tactical direction, and failed through being deprived of his skifful supervision. Another version relates that as soon as

1 Founding on Theophanes, an. 6044, and cielsenus, i, p. 659, this battle must have been fought in July, or at latest the beginning of August. 


\section{The Final Conquest of Italy}

the catastrophe was complete he fled through the darkness with a few followers, when he received a lance-thrust from the hand of a barbarian, who was unaware that he had struck the King. Whatever may have been the immediate cause of the fatality, it seems certain that on that night he arrived at Caprae, about ten miles from the scene of the battle, in a dying state. There he shortly expired and was buried by his companions, who at once left the neighbourhood. Soon afterwards a Gothic woman, resident on the spot, who had seen the occurrence, told some Roman soldiers that the King was dead, and indicated to them his grave. Disbelieving her story, they disinterred the body and found that she had spoken the truth. ${ }^{1}$ Before they restored the corpse to the earth they stripped it of its regal apparel, which they brought to Narses. He, in his turn, forwarded the spoils to Justinian." Such was the inglorious end of the reign of Totila, whose martial talents and civil magnanimity deserved a better fate; and we would fain believe that version of his death which elucidates by an inevitable mischance the infelicitous result of this ill-conducted battle so unworthy of his previous reputation.

Narses now marched on Rome, receiving on his way the submission of several towns which had been taken and retaken during the present war. At the same time the rem. nant of the Goths mustered at Ticinum, which Totila had fortified as the repository of his treasure in North Italy, and there they immediately elected Teias as King. When the eunuch arrived before the capital, he found the Gothic garrison prepared to offer a vigorous resistance; but their dis-

'Procopius (loc. cit., iv. 32) gives both stories of his death, the first vaguely, the second, which he appears to believe, circumstantially.

${ }^{2}$ Jn. Malala, xviii, p. 486; Theophanes, loc. cit. 


\section{The Age of Iustimian and Thoodora}

positions were unskilful, and they were far from being able to foresee the various possibilities of capture. The siege, therefore, was of brief duration, and they were shortly circumvented by a simple strategical ruse. Three simultaneous assaults were made on distant portions of the wall; and the defenders allowed their attention to be concentrated on these points, whilst leaving the rest of the wide circuit vacant. 'Then Narses, seizing a favourable moment, ordered one of his lieutenants named Dagisthaeus, supported by a strong brigade, to make a sudden attempt with scaling ladders on one of the deserted stretches of wall. 'They ascended, meeting with no obstruction, gates were thrown open, and the Imperial standard was displayed from the battlements; whereupon the (ioths abandoned the defence and saved themselves by every available outlet.' 'Thus for the fifth time in less than a score of years was Rome captured by one or other of the contending mations; and again on this, the third occasion, the Emperor had the gratification of receiving the keys of the city from one of his generals.

let the subjugation of Italy was still far from complete; and an arduous task had still to be executed by Narses before he could proclaim the peaceful settlement of the ruined Gothic kingdom to be an accomplished fact. Desperate bands of Gothic marauders now pervaded the country and wreaked their vengeance uncontrolled on the Italians for the ill-success of their arms. All the Roman senators

I'rocopius (De Bel. Goth., ir. 33) notes a curious parallel between the carcers of Dagisthaens and liessas. The latter, as we hase seen, diegraced himself al kome, and subequently elistinguished himself by the capture of l'etra (j, 601). But just lefore bagisthaens had been depored under arrest from Jazica, where be had held the command, on the charge of accepting tribes from the lersians. He now retrieved his disgrace by the capture of liome. 


\section{The Final Conquest of Italy'}

were murdered in Campania, where for their own safety they had been located by Totila; and even at Ticinum a band of hostages, selected from the noblest families, were slaughtered by order of the new Gothic King. And Teïas, notwithstanding his limited resources, was not in the least inclined to make his submission to the victorious eunuch, but determined to oppose him to the last by every means in his power. First, he tried to win the alliance of Theodebald, who had lately succeeded his father on the throne of the Franks, but that monarch declined to identify himself with a failing cause.

The prime object of contention between the hostile generals was now the city of Cumae in Campania, where Totila had deposited the richest complement of his treasures and on that account provided it with a strong garrison. At first John was sent into Tuscany to obstruct the avenues of approach from the north; but Teïas eluded his vigilance, and, by pursuing devious and unfrequented paths in the vicinity of the Adriatic coast, penetrated into Campania before the Byzantines had become aware of his escape. There he fortified his camp on the distal side of Mount Vesuvius, close to the Bay of Naples. The position chosen by the Goths was the south side of a bridge over the Draco, a small river flowing between steep banks, impassable even for infantry. On this spot they built wooden towers and constructed military engines, by means of which, owing to the difficulty of access, they were able to withstand the efforts of the whole Roman army for two months. With their fleet in proximity they held the command of the sea, so that they suffered from no lack of provisions. At the end of that time, however, the ships were betrayed to the encmy by a traitorous Goth who was in charge of them, and thus 


\section{The Age of Justinian and Theodora}

their supplies were cut off. They now took refuge on the Lactarian Mount, which rises from the ridge of land separating the Bay of Naples from that of Salemo. Here they soon found themselves in danger of being starved out, and resolved, therefore, to make a desperate effort to regain their frecelom. Lnexpectedty they came down on foot in a solid mass, and threw themselves on the Byzantine troops. Teias, in the forefront of the battle, performed prodigies of valour, and soon became the central aim for his adversaries. A dozen spears became fixed in his shield, so that he could no longer wield it freely to shelter himself. He called loudly for his armour-bearer, and an attempt to exchange it was made, but for a moment his body remained unprotected and he received a fatal wound. Nerertheless, his men fought on till night terminated the conflict. At the dawn of day the fight was resumed, and again persevered in till night. At last they sent a cleputation to Narses, proposing that they should be allowed to possess themselves of whatever funds they had deposited at their homes in various parts of the country, upon which they would leave Italy to go and live according to their own laws among other barbarians. Following the counsel of John, Narses made a comvention to that effect; whereupon the Goths agreed to surrender all their remaining strongholds and to evacuate the peninsula.'

Such was the end of the dominion of the Ostrogoths in Italy, but Narses still had a considerable war to wage, partly owing to the convention not being strictly carricel out, but chiefly because the Franks were fimly convinced that they

This is the last scene in the historical work of Procupius. Agathias now lakes up the narrative and hegins with an epitome of his prede. cesen. In his first and second leoks he treats of the further wasfure of Narses. 
could make themselves masters of Italy. Their resources were great, but for more than a decade they had been witnesses of the successful resistance offered by Totila with his small army to the anxious efforts of the Emperor; and hence they were itching to find a plausible pretext for invading the country in force. Theodebald was a feeble youth, evidently tottering to the grave, and two nobles of his court, the brothers Leuthar and Butilin, professed to rule both the King and the nation. As soon, therefore, as it became patent that the power of the Goths in Italy was irretrievably shattered, they affected to be moved by the prayers of a few refugees of that people, who had dwelt in the Transpadane region, and had not been directly concerned in the compact with Narses. Hence they quickly levied an army of over seventy thousand men, and suddenly appeared in North Italy under the semblance of being zealous allies of the Goths, but in reality because they believed the country to be without a master. The Roman general had not yet received the submission of Cumae, whilst some thousands of Gothic soldiers had fortified themselves at Compsae under a bellicose Hunnish leader, named Ragnaris; but on hearing of the Frankish invasion he abandoned his operations against them, and marched into Tuscany. Here he stayed to accept the capitulation of a number of towns, but sent on the greater part of his forces to block the way of the invaders on the southern bank of the Po. Some slight successes were obtained, but the eunuch was really incapable of opposing the Frankish host, and he soon retired to the shelter of Ravenna for the winter (553). Italy was now virtually lost again to the Empire had the barbarians who invaded it been capable of organizing a government or founding an administration. But to indulge themselves in rapine was the only 
course that was intelligible to them, and they possessed the country as brigands, not as civilized conquerors. 'The bulk of their army was, in fact, composed of German tribes, who had not yet been converted to Christianity. Even the Goths recognized shortly that they had nothing to hope for from such allies; and before long, Aligernus, the brother of Teias, journeyed voluntarily to the north and presented himself before Narses with the keys of Cumae in his hand.

It the first flush of spring Leuthar and Butilin roused themselves to prosecute their raid, and made a rapid and destructive march through Central Italy until they arrived on the south of Rome. The brothers now divided their forces, and, while one half carried their ravages down to the Sicilian strait, the other devastated the eastern tract of the peninsula until they were brought up by the waters of the Mediterranean. The churches were broken into and rifled of all their precious ormaments by the heathen Germans, but the Orthodox Franks abstained scrupulously from any such sacrilege. 'The summer was already at its height, when communication was reopened between the Frankish leaders: and Leuthar announced his decision to return home forth. with in order to enjoy the fruits of the expedition. He exhorted his brother to follow his example, and not stake the rich spoils of Italy on the doubtful event of a war with the Romans. Between Butilin and the Goths, however, a bond had been executed in precise terms, by which it was pre. arranged that, should he succeed in ousting the Byzantines, be should become their king. He, therefore, remained in Campania, whilst his brother proceeded to retrace his steps to the north. On the way a foreguard of three thousand men fell into an ambush, contrived by Artabanes at Fanum, 


\section{The Final Conquest of Italy $66_{3}$}

with disastrous results, but the main army continued its march unopposed, crossed the Po, and pitched their camp at Ceneta, in Venetia. Here they bewailed the loss of much of their booty on the long route, and gave themselves up to a life of indolence and relaxation in compensation for their protracted predatory exertions. Soon, however, a pestilence invaded the camp, emanating doubtless from an ill-ordered commissariat and defective sanitation, by which most of them perished, including Leuthar himself.

As for Butilin and the moiety of the host which remained with him, they also succumbed to disease in considerable numbers. The plenteous supply of grapes in Campania induced them to indulge too freely in a raw wine of their own concoction, and hence many of them fell victims to a fatal flux from the bowels. Since Butilin hoped to obtain a permanent seat in the country, he decided to fortify himself in a strong position, and await the development of events. At Casilinum, ' on the river Vulturnus, he found a suitable spot, and there he fixed his camp within an enclosure strongly fenced by wagons and stakes. Their front was defended by the river, and wooden towers which they built at the foot of an adjoining bridge. His army amounted to about thirty thousand men, and he was also expecting reinforcements which had been promised by his brother as soon as he had deposited his treasures in a place of safety.

Narses now thought himself strong enough to meet the diminished host of Franks in the field; and he therefore came down from the north and encamped on the other side of the river, almost in sight of the enemy. His whole force,

1 Modem Capua, the ancient town, retaining its name, having been moved to this site. 


\subsection{The Age of Justmian and Theodora}

howerer, did not exceed eighteen thousand men, a great many of the barbarians, who had accompanied him into Italy, having been dismissed to their homes shortly after the defeat of Totila. He began hostilities by cutting off the foraging parties, on which the Franks were dependent for supplics, a proceeding which harassed them so much that they decided to end the molestation by a battle. When the Koman gencral noticed that the enemy were preparing to attack him he disposed his forces in order, placing all his infantry in the centre, and his cavalry on the wings. $A$ certain number of his troops who were armed only with missiles, bowmen, and slingers, he posted at the rear, and he also concealed a detachment of horse in an adjacent wood. The martial equipment of the army opposed to him was very incomplete. All were infantry who bore no defensive armour, except shields and an occasional helmet; and their only offensive weapons were a sword, a barbed javelin, and a two-edged axe. 'They drew themselves up in the form of a wedge with the apex in front, and when the order to charge was given they drove down on the Roman centre with an impetus which carried them right through the troops opposed to them, so that they seemed to be on the way to capture the camp of their adversaries. Narses now signalled for his wings to wheel round towards the centre, until they faced almost the reverse way, and then to empty their quivers into the unprotected backs of the enemy. At the same time they were assailed in front by a brigade of Herules who had not arrived at their place in the centre before the sudden onslaught of the liranks. The result of these tactics was the practical ammihilation of the barbarian host, along with whom Butilin himself perished. While most of them were slain and many driven into the river, it 


\section{The Final Conquest of Italy}

is said that only five escaped death on the field of battle. Of the Romans only eighty were killed, and these were the men who stood in the ranks where they had to withstand the first shock of the Frankish charge. Shortly after this victory Narses proceeded to the reduction of Compsae, where the number of recalcitrant Goths, who had taken asylum with Ragnaris, now amounted to seven thousand. The fortress was blockaded during the winter; and at the beginning of spring (555), after their leader had been slain in a chance encounter, the occupants surrendered unconditionally to the eunuch, who sent them to Constantinople, so that their services might be utilized for the future in the defence of the Empire.

After a war of twenty years Justinian at last felt himself to be the veritable sovereign of Italy; and he drew up forthwith a comprehensive Act for the future government of the country. The title of this document, the legate to whose hand it was entrusted, and the place chosen for its promulgation, were all worthy of its importance. In the autumn of 554 the exiled Pope Vigilius quitted the Imperial capital to annunciate the Pragmatic Sanction-from the throne of St. Peter as the Emperor's message of amity to the Italian people. Yet the concessions made to the inhabitants by this Constitution were, perhaps, not worthy of the name; and many who benefited, through the adoption of a definite Imperial policy, did so at the expense of others. Not altogether in. equitably, however, as the main object of the Emperor was to restore the status quo before the accession to power of Totila. The Pragmatic Sanction, therefore, enacted a universal reinstatement of, and restitution to those who were

1 Apparently a town near the Aufidus, on the northern border of Lucania. 


\section{The Ager of Justinian and Theodora}

the losers by the interior administration of that monarch. In his efforts to consolidate his power he had made, or winked at, sweeping transfers of real and personal estate to his supporters from those who were disaffected to his cause. Now everyone was called on to take his own again wherever he could find it, without being troubled to make out his claim in conformity with the niceties of legal practice, it being conceded that there might have been an indefinite loss or destruction of instruments of title during the general upset. Lands and cattle, houses and movables were to revert to their original owners; slaves of both sexes, who had obtained or assumed their frecdom in the laxity of the times, were to return to the hand of their masters; and even the marriage tie was declared to be a nullity if contracted under the altered social conditions. Thus, husbands and wives who relapsed into servitude could be repudiated by their hymeneal partners: and even nuns, who had tasted or matrimony, had the option of re-entering their convents. On the other hand, Justinian did not encroach on the liberty of his new subjects by depriving them of advantages which they had formerly enjoyed: for instance, the provincial Rectors were to be chosen locally by the prelates of the Church from among the Italians themselves; and the salaries customarily paid at kome for the promotion of liberal studies, literature, rhetoric, law, and physic, were to be continued to the professors. He also invited the Roman senators to visit him at the Byzantine Court whenever it pleased them to do so; and enacted that travellers might pass without let or hindrance between Italy and the rest of the Empire. The usual formulas as to the efficient collection of the taxes and against fiscal oppression were, of course, prominently expressed in this Constitution; and in this de- 
partment we may be sure that the Gothic rule was often regretted. ${ }^{1}$

1 The Pragmatic Sanction is found at the end of all editions of the Corpus Juris Civilis. In the affix Narses is named as the Praepositus of the Sacred Cubicle, that is Grand Chamberlain, or Chief Eunuch, the title under which he became military governor of Italy. He was provided with a Praetorian Praefect. There is a fragment of a later Act in which $\mathrm{J}$. legalizes a composition pro rata between debtors and creditors, having regard to the losses caused by the Frankish invasion. 


\section{CIIMPLE NIV}

REIGION IX TIE SIXTH CENTLKS: JUTIXIXN AS I THEOLOGIAN

7 HE reign of Iustinian in its theological aspect was a 1 long contest between the I)yophysites, that is, the Orthodox Christians according to the creed of the dominant hierarchy, and the Monophysites. Although the Emperor was derotedly attached to Orthodoxy, he was above all things desirous of finding some common ground on which the conllicting sects could meet and be reconciled. from the opposite side Theodora was animated ly a similar policy; she warmly espoused the Monophysite doctrine, but was equally anxious with her husband to promote a general union of the Christian Church. The Monophysites at this time were divided into wo parties, vis, the uncompromising dcephali, who would conrede nothing, and those who atccepied the Itenoticon of Zemo $(182)$. The former, almost all Egyptians, anathematized the ('ouncil of (halcedon; the latter, chiefly Asiatics, pretended to tolerate that synod with the reservations expressed by the Henoticon.' 'Thus, in the

1 The gist of the llenoticon was that all heing develed adlecemts of the Nicene Council, they repuliated anything wheh wan in contlicl with its decisiuns, whether promulgated "at Chatcedon or elsenbere"; Evagtiu, iii, 1.4. 
East there was a partial agreement between the Orthodox and Monophysites; but the Christians in the West were as uncompromisingly Orthodox as the Acephali in Egypt were dissident: the Patriarch Acacius, the author of the Henoticon, had been excommunicated for that piece of work by the contemporary Pope, Felix. ${ }^{1}$

After the death of Anastasius, the hierarchies of Rome and Constantinople had resumed friendly relations, owing to the policy adopted by Justin and Justinian of persecuting the Monophysites; " but under the influence of Theodora, or because of the Emperor's discouragement at the results of these harsh measures, the opening of the new reign wore a much more benign aspect toward the heretics. Amicable discussion of the points of controversy and mutual concession became the prevalent sertiment of the Court; and soon Monophysites of every grade in the priestly office began to crowd into the capital. Justinian received them with condescension and Theodora afforded them material hospitality; finding them quarters according to their rank in the house of Hormisdas and even in the Imperial palace. ${ }^{3}$ The Emperor argued questions of doctrine with them as a prelate might do with his inferior clergy, and convened representative meetings of both parties with a view to the resolution of differences. ${ }^{+}$His success, howerer, was limited to the addition of one of the less contestable formulas of the

${ }^{1}$ Concil. (Labbe, Mansi, I759, etc.), vii, I053; Theophanes, an. 5980.

${ }^{2}$ The correspondence letween Juslin and Justinian and the Ioly See of Rome (Baronius, Concil,, Migne) has lately been re-edited in Script. Eccles. Lat., Vienna, I 895 , xxxr, from the Arellana Collection.

${ }^{3}$ John Ephes. Comm. de Beat. Or. (Laud, etc.), pp. I27, 154.

- Concil., viii, 818 et seq. The Collatio consisted of five or six lishops of each side. They were convened by Strategius, Count of the Sacred II. 


\section{The Age of Justinian and Theodora}

Monophysites to the Catholic theology, viz, that "God was crucified for us," "but this step did not meet with universal or permanent approbation." Yet Theodora was able to push her influence to such an extent that she procured the translation of Anthimus, Bishop of Trebizond, who was known to have heretical leanings, to the Patriarchate of Constantinople (535). ${ }^{3}$ This appointment was such a triumph for the dissident sect that they assumed their advent to power to be actually realized; and the recognized leader of the Monophysites, Severus, the deposed Bishop of Antioch, who had previously repulsed Justinian's advances as being illusory, now issued from his retreat and appeared among the dependents of the Byzantine Court.'

This ascendancy, however, rested on no solid ecclesi-

Largesses, who said they were called together, not under lmperial conpulsion, but as in response to a "paternal and priestly exhortation." Afterwards they were met by Juslinian, who invited them into llormisdas, where he addressed them "with Davidian kindness, Mosaic patience, and Apostolic clemency."

'Cod. I, i, 6; cf. Facundus Defens. i, I.

2 Albrogated by Council of 692, can. S1. Al this lime (533) J. addressed several letters to the Church and the pullic laying down the lines of Orthodoxy (Crid. I, i, 5-S).

3 .Marcel. Com., an. 535: Theophanes, an. 6029, etc.

1 Zachariah $11 y t .$, ix, 16, 19; letters paned between Inthimus and the Monyphysite leaders, in which he aceepred the Ilenoticon, "enacterl to annul the Council of Chalcedon and the impious "Tome of leo " (ititl, 2I-26). The latter was the document which decided the rule of faith at Chalcerton. In it l'ope Leo 1 demonstrated the lwo natures of lesus from the Gospels. Thus when he performert miracles he called upon his divine nature, but when he felt human passions, hunger, thirst, sorrow, etc., he allowed himself to be influenced by his human nature (Concil., v, 1359; Evagrius, ii, I8). The confession of Eutyches, the father of the Monophysites, was "I acknowledge that our Lold originated from I wo natures, but after the union 1 confess only one nature" (ithid, i. 9); cf. Liberatus, Brev., 21. 


\section{Religion in the Sixth Century}

astical foundation, but was sustained merely by the breath of Court favour, as directed by Theodora. At the moment when the prospects of the Monophysites seemed brightest it is probable that disaster from some quarter was imminent and inevitable, but the immediate cause of their ruin was a fortuitous circumstance arising in connection with Justinian's foreign policy. In the beginning of $53^{6}$ l'ope Agapetus arrived at Constantinople, commissioned by Theodahad to effect some favourable accommodation for him with the Emperor. Among the more intimate members of his suite were two deacons of noble family, Vigilius and I'elagius. The Catholic prelates, who were indignant at the elevation of Anthimus, immediately surrounded the Pope and induced him to refuse communion with the new Patriarch unless he should prove his Orthodoxy." Agapetus, therefore, challenged Anthimus to a debate on the articles of the faith in the presence of Justinian, and easily convicted him of flagrant error. Excommunication, notwithstanding the menaces of Theodora, at once followed, and the Emperor could not resist the Pope's demand that he should be expelled from his see. ${ }^{3}$ The Empress at once took him under her personal protection, and gave him private apartments in the Palace." At the same time she began to intrigue for his restoration, and the course of events seemed to shape itself very fortunately in her favour. The Pope died in the spring of the same year before he could set out on his return journey; and concomitantly Belisarius was making brilliant

i Zachariah Myt.; Lib. Pontif., Agapetus, etc.

2 Theophanes, an. 6029.

3 Liberatus, 2 I; Jib. Pontif., loc. cit., J. also threatened at first, whereupon the Pope compared him to Diocletian. Victor Ton. (an. 540) says that Agapetus even excommunicated Theodora.

'John Ephes. Conım., pp. 157, 247. 


\section{Thi Age of Justinian and Thiodora}

progress in his invasion of Italy. Yigilius was a recognized candidate for the see of Rome, and had, in fact, leen irregularly nominated hefore the consecration of .gapetus.' Theodora approached him with hribes and threats; he should be l'ope, and receive also a large pecumiary gramb, if he agreed to alopt the policy she defined for him. Vigilius gave her all the assurances she repuired; he would condemn the Council of ('haleedon and communicate with the three leaders of the Monophysites, Inthimms, severus, and Theo. dosius of Alexandria, the only one who wats in accupation of a see. It her dictation he at once wrote a letter to these prelates, confessing the same faith as themselves; and then he departed for Italy with a mandate for belisarius directing that be should be installed in the lapal seat." He joined the Master of Soldiers at Naples, and, after the capture of that city, accompanied him to kome."

In the meantime, however, lheodahad had filled the vacancy, and caused Silverius to he created lope in due form. When the Byzantine army entered the llestern capital after the flight of the cioths, as already related, Belisarius took up his abode in a palace on the l'incian llill; 5 and, in concert with his wife, who was better versed than himself in such matters, endeavoured to carry out the ecclesiastical policy of the limpress. It lirst, persuasion was tried, in order to induce Silverius to adipt himsclf to altered circum-

1 Lib. Puntif, Buniface 11.

- Vicur Tim. an. 536 ; lilieratus, 22.

"Accordeng to liberatus Antonima forced him bo write llae aforesaid leter from kome: but I cannot help thinking that Theodora exiracled somelding letter foum him than mele professions before she despatched him to the llest with such a powerful imetrument in his hands.

'Virtur Tr,t., an. 536; l.iberalur, 22.

- lib. Pintef, silverius. 


\section{Religion in the Sixth Century}

stances, but he was a strenuous upholder of Orthodoxy and would make no concession. It was decided, therefore, to find a pretext for deposing him, and with that view libels were circulated, insinuating that he was now acting in collusion with the Goths. His residence was in the Lateran palace near the Asinarian gate, and he was accused of plotting to admit the enemy through that portal. He repudiated the charge and removed his habitation to an interior part of the city. ${ }^{1}$ A letter was then forged, in which his treasonable relations with Vitigis were set forth in precise terms; ${ }^{2}$ whereupon he was summoned to the presence of the general on the Pincian. He found Belisarius sitting at the feet of his wife, who was reclining on a couch; and the moment he entered, Antonina addressed him with: "My Lord Pope, what have we done to you and the Romans that you should wish to betray us to the Goths?" She had scarcely finished speaking, when a pair of subservient deacons stripped him of his pallium, and hastily enveloped him in a monkish habit. He was then hurried away to exile, while the information was spread among the populace that the Pope had been made a monk. ${ }^{3}$ After his deposition, Vigilius was consecrated without delay or difficulty, little or nothing being known at Rome of the pledges he had given at the Byzantine Court to apostatize from the Catholic faith. Theodora soon claimed the fulfilment of his promises, but in the West he found himself in an atmosphere where no departure from Orthodoxy would be tolerated, whilst in the East the tide was running so strongly against the Monophysites that no neutral ecclesiastic could be so indiscreet as to espouse their cause. He, therefore, put her off with professions of

1 Liberatus, 22; Lib. Pontif., Silverius.

'Liberatus, 22. 


\section{7t The Age of Justinian and Theodora}

inability and evasive replies, so that the beretics were as far off as cver from being countenanced by the Papal chair.' Vigilius even thought it prudent to purge himself of any suspicion of heresy by writing to Justinian and the Patriarch Menna, who had succeeded Anthimus, in terms which left no doubt of his orthodoxy. ${ }^{2}$ As for Silverius, his first place of exile was Lycia, and from thence reports were sent up to the Court representing that he had been wrongfully accused. Justinian was thus influenced to issue a mandate for him to return to Italy, and clear himself, but, as he drew near to Rome, he was again arrested and deported to the isle of Palmaria, where he died within the year. ${ }^{3}$ It was generally believed that he perished gradually through inanition, the result of his being kept on a very meagre diet by Vigilius; but the definite statement of Procopius that he was made away with by one Eugenius, an assassin suborned by Antonina at the instance of Theodora, has the strongest claims on our credence. ${ }^{5}$

After the death of Silverius, the theological peace of the Vest remained undisturbed for several years; but Justinian and Theodora at New Rome never flagged in their efforts to approach from opposite sides the goal of union between the two great Christian sects. After the deposition of Anthimus, however, the Emperor felt that he had been too yielding to the heretics; and he now allowed the Orthodox bishops of the East to give practical effect to their abhorrence of the Monophysites. It must be admitted, indeed, that the mem-

Lib. Pontif., Vigilius. She wanted him to restore Anthimus, but he sairl he was idiutic when he made such promises, etc. ; cl. lictor Ton., and Liberalus, loc. cit.

${ }^{2}$ Concil., ix, pp. 35, 38 .

Lib. Pontif., Silverjus; Vigilius.

'Liberatus, 22; Lib. I'ontif., Silverius. 
bers of that sect who had flocked to the capital under the impression that the injunction against their teaching had been for ever rescinded, went far beyond the limits of moderation; and entered on a tireless mission which seemed to aim at no less than to proselytize the whole mass of the Constantinopolitans to their creed. ${ }^{1}$ One of the first acts, therefore, of the new Patriarch, Menna, was to convene a Council under the Imperial sanction, at which more than three score bishops and a number of inferior clergy received protests from all parts of the Empire, and pronounced sentence of deprivation against their opponents, wherever they might be found. ${ }^{2}$ A general flight of the sectaries, who had shown themselves to be so irrepressible in the city, ensued; and a repetition of the persecution which marked the accession of Justin was reintegrated throughout the Asiatic provinces. ${ }^{3}$ Nevertheless, the Empress provided secure refuges for numbers of those who were pursued, and even determined by her active interference the tenure of the Patriarchate of Alexandria. That city was the stronghold of the Acephali, and when the episcopal throne became vacant in $53^{6}$, an extremist named Gaianus was immediately elected to fill it by the most powerful local faction." Theodosius,

${ }^{1}$ Concil., viii, 885 . The most determined propagandist was the monk Zooras. His life in John Eph., Com., p. II. "What can I do with a truculent man, who fears no one?" said Justinian, when asked to restrain him.

${ }^{2}$ Concil., viii, 873 et seq.; Nov. xlii.

${ }^{3}$ John Eph., Com., p. 157 et seq. Ephraim, who had been Count of the East, and had been raised to the Patriarchate by a popular vote, was the great persecutor; ibil, pp. 204-207 ; cf. Evagrius, iv. 6 .

${ }^{4}$ When Severus was banished from Antioch and Julian from Halicarnassus, on the accession of Justin, they fled to Alexandria, and there Julian began to inculcate the heresy that the body of Jesus was incorruptible. He was opposed by Severus, and shortly the Alexandrians 


\section{The Ase of Iustinian and Theodora}

who accepted the Henoticon, was the nominee of the local government, as inspired by lheodura, but his confirmation was resisted by violent riots. The limpress at once despatched Narses to establish her candidate hy the aid of the military: and the etmuch had to wage a civil war in the streets of the hostile city, amid showers of missiles launched from windows and from roofs of houses by infuriated women, before he could achieve his object.' Y'et the Orthodox party had become so reinvigorated that the very next year the presence of the Esyptian primate was commanded at the Imperial capital, where he was offered the option of accepting fully the Council of Chalcedon, or of deposition from his see. He chose the latter alternative, and was banished to the Castle of lercos in Thrace, which had been ehosen for the seclusion of Monophysites who were unable, or who had not deigned to escape." Shortly, however, there wats a lull in the storm of Orthodos rancour; and a flourishing brotherhood of Monophysites was permitted to exist at Sycae, where a monastery had been built for them, and liberally endowed by 'Theodora. 'To this establishment Theodosius returned before a twelvemonth, and continued for more than a puar. ter of a century to be the head of it.

Early in the fifth decade of the sinth century the great

were divited into two parties, the Corruptibles and Incorruptibles The latter were in a treat majorily, and wow constituted the Gaianiles. Zachariah Mrt., ix, 9.13: Liberalus, 19, 20.

1 thid. The sullier were beaten, but Narses" won by tire where iron could not," that is, he burnt them out.

- Juhn Eph., Conn., pp. 14, 114 ct sey. : Victor Tom., an. 540, elc.

J John Liph. Cum., pp. 11, 66, 154 elc. Il was opgrsite Blachemae.

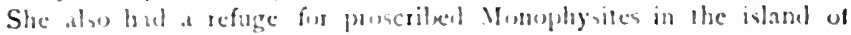
Chins: iht. Zooras wat at firt heat of the monastery at Sycac, but the ended has deys a! bercos. 
theological question which agitated the subsequent years of Justinian's reign, had its origin. Paul, the Alexandrian Patriarch who had replaced Theodosius, became involved shortly after his accession in a scandal connected with the unwarrantable execution of a deacon by Rhodo, the Augustal Praefect. The Emperor and his consort were much affected by this circumstance, and decreed that Paul should be tried for his share in it by an ecclesiastical court. ${ }^{2}$ The Patriarch was convicted, deposed, and one Zoilus appointed in his stead, but these occurrences were merely collateral to the main event. Among the ecclesiastics in favour at the Byzantine Court were Pelagius, the Papal nuncio, and Theodore Ascidas, Bishop of Caesarea in Cappadocia. ${ }^{2}$ Their rivalry for the Imperial patronage was keen, and they were mutually desirous of damaging one another in the es. timation of the sovereign. The court which tried Paul assembled at Gaza (542), and was summoned for the purpose by Pelagius, acting as Imperial Commissioner. Certain monks of Jerusalem availed themselves of his proximity and authority to forward a petition to the Emperor against an antagonistic fraternity who were earnest disseminators of the doctrines of Origen. ${ }^{3}$ The brothers complained of emanated from the New Laura in that region; ${ }^{4}$ and it happened that Theodore Ascidas had formerly been one of their associates. Knowing, therefore, that he would be zealous in the defence of Origen, Pelagius eagerly accepted the advocacy of the complainants as a means of injuring his rival; and on his return to Constantinople at once apprised the Emperor as

1 Liberatus, 23; Procopius, Anec., 27.

2 Liberatus, 23; Evagrius, iv, 38.

${ }^{3}$ Liberatus, 23.

4 The N. L. was founded hy sixty rebels against the rule of Saba; Cyril Scythop, St. Saba, 36. 


\section{7s The Age of Justinian and Theodora}

to the teeming crop of error which threatened to befoul the sources of the faith in Palestine. Justinian listened with avidity, and forthwith began an assiduous study of the works of Origen with a view to the disclosure of noxious passiges. As that father had lived before any definite creed of the Christian faith had been specified, and had been deeply imbued with notions derived from ligyptian and Oriental mythology, Iustinian was shortly successful in unearthing a mass of glaring heresy from his writings. This material was then systematically drafted into canons, which were embodied in a formal recuisition from the Emperor to the Patriarch that Origen should be anathematized in a council of bishops.' In the meantime 'Theodore, anxious to retaliate against l'elagius, and to disturb the convictions of the Orthodox in general, as well as to divert attention from Origen to a greater issue, had devised a skilful attack on the Council of Chalcedon. The action of the Roman legate had created a precedent for reviewing and censuring the opinions of ecelesiastics long since dead; and his adversary perceived that this new method could be applied effectively to damage the authority of the synod in question. Two bishops, who had incurred the charge of Nestorianism, had been expressly approved at Chalcedon; whilst a third, who was infected, bad been passed over without animadiersion."

'Concil, is, 4\$7, 395: Cedienus, i, p. 660 it siy. (c. 544). After this I. wrote a bully pamphlet against Origen (Jn. Wigne, S. G., Ixxxii). Some of the notionn of Origen contemned were, that human souls pre-existed as holy spirits; that at the resurrection human hodies will be glubular; that the sun, moon, and stars, elc., are animated; that Jesus will be crucified again for devils: that punishment in hell will not be eternal, etc. It is scarcely certain that the council was held.

2 Theodore of Mopsuestia, Theodoret, and Ibas. An open lelter of I. spoke of the "blessed Theodore," and said that Cyril, l'atr. of Alex., 


\section{Relugion in the Sixth Century'}

Besides being an Origenist, Theodore was a temperate Monophysite; ${ }^{1}$ and he now persuaded the Emperor that a qualified condemnation of the defunct prelates would purge the Council of every blemish and win for it the acceptance of all of his creed. Justinian again applied himself to his studies, and soon convinced himself that the theologians indicated had been tainted with flagrant impiety; upon which he published an edict wherein their respective errors were reprobated in three sections." In the East but little commotion was occasioned by this document, as the objections were familiar to those accustomed to read the Greek Fathers, but among the Latins the Church was agitated violently because nothing was comprehended ${ }^{3}$ except that the Council of Chalcedon, the decisions of which had been dictated by Pope Leo, was convicted of fallacy. On that side of the Empire, therefore, controversy and stubborn resistance was at once manifested against the Emperor's proscription of the "Three Chapters," the title conveniently bestowed on the matters in dispute."

Justinian, as usual, was determined to carry his point; and he now concluded that the most effective means of attaining his end was to procure a Papal ordinance in confirmation of his own edict. But Vigilius at Rome was beyond the power of persuasion, and might soon not be

arrived first at the Council of Ephesus (431), and "filled their ears with poison and blinded their eyes." Hence Nestorius was condemned without "judgment or question." This document was read and passed at Chalcedon; Concil., vii, 242; xi, 297; cf. Evagrius, ii, I8.

1 Liberatus (24) say's he was an Acephalus, the only authority.

${ }^{2}$ Facundus, Defens., ii, 3; iv, 4.

${ }^{3}$ Pope Vigilius himself confesses that he did not understand Greek; Concil., ix, 98 .

${ }^{4}$ Facundus, Contr. Mociantum; Liberatus, 24, etc. 
amenable even to forec. His presence at Constantinople was, therefore, an urgent necessity; and when the Emperor expressed himself to that effect he was eagerly seconded by Theodora, who was anxious to arraign the Pope for having broken faith with her. With the decision that was habitual to her she resolved that he should be compulsorily deported, and at once despatched an officer with strict injunctions to seize Vigilius wherever be should find him, with the single exception of St. Peter's Cathedral.' 'The Italian capital was not jet beset by the Coths, and the orders of the Empress were executed to the letter (545). In broad day, while: celebrating the holy office in the church of St. Cecilia, the Pope was arrested by a company of guards and hurried through the streets to a ship which lay waiting in the Tiber. A concourse of people thronged after him, and, as soon as they saw him standing without restraint on the deck of the vessel, they clamoured for a benediction. He acceded to their request, and when be had finished, the ship began to put off from the shore. Only then did they realize that he was actually about to leave them, whereupon their demeanour changed suddenly, and they gave a striking proof that they were inspired by two natures. Stones, sticks, and old pots were hurled after the receding pontiff, whilst they yelled abusive epithets at the top of their voices: "Famine and death go with you! You have done badly by the Romans; may you fare ill wherever you go!"2

Vigilius did not now complete the royage to the Imperial city, but, being landed at Syracuse, remained there about a

I.it. Pontif, Vigilius. "If you fail," said she to the officer, "I'll Any sou alive." I have no duuln she held this sort of language wher ervants; but the Lils. Pontif. is a very pour authority.

- lind. 


\section{Religion in the Sixth Century'}

year, ${ }^{1}$ as Justinian was not yet prepared to push the question to a crisis. In 547, however, Emperor and Pope met at Constantinople, and embraced each other with the greatest seeming cordiality. ${ }^{2}$ For some time they worked together in perfect concord, while Justinian entirely won over the head of the Western Church to his views; and in the next year a papal decree was promulgated, under the title of the "Judicatum," in which the Three Chapters were anathematized in the terms dictated by the Imperial theologian. ${ }^{3}$ But this decisive act was the signal for Western indignation to rise to its height; and Vigilius was stricken with awe at finding that he could scarcely count on a single adherent in the Roman half of the Empire. Latin ecclesiastics at once began to compose and circulate elaborate treatises in which they contravened the Imperial and Papal pronouncements and maintained that the proceedings at Chalcedon had been infallible in every detail. ${ }^{5}$ Vigilius, therefore, withdrew his Judicatum without reserve, a measure which caused the tension of opinion between Emperor, Pope, and Patriarch to become acute. The arch-priests excommunicated each other, ${ }^{\circ}$ and Justinian became desperate at finding himself defied at the moment when he believed himself to be in touch with the goal. He issued a new edict (55 I), condemning the Three Chapters, and insisted that the Pope

1 Procopius, De Bel. Goth., iii, 15; Marcel. Com., an. 547; Jn. Malala, p. $48_{3}$. See p. 632.

2 Jn. Malala, p. $4 \delta_{3}$, Theophanes, an. 6039.

3 Facundus, Contr. Moc.; extracts in Concil., ix, ISI.

1 Victor Ton., ann. 549, 550. The African bishops excommunicated the Pope.

${ }^{5}$ Facundus, op. cit. Fulgentius Fer., Epist. 6 (Migne, S. L., Ixrii) etc.

'Jn. Malala, p. 484; Theophanes, an. 6039. 


\section{The Age of Instinian and Theodora}

should sign it.' But Vigilius had now been joined by some Western bishops and clerics, and especially by the resolute Pelagius, who thought the contest demanded his presence in the East. With the support of these coadjutors, Vigilius persisted in his refusal to sign, while the attitude of the Emperor became more and more threatening from day to daty. It length, fearing that personal violence would be resorted to, he fled from his residence in the palace of Placidia to take sanctuary in the adjacent church of st. leter in llormisdas; and here the Pope with some of his supporters sought to save themselves by clinging to the columns of the altar. Is soon as this flight was announced to Justinian, he commanded a praetor with an armed guard to arrest the fugitives in the sanctuary, and drag them to his presence. The military entered the church, followed by a popular concourse, and proceeded to execute their orders. The lesser clerics were soon detached, but Vigilius enubraced the pillars of the altar with all his might. The soldiers laid hold of him, some by the feet, some by the hair and beard, and strove to bear hin off by main force, but the massive structure gave way and would have crushed the pontiff in its fall hat its collapse not been prevented by some of the deacoms standing by:" A groan of horror arose from the crowd of onlookers: the assailants then desisted from the struggle and released their victim. Fearing that he might have gone too far, the practor now called off his men, and retired to inform the Emperor of what had occurred. On hearing his report Justinian decided to proceed no further by compulsion, and sent a deputation to give the l'ope assurances that he might

'Chron. Baschal., an. 552 (also Concil., etc.).

- Vigilius is thoughe wo have leeen a very strong man as he is said to have killed a deacon, who taunted him, with a blow of a brok; Lib. I'ontif. 


\section{Religion in the Sixth Century $68_{3}$}

return to the Placidian palace without fear of being again subjected to physical coercion. ${ }^{1}$ Vigilius acted according to these representations and left the sanctuary; but a few months afterwards his apprehensions were renewed and he again determined to vacate his secular residence. One night, just before Christmas (55I) he crept out at the back of the premises, scaled a half-built wall, and made his way to the water's edge. A boat was in waiting which carried him across to Chalcedon, and there he took refuge in the Church of St. Euphemia. Within the same walls a century previously had been held the famous Council, of which he had involuntarily become the champion. In this retreat a body of delegates, headed by Belisarius, soon arrived, bearing protests from the Emperor as to his pacific intentions, and offering every inducement for the Pope to return to the capital. Vigilius, however, would listen to no entreaties, but drew up a history of his sufferings in the cause of orthodoxy, which he embodied in an Encyclical and published to the whole Christian world. ${ }^{2}$ Justinian now decided that perseverance in violent hostilities would be futile, and that a personal reconciliation with the Pope on any terms would best serve his Church policy. He, therefore, sent Menna and Theodore to offer ample apologies for all that had passed, and to pronise Vigilius that he should in future be free to follow his own course with respect to theological doctrine. The Pope accepted their professions, and, after a mutual withdrawal of anathemas, returned to his quarters in the palace of Placidia. ${ }^{3}$

${ }^{1}$ Epist. Legat. Franc., Concil., ix, I5I (Baronius and Migne, also); Theophanes, an. 6039, etc.

${ }^{2}$ Concil., ix, 50, etc.

${ }^{3}$ Concil., ix, 6i et seq. (also in Col. Avellana). According to Lib. 
Justinian now resolved that his reign should be distinguished by an Ecumenical Council, at which the Catholic faith should be postulated in accordance with his own theological bias. Almost all the Bishops of the East vere willing to confirm his edicts relating to Christian doctrine in a gencral synod: and those who acted in opposition to him did so at the peril of being ejected from their sees. In the spring of 553 , therefore, the assenting prelates poured into Constantinople from diverse regions to the number of one hundred and sixty-five: and the great assembly was held in one of the collateral halls of St. Sophia in the month of May of that year.' 'The clerical concourse were extremely' anxious that Vigilius should take his seat with them at the Council, but he was immutable in his resolution to uphold the Three Chapters. Several deputations waited on him, with whom he held colloquies, but to their invitations he replied invariably that the Oriental bishops were many, whilst in his own following there were but few." In vain they urged that a very small number of Occidental prelates had attended the previous Councils, for he had, in fact, prepared a document, which he denominated his "Constitutum," " to be published before the mecting of the synod, in contraven. tion of its decrees. The Pope had now about him seventeen latin bishops, as well as l'elagius and other clerics, who inspired his determination and appended their signatures to the Constitutum. 'That decretal was a lengthy' composition

I'untif. he was seized in St. Euphemia and dragged round Cl'. till evening, with a rope round his nech, by order of Theodora-fint years after the was slead:

Concil, ix, 157 et seq.; Evagrius, ir, 39.

- Concil., ir, 191 a sey.

llid.. Gr et seg. (anil Col. Arel.). 


\section{Religion in the Sixth Century}

which included the responses of Vigilius to sixty propositions of Theodore Ascidas, but the tenor of it was summed up in a single sentence: "That it was not lawful to subvert anything constituted by the Holy Council of Chalcedon." The Fifth Oecumenical Council, therefore, was held without the presence of the Pope, although he was for the moment resident at its gates; and the discussion of his hostile Constitutum formed an important part of its transactions. The Emperor quoted passages from his Judicatum, ${ }^{2}$ whereby he demonstrated that Vigilius was in contradiction with himself; and ultimately the Council decided that he had associated himself with impiety and voted that his name should be erased from the sacred diptychs. At the same time they asserted that their union with the Apostolical See of Rome remained intact, notwithstanding that they dissociated themselves from the person of the occupying pontiff. ${ }^{3}$ Fourteen canons against the Three Chapters were then proposed and ratified, ${ }^{4}$ and a further rule of credence was thus established for the Christian Church, which Justinian at once proceeded to enforce with all the resources of his sovereignty. A number of recalcitrant ecclesiastics were deprived and banished, or placed in durance, among the latter being Pelagius. ${ }^{5}$ As for Vigilius, since Rome and Italy had now been brought permanently under the dominion of the Emperor by the victories of Narses, he was anxious to return to his see with the Imperial countenance; and within a year after the sitting

'Concil., ix, I03. Seventeen bishops, Pelagins, and two others signed it.

2Ibid., 181. ${ }^{3}$ Ibid., 367.

- Ibid., 376. Origen was practically passed over; can. I6.

5 Victor Ton., an. 553, etc. He was one of them. This chronicler is generally wrong in his dates.

II. 


\section{The Age of Justinian and Theodora}

of the Council he effected a reconciliation with Justinian by the issue of a second Constitutum, by which he retracted the first, and again adrocated the views be had professed in his Iudicatum.' Being thus restored to Court favour he was cotrusted with the Pragmatic Sanction and set out for Rome, as related above; but he was now broken by years, and illness compelled him to interrupt his voyage at Syra. cuse, where be died in the spring of 555." The Emperor now judged sagaciously that the vacant Popedom was an allurement which would dissipate the most assured theological convictions: and he determined to test its potency on the man who above all others was best fitted for the Papal seat. When an intimation was comreyed to the redoubtable champion of Chalcedon, lelagius, that the pontificate was the prize of his recantation, the weapons with which he had so long defended the 'Three Chapters escaped from his nerveless grasp; and, while he accepted the tiara of the llest with one hand, he signed with the other a convention that his faith was assimilated in all respects to that of the princely donor." "The report of his defection preceded him to Komc, and on his arrival there the in. fluence of Narses scarcely availed to incluce three ecclesiastics of sufficient rank to perform the ceremony of his consecration. He had cosenanted with Justinian to enforce the decrees of the lifth General Council in the llest with the authority which attached to the occupant of St. Peter's chair; but the hostility of the I atin bishops was so positive that he was obliged to shelter himself behind ambiguous

1 Concil. ix, 457. He paved the way' by a letien to the new Pati. arch of CI', Rutychius; ibrl., 413 .

- Lib. I'omif.; Marcel. Com., an. 554.

Victor Tom, an. 558; Facunclus, lip. Fid. Cath. 


\section{Religion in the Sixth Century}

utterances and pronouncements as to his unfaltering allegiance to the Council of Chalcedon. He organized a solemn procession to St. Peter's, and, standing before the high altar with the Cross and Gospels held above his head, and the Imperial vicegerent at his side, affirmed his innocence of all the charges which had been made against him. ${ }^{2} \mathrm{He}$ also addressed an Encyclical "To All the People of God," in which he expressed his reverence in detail for everything held sacred in the West, and his especial veneration for the memory of "the Orthodox bishops, Theodoret and Ibas." By these asseverations he won over the Italian people and hierarchs in general to his side, but the sees of Milan and Aquileia for long maintained a schismatic attitude to the pontificate, and the Church of Gaul declined communion with Rome for more than half a century. ${ }^{3}$

The Fifth Oecumenical Council was totally ineffective in procuring a union between the Monophysites and the Catholic world. For more than a decade before that synod the heretics of the One-Nature had been a spreading sect, and they ultimately established themselves as one of the permanent Churches of the East. This result is, perhaps, to be attributed to the steady patronage bestowed on them by Theodora. From the monastery at Sycae, with which she zealously associated herself, emanated several prelates, whose missional activities brought over whole districts and even

1 Lib. Pontif., Pelagius; Marcel. Com., an. 554. There was a popular rumour that he had murdered Vigilius.

2 Epist. 6 (Migne, S. L., lxix, 391).

${ }^{3}$ See his Epistles; Hefele, Hist. Councils, ir, 343, etc., for details of the schism. According to Liberatus (24) Theodore Ascidas gave it as his confidential opinion that he and Pelagius ought to have been burnt alive for the trouble they had brought into the Church over Origen and the Three Chapters. 


\section{The Age of Justinian and Theodora}

mationalities to their creed; and especially that extraordinary man, Jacob Baradacus, in recognition of whose prodigious efforts, sustained for more than thirty years, the title of Monophysites was abrogated in favour of that of Jacobites. After an ascetic seclusion of tifteen years at Constantinople le was (in 5+3) ordained Bishop of Edessa by 'l'heodosius, the exiled Patriarch of Mexandria; and thereafter he pursued his labours untiringly throughout the Asiatic provinces, returning continually from his round to the Imperial or Egyptian capital, where the centres of the sect were maintained. Concealed under a variety of disguises and penetrating the most inaccessible regions, he walked thirty or forty miles daily to win over converts. Inring all this time he eluded the vigilance of those who were eager to capture him, either to obtain the reward offered by the Emperor, or to satiate the rancour of the Orthodox. 'The ordination of two Patriarchs, twenty-seven hishops, and one hundred thousand lesser clergy is recorded as the fruit of his activities.' - Ibout the same time, 'Theodora, in conjunction with 'Theodosius, despatched a missionary to Nubia, who was suecessful in gaining the farour of King silco of that country, and even caused a rival, who was acting in the interests of Justinian, to be dismissed with a rebuff." At the petition of Arethas, prince of the (ihassanides, the Empress also procured the ordination of a bishop for Bostra, a populous town in the north of Arabia." Thus, before her death in 548 ,

' Two lives of him in John Eph., Com., Pp. 160, 206. I moxlem life ly kleyn, leyd., is 82.

$=$ The particulars in John Eph., Ilist. (Smith), p. $250 \mathrm{ct}$ seq.

3 John Eph., Com., 11) 162, 206. In the Semitic, Arethas = Harith. ibn-Gabbala. Duchesne has treated of Christian missions to the south of the Empire at some length; Mis. chret. au sud de l'emp. rom., ising. 


\section{Justinian as a Theologian}

she had the satisfaction of seeing her favourite sect dividing the allegiance of the population with the Catholics throughout Asia and Africa. ${ }^{1}$ Thenceforward, the Orthodox in the East were called Melchites ("Royalists"), in contradistinction to the Jacobites, as representing the Imperial party in religion.

In his relations with religion, Justinian is presented to us in no less than six different aspects. We have seen him as a builder of churches, and as an ecclesiastical statesman; it still remains for us to consider him as a hierarch or clerical legislator, as a persecutor of heretics, as a missionary or converter of the heathen, and as a theologian or Christian metaphysician.

I. In the first department the Emperor enacted Constitutions dealing with clerical life and authority in every relationship, his maxim being that the salvation of the State and the individual depended on the Church being maintained in its integrity. ${ }^{2}$ In the case of a bishopric becoming vacant, three candidates were to be nominated, and the most fit elected by the votes of the ecclesiastics and the principal citizens of the locality; but, if obtained by bribery, the election was annulled. Essential qualifications of a bishop were that he should be above thirty years of age and have no children or grandchildren, whereby his attention might be distracted from his sacred duties. It was necessary also that he should not be addicted to a curia, unless he had gained his freedom from the same, through having spent fifteen years in a monastery. ${ }^{3}$ In the exercise of his office he was

1 She died of cancer of the breast, according to Vict. Ton. (an. 549), who regarded the disease as a penalty of her heretical impiety.

${ }^{2}$ Cod., I, iii, 42 ; Nov. vi, pf., etc.

${ }^{3}$ Cod., I, iii, 42; Nov. vi, I; cxxiii, I; cxxxvii, 2. 


\section{The Age of Justimian and Theodora}

authorized to supervise almost all the activities of civil life. He could demand an account of expenditure from all persons charged with public works, such as baths, roads, bridges, statues, aqueducts, harbours, and fortifications, selecting three experts to assist him with their experience; and he could call on the Rector with his cohort to help him in dealing with recalcitrants.' He was enjoined to prohibit gambling, and to visit the prisons every Sunday in order to inquire into the cases of those under detention. ${ }^{3}$ It was his duty to see that legacies left to the Church or to charities were properly applied by the heirs or trustces: ' and at one time Justinian allowed such bequests to be exacted even after the lapse of a century, but he subsequently reduced the limit to forty years." Litigants could choose him as a judge of first instance, or they could appeal to him from the Rector: but they could also, if dissatisfied with his decision, appeal to the provincial governor." A bishop was immune from charges which were incumbent on ordinary citizens, that is, trusteeships of all kinds. Ite need not accept the post of tutor or curator to young relations, nor the care of those who were demented: " nor could he be compelled to attend in court as a witness." 'The ethics of a bishop's life were scrupulously regulated by law. No woman could be resident in his house, except a wife, a sister, a daughter, or a first cousin. He was not permitted to indulge in any

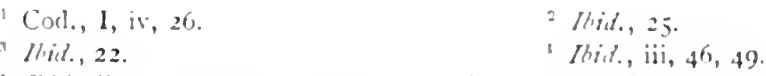

Milil., 22.

2 llitit., 25.

'Thil., iii, 4 h, 49 .

Ilid., ii, 23: Nox. cxxxi, 6: 1, ix: cf. P'rocopius, Anec., 28.

Corl., I, iv, S: Nov, cxxiii, 21.

Cod., I, iii, 52; ir, 27: Nov. cxxiii, 5. He generally supervised their appointment.

- llikl. iii, 7; Nov. cxsiii, 7 .

- Cort., I, iii, 19; Sor. xxii, 42; v, 6. 
gambling game, nor to attend the spectacles of the circus or the theatre. ${ }^{1}$ He also laboured under the disability of being unable to make a will or execute a deed of gift, so that his mind should be wholly free from worldly concern. ${ }^{2}$ The lesser clergy, that is, presbyters, deacons, and sub-deacons, were obliged to live under the same stringent rules as far as applicable to their rank; and only for the lowest grades of the ministry, viz., chanters and readers, was marriage lawful. ${ }^{3}$ But even to them second nuptials were forbidden, under the penalty of forfeiting all claim to promotion in the service of the Church. ${ }^{*}$ The children of illicit marriages contracted by clerics were ignored by the State so far that they were not even entitled to the privileges of bastards. ${ }^{5}$ Nor would the Emperor tolerate idle ecclesiastics, but enacted that all should perform a part methodically in prayers and psalmody for the benefit of the laity. ${ }^{6}$ Women of fifty could be ordained as deaconesses in the Church, but after some time Justinian reduced the age to forty. ${ }^{7}$ The constitution of monasteries was also minutely regulated by legislation. Not the senior, but the most suitable person, was to be elected as abbot or abbess. The segregation of males and females was to be rigidly carried out, and only one old male servitor was to be employed in a nunnery." Husband or wife might elect to lead a religious life without incurring any of the penalties for the neglect of family duties to which an ordinary citizen was exposed. ${ }^{3}$ By entering a monastery the individual divested himself of all his worldly goods in favour of the re-

1 Cod., I, iii, 17; iv, 34; Nor. cxxiii, 10.

2 Cod., I, iii, 42.

${ }^{3}$ Ibid., 45; Nov. xxii, 42, etc.

Nov, xxii, 42.

${ }^{6}$ Ibid., 42.

Cod., I, iii, 45.

; Ibid., 9; Nov. vi, 6; cxxiii, 13.

${ }^{3}$ Cod., I, iii, 44; Nov. v; cxxiii ; cxxxiii.

${ }^{9}$ Cod., I, ii, I 3 ; Nov, v, 5 ; cxxiii, 38 . 


\section{The Age of Justinian and Theodora}

ligious community, but not to the prejudice of wife or children, who were still entitled to their legal share of the estate.' Abduction of a nun, even with her own consent, rendered not only the ravisher liable to capital punishment, but also any persons who harboured or aided him in the crime. Alicnation of Church property, as wetl as of that of monasceries and charitable foundations, was carefully guarded against, and leases were to be granted only to the rich." Ruins, however, and surplus treasure in the form of vessels and restments might be sold to allow of the funds being applied to some more useful purpose.' But an exception was made in the case of money being required for the redemption of captives, "since it was only reasonable to prefer human souls to material valuables." "Some relicf with respect to the incidence of the taxes was also granted to religious bodies in recognition of "the distinction existing between things divine and human." Clerical criminals were punished by expulsion from the cloth and surrendered to be dealt with by the secular arm; in minor cases by relegation to a monastery for three years, there to be subjected to a stringent discipline:

2. The attitude of Justinian towards those of his subjects who did not profess the Orthodox faith was one of the most complete intolerance. A heretic "was scarcely fit to live, and

1 Nur. cxwiii, 38 ; Cod., I, iii, 56.

3hid., 5t: Nor. cxsiii, 43.

${ }^{3}$ Cexl., I, ii, 24; Nor. cxx, 6, 7, elc.

1 Nor. cxx, 1, 10, etc. Corl, , I, ii, 21.

"llid., 22.

"Nov, criii, 20. As Justinian's law's relating to religion are very bulky, I merely give samples bo show their general tendency.

A heretic islefined as anyone not leing an Othodur churchman; Cod., I, v, 12, 1s. 


\section{Justinian as a Theologian}

it was only strict justice for him to be "deprived of all earthly advantages, so that he might languish in misery." " Hence the legal enactments against such religious dissidents subjected them to civil and sometimes to physical death. They were accordingly excluded from all offices of dignity in the State, as well as from holding any magistracy "lest they should be constituted as judges of Christians and bishops." " Similarly, the liberal professions were barred to them, "for fear of their imparting to others their fatal errors." " Wills made by them were not recognized in law unless in favour of Orthodox children or relatives, and, if they had none such, then the Treasury instituted itself as their successor. ${ }^{1}$ The testimony of heretics was not received in court against the Orthodox, ${ }^{5}$ and they were forbidden to hold Christian slaves. ${ }^{6}$ Hence, the slaves of heretics possessed the power of self-emancipation by professing themselves converts to the Orthodox faith. There were, however, degrees in heresy, and the proscriptive laws were not pressed with equal force against all. Manichaeans, Pagans, Montanists and the various sects of Gnostics were the most odious,' whilst Arians, Nestorians, and Monophysites were not pronounced against by name in the first decade of Justinian's reign." The disciples of Mani were frankly condemned to death wherever found, "so that their very name might perish from among the nations." 9 It was a crime to possess their

1 Cod., I, xi, 10.

3 Ibid.

${ }^{5}$ Cod., I, v, 2 I.

'Ibid., v, 11 , 18, 21, etc.

"Nov. cix. By this law heretic wives are deprived of the right to recover their dowry, etc.

${ }^{9}$ Cod., I, v, I2, I6, etc.
2 Ibid., v, I 2.

4 Ilid., 13, IS, I9; Nov. cv, 3.

6 Thid., iii, 56 ; vi, 3 . 
69+ The Age of Iustinian and Theodora

books and not hand them over to a public official in order that they should be burnt.'

Such were the principles which were laid down in the Byzantine state for dealing with heretics, but in practice the penalties were not always strictly enforced, and the law often slumbered unless some special stimulus set it in motion. A couple of years after Iustinian's accession his zeal for Orthodoxy inflamed him with a desire to encompass a general conformity in religion throughout the Empire. He issued a decree, tharefore, that all heretics of the flagrant type would lie under the extreme penalties of the statutes unless they accepted Christianity within three months." As a result, many votaries of polytheism were discovered in the capital, and several high officials were dismissed from their posts. ${ }^{3}$ At the same time, a numerous body of inquisitors pervaded the provinces in order to enforce the edict, whereupon many conformed through fear, whilst others who were fanatically attached to their belief fled to distant regions or even committed suicide.' Among the most insensate devotees of the latter class were the Montanists of Phrygia, who shut themselves up in their churches and then set fire to the buildings, so that all perished together." Prior to this decree Jews and samaritans had enjojed the ordinary protection of the law in their own communities, and only suffered the disabilities of heretics when legally opposed by Catholics; but now the latter sect was included among those upon whom the State religion was to be enforced. In their case the measure was carried out with the greatest harshness, and their synagogues

'Coxl., I, 1, 12, 16, etc.

" Jn. Malala, 1. 449: Theophanes, an. 6022; cf. Cod., I, i, 5.

3 Ibid.

1 Procopius, Anecd., 11.

rbid. 
were closed, emptied of their contents, or altogether ruined.' As the Samaritans were very numerous in Palestine, they soon congregated together, and broke into open revolt. A brigand chief named Julian was chosen as their King, and under his leadership more than twenty thousand of the rebels assembled. Doubtless they were very inefficiently armed and equipped, but they proceeded at once to retaliate on the Christians by pillaging their property, massacring those who came in their way, and setting fire to the churches. Scythopolis and Neapolis were the chief scenes of their depredations. At the first news of the riots the Emperor became very irate and ordered the immediate execution of the local governor, but when subsequent accounts indicated that the movement had attained to the magnitude of a rebellion, he commanded the military Duke of the province to attack Julian with all the forces he could muster. After some preliminary skirmishes a considerable battle was fought, in which the Samaritan King was slain, and his army routed. The head of Julian, encircled with the diadem, was sent as a trophy to Constantinople; and the wretched sectaries were exterminated wherever they could be found among the mountains in which they had taken refuge. Altogether, twenty thousand are said to have perished by the sword; the young of both sexes to an equal number were captured by Arethas, and sold into slavery among the Persians and Indians; but the majority escaped by abandoning their homes and offering themselves as subjects to the Shahinshah. $^{2}$

The devastation and depopulation of Palestine, which resulted from this civil war, had reduced a great part of the

1 Cod., I, v, I7.

2 In. Malala, p. 445 ; Procopius, Anecd., II. 


\section{The Age of Justinian and Theodora}

country to a desert, but, nevertheless, Justinian made no sign that the fiscil precept, for which the province was assessed, would be remitted. Thus the Christians, who had been despoiled by the rebels, were now presented with demand notes for a greatly increased amount.' Extreme destitution was induced, and an appeal to the Emperor became a matter of urgent necessity. The Patriarch of Jerusalem headed the movement, and it was decided that Saba, an anchorite whose reputation for sanctity was greatest in that age, should be the bearer of the petition. He was the founder of the Great Laura in a wilderness near the Jordan, and was now upwards of ninety years of age. He undertook the mission with alacrity and departed for the capital (530), where the rumour of his approach preceded him, and oceasioned a great commotion. A fleet of war-vessels, having the Patriarch Epiphanius and several Illustrious officials on hoard, sailed down the Propontis to meet him: and on his arrival at Court Justinian embraced him with joy and tears. Yet the Emperor was alarmed at the prospect of a reduction of the revenue, and attempted a diversion by offering the saint a large sum for the monasteries in which he was interested. But Saba was immovable and imperturbably pressed his petition for fire concessions, remission of taxes, rebuilding and subsidies for ruined churches, the foundation of a hospital at Jerusalem, the completion of a church to the Virgin in that city, and the erection of a fort in the desert to protect his monasteries from the Saracens. Finally Justinian yielded at every point, and the Holy City was enriched with an infirmary to receive two hundred sick and a magnificent church to the 'Theotokos, which it took twelve years to build, as a part of the tangible outcome of the mission. Jn. Malala, 1. 445; Procopius, Anecd., 11. 


\section{Justinian as a Theologian}

Saba was also brought into the presence of the Empress, who saluted him with the deepest reverence and solicited him to pray for her that she might have a son. But to this request he replied simply, "God save the glory of your Empire," and left her in a very tristful mood. Her depression being noticed, some of the ecclesiastics questioned him, to whom he explained, "Believe me, Fathers, God does not will that there should be any issue of her womb, lest he should vex the Church worse than Anastasius." "

As for the Samaritans, those who survived the blast of persecution, either by pretended conformity or temporary seclusion, formed a considerable multitude. As soon as the penal laws became dormant, they crept out of their hiding places and gradually settled down in their old haunts, so that after the lapse of a decade they again appeared as a conspicuous section of the Palestinian population. In 542 Justinian thought it wise to conciliate them by a formal amnesty, and he published an Act by which they were virtually restored to all their civic privileges. ${ }^{2}$ Yet fourteen years later, they fomented an insurrection at Caesarea in conjunction with some Jews, murdered the Proconsul, and the same scenes of violence against the Christians and their churches were repeated. ${ }^{3}$ A similar wave of oppression, though probably only of local origin, was doubtless the cause of this uprising, but the sedition was soon quelled by a special commissioner, who was sent down from the capital and punished the ringleaders by impalement, decapitation,

${ }^{1}$ Cyril Scythop., St. Saba, 70-72. Saba prophesies that J. will conquer Rome and Africa, which, if the biographer can be relied on, indicates that as early as $53^{\circ}$ the idea of recovering the Western Empire was being mooted.

2 Nov. cxxix. ${ }^{3}$ Jn. Malala, p. 487. 


\section{The Age of Justinian and Theodora}

mutilation, or confiscation of property, according to the degrees of guilt.' Early in the next reign, however, their turbulence appeared to be so incurable as to call for a reenactment of almost all the disabilities under which they lay after Justinian's first decree against them.

It was, of course, a foregone conclusion that in Africa and Italy after the conquest the Irians should be a proscribed sect. No sooner had the Vandal Kingdom passed under the Byzantine rule than the same measure was meted out to the previously dominant religionists, as the African Catholics had generally received at their hands under Genseric and most of his successors. Dispossessed of all their churches and divested of civil rights, they were directed by the Emperor's edict to "consider themselves as humanely" treated in being suffered to live at all." 3 In Italy the revulsion was less decided as, owing to the tolerant policy of Theodoric, the Orthodox Church in that country had not been disturbed. No special legislation, therefore, is extant, and it appears that the Italian Arians were only despoiled on occasion under some specious pretence in order that their riches might go to swell the treasury, as frequently happened in the case of their conquerors of the East.' Although Jews were held in abhorrence by the Emperor and his Catholic subjects, they were allowed to adhere to their traditional faith within certain linits." Thus such a

Jn. Malala, 13. 457 .

2 Nor, cxliv.

Nur, xxsvii; P'rocopius, Anecel., is.

1 Agnellus, Lih. Pontif, Agnellu., 2: l'rocopius, Anecel., 11. . It Kavema all the Guthic churche, with their contents, were handert wer to the Catholics. L'resumably there Were very few Arian cungre. gations left in Italy. The Exocionite Arians at $\mathrm{Cl}^{\prime}$. (Goths) were always respected; Cod., I, v, I2; In. Malala, 1). 428.

Cind., I, ix ; $x$. 
blasphemous departure from the creed of the State as denial of resurrection and judgment, or the creation of angels, was not permitted to them; and they were compelled to use a version of the Old Testament according to the Septuagint in Greek or Latin, and not any Hebrew text of their own. ${ }^{1}$ In one instance, however, a community of Jews at Borium in North Africa were forced to become Christians; and their synagogue, which they declared to have been built by Solomon, was accordingly transformed into a church."

3. Having the power of compulsion in his hands, the efforts of Justinian to convert heathens to Christianity are not easily to be distinguished from persecution. As a rule his chief argument was the sword or the stake, but, as difficulties sometimes stood in the way of applying that mode of persuasion, he was obliged occasionally to have recourse to milder methods. The only notable instance, however, is that in which he appointed John, the Monophysite Bishop of Ephesus, to preach the Gospel in the wilds of Caria, Asia, Phrygia, and Lydia. It seems that in those provinces there were many small communities interspersed among rugged and barely accessible mountain tracts, who were still addicted to some primitive form of idolatry. Some peculiar fitness recommended the heretic prelate to the Emperor for this arduous task; and doubtless it was not intended that the rude proselytes should imbibe any nice theological distinctions. According to the account of the missionary himself his success was very great, and seventy

3 Nov. cxlvi.

2 Procopius, De Aedif., vi, 2. It is only fair to note that Justinian, for the most part, only re-enacted or confirmed laws formulated by his predecessors, beginning with Constantine; but he sometimes enforced them more zealously. 
thousand persons were baptized, for whom a sufficient number of churches and monasteries were built in the sequestered districts which they inhabited. It is probable that this mission conduced to the spread of civilization, and that the regions dealt with were opened by various public works to a freer intercourse with the more advanced dwellers in the plains. Two other examples of Justinian's propagation of the Gospel are rather to be classed as military subjugation and enforeed conversion. On the outskirts of the Empire between Armenia and the Caucasus lived a number of predacious tribes, offshoots of a common stock, called the Tzani. Their homes were situated in mountain fastnesses hemmed in by dense forests, and at an elevation which rendered agriculture impossible. Their sustenance was derived from cattle, and from incursions for the sake of rapine into the surrounding districts. A punitive expedition, bowever, was undertaken by the Byzantine soldiery, who penetrated to their retreats, and reduced them to submission. The permanency of the conquest was then assured by the clearing of avenues for facile access and by the building of forts. Instruction in Christianity naturally followed, and the wild men, who had previously deifed groves and birds, were taught to resort to churches which were erected for their accommodation." Near the eastern extremity of the now Pratecture of Africa a numerous people existed who maintained a magnificent temple served by a throng of hierodules, in which the divinity claimed by Alexander was still adored in conjunction with that of Jupiter Ammon. By a mandate of the Emperor this obsolete religion was abolished, and

1 John Ephes., Hisl. (Smith), pp. 159, 229 at sey.

- Procopius, De Aedif., iii, 6. Sitlas was the general. Cf. Nos. i, pf. 


\section{Justinian as a Theologian}

Christian worship in a church dedicated to the Virgin was substituted for the Pagan rites previously held in honour there. $^{1}$

It is uncertain whether the arrival of barbarian princes at Constantinople, petitioning to be baptized under Imperial patronage, is to be attributed to missionary activity, to the prestige of the Empire, or to accidental persuasion by Christian devotees. ${ }^{2}$ From whatever cause, however, such occurrences were not uncommon, and two further instances may be noticed. ${ }^{3}$ In 527 a king of the Herules presented himself at the Court, with a numerous retinue, and begged to be made a Christian. All were baptized, Justinian himself acting as godfather to the King, whom he dismissed with handsome presents, and an intimation that, for the future, he should rely on him as an ally. ${ }^{\text {}}$ A similar case happened shortly afterwards, which was attended with unfortunate consequences for the royal neophyte, who was a Hunnish chief reigning in the vicinity of Bosporus. On his return, assuming too hastily that all his subjects were ready to follow his example, he seized on the idols of the tribe, which were cast in silver and electron, ${ }^{5}$ and transmuted them into coined money. The native priests, however, were indignant at this act, and, having transferred their allegiance to his brother, quickly procured his assassination. The new ruler then marched against Bosporus, and massacred a small Byzantine force which was habitually stationed there

1 Procopius, De Aedif,, vi, 2.

2 As an illustration of the way in which Christianity was spread unofficially, throush captives carried off by the barbarians, etc., see Zachariah Myt., xii, 7 .

${ }^{3}$ See p. 312.

4 Jn. Malala, p. 427; Theophanes, an. 6020.

5 An alloy of gold and silver; Instit., ii, I.

II.

Z Z 


\section{The Age of Iustimian and Thcodora}

in order to guard the interests of trade with the Huns. This outrage necessitated the despatch of a punitive force across the Euxine, but the barbarians contrived a hasty disappearance without risking a battle, and thereafter the peace of the region remained unmolested.' IIth these cases may be clasted that of the . Mbagi, who dwett heyond Lazica on the north-east of the Euxime. They worshipped roods and groves, but under Justinian received an impulse which caused them to cmbrace Christianity. They were ruled by a dual kingship, the associates in which made a practice of seizing and castrating all handsome boys, whom they sold in great numbers within the Limpire. They lived in elread, however, of the koman power, and hence slew the fathers of such boys, lest they should be moved to appeal to the Emperor against their tyranny: But when a deputation of the Ibasgi appeared at the Byzantine Court to solicit that a bishop should be sent to them, Justinian not only granted their petition, but published and enforced an edict that no more eunuchs should be made in that country. He also built a church to the Virgin among them, so that they should be permanently retained in their attachment to the rites of their new faith.

4. As a doctor of theology Justinian believed himself to be the superior of any of the prelates of the Church who lived in his time. ${ }^{3}$ He pored over the ponderous tomes of the lathers whose subele disquistions on the divine nature

In. Malala, P. 431: Theophane, an. Gozo.

I'rocupius, le licl. (;olh., ir, 3 .

3 Johu Ephes., Hint. (Com.), p. 2.99. In 5.3 he brought a parly of grammariane, whocates, hiphater, and monks from Mevandria, and helat sian es in which the argued w convert them from the Egyptian

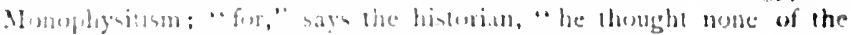
bishop on othe te equal to him in the an of atgument." 
had inspired the decrees of the four great Councils, and assumed the rôle of a priestly expositor of the Catholic faith. As his age advanced, his pious ardour increased, and he pursued his studies far into the night, closeted with venerable ecclesiastics in his library, a circumstance which caused him to incur some contempt among the more active political and military spirits. ${ }^{1}$ Thus, when the plot, in which Artabanes was involved, was organized, the conspirators based their hopes of success chiefly on the facility with which he might be surprised during such nocturnal vigils, bereft of guards, who had been dismissed lest they should disturb his devout researches. ${ }^{2}$ Several of his theological treatises have come down to us, which, though not voluminous, might have sufficed to give hinı a respectable rank among ecclesiastical authors, had not his royal position rendered him independent of such distinction. As a specimen of the intellectual activities of an age, in which philosophy and science had been abandoned as worthless pursuits, it may be interesting to quote two passages from Justinian's writings, wherein damnable heresy may be seen opposed to the inestimable conceptions of orthodoxy. In the first he exposes the pernicious errors of Origen, in order that they may be anathematized by an episcopal council; and in the second he defines the true views which must be held as to the ineffable conjunction of the two natures in the Saviour. The Palestinian monks, who cherished the Alexandrian Father, he urges, were engaged in ruining souls by infusing into them ideas assimilated to those of Pythagoras, Plato, and Plotinus, thus perverting them towards the tenets of Paganism and Manichaeanism. ${ }^{3}$

1 Procopius, De Bel. Goth., iii, 32.

${ }^{3}$ Cedrenus, i, p. 660 et seg.

2 See p. 622. 


\section{The Age of Justinian and Thoodorat}

". . . They say," expounds Justinian, "that there were origin. ally an innumerable host of minds united in contemplation and love of God. But, being subdued by satiety, their devotion cooled, and hence they became associated with boclies and names of a bigher or lower nature in proportion to the degree of their falling off. Those who were least deteriorated passed into the sun, moon, and stars: a lower class into gross bodies like our own; whilst those affected with the greatest perversity coalesced with the frigid and fuliginous matter of which demons are constituted. One only remained unchanged in lore and contemplation of the Deity, and that one was Christ. Iitt all bodies are liable to perish utterly; and he, becoming at once God and man, first threw ofi his body; and all bodies will ultimately do likewise, returning into unity and again becoming minds. Hence impious men and demons will at last attain to the same celestial state as the divine and saintly. Thus Christ differs in no manner from other lising beings. but Pythagroras said that unity was the beginning of all things; and Plato taught similarly, and asserted that souls were sent into bodies as a punishment. Wherefore he called the body a sepulchte and a chain, as being that wherein the soul was buried and bound. And the soul of a philosopher which pollutes itself with paederasty and iniquity performs a triple circuit of chastisement in a millennium, and in the thousandth year becomes winged and takes its flight.... Therefore I exhort you, holy fathers, to examine and condemn in general synod all "ho think like Origen."

The next extract I draw from his lengthy exposition of the principles of Catholicism with a view to the condemnation of the Three Chapters. In this document he relies mainly on the interpretation of Scripture by Athanasius, Cyril of Alexandria, Basil the Great, Gregory Nazianzen, and Gregory of N'ssa ':

". . And when we say that Christ is God, we do not deny" him to be man; and when we say that he is man we do not deny"

'Chron. Paschal., an. 552. 
him to be God. For should he be only God, how should he suffer, be crucified, and die? For such is alien to God. Wherefore when we say that Christ is composed of both natures, divine and human, we introduce no confusion in the union, but in the two natures we confess Jesus Christ, the Incarnate Word. When we say that there is a composition, we must allow there to be parts in the whole, and the whole to consist in its parts. The divine nature is not transmuted into the human, nor the human into the divine. Rather is it to be understood that, each nature abiding within its own limits and faculties, a union has been made according to the substance. The union according to the substance signifies that God the Word, that is, one substance of the three substances of the Deity, was not united to a previously formed human body, but created for Himself in the womb of the Holy Virgin from her substance the living fesh, which is human nature."

He then drew up a number of canons against the Three Chapters and heretics generally, to which he appended a diffuse argument to prove the necessity for their being anathematized. These canons are virtually the same as the fourteen adopted by the Fifth Oecumenical Council. ${ }^{1}$

1 Three considerable monographs treat of religion in the sixth century: Duchesne, Vigile et Pelage (Rev. d. quest. hist., 1884); Linecht, Die Relig. Polit. Kais. Justin., Wiirz., I896; and Hutton, The Church in the Sixth Cent., Lond., 1897 . Gasquet's De l'autor. impér. en mat. relig. à Byzancc, Paris, 1879 , also contains matter germane to the subject. 


\section{CHAP'ER XY}

\section{PECL'LIARIIES OF ROMAN I.AW: THE I.LGISLATION OF IUSTINI.1.}

THE mutual relations of the members of a community 1 naturally fa!l into two divisions, that is, public and private.' In the first we have to consider the activities of the citizens politically, or with reference to the work of the government or administration, which enacts, or sanctions and enforces, the laws under which they live. In this sphere of sociology the connection of the individuals with each other arises only through their dwelling in contiguity within some circumscribed area, and thus, white being obliged to exist under the same human infuences, they may for the most part be personally strangers to each other. In this department, then, the tie of natural affection, which originate: in blood or sexual relationship, or, perhaps, from friendly association, is in gencral wanting. In the second category the community must be regarded as consisting of an aggregate of natural groups, that is, families, the members of which are so intimately comected as to be affected at every moment by each other's acts. Such groups in their mutual relations are necessarily subjert to the laws of the state: but in the privary of the family circle it is also essential that the in.

$$
\text { Pand., 1, i, 1: Imatil., i, I. }
$$


dividuals should conform to a minor system of law, which may vary in every household according to the expediency of its particular circumstances. Of the latter code of conduct it will be unnecessary to speak further; it might be identical in part or wholly, in ancient and modern times, and among different nations, or differ considerably in families living in the same age and adjacent to one another. But statute law affects similarly all persons subject to its jurisdiction, and it is of this only we have to treat.

The origin of, and necessity for, law, humanly enacted, arises from the gregarious tendency of mankind, through which the desires and acts of the individual become circumscribed with reference to those of his neighbours. At a very early stage in civilization the conception of individual rights is awakened by each person becoming keenly perceptive of self-interest; and hence those in a neutral position feel inclined to resent that another should suffer a wrong to which they themselves would be unwilling to submit. Thus the germs of altruism are sown in a community, and the general utility of some rule of justice being enforced soon becomes apparent to all. Yet each one is loth to abandon advantages which he finds to be within his grasp; and the abuse of power leads to oppression, injustice, and crime. Power is of various kinds, and consists in the ability to take from another some valued thing by open force, by strict legality, or by stealth. The last-named is theft, and, in its various aspects, creates the necessity for almost all criminal law; but the former are with difficulty dealt with by, and sometimes form the paradox of legislation. Thus, by a general convention the greatest injustice may be enforced within a state, and that in two relationships, viz., as regards the members of other states, and with respect to its own citizens. In the 


\section{joS The Age of Justinian and Theodora}

category thus indicated I propose to advert only to two phenomena in Roman sociology, namely, slavery and debt.

I. In modern times the only slavery recognized in Western civilization has been that of some degraded race, whom nature seems to have created as almost akin to the lower animals. Hence it was considered to be no injustice to subjugate or domesticate them as such, and to pass them from owner to owner at a price. But the Roman slave, as a rule, was not racially distinguishable from his master; and might even be his superior in natural endowments and education. For the latter advantage, however, he would almost invariably be indebted to his owner. He was generally a member of a foreign state, most probably a captive taken in war, or the descendant of one; but sale by parents within the Roman dominions and kidnapping were not uncommon. In the early ages of the Republic the master had as much power over his slave as over his ox or his ass, and lay under no penalty if he should choose to kill him; but the position of the human commodity was gradually ameliorated. The advance of humane conceptions, which attained their most emphatic expression in the Stoic philosophy, ${ }^{1}$ soon exerted its influence on the servile condition; and even under Augustus a master could not imperil the life of his slave without first obtaining magisterial sanction.' Half a century later it was enacted by Claudius that a man who wantonly killed his slave should be guilty of murder." Hadrian 'and the Antonines ${ }^{3}$ legislated in the same spirit

Lee p. 241 .

2 Pand. XLVIII, viii, I I, etc. Illustrated by the story of Androcles and the lion; Aulus Gel., $v$ I4.

Suelonius, Claudius, 25.

- IIist. Aug., IIadrian, 18.

5 (iaius, i, 52, elc.; Seneca, l)e lenef., iii, 22 ; see P. 43. 
to protect them from cruelty, and gave them the right of being compulsorily sold when they had just cause of complaint against their actual owner.' It has already been mentioned that Constantine, ${ }^{2}$ although a slave could have no legal relatives, forbade that servile families should be separated by sale to different persons; but, nevertheless, in the sixth century the abolition of slavery was never contemplated as a social possibility. A Roman slave wore no badge of servitude, and when on one occasion it was proposed that they should do so, the proposition was negatived on the grounds that it would be hazardous to provide them with a means of recognizing how very numerous they were. ${ }^{3}$

Such, in general, was the position of slaves within the Empire when Justinian cane to the throne; and in many important details they were indebted to him for an increase of their privileges. That emperor was a busy law-giver in every department of the state; and, when not blinded by fanaticism or financial greed, his measures tended to the extension of liberty and the removal of technical restrictions. Obstacles were placed in the way of the manumission of slaves, and in many the freedom bestowed was only partial. Justinian abolished such irksome distinctions, and decreed that all freedmen should enjoy the full rank of Roman citizenship irrespective of their previous status or formalities in the mode of manumission." By a law passed in the time of Augustus a man could not by will confer liberty on all his slaves, but only on a proportion of them $;^{5}$ and a youth who was considered to have attained to manhood, that is, to

\footnotetext{
1 Cf. Cod., I, xxv.

${ }^{3}$ Seneca, De Clement., i, 24.

${ }^{4}$ Cod. VII, vi ; vii ; Instit., i, 5 .

${ }^{5}$ Suetonius, Octarius Aug., 40; Gaius, i, 42 et seq.

2 See p. I1 4 .
} 


\section{The Age of Justimian and Theodora}

fourteen years of age, so that he could legally make a will, yet was denied the power of manumitting a slave. The first of these enactments was abrogated,' the second modified by Justinian." In the case of a slave being in the joint possession of two or more persons, and one of the owners desiring to manumit, he made it compulsory that the others should sell their share to that one; ${ }^{*}$ and if a free woman married a slave he enacted that she should retain her liberty, contrary to previous law on the subject.' He also forbade the prostitution of female slares, to whom in such case he ordained that freedom should at once accrue as a consequence of the offence. ${ }^{5}$ In general he declared himself to be the friend of liberty," and endeavoured to expedite the solution of all legal difficulties in wills, and the wishes of testators in farour of the slave being speedily emancipated.' Finally he deprived the slave of the option of remaining in servitude, stating that no one had the right to reject the gift of Roman citizenship." He asserted, however, very strictly that a freedman should fulfil his duties towards his patron, that is, his former master, to whose generosity he owed his liberty, and threatened him with relapse into servitude should he prove himself to be an ingrate. ${ }^{9}$ But he relaxed the rule which compelled a freedman to leave half his property to his patron; and in ordinary

' Cod., VII, iii; Instit., i, 7 .

: Instit., $\mathbf{i}, 6$. Ile allowed him 10 manmmil at 17 instcad of 20 as previously.

Cod., VII, vii, I.

"llid, , vi.

' lliti., xxir; Instit., iii, 13.

"livid., vii, 2 .

"Cod., VI, xxxv, ii; VII, ii, 15. He quotes a sentiment of Lucan, "To think nothing accomplished while anything remained to be done," ifropos of some legislation of Marcus Aurelius, which he essays to complete.

"Mir.

Nos: laxviii. 


\section{Pcouliaritics of Roman Law}

cases relieved him altogether of the obligation, ${ }^{1}$ whilst he also attempted to institute some legal relationship among the emancipated by tracing the connections of a family through those still retained in slavery. ${ }^{2}$ Another liberal provision of this Emperor was that if an unmarried man kept one of his slaves as a concubine and died intestate, she and her children forthwith became free instead of passing into the hands of the heirs as part of the inheritance. ${ }^{3} \mathrm{He}$ also pronounced against foundlings being reduced into servitude, either as slaves or serfs, ${ }^{4}$ on the assumption that they were not free born. By the same rule a slave cast out or abandoned, the fate sometimes of those who had become useless through illness or decrepitude, became free. ${ }^{3}$ Yet the colons or serfs of an estate gained no step towards freedom in this reign; on the contrary Justinian confirmed the laws which bound them to the soil and interdicted them from migrating to another locality under pain of forfeiting their chance of being emancipated. ${ }^{6}$ In this connection he feared, doubtless, lest anything which might hamper the profitable cultivation of estates would lessen the returns to the fisc.

2. The very harsh laws of debt, which prevailed among the primitive Romans, were one of the chief sources of civil commotion in the first centuries of the Republic. The defaulting debtor might be seized by his creditor, imprisoned, and sold as a slave; and the terms of one law of the Twelve Tables have been held by many jurists to indicate that joint creditors were legally empowered to hew the body of their

\footnotetext{
${ }^{1}$ Instit., iii, 8. $\because$ Cod., VI, iv, 4; Instit., iii, 7.

${ }^{3}$ Cod., VII, $x v, 3$.

4 Cod., I, iv, 24; VIII, lii, 3 ; Nov. cliii.

s Cod., VIII, lii, 4; Nov. cliii, 1.

${ }^{6}$ Cod., XI, xlvii, 23, etc.
} 


\section{The Age of Justimian and Theodora}

lebtor in pieces in order that each of them might take possession of a section.' 'The various popular measures which were passed from time to time with the view of relieving the citizens of debt and restraining the oppressive creditor are treated of at length by the Latin historians. Such enactments compelled a spirit of moderation among those who practised usury, and many debtors were assisted by arangements comparable to modern bankruptcy. Ultimately the increase of power and wealth in the Republic, and the concessions granted to the overflowing population by aspirants to personal dominion effaced most of the hardships which were so galling in the primitive community; but no permanent legislation was ever devised which effectually curbed a creditor prone to drastic exaction of money due. Thus in the eleventh year of this reign we find Justinian forbidding that the corpse of a debtor should be impounded with the object of forcing immediate payment of a debt from his heirs, the attached penalty being confiscation of the sum owing, together with a third of the fortune of the offending person. ${ }^{3}$ And nearly twenty years later he was obliged to enact that creditors should not seize the sons of debtors and retain them in slavery as a gage of the amount owing being paid." In this case the delinquents were to forfeit the debt and also an equal sum to the youth kept in bondage, and in addition were to be sentenced to a flogging by the local Rector. It the same time the Emperor decreed that securities giren by women in respect of their husband's debts were to be roid of effect; whilst under no circumstances were females, even when liable to the fisc, to be sent to a

\footnotetext{
XIl Tab., iii, 5 (Aul. Gel., xx, 1).

- I.ivg, vi, 34; vii, 42, etc.

3 Nov. Ix.
}

- Nov. cxxsiv, 7. 


\section{Peculiaritics of Roman Law $\quad 713$}

common prison for debt. 'They were only to be immured in monasterics or ascetic establishments, where they would be in charge of custodians of their own sex.' Justinian also legislated in restriction of interest on money lent, which in this age seems generally to have been calculated at twelve per cent. per annum. He now fixed the precise amount which he considered it fair for lenders to receive in proportion to the risk they ran and the importance to them of the transaction. Thus nobles of Illustrious rank were allowed to take only four per cent.; but ordinary citizens were to be entitled to six. Merchants in legitimate trade, if they lent money, might demand eight per cent.; but the investor in any risky venture, such as nautical enterprises, was permittted to stipulate for twelve per cent."

The despotic power exercised by a Roman father over his family, expressed by patria potestas, was almost peculiar to that nation, but in practice it seems to have been very rarely abused. By this convention wife and children were subjected to the male parent almost as completely as if they had been his slaves; but at the same time sons of mature age had all the rights of citizens with respect to voting at elections, holding magistracies, and commanding armies. By tacit consent, however, this exaggerated jurisdiction was gradually abandoned, and in the time of Justinian had become more nominal than real. ${ }^{3}$ Thus already, during the reign of Augustus, it was agreed that a father could not inflict more than ordinary chastisement on a son without obtaining magisterial sanction;" whilst Constantine publicly decreed

1 Nov. cxxxiv, 8, 9.

2 Cod., IV, xxxii, 26; Nov, cri; cxxxriii, etc.

${ }^{3}$ Instit., i, 9; Cod., VIII, xIvii.

4 Seneca, De Clement., i, I4, I5. 
that a parent who killed his child should suffer death by the paradoxical method invented to emphasize the unspeakable atrocity of the crime of parricide.' But two centuries preriously Hadrian had pronounced it to be "illicit and disgraceful "for a father even to sell his children." Justinian began early to limit by definite legislation the extent of paternal absolutism, and in 533 decreed that patricians should be released from it, on the grounds that it was "intolerable for one whom the Emperor had chosen to be his father" to lie under such a disability: ${ }^{3}$ At the same time he forbade parents to oppose by any overt act the resolution of any of their offspring who should elect to lead a religious life; providing, however, that if the latter should tire of asceticism and return to the world, the special favours shown to them should be withdrawn.' Six years later he followed up the principle by declaring the exemption of practically all high officials, viz., consuls, ordinary or honorary, praetorian prefects, and those of the two Romes, masters of soldiers, and, of course, bishops." Justinian also abolished the power of the father to surrender his children to those upon whom they had inflicted an injury in lieu of compensation. ${ }^{6}$ Further, he issued Constitutions in which he reiterated more emphatically the prohibition against the exposure of infants. ${ }^{7}$

Originally a son could have nothing of his own during the lifetime of his father, but in the reign of Augustus an exception was made in favour of whatever he might gain in

'Cod., IX, xvii. IIe was to be thrown into the sea sewn up in a sack with a dog, a cock, a viper, and an ape; cf. Instil., iv, 18.

$\triangle$ Cod., VII, xvi, I ; cf. I'and., XLIIII, ix, 5.

3 See p. 90. $\quad$ Corl, I, iii, 55; Nov, cxxiii, 41, elc.

3 Non. Ixxxi.

"Instil., iv, 8 .

Cuct, VIII, lii, 3; Nor cliii. 
military service. ${ }^{1}$ In the first half of the fourth century the right was extended, and the privilege of retaining anything received as pay from the government was bestowed on officials of the civil service. ${ }^{2}$ Justinian went a step further and enacted that a son's independent or extraneous earnings should be his own, but yet he permitted the father to have the usufruct of any capital thus acquired. ${ }^{3}$ Later (54I), he made another concession that a son might inherit anything from a relative, as part of his separate estate, if left to him with a proviso that it should not come under his father's control. ${ }^{4}$

The artificial conception of blood-relationship which prevailed among the Romans, whereby those connected through females were excluded from all legal rights in a family, had been modified in some of its most inequitable features before the sixth century. In the earliest times if a citizen died intestate having no agnates to inherit, that is, persons related to him through males, the property was divided among his gens. The latter consisted of all those of the same stock or name as himself, being the reputed descendants in the male line of some common ancestor. Possibly, however, by this dispensation some of his heirs might not even be of the same blood, owing to adoptive children having conferred upon them all the legal rights of those naturally born to the father by whom they had been assumed. Thus it happened that the children of a married daughter could claim nothing of their maternal grandfather's estate; and, as a rule, their mother would be in the same position. A mother could not inherit from her sons and daughters; whilst emancipated

1 Gaius, ii, 106; Juvenal, Sat. xvi, 51.

= Cod., XII, xxxvii.

+ Nov. cxvii, I; cf. cxxxir, II.

${ }^{3}$ Cod, , VI, Ixi, 6 


\section{The Age of Justinian and Theodora}

children, that is, those who had been relieved by their father from the semi-servile condition in which they stood towards him, thereafter became as strangers to their own family in the eye of the law. The narrow conceptions of the primitive laws as defined in the Twelve Tables $(+62$ 1.c.) were productive of much flagrant injustice of this lind, as it appeared to the Komans themselves as time wore on. ${ }^{1}$ After the lapse of about a century, a new magistrate, second in authority only to the Consuls, was created under the title of Practor, and his functions gradually evolved themselves into those of the chief justice of the Republic." Nithough legislative powers were not bestowed on him, he became virtually a legislator, and in his court equity was administered in accordance with the current development of public opinion. Thus he became a special providence for all those who found themselves hard pressed by the cramped enactments of the old laws, which were sometimes supplemented, sometimes evaded by a legal fiction or subterfuge in the Praetor's Court. ${ }^{3}$ On taking office, each Praetor published an edict in which he stated the views he took of debatable questions in law; and his rules and decisions, though caduciary, were often confirmed and fixed by Imperial legislation." By the reign of Hadrian a considerable body of law had been thus concreted, which that emperor ordered to be codified by Salvius Julianus, and thus a collection of statutes, called the Per-

1 Generally see . Wuirhead's Private Law of Rome (by Guuld), Edin., $1899, \mathrm{pp} .163,270 \mathrm{ds} y$, and the reconstruction of the Xil Tals. thereto appended; also Gaius, iii, is, etc.

2 Livy, vi, 42 ; vii, 1, etc.

${ }^{3}$ Pand., I, i, 7.

4 The way in which the Pretor gave relief to those hard pressed by the letter of the law, is expressed very clearly throughout the Institutes, especially in iii, 1, 2, 9, elc. 
petual Edict, was permanently approved and took the place of the variable practice of successive Praetors. ${ }^{1}$

While in Republican times the rights of succession to an intestacy had been constrained within narrow limits of agnation and male precedence, ${ }^{2}$ the laws of inheritance as ultimately settled by Justinian became the most liberal that the world has seen. Priority of birth had never been recognized as constituting a title to preference in Roman law; and now every notion of any prescriptive claim being inherent in sex was abolished. The state of the deceased was divided equally between male and female children, grandchildren, of course, subdividing a predeceased parent's share. By this disposition a wife took her marriage settlement, but if there were none such she ranked as one of the children, as did also a husband. If the intestate left no issue, but several brothers and sisters, the property devolved on them according to the same principle, but to them the parents of the deceased, if living, were preferred. Thus the degree of affinity by blood was alone considered in regulating heirship. Under this system adopted children inherited from their natural parents as if no such formality had taken place, but they also had a claim, in the absence of near kindred, to succeed to those who had adopted them. ${ }^{3}$

In the earliest times a Roman could bequeath his property to any member of the community he pleased, but not to a foreigner. In the time of Augustus, however, a law was passed, in completion of previous tentative efforts, which made it compulsory for him to leave a fourth part of his

'Eutropius, viii, 9; Cod. I, xvii, Tanta ( $\left.\dot{t}^{\prime} \delta \omega \kappa \varepsilon \nu\right)$, etc.

¿ By the XII Tab., as J. points out, males and females, apart from agnation, had equal rights in successions; Cod., VI, Iviii, I4.

${ }^{3}$ Nov. cxviii; cxxvii ; cf. Instit., i, II; iii, I.

II. 


\section{is The Age of Justinian and Theodora}

estate to his children, otherwise he had to state expressly' why he disinherited them.' Justinian confirmed and reduced legislation of this class to a compact form, defining the relations of parents and children to each other as regards the disposition of their possessions in precise terms. Fourteen causes were enumerated, which the law would recognize as just grounds for a parent to disinherit a child, and eight which would confer the same right on the latter. Among these, lapse into heresy holds the most prominent place, and also neglect to ransom if the parent or child should be taken captive by an enemy."

'The dissolute tendencies of socicty under the early Empire induced the promulgation of laws which imposed a penalty on celibacy, and granted privileges to those citizens who were fertile in offspring. Legal incapacity to inherit was inflicted on a bachelor, whilst in the division of an estate larger amounts were assigned to the heirs in proportion to the number of their children. ${ }^{3}$ With the introduction of Christianity and asceticism, qualities of this kind began to occupy reversed positions; and, if marriage did not fall altogether into disrepute, second nuptials, at least, were ranked almost as a crime deserving to be visited with penalties comparable to those decreed against heretics.' Justinian modified this stringency, remarking that natural passion might fairly lead persons of both sexes to re-marry, and that free procreation

i The Lex Falcidia, concerning which there is much matter in Code, Pand., and Nor., etc. ; cf. Gaius, ii, 226.

"Nov. cww. Olher causes for disinheriting were a son going on the sage, or a daughter under twenty-five refusing to marry a certain person, eic.

${ }^{3}$ Lex Papia-Poppaen, Pand., XXXVIII, xi; XXIII, i, and commenators; Gaius, i, 178, etc.

- Cod., $\mathrm{r}$, ix. 


\section{Peculiarities of Roman Law}

of children was ultimately for the benefit of the state. Legitimation of children by subsequent marriage had long been recognized, and Justinian extended the principle by a decree that a woman seduced under promise of marriage could compel her lover to complete the contract, or, in default, to endow her with a quarter of his property. ${ }^{2}$ By a law of Anastasius, illegitimate children were called on to inherit the estate in the case of an intestacy without legal offspring, but in the second year of Justin this rule was abrogated. At the beginning of his reign, however, Justinian restored the former claim to the extent of one half, and later he supplemented it by enacting that a father could leave all his possessions to his natural children if he had none who were legitimate. ${ }^{3}$

From the first ages of the Republic liberty to divorce his wife was considered to be the inalienable right of every Roman, but the privilege was rarely, if ever, taken advantage of in the primitive community. This strict attachment, however, to the conjugal contract gradually disappeared, and in Imperial times the marriage bond was tied and loosed on many occasions in their lives by persons of unstable character. Not until the fifth century did the Christian emperors attempt to impose any stringency on the freedom of divorce, when the younger Theodosius published a list of offences, in the

1 Cod., VI, xl; Nov. xxii, 43. He speaks of a law said to have been passed by one Julius Miscellus, but there was no such person. For a clue to the muddle, see Daremberg and S. Dict. Antiq. $s b$. Lex, where the best list of these old laws will be found.

2 Nov. lxxiv, 4, etc. He excuses these lapses by "nothing is stronger than the fury of love, and how can those so affected resist the blandish. ments of those they love?"

${ }^{3}$ Cod. V, xxvii, 6, 7, 8; Nov. 1xxxix, 12, 15, etc. Incestuous children are, however, barred from all such privileges. 


\section{The Age of Justinian and Theodora}

absence of one or more of which repudiation of the nuptial tie by either husband or wife would be legally insufficient.' From the moment of his accession Justinian began to elaborate legislation of this kind, ${ }^{2}$ and in 541 went so far as to forbid the dissolution of marriage by mutual consent, ${ }^{3}$ a right with which no previous emperor had ventured to interfere. The restriction, however, was probably inoperative and highly unpopular, and one of the first acts of his successor was the repeal of the obnoxious measure.'

The difficulties which in this age beset the practice of the law courts, owing to the confused condition of legal literature and the consequent absence of attainable information on forensic questions, has already been adverted to. 'The pressing need of rescuing the elements of jurisprudence from the two thousand volumes in which they were entombed had been felt by previous emperors, but, if they apprehended the possibility of executing it, they shrunk from the magnitude of the task. No sooner, however, was Justinian seated on the throne than he engaged in this enterprise and nominated a commission of ten jurists to prepare a code in which all extant and effective Acts of various emperors should be repeated and arranged in lucid order. Tribonian was included among these commissioners, as an adjurant rather than as a principal, but during the execution of the work it is certain that he proved himself to be the master spirit of the undertaking. The materials which had to be manipulated consisted of the Theodosian Code, in sixteen books, com-

1 Cod., r, xvii, S.

2 Slit., 11; Nov. xxii. Some of Justinian's just causes of divorce are procuring alontion and bathing in the public laths with men. Wife. beaters are not divorceable, but nust make large pecuniary compensa. tion; Nove cavii, 1.4 .

${ }^{3}$ Nor. cxrii, 10; cxxaiv, 11.

- Nor. al. 


\section{The Legislation of Justinian}

posed under the auspices of that feeble-minded prince, whose simple piety assumed that all but the laws of Christian emperors should be expunged from the statute book. This ineffective performance, therefore, left unnoticed all legislation previous to Constantine, but there were two other extensive compilations, the Gregorian and Hermogenian Codes, of private origin, in which had been amassed a multitude of Imperial constitutions, beginning with those of Hadrian. The work was begun in February, 528, and finished by April of the following year. It was then announced to the Praefect of the East as the "Justinian Code," to which alone for the future reference was to be made in order to ascertain the law of the Empire; and he was directed to give it effect from the next month. If, the Emperor added, certain enactments were found to have been altered in tenor by additions, detractions, or verbal changes, such modifications had been necessitated by the exigences of the age; and it was forbidden that anyone should thereafter cite such passages as they appeared in previous books, with the view of inducing decisions not in conformity with the new Code. ${ }^{1}$

The capacity and erudition of Tribonian, which had been revealed during the preparation of the Code, inspired Justinian to undertake in the next year a work of much greater magnitude, which it was anticipated would demand fully ten years for its achievement. It was proposed to extract all the essential pronouncements of jurisprudential law to be found in the two thousand volumes, which emanated from the recognized legal luminaries of the previous fourteen centuries, and dispose them categorically in fifty books, so that they should be readily available for forensic consultation. The

1 See the two prefaces to the Code. 


\section{The Age of Justinian and Theodora}

Constitution which enjoined the preparation of this comprehensive work, to be called the "Digest," or "Pandects," was addressed to Tribonian alone, and he was left untrammelled in the choice of coadjutors in the stupendous task.' Nowhere throughout the Empire, indeed, was there known to be a legal library which contained all the books necessary for the compilation of the Pandects, except in the collection which had been formed with vast pains and accurate judgment by Tribonian. ${ }^{2}$ He now made choice of sixteen associates, and all engaged assiduously on the materials at their disposal. 'To their surprise, they found that the work advanced much more rapidly than had been expected, and at the end of three years they were able to announce that the Digest had assumed a practical shape. The three million sentences had been reduced to one hundred and fifty thousand, which were distributed in an orderly manner throughout the fifty books in seven categories. Among these were to be found all the matter required to enlighten the hesitating lawyer as to official duties, judicial functions, pledges, contracts, usury, nuptials, wills and codicils, legacies and trusts, relations of slaves and freemen, heirship, intestacy, liabilities of those occupying land and dwellings, crimes and punishments in "two terrible books," public works, and miscellaneous definitions. " Having achieved this great work Justinian became apprehensive that it would be corrupted by copyists, wherefore he ordained that no abbreviations

'Cnd., I, xvii, 1.

- As mentioned in Cirl., I, xvii, 2, 3 (Tamta and Jidunen).

${ }^{3}$ Thirly-nine legal writers were excepped, hut many uhers are referred to incidentally. A sketeh of the origin and derelopment of lioman law, as well as the names and connection of the chicf practition. irs, from l'onponius, is includel; P'and., I, ii, 2. 


\section{The Legislation of Justinian}

should be used in writing out the original or reproductions. But he was still more alarmed lest his concentrated text should be overwhelmed by commentators, so that after the lapse of a certain period there might be a return to the former state of things, when administrators of the law should again suffer bewilderment amid the overplus of legal literature. Commentaries, therefore, were forbidden, and, should any persons attempt them, they were warned that they would be considered as perverters and falsifiers of the law. Should any doubts arise, reference was to be made to the Emperor, as the sole legislator and interpreter of the law. ${ }^{2}$

When the Pandects were approaching completion, Justinian decided on the issue of a third work, which should form a handbook for the law-student and ground him in the principles of Imperial jurisprudence as set forth in the two ponderous Codes. Under the name of the Institutes this little treatise soon took shape in four books, being for the most part a remodelled edition of a similar work by a certain Gaius, which had been in circulation for several centuries. This compendium was then announced to the student as furnishing him with as much legal information in a small compass as he could have attained to previously after a four years' investigation of the diffuse compositions to which he was obliged to have recourse. "Take these our laws," said the Emperor, "and study them assiduously, encouraged by the bright hope that your proficiency will one day enable you to govern our Republic in some province which may be entrusted to your care." " At the same time Justinian mapped

${ }^{1}$ Cod., I, xvii, 2, 3; cf. I, xiv, I2. It was part of the scheme that no antinomies or contradictions should occur. Several such, howerer, have been detected by later jurists.

${ }^{2}$ Instit., praf. 


\section{The Age of Justinian and Theodora}

out the work of the class-rooms for legal education, in which the new law books were to supersede all texts previously placed before the student during his five years' course. 'The first year was to be devoted to the Institutes, the next three to Pandects, and the last to the Code. He also directed that the freshmen were henceforward to discard their ridiculous cognomen of Dupondii, and enter on their career under the dignified title of "New Justinians." He also sternly prohibited the rough games which students had been wont to play off on one another, on rude novices, and even on professors, such reckless proceedings having sometimes eventuated in actual crimes. Finally he decreed the abolition of the law schools of Alexandria, Caesarea, and elsewhere, since he had heard that in those places unskilful men with insufficient licence had been engaged in imbuing their disciples with adulterated doctrine. For the future, as previously, Berytus was to be the chief academy of jurisprudence, but the Royal Cities of Rome and Constantinople were also sanctioned to continue as centres of legal instruction. ${ }^{1}$

No sooner had Justinian completed his reintegration of the legal profession than he entered on an active career of new legislation which rendered much of his former work obsolete. The close attention paid to law during the preparation of the l)igest had revealed a number of disputed questions, and these the Emperor determined to decide once for all by virtue of his own Imperial inspiration. When they had accumulated to the number of fifty the list seemed to be exhausted, and thereupon a fasciculus of "Fifty I) cisions" was published to settle the law on these moot points. This supplement seemed to antiquate the Code, 


\section{The Legislation of Justinian}

and hence it was resolved to abolish it in favour of a revised edition, which should be perfected by the inclusion of all more recent legislation. A new Code was, therefore, published in 534 with an injunction that the first should be consigned to oblivion, and never again opened in the law courts.' Still, however, Justinian found an unlimited field for his legislative proclivities, and every year saw the promulgation of new Acts, until his energy began to succumb to senility. Most of the new enactments were called Novels, and many of them were elaborated at great length. For these compositions the Greek language was almost invariably used, but a contemporary Latin translation was made. More than one hundred and sixty of them remain, but some of them are in a fragmentary condition. In addition thirteen other pronouncements, named Edicts, are extant, and also the Pragmatic Sanction, of which an analysis has been given in connection with the anmexation of Italy. Such are the four complements of Justinian's legislation, of which in bulk his own productions constitute about one fifth, but some considerable portion of the latter has probably been lost. ${ }^{2}$

1 Cod., praf., 3. The fifty Decis. are scattered through the Code without clue to their location. One Merillus spent twenty years in trying to solve the crux of identifying them.

2 Some jottings as to the practice of the bar in this age occur in Ammianus, $x x x, 4$; Jn. Lydus, De Magistr., ii, 17 ; and Agathias, iii, I. From the first it seems that there were a great many pettifogging lawyers, who made a practice of fleecing clients by involving them in interminable litigation. 


\section{CHAP'TER XVI}

TIE LAST DASS OF JUSTINIAN: LITER.ATURE AND ART IN THE SIXTH CENTURY : SUMMARY AND REVIEW OF TIE REIGN

T $N$ the spring of 550 , when the five years' truce with

1 Persia expired, Justinian became anxious to effect a further pacification with Chosroes, and Peter Magister, with whose diplomatic work we are atready familiar, was entrusted with the negotiations. The Shah, however, declined to formulate any definite terms at the moment and dismissed him with a promise that he would shortly send a plenipotentiary of his own to the Byzantine Court, who should have full powers to draft a treaty in accordance with the best interests of both nations. He was as good as his word, and the Persian embassy soon arrived at Constantinople, headed by Isdigunas, a man insufferably pompous and arrogant, who brought with him in his train such an $\mathrm{im}$ mense following that he seemed to be advaneing to the battlefield rather than conducting a peaceful mission. He was accompanied by his wife, children, and a brother; and also by two members of the highest Persian nobility, who displayed themselves in public wearing golden diadems on their heads. The Byzantines resented the orerwhelming magnificence of this legation, regarding it as an intolerable assumption of superiority by the Orientals; and they were 


\section{The Last Days of Justiman}

especially indignant when they saw Justinian receiving them with an effusive ceremony which suggested that he conceded everything to their pretensions. These negotiations were protracted over eighteen months, during which the multitude of Persians were allowed to pervade the city with the utmost freedom, engaging in every sort of commerce as if they were natives of the place; and, contrary to custom, subjected to no supervision which might restrain them from gaining information of strategic value. At length a second truce for five years was purchased from Chosroes for two thousand pounds of gold ( $£ 80,000$ ), whilst, as compensation for the cessation of arms since the arrival of the ambassador, a further sum of six hundred $\left(£_{24}, 000\right)$ was agreed upon. The Emperor, judiciously enough, wished to pay by annual instalments, so that he might retain a pledge in his hands to ensure the faithful observance of the compact, but the idea was abhorrent to the Byzantine populace, who considered that they should thus become tributaries of the Persian monarch. The amount was, therefore, paid down in full, and Isdigunas returned home, the bearer on his own part of a splendid pecuniary gift from Justinian. ${ }^{2}$

In the meantime the subsidiary war in Lazica went on continuously, as Chosroes was unwilling to relinquish his hold on the principality, and professed that his pacific engagements did not apply to that outlying region. Thus the capture of Petra by Bessas, as already related, was an occurrence of the same year as the renewal of the truce with Isdigunas. After those events the Persian occupation was still maintained by Mermeroes, who had already been many years in the country, and contested the supremacy of the

1 Procopius, De Bel. Goth., iv, I I, I5. 


\section{$72 S$ The Age of Justimian and Theodora}

Byzantines with varying success. His most notable effort was the siege of Archaeopolis, the capital, in 550, when, after many strenuous attempts, he tried to capture the town by bribing one of the natives to fire the gramaries. Ite thought by this means to divert the attention of the small garrison from the walls, so that the attacking force should be unresisted while effecting an entry. Contrary to expectation, however, the Byzantines were just prepared for a sally; and, leaving a few of their number within to extinguish the flames, they burst out suddenly on the besiegers. 'The latter, taken by surprise, suffered such loss that Mermeroes forthwith raised the siege and retired to another part of the country:

Mermeroes died in 554 , and was replaced by Nachoragan, whose career was short and unfortunate. In the following year he essayed the siege of Phasis, a town by the sea at the mouth of the river of the same name. He had an army of sixty thousand at his disposal, while the Roman forces, under Martin and Justin the son of Cermanus, did not amount to a third of that number. As the town was built of wood the Persian general expected an easy conquest, and resolved to destroy the walls by fire. On the south, where not defended by river and sea, an external mumiment had been improvised in the shape of a fosse, filled with water from an adjacent lake, and a palisade. On the water were stationed a number of ressels with baskets fixed to the mastheads; and from these, as from towers, darts and missiles were shot or hurled. 'The Orientals, who had rendered their line of blockade continuous by a bridge of boats across the Phasis, were provided with elephants, having 


\section{The Last Days of Justinian}

towers on their backs, and had constructed machines for attack of every description. After a few days' work the fosse had been levelled up to the ground by the ingestion of various materials; and Nachoragan, at the outset of a determined assault, said to a band of two thousand pioneers whom he was despatching to a neighbouring wood to bring up further supplies of timber, "When you see the smoke rising you will know that the Roman defences are in flames, and may hasten back to aid in the work of destruction." On the morning of the same day Justin, by a divine inspiration, as we are told, had stolen out of the town with five thousand cavalry and a brigade of infantry, in order to pray at a church of great sanctity in the vicinity. Subsequent events now become shaped by a prior incident which I have next to mention. Fearing that his men might lose heart by comparing the paucity of their numbers with the multitude of the enemy, Martin had a few days before caused a travel-stained messenger to arrive ostentatiously amid a concourse of the soldiery and hand him a letter, which he opened and read aloud. The missive purported to come from the Emperor and to convey a notice that large reinforcements had arrived within a score of miles and would shortly join the garrison. "Tell them," said he, with assumed indignation, "that their aid is not required: just as we are about to discomfit the enemy, their coming will snatch from us the glory of victory." The ruse succeeded; his action was acclaimed by the troops; and not only were they inspirited, but some anxiety was communicated to the besiegers, to whom the affair was reported, and a considerable body of men was detached to watch the route by which the visionary army was expected to arrive. The Persians attacked vigorously on the land side, and were resisted with 


\section{The Age of Justinian and Theodora}

equal energy by the Byzantines. A great clamour arose, and Justin, on the return from his pious errand, became aware that a fierce battle was raging. He found himself in the rear of the assaulting force, when, with sudden determination, he ordered his ensign to be raised and charged the enemy in the back. The Romans routed those upon whom they swept down, and a panic quickly spread through the Oriental troops. The army of relief, whose propinquity had been credited, was assumed to be actually present, and a general flight ensued. Justin followed on hotly, and ten thousand of the Persians were slain before the pursuit was abandoned. At last he collected his men and returned to Phasis, where all the siege engines now appeared, scattered around, as deserted by the enemy. Their destruction by fire was at once resolved upon, and the column of smoke rose in proximity to the walls. To those engaged felling timber in the distant wood it seemed to indicate the consummation of their general's designs; whereupon the two thousand pioneers at once threw down their implements, and hastened impetuously to the town, fearing to be too late to deserve a share in the predicted success. Thus they unwittingly ran into the arms of the Byzantines, who slaughtered them to the last man.' As soon as the news of this disaster was conveyed to Chosroes he was filled with rage against Nachoragan, whom he immediately recalled and ordered to be flayed alive. His skin, torn off in one piece from head to foot, so as to retain the shape of the body, was sewn up and inflated like a bladder; and then suspended from the summit of a lofty rock to signalize the fate which should befall anyone who fled before the enemies of the Shahinshah." 
Among the most notable incidents during this period of the war in Lazica was the affair of King Gubazes. The mother of that prince was the daughter of a senator, and before his succession he had borne arms for some years as a silentiary at the Byzantine Court. Shortly before the death of Mermeroes, owing to an error of judgment on the part of the Roman generals, a section of the army had been severely handled by the Persians; and the Lazic king had taken upon himself to report the matter to Justinian as resulting from the incapacity of his officers. Martin and two of his subordinates, the brothers Rusticus and John, were those chiefly concerned; and in their minds much animosity was excited against Gubazes. They concerted a plot, therefore, to encompass his death; and John made a special journey to Constantinople with the object of accusing him to the Emperor. Owing to his former defection to the Persians, Justinian was easily persuaded that he was again meditating a similar treachery; wherefore he ordered that he should be arrested and brought to the capital for interrogation. "But," queried John, "should he resist your mandate?" "Then," said the Emperor, "you may kill him as an open enemy." Armed with this authority in a written warrant John returned to Lazica; and the brothers at once sent Gubazes an invitation to meet them at a certain spot, using as a pretext that they wished to confer with him as to an attack upon the Persians. Unsuspectingly the King advanced with a few unarmed followers to the place indicated. With the knowledge of the other generals, who contemplated merely an arrest, Rusticus and John, accompanied by an armed band, proceeded to meet him. The plotters, however, knowing that an interrogatory would reveal their treachery, had it in their minds to provoke Gubazes by an 


\section{The Agre of Justiman and Theodora}

altercation, and then to assassinate him in pretended compliance with the terms of their warrant. The parties met, and the brothers challenged the King to join them in an expedition against the common enemy. But be declined, saying that, until they had retrieved their errors and proved themselves to be capable leaders, he would not follow them to the battlefield. This attitude was taken as sufficiently evincing a determination to resist the Imperial authority; and John struck him with his sword, causing him to fall from his horse. 'Then as he lay on the ground, at the bidding of Rusticus, some of the guards standing by consummated the murder. ${ }^{1}$

'This foul deed aroused the utmost indignation among the Iazi; and the nation decided forthwith to transfer their allegiance to the Persians. A public debate, however, was held, at which moderate counsels ultimately prevailed; and it was resolved to send delegates to demand justice of the Emperor. On their arrival at the Court they asserted the criminality of the assassins, and defended Gubazes from their imputations. 'They also solicited that Tzathes, his younger brother, then resident in the capital, should be appointed King in his stead. Justinian accepted their assurances and acceded to their request; and he at once commissioned Athanasius, a senator of the highest rank, to proceed to Lazica in order to bring the culprits to trial. A judicial court was constituted in public with great pomp to impress the natives; the senator occupied a lofty throne surrounded by guards and legal assessors, and Rusticus and John were produced loaded with shackles. Adrocates of the Iaxi, who were versed in Greek, conducted the prosecu-

1 Agathias, ii, 2 el seq. 


\section{The Last Days of Justmian}

tion, and demonstrated that the innocence of Gubazes was beyond question. The written commission of Justinian was read, by which it was shown that only armed resistance to arrest would have justified what was done. The prisoners made an elaborate defence, asserting, but without a shadow of proof, that the King had been a traitor, and maintained that they had acted with the cognizance and assent of Martin. Athanasius summed up the case calmly, and concluded that Gubazes was acting within his rights when he refused to join the proposed expedition in view of the adverse opinion he had formed as to their military competency. $\mathrm{He}$, therefore, pronounced the brothers to be guilty, and condemned them to be decapitated. They were forthwith mounted on mules, and paraded to the place of execution, whilst a herald announced their delict and proclaimed the supremacy of the laws (555). As to Martin, his complicity was not investigated openly, but it was considered prudent to supersede him in his command, and relegate him to a private position. Justin was then appointed to be principal general in Lazica." After this date the Lazic war flagged, and within a year or two the two monarchs gladly agreed to a cessation of arms, with the understanding that each was to retain those positions in the country of which they happened at the moment to be in occupation. ${ }^{2}$

1 Agathias, iv, I $c t$ sey.

2 Ibid., 3o. An incident in the Lazic war may serve to illustrate the usual manners of the soldier of the period. A band of forty beset a mountain fortress inhabited by a tribe in league with the Persians. It was called the Iron Castle from its supposed impregnability. A single rocky path, steep and narrow, led to the gate, where some huge stones were poised, capable of sweeping the track from top to bottom in their downward course if set in motion. In the darkness of the night, the Romans essayed the capture. Eight sentinels were seen at their posts,

II. 


\section{3.t The Age of Justinian and Theodora}

The defence of the Manubian frontier against the scarcely remittent barbarian raids was very ineficiently maintained, at least during the latter years of Justinian's reign. Hence the safety' of life and property in 'Thrace and Illyricum was in continual jeopardy. In 549 the Slavs were first enholdened to cross the river, when a horde of three thousand rushed headlong against the Roman forces, whom they utterly routed, though considerahly more numerous than themselves. 'They then pursued their course, devastating the country mercilessly, until they arrived at 'Poperus, a town of sixty thousand inhabitants, and the most important scaport of 'Thrace. Hy a ruse they enticed the garrison to make a sally, and, having massacred them, soon captured the town by means of scaling ladders. The whole adult male population, amounting to fifteen thousand, was slaughtered, and the women and children were reduced to servitude. The Slavs then returned to their own abodes, leaving their track littered with the unburied corpses of their victims, whom it was their custom to kill by transfixing them to the ground by means of stakes driven through their bodies.'

lut all asleep. One of the ascending party slipped and made a racket with his wiehd, which nused the suards, who snatched up torches and gazed in every direction. Lut the Romnans stood stock still, and escaped notice in the dark. The sentincls returned bo their slumbers, and were at once atracked and slain. The Komans then siuted through the town, set lire w the houses, which were of wool: massacred wonen who courried around; eren a lady of rank. jewedled and elegantly dressed,

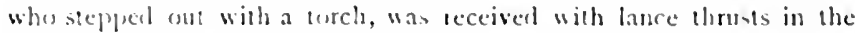
alxtromen; children were flung into the air and eranofied lyy lecing caught on the proms of pites: until alt secmed on lee exterminated. The ligrantines then rester carclessly, as ansured of safety, but the enemy collected from another quarter and, olmerving their fewnens, killed nearly all lyy an unfursecen attack; Agathias, iv, $15 \mathrm{csc}$.

'Irocopius, I)e liel. (inll., iii, 3 S. It was about this time, after the 


\section{The Last Days of Justinian}

Less than ten years later a populous nation of barbarians, the Avars, appeared on the west of the Caspian, who were destined during the next couple of centuries to become troublesome enemies of the Byzantine Empire. Justin still held the chief command in Lazica, and to him they made overtures that they should be received into the Roman alliance. He forwarded a chosen legate, Candich by name, to Constantinople, who boastfully informed the Emperor that he belonged to the greatest nation of the earth, who were capable of annihilating all his enemies. But they demanded rich presents, a yearly subsidy, and the bestowal of a fertile region for them to inhabit, before they entered the service of the Empire. Justinian, as the historian informs us, was now broken by years, and there remained to him little of the force of mind which he had displayed when he conquered the Vandals and Goths. He was tired of war and desired to avoid it by any pacific means. He at once accepted the suggestion of the Avars, and despatched an ambassador to them, the bearer of golden chains, silken vestments, and numerous other costly gifts, which Justin was instructed to distribute judiciously and to direct the hostilities of the recipients against various turbulent tribes. This was done effectively, and severe chastisement was inflicted in many quarters. The Avars, however, refused a

death of Theodora, that John of Cappadocia returned to the capital, but he had fallen into too great disrepule to be reinstated in any creditable post by the Emperor. Being reduced to great poverty, he found that at last he must take seriously to the priesthood. At the ceremony of his ordination, not having a decent cassock, a monk named Augustus, who was standing by, lent him his garment. Shortly it was noised through the city that the prophecy as to John's exaltation had been fulfilled, and that he had now really "assumed the mantle of Augustus"; De Bel. Pers., ii, 30 . 


\section{The Age of Justinian and Theodora}

grant of land in Pannonia, as being too distant from their ancient seats. Subsequently the Chagan, such was the title of the Arar chicf, sent a mumerous deputation to the capital, but, after long detention, they were dismissed without definite result. Their strange appearance was one of the spectacles of the city at this time, and the populace wondered at their long hair, plaited and tied up with ribbons. During their stay they took the opportunity of purchasing a large quantity of arms, and the Emperor notified Justin that they must by no means be allowed to inport these safely into their own district. The weapons were seized, therefore, while in iransit, by the military; and the circumstance was the origin of the bitter hostility which was afterwards displayed hy the Chagan and his subjects towards the Empire.'

In 559 the most alarming barbarian insasion which occurred during the reign of Justinian, is recorded. \%abergan, an enterprising Hunnish leader, conceved no less a design thin to subvert, or, at least, to pillage the whole Eastern Empire. The statement suggests the irruption of a rast horde of barbarians, who would spread themselves far and wide over the country and swepe everything lefore them in their destractive course; but such was the deplurable condition of the defences of the Empire, that this buld scheme was undertaken with an army which could scarcely have exceceded fifteen thousand horse. With this force Habergan crossed the llanube on the ice in the month of Mareh, and when be hat penetrated the interior for a sufficient distance, divided his army into three sections. 'l'o the lirst was allotted the conpuest of firecee: the serond was impelled towards the Thracian ( hersonnesus, from whence it was contemplated

Menander, Legat., i; Theophanes, an. (n) 50 


\section{The Last Days of Justinian}

that it should pass the Hellespont and overrun the Asiatic provinces; whilst with the third division, consisting of seven thousand cavalry, the leader advanced against the metropolis. This plan of campaign was entered on without hindrance, as the provinces were almost destitute of soldiery, Those of the military who were in an opulent position abandoned themselves to dissipation, devoting their time to the Circus, the theatre, and courtesans, while the rank and file of the army deserted the colours and tried to make a living as civilians. Such was the result of the conduct of the paymasters and commissaries, who embezzled the funds apportioned to the military establishment; and here again, as a second historian tells us, the senile ineptitude of the Emperor was manifested. As Zabergan pursued his course the districts through which he passed were devastated savagely on every side. Private mansions and convents were broken into, women of all classes were seized and subjected to the brutal excesses of his followers, and infants were scattered about the fields to become a prey to dogs and vultures. The Long Walls were dilapidated, and even those of the city itself; the damage being chiefly the effect of earthquake shocks, which had been severe during recent years. The barbarians passed through the former, therefore, and encamped on the river Athyras, less than twenty miles from Constantinople. In the meantime the capital became filled with consternation, which was increased by crowds of fugitives who rushed thither from the outlying tracts. From the Golden Gate to Blachernae the suburban churches were emptied of their precious ornaments, cartloads of which were borne within the walls. There was no regular garrison to occupy the battlements; the Scholars and other Palace guards, who had been ordered out to defend the Long Walls, fled at the sight of the enemy, and the 


\section{The Age of Justinian and Thiodora}

multitude of civilians and rustics were devoid of military instinct and unable to wield the weapons which were supplied to them; nor had the government a single officer with the slightest capacity for active warfare at their disposal. In this strait the Emperor found that he had no resouree but to commission Belisarius to undertake the defence of the city. The veteran general, long unemployed, had already' succumbed to age and infirmity, but he obeyed with alacrity, and again appeared in the martial attire which he seemed to have laid aside for ever. With difficulty he collected three hundred soldiers of those who had served under him in his wars, and with these as his main force, he proceeded to employ as effectively as possible the unwarlike rabble. They were instructed to post themselves behind a long trench which he caused them to excavate, and numerous fires were lit to indicate the presence of a great host. At the approach of the enemy they were also enjoined to raise a huge din by clashing together their swords and shicks. Zabergan, however, was led to suspect the real state of the defenders, and directed a mass of two thousand cavalry to make an impetuous dash against the Byzantines. Belisarius, forewarned, divided his veterans into three equal bands, one of which he retained about his own person, whilst the others were concealed in the woods, so as to attack the enemy on the flanks as they passed. 'These tactics were put into practice effectively; the general charged the Huns in front as soon as they came in sight, and simultaneously the ambushed troops fell on them from each side. In inmediate rout of the barbarians was the result, and they fled back with all speed to their own (amp. Four hundred were slain in the pursuit which ensued, whilst among the Romans no single life was lost. When belisarius returned to Constantinople he was acclaimed as a 
saviour by the populace, but from the magnates of the bureaucracy he experienced nothing but repellent looks and invidious utterances, and he relapsed at once into the obscurity from which he had emerged for the moment like a meteor. ${ }^{1}$

As for the further efforts of Zabergan's expedition, they may be dismissed in a few words. At the Pass of Thermopylae the Huns were brought up by a wall from which they were repulsed by the garrison; and at the entrance to the Chersonnesus their career was similar checked. In the latter case, however, they constructed a fleet of rafts, by means of which six hundred of them tried to land on the peninsula from the waters of the Hellespont; but they were attacked by a number of Byzantine galleys during their perilous navigation, and almost all perished by drowning. Ultimately the survivors of both failures rejoined their leader, who still maintained his ground and proclaimed that he would not quit the Roman soil until he had been paid a large sum in gold. His captives were then reviewed and assessed at so much a head, and with the ransom thus accumulated Zabergan retreated to the Danube. Justinian, however, was determined to prevent his escaping at so little cost to himself; and he forthwith despatched an emissary to Sandichl, chief of another tribe of Huns, who had been heavily subsidized for guarding the approaches to the Empire from the north. Having upbraided him for negligence, he informed him that the funds which should have been his had now been paid out to Zabergan, wherefore he must be satisfied to lose the amount unless he could recover it by force. Hence an internecine war broke out between the two tribes,

1 Agathias, v, I I, et seq. 


\section{ito The Age of Justinian and Theodora}

who were named Cigurs and Cotrigurs respectively, in the course of which they mutwally destroyed each other, much to the advantage of the Byzantines.' At the same time a fleet of biremes was sent up the Danube to assist in the retaliative operations. Soon after the departure of the enemy, a great conconrse of eitizens, with the Emperor himself at their head, although now probably in his seventy-seventh year, went out from the capital to survey the Long Walls; and Justinian continued to reside in the vicinity all the summer engaged in supervising the restoration of that bulwark."

In 562 a definite and comprehensive treaty was at last concluded with Persia, by which Chosroes agreed to relinquish all claim to Lazica in consideration of an annual payment of thirty thousand solidi $\left(E_{1}, 000\right)$. 'This peace, which was to remain in force for fifty years, was the final diplomatic achievement of Peter Magister, who died soon after, on his return to Constantinople." Juring the next year Justinian undertook a pilgrimage to Myriangeli, a holy place in Galatia, at a distance of threc hundred miles from the capital, being the longest joumey he had made since he mounted the throne." On his return, octogenarian though he was, a conspiracy to assassinate him was promoted by some officials who had access to the l'alace, but the design was betrayed by one of the associates of the plot. Many arrests were made, and some of the prisoners tried to save themselves by pretending that they had merely been suborned by Belisarius. The general was summoned before the Imperial council for interrogation, and, although there was no evidence to sub.

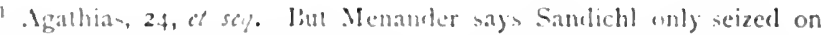

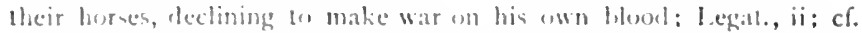

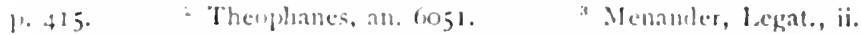
1 Therphanes, an. 6056. The chomology seems to he mudilied here. 
stantiate the accusation, he was degraded from his rank and ordered to be detained as a prisoner in his own mansion. ${ }^{1}$ This formal incarceration was not relaxed for over six months, but at last Justinian became persuaded of his innocence and allowed him to resume his position at Court. ${ }^{2}$ About eight months afterwards the great soldier died, having had nothing but disregard and ingratitude for his lot during the final years of his life, but there is no foundation for the story of later centuries that he was actually reduced to indigence and used to sit as a mendicant in the streets of Constantinople, protesting his blindness and begging a copper of those who passed along. ${ }^{3}$ After his death, we read that his fortune was raked into the coffers of the state, ${ }^{*}$ whence it is inferred that his daughter Joannina, the only relative he is known to have possessed, must have predeceased him. The death of his stepson Photius is mentioned as having occurred a decade or so previous to his own, ${ }^{5}$ but his wife Antonina, notwithstanding that she was so much his senior, appears to have long outlived him and to have ended her days in the odour of sanctity. It is recorded that the pious widow went to live with Vigilantia, the sister of Justinian, and at her suggestion restored a church which had been destroyed by fire. ${ }^{6}$

In the closing scene of his life Justinian is exhibited to us as agitated by his ruling passion, devotion to theological subtleties, and as expending his last breath in an attempt to impose on the Church a heresy which he had rejected

1 Jn. Malala, p. 493 .

3 Codinus, p. 29 (from Banduri).

${ }^{5}$ John Eph., Hist. (Smith), loc. cit.

${ }^{6}$ Codinus, p. I08. On her return to Constantinople after the death of Theodora, Antonina broke off the match with Anastasius, although, in order to make sure of the alliance, the Empress had caused the young people to cohabit during their betrothal; Procopius, Anecd., 5. 


\section{7t2 The Age of Justinian and Theodora}

when his faculties were more acute. With one foot in the grave he became convinced that the Aphthartodocetae or Incorruptibles had arrived at the true view as to the properties of the flesh of Christ; and the octogenarian Emperor embarked on the enterprise of elevating this tenet to the rank of an Orthodox dogma. The resistance of Eutychius, the Patriarch of Constantinople, who had presided at the Fifth General Council, was punished by expulsion from his see; and Anastasius, the Jatriarch of Antioch, was threatened with a similar fate. 'To enforce conformity with the Emperor's most recent conviction an edict was prepared, which would have excited a commotion among the Orthodox communions throughout the Empire, but its issue was prevented by the unexpected death of its author."

Justinian died in November, 565, at an early hour of the morning, in the thirty-ninth year of his reign, and the eighty-third of his age." The news was at once conveyed to the Senate, who forthwith aroused Justin, the son of Vigilantia, and besought him to accept the Crown. He occupied the post of Curopalates, or intendant of the Imperial household, and his succession had doubtless been privately arranged for sonse time previously. After his formal acquiescence the funcral rites of the deceased monarch were the first care. The body was placed upon a golden bier in a hall of the Palace, and sophia, the wife of Justin, and a niece of 'Theodora, herself enshrouded it in a purple robe, on which were pictorially embroidered all the great events of Justinian's reign. by sumrise the ferople had become informed, and the assemblage in the Ilippodrome followed in accordance with time-honoured precedent.

'Evagriu, is, 39, ct sey, ; Eutathius, Vit. Eulychii, etc.

- Theophanes, an, 6057 , cic. 


\section{The Last Days of Justinian}

Justin appeared, was acclaimed and hoisted on a buckler, and all the customary preliminaries of a coronation were enacted. The new Emperor made a speech, in which he promised to reform all abuses, and gave a practical earnest of his intentions by announcing that his uncle's debts would be paid forthwith. A band of notaries, accompanied by a gang of porters bearing bags of gold, then entered the arena, and all creditors who presented themselves had their accounts settled. The completion of the obsequies was the next duty to be accomplished. The people thronged the hall where the corpse lay in state; the bier was lifted up and borne away amid a crowd of mourners carrying wax lights, and a choir of virgins who intoned hymns as the procession moved along. The Church of the Holy Apostles was its destination, and when that edifice was reached the body was deposited in a golden sarcophagus which had been prepared for its reception by Justinian himself. A popular festival followed; the city was decorated with flowers, fruits, reeds, and olive branches; a variety of musical instruments resounded from every quarter amid popular applause and rejoicings; and the reign of Justin II was inaugurated with all the illusive hopes which foresaw the return of the Golden Age in the accession of the new monarch. ${ }^{1}$

${ }^{1}$ The funeral and coronation scenes are described by Corippus in his poem, De Land. Justini Min., i, 226, et seq., iii, 28, et seq., etc. Theophanes Byz. mentions a general of the East, "Theodore, son of Justinian," who is generally supposed to be a son of the Emperor by a concubine after the death of Theodora. Procopius gives an account of a youth whom the latter was attached to, but treated cruelly. He seems, however, not to have been a lover, but merely a protégé; Anecd., 16 . Justinian figures in Dante's Paradise (vi), and has a whole canto to himself. He summarizes Roman history both before and after his own times, and confesses that he owes his salvation to having been converted from Monophysitism by Pope Agapetus. 


\section{4t The Age of Justinian and Thiodora}

With respect to literature and art in this age, a few remarks may be added to what has already been said upon the subject in a previous chapter of this work. But in relation to the productions of the Eastern or Later Roman Empire, the words literature and art must be used in a modified sense, because there were no Byzantine classics and no artistic masterpieces. Greek poetry ended with Memander and Theocritus, nearly three centuries before the Christian era; the last I atin poet was Claudian, who flourished more than a century before the time of Justinian. During the succeding millennium, however, there were many rersifiers at Constantinople, but no poet. Yet we could rarely spare their works, as they are often valuable for the historical or other information which they contain. As regards prose, of course, the position is different; for in that domain highly meritorious works can be produced without the aid of genius. The chief Byzantine writer there is Procopius, to whose compositions, considerable in bulk as they are, we are indebted for almost all detailed history of the sixth century. He was, as we have seen, for the most part the companion of Belisarius in his wars, not in a military capacity, but as a civil adjutant; and hence he is generally describing events in which he himself took an active part. He appears to be alsolutely truthful, and it is improbable that he has given currency to any deliberate falsehood. In recondite matters he is sometimes corroborated by other historians, and he has never been contradicted.' Close critics of his text are able to point out that he used Herodotus and Thucyclides as his models." He was a man

1 sec p). $345,345,441,442,454,620$.

- A fallacy seems io have gained curtency that l'rocopius is pedantic lecause he nealy always calls Constantinople Byzantium. He could 


\section{Literature and Art in the Sixth Century 745}

of abundant common sense, well informed for his epoch, and less superstitious than any typical specimens of his contemporaries. In religion he was a freethinker, believing in a Providence, which, however, had not become concrete in the form of any personal being in his mind. ${ }^{1}$ When making use of previous writers he adopts their accounts with little discrimination, though he sometimes suggests that the reader may disbelieve if he sees fit to do so. ${ }^{2}$ Three terms

not do otherwise without being singular: the new name is scarcely ever used, except in official documents and ecclesiastical writers. It is to this persistence of the original title of the city that we owe the survival into modern times of the epithet Byzantine. etc.

${ }^{1}$ See p. 514; cf. De Bel. Pers., ii, 9, I0; De Bel. Goth., i, 3,

2 The general ignorance of this age is well illustrated by the ridiculous account Procopius gives of Britain; De Bel. Goth., iv, 20. The island, he says, is divided longitulinally by a wall on account of the diversity of climatical conditions which prevail on the different sides. To the east the country is genial and salubrious, fertile with corn crops and fruit trees, and thickly populated. But on the west of the wall everything is the contrary, and no man could exist there, even for half an hour. The region is thronged with vipers, serpents innumerable, and poisonous beasts. And, what is hardly credible, if anyone should cross the wall, he at once succumbs fatally to the pestilential air-as the natives relate. But he thinks it must be altogether a fable when they say that the villagers on a certain part of the Gallic coast, who live as fishers and farmers are absolved from payment of taxes on condition of their ferry. ing the souls of the dead across the ocean to this adjacent isle of Britain. In tempestuous weather, at the dead of night, they are summoned from their beds, and have to rush to the sea-shore. There they find numbers of apparently empty boats. They have to seize the oars and row for a day and a night. When they start, the vessels are weighed down to the water's edge, but on returning, they are so light as barely to skim the surface. Yet all the time they see no one; but when landing the souls, they hear a voice calling out the names and titles of each of the deceased.

Procopius also makes an excursion into British history, which is, 


\section{$7+6$ The Age of Justimian and Theodora}

may be distinguished in his literary career. During the first, which extends to about $55^{\circ}$, he was actively engaged in the Persian, Vandalic, and Gothic wars, and wrote his account of them in seven books. In the meantime he had opportunities of becoming intimately acquainted with the system of govermment and personality of the bureaucracy; and his observations led him to feel a strong repugnance for the administration and all comnected with it. In the second term he resolves to register in a secret work his adverse conclusions and private information respecting the actors in the scenes which were passing around him, in the hope that it may lead to their being one day shown up in their

perhaps, no more authentic than his ghostly narrative. The Franks, he informs us, claimed some extent of suzerainty over the islaud, and when they sent a legation to Iustinian in 54 , they included, for the sake of ostentation, a number of Angles in the party. IIe goes on to relate that a prince of the Varni, a nation occupying lands to the north of the Khine over against Britain, had betrothed his son kadiger to a British maid, the sister of the King of the Angles. 1le had himself recently taken, as his second wife, a sister of Theodebert, the lrankish monarch. Soon afterwards, finding himself on his death-bed, he exhorted his son to marry his step-mother, a connection permilted by their law, as lecing more to the interest of the Varni than the British alliance. On his father's decease, Kadiger obeyed these instructions, whereupon the British princess, indignant at being jilted, assemblesl an army of one hundred thousand, under one of her lirothers' generalship, and invaded the country of her faithles lover. I'rocopius explains that all this force cunsisted of infantry, since the islanders had never even seen a horse. A great batle wins fought, in which the Tami were defeated and put to tlight. Kadiger being taken prisoner, was hrought before the matial princes, who reproached him severely for his conduct towards her. He excused himelf by pointing oul the varinus necessitics which had weighed upon him, but expressed his presene willingness to fulfil his firs contract of marriage. llincoffer was accepted, and ultim. ately the muttials of kadiger and the English princess were peaccfully uslemnizacl ; irit. 


\section{Literature and Art in the Sixth Century 747}

true colours for the common benefit of humanity, when the dangers of such a publication shall no longer exist. ' In 550, therefore, he writes his Secret History or Anecdotes, which he anticipates will attain the desired end. ${ }^{2} \mathrm{He}$ then turns his attention to the more recent operations of the Persian and Gothic wars, in which he had not himself borne a part, and describes them by adding an eighth, and final, book to his historical compositions. Gradually his literary work becomes generally known, and its merit recognized; the Emperor himself becomes one of his readers, and concludes that Procopius is the historian by whom his name will be handed down to future ages. He becomes personally interested in him, and the third term sees him enjoying the sunshine of Court favour. Justinian, proud of his extensive building achievements, is anxious that his activity in this sphere shall not perish in obscurity, and employs the historian to compose a work in which all his notable archi. tectural works shall be described in realistic detail. For this compilation the Emperor himself affords information, and has the book written under his own eye in the flattering style usually adopted by courtiers when referring to the sovereign. Procopius, not indifferent to material advantages, complies with established formalities, and receives the meed of his talents and industry from the Emperor impersonally, as the state official who acts as the deputy of the public. Later on he is promoted to the post of Praefect of the City;

1 Anecd., praef.

2 He mentions (Anecd., I $8,23,24$ ), that he is writing thirty-two years after Justinian came into power, meaning $5 \mathrm{I} 8$, the date of the accession of the superannuated Justin; see p. 304. The credit of pointing out the very obvious fact that Procopius ignores Justin as a cypher, is due to Haury, Procopiana, Augsburg, I891. 


\section{The Ase of Justinian and Theodora}

and it falls to his lot to become custodian of his former chief when arrested on suspicion of conspiracy.' He had no biographer, and of his private life and connections nothing is known except that he was a native of Caesarea, in Palestine. ${ }^{2}$

As literature, all other Byzantine authors are practically negligible, but their value as sources of historical information has been sufficiently evidenced in the course of this work. It no subsequent period did a second Procopius arise, but a few words may be said about his immediate continuator, Agathias. He was an adrocate by profession, in modern phrase, a briefless barrister, whose tastes were literary rather than forensic. He attempted poctry with slight suecess, and finally hoped to find his rocation in writing history in emulation of l'rocopius." Not being a man of action like his predecessor, nor occupant of a post which enabled him to base his narrative mainly on personal exIrerience, he wrote as a student rather than as an observer of erents. He is thus better acpuainted with books than with men, more widely read than l'rocopius, but studical, diffuse, deficient in personal convictions, and lacking in historical insight. His short history, which was interrupted by death, is, however, invaluable as heing a sole: source: and it is unlikely that, had he not undertaken it, anyone else would have filled his place and done it betler."

1 In. Malala, loe cit. The name was not uncommon, se thet the jelentibatun in conty highly probahle.

- Ix liel. l'es.., i, 1 .

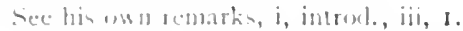

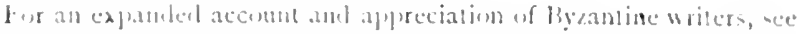

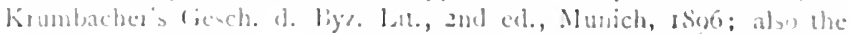




\section{Literature and Art in the Sixth Contury 749}

The sixth century in the West was not altogether an age of darkness and ignorance, but was illuminated by two writers - who have already been mentioned as intimates of Theodoric-Cassiodorus and Boethius. The latter was a voluminous and able author; and his Consolation of Philosophy, composed in the prison from which he was released only by a death sentence, is well known to modern readers, and has every title to rank as one of the Latin classics. Cassiodorus, also a prolific writer, though of no great talent, is important in the world of letters as having been the founder of literary monkhood, which he originated in a monastery erected by himself at Squillace, whither he retired after his political career. ${ }^{2}$ He is understood to have survived there for thirty years, and almost to have become a centenarian in the enjoyment of learned leisure. St. Benedict also flourished in the first half of the sixth century; and the well-known order instituted by him, the Benedictines, ultimately took up the work initiated by Cassiodorus, and produced some of the most erudite contributors to knowledge of the ancient classics.

When treating of Byzantine art the question must always arise whether that term can be applied to productions which in previous or subsequent ages would not have been accepted as competent work. The renaissance of art in Italy is a phrase virtually synonymous with emancipation from Byzantine methods, but the latter, as already explained, ultimately became rooted in a conventionalism which was

introduction to Diehl's Justinian, and his Études Byzant., 1904. Useful summaries and jottings on various points are also to be found in the appendixes to Bury's Gibbon, especially rol. iv.

${ }^{1}$ See his tracts for educational purposes, some of which are referred to on p. 212.

II. 


\section{The Age of Justinian and Thcodora}

not typical of carlier efforts.' In the time of Justinian there is no evidence that painting and sculpture in the higher sense existed at all. We know of no pictorial representations, with the exceptions of miniatures in manuscripts and mosaies on the walls of sacred edifices, while the glyptic art secoms to have been almost confined to columnar capitals and carving on plates of ivory: ${ }^{3}$ Of the former class it can mly be said that all specimens are not bad, of the latter that there is some meritorious work.

The Byzantines were great builders, and in this sphere alone are their artistic creations really worthy of considera-

'See Igincourts pictorial series, which exemplifies the perfecuon of Greck and koman art, traces its lecay, and finally illustrates its rehabilitation in the tifteenth century. In I)iehl's fusinian there are many excellent photugraphs of sivth century productions.

$\because$ The muace of kavenna can be examined in the South kenington fresiniles, and their coutly recognized hy comparing them with modern work of the same kind executed on the walls of the museum. One of the faces in these tableaux, that of Maximian, bishop of Kavenna, whe sand- besiles funtinian, given the impression of being a faithful likenes; wheh is probalile, since the work was executed under his own super. vision (c. 5.45). This was a man of some force of character, who gaincel consilerable repule in his day. Of him an amuing story is fold: it in sad that he di-covered a great treasure, which it was his duty to hand over to the Emperor, tue, a be wished to retain a pertion for his charit. alse whigations, he hit on the following expedient. Having killed an ox, he emptied the ablomen and stowed a quantity of the gond inside. He then wetk a pair of bnots and filled them with a further amount. With the ret of the treasure he set cut for Constantinople and, on his arrival, frenemed it to gutinian. The Autorater immediately inquired, "Is thi the whole of what you discovered?" ".1ll," sail Maximian, "cxcepte what I put in the leelly and the Inote" ly. this answer he is sup. preed to have heralwinhed the limperer, who imagined him to allude merely to his smsterance and travedling expenses while on the roat: Agnellus, lib. l'ontuf., m liha.

There is one very fleasing exanple, the well-kmonn diptych of the archangel Michael in the Briti-h Musem, hut it secms of unique merit. 


\section{Literature and Art in the Sixth Century 75I}

tion. The features of classical Greek architecture, which with certain variations subsequently became Roman, are familiar to all. A Hellenic city of the best period was a chaste arrangement in white marble, in which the simplicity of the straight line was applied to define the form of all public buildings. Rows of accurately proportioned pillars, supporting a continuous entablature, invested both edifices and open spaces, and formed sheltered colonnades which were a defence against extremes of weather at all seasons. The architectural conception originated at some time far back when timber was the only material used for construction. Geometrical curves were rarely if ever seen, except in fluted columns, but the diversity of form to be found in the undulating lines of nature was profusely represented by foliaceous capitals, and in pediments, friezes, and metopes sculptured with the various figures of animal life. The Byzantine Greeks, however, completely reversed the conceptions of their ancestors, and abandoned the purity of classical style. Interest in form was gradually lost along with the capacity to execute it; and the taste of the age found its refuge in an overwhelming attachment to diversity and brightness of colour. To satisfy this craving recourse was had to variegated marbles, of which lavish use was made, for pillars in the mass, and in thin slabs for mural decoration. For the latter purpose also every available space was invested with glaring mosaics, the gaudy hues of which compensated for the absence of grace and natural proportions in the gaunt figures with which they were crowded. But these methods were applicable only to interiors, whence the building itself came to be considered as merely a packingcase into which was to be stuffed the wealth of meretricious adornment. Thus a temple, that is a church, became a 


\section{The Age of Justinian and Theodora}

ponderous and shapeless mass of brickwork, with an alpearance appropriate, perhaps, to a harrack or a barn, instead of being a civic ormament of light and beaty. The komans had the secret of a form of construction other than the continued entablature, and were attached to the method of sustaining superimponed masses by necans of the arch, akin to which was the dome, which they probably adopted after their arms had penctrated to the last. On the liber, therefore, the straight entablature began to be displaced by a series of arebes: and vaulted roofs were occasionally secn under the first emperors. In the new Byantine architecture, which orininated, or, at least, came to maturity under Justimian, both these methods of building were developed to the fullest extent. Among the lost arts at Constantinople ab) mt this time, seems to have been the shill to sculpture capitals after the Corinthian or Ionic patterns, the plate of which was taken by clumsy inverted pyramids, quadrangular and truncated, which were used to effect a junction between the pillars and the superimposed structure.' It is possible, as sllgesested, that this devec may have been first adopted to support the rouf in the obscurity of an undergromel cistern, but it was afterwards transported to the upper an and emploged, as at st. Sophia, to complete the columns in the mont decorative enflices. In these positions it was necessary (1) abolish the crudeness of such capitals, and, as there was a purtial revival of art under fustinian, this object was ac-

1 I century or in before Jubinian, however, very fine capilals of $\mathbf{a}$

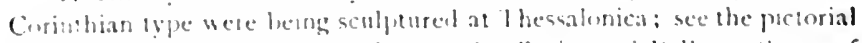

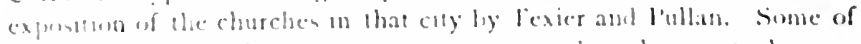

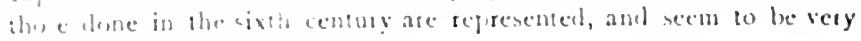

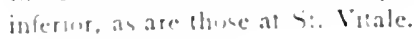

2 see P. $5 j^{n}$. 


\section{Litcrature and Art in the Sixth Century 753}

complished with some success by cutting the surface of the pyramid over with a tracery of regetable foliage, in the midst of which simple monograms were often interspersed. As such shapes are not produced in any strict conformity of outline, they are usually imitated with facility, and a measured or geonetrical treatment is, in general, satisfactory to the eye.

In the sixth decade of this century, three incidents occurred, which were of more or less importance in connection with the subject of this section. In 55 I some Asiatic monks introduced themselves to Justinian, and informed him that it was in their power to solve the difficulties which oppressed him with respect to the silk trade. Having resided long in China, they had become familiar with the method of rearing the silkworm, and they explained that if the eggs were transported to Europe they could be hatched in dung, so that a native manufacture of silk could be established. The Emperor promised to reward them liberally if they should succeed in the enterprise; and the next year they again presented themselves, furnished with a stock of the eggs, which, as some say, they had been obliged to carry away furtively concealed in hollow canes. Successful incubation followed; the worms were fed on mulberry leaves; and from this beginning dates the active propagation of the insects throughout Southern Europe, from whence nearly half the quantity of silk in commercial demand is supplied to the markets of the world. ${ }^{1}$ In 554 a severe earthquake occurred, the violence of which was chiefly operative along the Syrian coast. The city of Berytus was totally wrecked, and many persons, including numbers of law students, perished in the

${ }^{1}$ Procopius, De Bel. Goth,, iv, I7; Theophanes Byz. etc. 


\section{5t The Age of Justinian and Theodora}

ruins. The law-school was then removed to the neighbouring town of Sidon until Berytus should be rebuilt, but, although the restoration was effected satisfactorily, there is some doubt as to whether the city regained its celebrity as a centre of legal education.' Another disastrous carthequatic happened in 557 and wrought much havoc at Constantinople. One of the results of the catastrophe was that the dome of St. Sophia collapsed, hringing destruction to many of the elaborate and precious structures which occupied the floor of the church. The original architects were dead, but a younger Isidorus was entrusted with the work of reinstatement, and a new dome was constructed, having its altitude increased by twenty feet. At the re-opening a grand cercmony was enacted comparable to that which had taken place on the first occasion a score of years previously: ${ }^{2}$

It appears that the requisites for the welfare of a nation might with general consent be defined as peace al,road, and prosperity at home. We have seen that the reign of Justinian was one of incessant activity, but we fail to discern that the continuous ferment, the motive impulse of which cmanated from Constantinople, was in any way beneficial to the buman race. For nearly forty years war was almost peripheral with respect to the dominions of that Emperor; in Africa, in Italy, aggressive; on the Danube and on the Euphrates, defensive. It is possible that the lot of the Orthodox (hristians in Africa may have leen ameliorated by the expulsion of their Vandal rulers; but we are told by an eye witness that the country, which had previously been flourishing and populous, was therely reduced for hundreds

2 Agathias, ii, 15.

Hext., v, 9; Theophanes, an. 6051, elc. 


\section{Summary of the Reign}

of miles to a desert, and that as an ultimate result the Byzantine invasion might be credited with the annihilation of fully five millions of the inhabitants.' ${ }^{\prime}$ There is good reason to conclude, however, that before the time of Justinian, the religious rancour which had prevailed between the Arians and the Orthodox in the African provinces had been subdued to the level of mutual toleration, so that in the best interests of that region a continuance of the Vandal administration would have been desirable. If there be any doubt as to whether the Vandal war was really harmful to the people chiefly concerned, there can be no question but that the invasion of Italy was an unmitigated calamity for the inhabitants of that peninsula. It would be difficult to define an age, even prior to the dissolution of the Roman Republic, during which the Italians could be said to have lived in the uninterrupted enjoyment of peace and prosperity. From the foundation of Rome the peninsula was distracted for more than twelve centuries, first by ethnical and then by civil commotion, and ultimately by barbarian devastation. But for nearly forty years under the rule of Theodoric, a settlement was reached, when beneficent government without fiscal rapacity went hand in hand with religious toleration. ${ }^{2}$ It must be conceded that the successors of the founder of the Gothic monarchy were true neither to their own interests nor to those of the Italians, but the wanton warfare carried on so persistently by Justinian for nearly two decades, whilst he neglected the defence of his own dominions, was more fraught with disaster to Italy than the transient, though determined, barbarian irruptions: and we have it

1 Procopius, Anecd., I8.

2 The reign of Theodoric has been treated most fully by Hodgkin, Italy and her Invaders, Lond., I88o, etc. 


\section{The Ise of Justinian and Thiodora}

from the same authority that the depopulation of the country was even more evident to the contemporary observer than was that of Africa.'

The incapacity of the Byzantine administration to create and protect a thriving population, has been sufficiently exemplitied in the foregoing chapters, wherein we have seen the results of fiscal oppression and of ineffective preparations for repelling the Persians and harbarians. ${ }^{2} A$ glance at the course of events after the time of Justinian will complete the picture, and illustrate more fully the imbecility of the empire which that monarch attempted, but failed to consolidate. Scarcely three years had elapsed from the death of Iustinian until the Iombards imaded Italy, and in a short time the greater part of the peniusula as far south as Niples was permanently wrested from the liyzantines. It is said that this irruption was provoked by Narses himself out of revenge for his having been treated with contumely by the Byantine Court. Ite sent samples of fruits and agricultural produce to King .llboin, and comnselled him to migrate southwards with his nation in order to enjoy the fertility of Italy. But, being soon repentant, the eunuch died at Rome

l'reopiur, Anecrl., is.

- It appeas thas Jutinian liepe up an army of no more than 150,000 men, whereas for the Eastern Empire alone lwice that number al least was consilfered necesary by former rulers. Agathias, 1,13 : see p. 167.

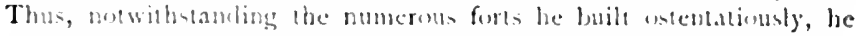
neglecledtogarsion them, lests in Europe and A in ; (Procopius, Anecd,

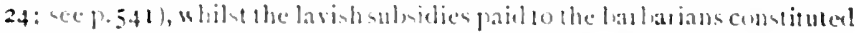
a standing invitation for the mont divtant triles te present themselves con.

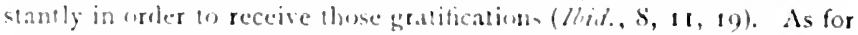

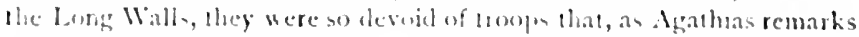
$(x, 13)$, they were not eren so well penected as a farm yarel, where at least a watch-ding's lark might le hearl.

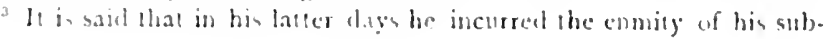


shortly afterwards at the age of ninety-five $(568){ }^{1}$ The fifty years' peace with Persia lasted only ten years, and in 572 Chosroes again crossed the Euphrates, ravaged the Roman provinces, and made himself master of Dara. Later on, however, he was successfully opposed by the Emperor Tiberius, and in 579 he died of chagrin, as it is said, at the ill success of his arms. ${ }^{2}$ But early in the seventh century Chosroes II overran Syria and Asia Minor, taking Damascus and Jerusalem, and established his camp at Chalcedon, in sight of Constantinople. About 622, however, the fortune of the Byzantines was restored by the notable campaigns of the Emperor Heraclius; and in 650 the Saracenic successors of Mohammed conquered the Persian empire. But a decade before that event, they had overthrown the Byzantine armies, and had taken permanent possession of Syria and Egypt. In the meantime the Imperial capital itself had been severely oppressed by the martial activities of the age; and between 625 and 680 had undergone several sieges by Persians, Avars, and Saracens. Such was the state of the Eastern Empire less than a century after the death of Justinian. One third of its home territory had passed into the hands of the Mohammedans, and half of the appanage of Italy into those of the Lombards. Before the year 700 the Arabs had worked their way to the extreme West, and the whole of Christian North Africa had been effaced by the

ordinates through parsimony, whence they petitioned for his recall. On his refusal to retum to the capital in obedience to a mandate, Sophia taunted him by writing, "Come and take up your proper place among the handmaids who ply the distaff in the women's apartments," to which he replied, "I will find a yarn for her to spin which she will not be able to get through in her lifetime"; Paulus Diac., Hist. Miscell., xviii, etc.

1 Agnellus, Lib. Pontif, Agnellus, Peter Sen.

2 Agathias, iv, 29. 


\section{$75^{\mathrm{S}}$ The Age of Iustinian and Thodora}

rotaries of Islam. If the Vandal kingdon had been left undisturbed, there is no reason to suppose that it could have withstood the conquering fanatics who were inspired by the Ipostle of Mecca; although the existence of a flourishing Hestern civilization for more than seven hundred years be. tween the Red Sea and the lilantic proves that states of the highest European type might be permanently established in those latitudes. The subject need not be pursued into further detail; the samples given illustrate sufficiently how the Greeo-koman power became progressively dilapidated, with occasional intervals of better fortune, until in the fifteenth century the Byzantine Empire became synonymous with the area circumscribed by the walls of Constantinople. In 4453 the city was taken by the lurks, and the fact announced to Christendom that civilization and progress in the modern sense had become extinct in three-fourths of the countries which lie around the basin of the Mediterrancan.'

Shortly after his accession we find Justin II reprobating in the old strain the rapacity of the Rectors, ${ }^{2}$ deploring the fact that they buy instead of earning their appointments as

1 The history of the Empire up lo the fall of Comstantinnple, has been narrated by Gibbon, and at greated lengh ly linlay. "The fullest accome "f the siege is that of l'ears, I.und., I 896.

- Noveclxi. At all limes and places the liyzantine system was so oppressive, that cren the Abasgi and Tani, who were supposed ho have found salvation in Chriviandy (pp. 700, 702), resolted to the l'ersiansand

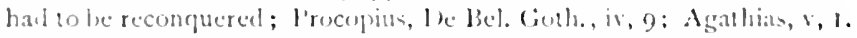
Nolwhlobanding his koman experience, his having lendeved his chas. acter at l'etra, and his age, Bessas al once entered om another camplaign

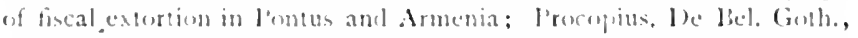
iv, 13. Justin also, the son of fiermante, conntemanced a sulurblinate in harrying the farmers for miluay seores which they coubl nut supply,

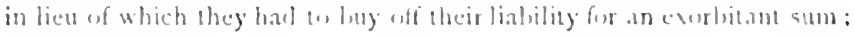
Agallias, is, 22 . 
the reward of having proved their capacity, and reiterating the futile injunction that they are to delay their departure from the provinces for fifty days after laying down their office. In the exordium to this Constitution he characterizes in a pregnant allusion the administration of his predecessor, and may be said to pronounce the epitaph of Justinian :

"The mere promulgation of admirable laws is not THE SOLE ESSEntial in a STATE, bUt the ENaCtMents MUST BE ZEALOUSLY MAINTAINED AND ENFORCED, WHILST DELINQUENTS ARE SUBJECTED TO CONDIGN PUNISHMENT. FOR WHAT CAN BE THE UTILITY OF LAWS WHICH APPEAR ONLY ON PAPER, AND ARE NOT RENDERED BENEFICENT TO THE SUBJECT BY BEING PRACTICALLY APPLIED?"

THE END 


\section{N DEX}

ABASGI, conversion of, 702 ; revolt of, 75 .

Achaemenian dynasty of Persia, 373.

Africans, character of, 496.

Agapetus, Pope, at CP., $67 \mathrm{I}$.

Agathias, historian, his writings, 748 .

Agnates, relatives by males, 715 .

Alamundar, Arab sheikh, invades Syria, 404 .

Alexander the "Scissors," 624.

Amalasuntha, Gothic Queen, 546; her death, 550, 6 I I.

Ancona, naval battle of, 646 .

Anthemius, architect, 529.

Anthimus, Monophysite Patriarch, 670.

Antioch, 587 ; capture of, 590 .

Antonina, wife of Belisarius, her infidelities and intrigues, 605, 6II, 673; her death, 74I.

Arab conquests, 757 .

Archaeopolis, siege of, 728 .

Ardeshir, founder of later Persian Empire, 373.

Arethas, Arab sheikh, 407, 594, $6 S 8$.

Ariminum, betrayal of, 572 ; siege of, 574 ; battle at, 652 .

Aristotle, philosopher, 421.
Arsacid or Parthian dynasty of Persia, 37 I, 373.

Artabanes, a general, in Africa, 522 ; in Armenia, 585 ; at CP., 621 ; in Sicily, 646; in Italy, 662.

Avars, embassy from, 735 . Avesta, the Persian Bible, 376 .

Barbarians, assaults of on Empire, $417,734,736$.

Belisarius, his campaigns against Persia, 397, 593, 596; in Africa, 505; his triumph, 515 ; in Italy, 550,630 ; at Ravenna, 5So; characterization of, $580,5 \mathrm{~S} 2$; in disgrace, 618, 740; letters of, 631,641 ; last campaign, 738 ; his death, 741 .

Berytus, law school at, 724 ; ruin of, 753 .

Bessas, a general, in Armenia, 413; at Petra, 6or; at Rome, 634,637 ; his avarice, $i 6 ., 758$. Boethius, statesman and author, 546, 749 .

Bosporus, revolt of, $70 \mathrm{r}$.

Butilin and Leuthar, Frankish generals, invade Italy, 66I ; their death, $66_{3}, 66_{4}$. 


\section{The Age of Justinian and Theodora}

Callinicus, battle of, 407 : taking of, 597 .

Carthage, topograplyy of, +93 .

Casilinum, battle of, 66.4 .

Casiodorus, statesman and author, $5+6,7+9$.

Cavades, Persian king, his death, 41.4 .

Chostoantioch, 591 .

Chosroes, Persian king, his accession, 415: his character and studies, 435, 4S.4; in Lazica, 594, 607: his death, 757 .

Circus factions, affectations of, 453.

Cisterns at CP., 539.

Code of Justinian, 721 .

Comit $\mathrm{O}_{2}$ sister of Theodora, $4 \mathrm{O}_{3}$.

Constantine, a general, 56.4, 567; his death, 606.

Corippus, poet, 526, 743.

Council, Fifth Oecumenical, $68_{4}$, sog.

Cesipton, larthian capital of I'ersin, 374 .

Cumac, siege of, 659 ; surrender of, 662 .

Cyrus, the Achaemenian, founder of l'ersian Empire, 371.

Ingisthacus, a general, parallel letween and liessas, 65S.

Dara, battle of, 397; fortificativons of, $5 .+2$.

Debtors, new laws in favour of, 712.

Decinum, hattle of, 507 .

bigest or l'andects, 722.

Divorec, laws respecting, 719 .
Elessa, siege of, 59 S.

Eleshaas, Negus, cmbassy to, 410 .

Epicurus, philosopher, 423 .

Forte, liyzantine, 542 .

Gelimer, Vanelal king, 501; his capture, 514: at CP., 516.

Genseric, Vandal king, 499.

Germanus, nepliew of Justinian, in Africa, 520: at Antioch, 5 SS; his death, 646 .

Gontharis, revolt of, 521 .

Gubazes, Lazic king, revolts to Persia, 59.4; his murder, 731; trial respecting, 732 .

Hadrian, Emperor, Mausoleum of, 557, 567; his Perpetual Edict, 716.

Ileriaion, palace of, 365 .

II merites or Ilimyarites, fio.

IJuns, irruptions of, $412,648,736$.

llypatius and lompeius, usurpers, $460,5 \%$.

Inheritance, laws as to, 715, sig.

Institutes of Justinian, 723 .

Interest an money lent, II $_{3}$.

Iran, native name of Persia, 373 .

Inligrumas, I'ervian amlassador, $600,726$.

Isidorts, architect, 529, 754.

Istaklur, eapital of l'er-is, 373 .

Jacol, Baralaeus, apostle of Mono. physites, 658.

lews, treatment of, $69 \$$.

John, nephew of Vitalian, ageneral, in Italy, 571, 572, 574, 651, 660. 


\section{Index}

John of Cappadocia, a financier, 444; his carousing, 447; his fall, 613: his return, 735 .

John of Ephesus, bishop, 699 .

John, son of Theodora, 62I.

John the Armenian, 506, 51 1 ; his death, 5 I 2.

John Troglita, a general, 526 .

Justin, a general, in Lazica, 728,

735 .

Justin II, Emperor, his accession 742.

Justinian, Emperor, personal appearance and character, 365 ; suppresses revolt, 467 ; his clerical laws, 6S9; his persecu. tions, 692 ; his theological works, 702 ; his legislation, 709, s7\%.; his death, 742 .

Krêtuk-das, Persian marriage custom, 382 .

Lazica, war in, 594, 600, 608, 727. Leuthar. See Butilin.

Literature, Persian, 395; Byzantine, 744 .

Lombards invade Italy, $75^{6}$.

Martin, a general, in Lazica, 729 , 733.

Martyropolis, siege of, $4 \mathbf{I} 2$.

Mashita palace, 394.

Matasuentha, wife of Vitigis, 564 ; her treacheries, 572, $58 \mathrm{So}$; marries Germanus, 623 .

Maximian, bishop, 750 .

Mazdak, Persian heretic, 386 .

Mazdeism, Persian religion, 376.

Melchites, 689.
Milan, surrender of, 573; recapture of, 575 .

Moors, their method of warfare, 524 .

Mundus, a general, 419; at CP., 467 ; his death, $55^{1}$.

Naples, sieges of, 552, 626 .

Narses, eunuch general, at CP., 467 ; in Italy, 574, 648, sqq. : takes Rome, $65^{8}$; at Casilinum, 664 ; at Alexandria, 676 ; his death, 756 .

Negus of Axum, embassy to, 410. Neoplatonists in Persia, $434 \mathrm{sq}$.

Neoplatonism and Christianity, $43^{8}$.

Nika rerolt, 459 .

Novels of Justinian, 725 .

Odovacar, barbarian king in Italy, 545 .

Origen, Egyptian Father, 677, 701.

Ormuzd and Ahriman, 376 .

Pandects. See Digest.

Patria potestas, $7 \mathrm{I} 3$.

Patricians, 90, 714 .

Parthians, the, $37 \mathrm{I}$.

Peace, Perpetual, 416.

Pelagins, Pope, at Rone, 633, 639 ; at $\mathrm{CP} ., 677$; in Italy, 686.

Perpetual Edict, 7 I6.

Persians, sociology of, 374 sqq.

Persis, home of Persian race, 372.

Peter Magister, ambassartor in Italy, 540; in Persia, 726, 740. Petra, sieges of, 594, 60I. Phasis, siege of, 728 . 


\section{6+ The Age of Justinian and Thiodora}

Philosepplers, female, $42 S$.

lhilosophy, Greck, virious sects of, $421,5 y$.

lhotius, sun of Antonina, 607, 610 : his death, 741 .

Plague in the liast, 6oz.

rlato, philwopler, 421.

I'raceste, Eilict of. 716.

J'rasmatic Sianction, $66_{5}$.

P'roclus, Neoplatonist, 427.

l'rocopius, histurian, 503, 57S;

his writings, 744 .

Yueer occurrences, $3 S_{2}, 575,735$, 750 .

kavenna, mosaics at, 366,367 , 750 : sjeges of, $545,57 \mathrm{~s}$.

Rectors, retorms renpecting, 472 .

kome, topegraphy of, 555; sociolong ot, $55^{\text {ti: }}$ sicuges of, 566 , $630,642,0.43,65 \mathrm{~s}$.

Si. Silin at Cl'., 606 .

st. Suplaia, church of, dilapilation of. 754 .

Salviu, Julianm, lawyer, 716.

samaritals. rewolt uf, 695.

Sandichl, Ilumniah lemler, 739.

Samatian dynasty of l'ersia, 373.

Silk trale, \& I I, 4S3.

Silkworm imponted into Europe, $75 j$.

sibcrius, l'ope, 554, 569; his depensition and death, 612,67.; sillan, a gencral, 403 , 7wo; his death, 555 .

slasen, new laws in fatsure of, 708 .

Slav, mruptum of, 734.

sucrates, piniliserplere, 420.
Spain, Byzantines in, 526.

Stotzas, revolt of, $51 \$$.

Syce, Thcodora's momastery at, 676.

Taginae, lnttle of, 654 .

Taves, oppressive, 445, 4Si ; in Persia, 391.

Tera, Guthicgeneral, 650; elected king, 657; his leath, 660 .

Therdahad, Guthic king, 547, 550: his diath, 554 .

Theodebald, Jankish king, 659 .

Theodelert, Frankish king, 576 , $573,645,746$.

Theolora, Empress, persomal appearance and character, 367: combluce during revolt, 406 ; her intrigutes, 609 : letters of, 608 , 619: her relisiums pulicy, 669, syt. ; her death, 6.43, 659 .

Theodere Ancilas, hishop, 677. $6 \$ 7$.

Theodoric, Gothic king, 54t, 75.5.

Three Chapters, contruversy of, $6 ; 5,5 \%$.

Ticinum, the (ioths at, 657,650.

Tutila or liaducla, Ginthic king, hi, accession. 625; at Naples, 026: at kume, 629, 643; at laginac, 652: his death, 656.

Trajan, Emperur, his compuests, 371.

Tribmian, a lawger, 4.42; his lengil work, 720.

Tricancrum, latule of, 510 .

Trimm at Cl'., 515.

Teani, combersiun of, 700 ; their icvolt, 758 . 


\section{$\operatorname{Index}$}

Uranius, charlatan, 436 .

Usdrilas, Gothic general, $65 \mathrm{I}$.

Vandals, their character, 500.

Vigilius, Pope, in Sicily, 632; at Rome, 68o; at CP., 68I, squ.; his death, 686 .

Vitigis, Gothic king, 553; at Rome, 566, sqq.; capture of, $58 \mathrm{I}$; his death, 623 .
Walls, Long, $543,737,756$.

Xenophon, his description of Syrian desert, 405.

Yemen, Christianity in, 409.

Zabergan, Hunnish leader, $73^{6}$.

Zend, language, 376 .

Zeno of Citium, philosopher, 422. Zoroaster or Zarathushtra, 376 . 


\section{ADDITIONS}

P. 595. After Lazica. read, Gubazes, the King, met and alored the Slah on his arrival.

1'.612. After coull desire, read, he should wear the rolie of Augustus, etc.

P. 731 . Read, Byzantine Court.'

1 Procopius, Ie Bel. Pers, ii. 29. Arrears of pay for ten years seem to have been owing to him for this service.

P. 73.t. After unforeseen attack, rearl, a nemesis approved of ly the historian who relates the occurrence. 
CHISWICK VRESS: CHARLES WHITTINGHAM AND CO. THOK- COURT, CHANCERY I.ANE, LONDON. 




ST. MICHAEL'S COLLEGE LIBRARY

$$
\text { Nov }-819
$$

DATE DUE:

CALL NUMBER

AUTHOR

Hntine, illizam.

DF

572

The age of Justinian

. $\mathrm{H} 7$

$\mathrm{v} \cdot 2$

and Theodora. 


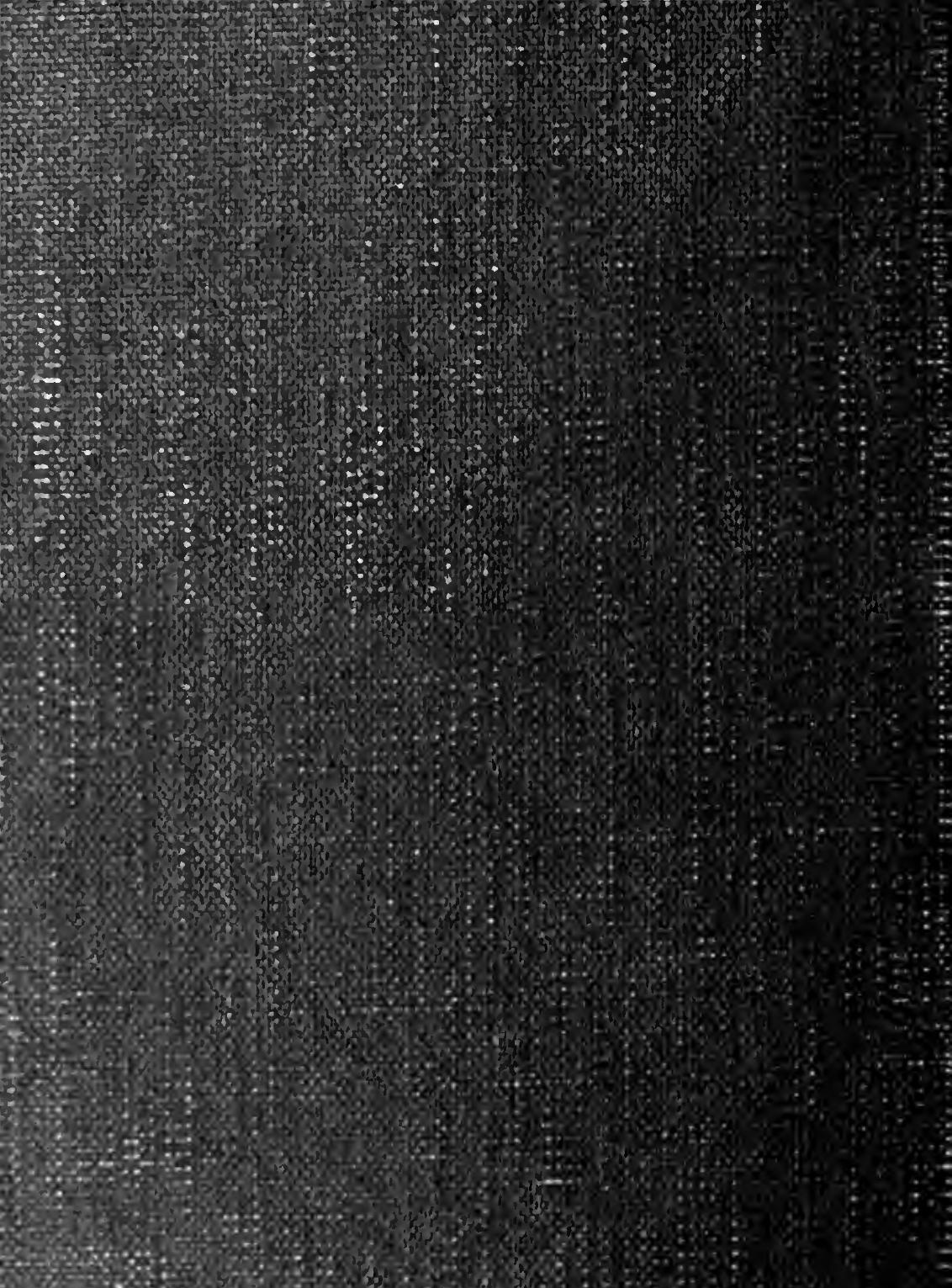

